CYNARA BALTAZAR BARBOSA

\title{
MICOFLORA E OCORRÊNCIA DE MICOTOXINAS EM GRÃOS DE TRIGO RECÉM-COLHIDOS E ARMAZENADOS
}

Dissertação apresentada ao Programa de PósGraduação em Microbiologia do Instituto de Ciências Biomédicas da Universidade de São Paulo, para obtenção do Título de Mestre em Ciências. 
CYNARA BALTAZAR BARBOSA

\section{MICOFLORA E OCORRÊNCIA DE MICOTOXINAS EM GRÃOS DE TRIGO RECÉM-COLHIDOS E ARMAZENADOS}

Dissertação apresentada ao Programa de PósGraduação em Microbiologia do Instituto de Ciências Biomédicas da Universidade de São Paulo, para obtenção do Título de Mestre em Ciências.

Área de Concentração: Micotoxinas

Orientador: Prof. Dr. Benedito Corrêa

Versão original 
DADOS DE CATALOGAÇÃO NA PUBLICAÇÃO (CIP)

Serviço de Biblioteca e Informação Biomédica do

Instituto de Ciências Biomédicas da Universidade de São Paulo

reprodução não autorizada pelo autor

\section{Barbosa, Cynara Baltazar}

Micoflora e ocorrência de micotoxinas em grãos de trigo recémcolhidos e armazenados / Cynara Baltazar Barbosa. -- São Paulo, 2014

Orientador: Prof. Dr. Benedito Corrêa.

Dissertação (Mestrado) - Universidade de São Paulo. Instituto de Ciências Biomédicas. Departamento de Microbiologia. Area de concentração: Microbiologia. Linha de pesquisa: Morfofisiologia dos fungos, fungos toxigênicos e micotoxinas.

Versão do título para o inglês: Mycoflora and ocurrence of mycotoxins in grains of wheat freshly harvested and stored.

1. Fusarium spp. 2. Alternaria spp. 3. Trigo 4. Deoxinivalenol 5 Zearalenona 6. LC-MS/MS I. Corrêa, Prof. Dr. Benedito II Universidade de São Paulo. Instituto de Ciências Biomédicas. Programa de Pós-Graduação em Microbiologia III. Título. 
UNIVERSIDADE DE SÃO PAULO

INSTITUTO DE CIÊNCIAS BIOMÉDICAS

\begin{abstract}
Candidato(a): $\quad$ Cynara Baltazar Barbosa.
Título da Micoflora e ocorrência de micotoxinas em grãos de trigo recém-colhidos e armazenados.
\end{abstract}

Orientador(a): $\quad$ Prof. Dr. Benedito Corrêa.

A Comissão Julgadora dos trabalhos de Defesa da Dissertação de Mestrado, em sessão pública realizada a ..............................., considerou

( ) Aprovado(a) ( ) Reprovado(a)

\begin{tabular}{|c|c|}
\hline Examinador(a): & $\begin{array}{l}\text { Assinatura: } \\
\text { Nome: ........ } \\
\text { Instituição: }\end{array}$ \\
\hline Examinador(a): & $\begin{array}{l}\text { Assinatura: } \\
\text { Nome: } \\
\text { Instituiç̧ão: }\end{array}$ \\
\hline Presidente: & $\begin{array}{l}\text { Assinatura: } \\
\text { Nome: ........ } \\
\text { Instituicão: }\end{array}$ \\
\hline
\end{tabular}




\section{CERTIFICADO DE ISENÇÃO}

Certificamos que o Protocolo CEP-ICB No 477/11 referente ao projeto intitulado: "Micoflora e análise de deoxinivalenol em amostras de trigo em diferentes etapas do cultivo" sob a responsabilidade de Cynara Baltazar Barbosa, foi analisado na presente data pela CEUA COMISSÃO DE ÉTICA NO USO DE ANIMAIS e pela CEPSH- COMISSÃO DE ÉTICA EM PESQUISA COM SERES HUMANOS, tendo sido deliberado que o referido projeto não utilizará animais que estejam sob a égide da lei 11.794 de 8 de outubro de 2008, nem envolverá procedimentos regulados pela Resolução CONEP nº196 de 1996.

São Paulo, 17 de agosto de 2011.

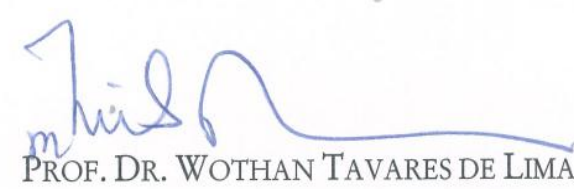

Coordenador da CEUA - ICB/USP

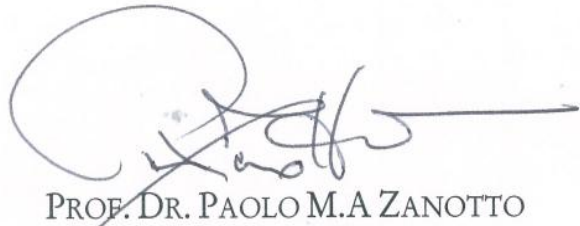

Coordenador da CEPsh - ICB/USP 
A parte experimental deste trabalho foi executada nos laboratórios de Microbiologia e Micotoxinas do Instituto de Ciências Biomédicas da Universidade de São Paulo (USP) e no Laboratório de Análises Micotoxicológicas da Universidade Federal de Santa Maria. 
Ao meu "Papai do Céu", que me ilumina, abençoa E se faz sempre presente em minha vida.

À minha mãe e aos meus pais Que sempre me incentivaram na realização de meus ideais Encorajando-me a enfrentar e superar os momentos dificeis da vida Pela presença, paciência, compreensão, confiança e contribuição Para a realização de mais esta conquista Com o maior amor do mundo Dedico-lhes este trabalho. 


\section{AGRADECIMENTOS}

Ao Prof. Dr. Benedito Corrêa, pela orientação, apoio, incentivo e paciência. Obrigada pelos ensinamentos, conselhos e experiências compartilhadas.

Aos professores do Departamento de Microbiologia e à Universidade de São Paulo pelos conhecimentos adquiridos.

Às amigas Lívia Fontes, Gabriela Reis e Liliana Rocha pelo companheirismo, auxílio e conselhos de sempre e pela grande e verdadeira amizade.

À Sabina Tralamazza, Raquel Braghini, Marcia Salvadori, Vinícius Barroso, Rodrigo Oliveira e Tainah Drumond por todo auxílio, aprendizado e convívio no laboratório.

À Tatiana Alves dos Reis, pelo apoio técnico durante todo o experimento, e também pela atenção e compreensão.

À Gisele da Graça Santana e Elizabete dos Santos Ribeiro, secretárias do Departamento de Microbiologia, pelos esclarecimentos, paciência e atenção.

Ao Edilson de Oliveira Bernardino, pela disposição, atenção e pelo auxílio na pesquisa de trabalhos científicos.

À Profa. Dra. Maria Helena Iha, pelos ensinamentos, direcionamento, incentivo, apoio e amizade em todos esses anos.

Ao João Felício do Instituto Agronômico de Campinas, que dedicou esforços para a coleta das amostras de grãos de trigo de Capão Bonito e auxílio na pesquisa.

Ao Vilson de Vechi, Rubens Yamanaka e Ludmila Lajarin do Núcleo de Produção de Sementes de Avaré (CATI), que dedicaram esforços para o envio das amostras de grãos de trigo. 
À Fernanda Dambrós, Luciane Minetto e ao Tibiriçá Vasconcelos, pelos ensinamentos, disposição, carinho e assistência técnica nas análises de LC-MS/MS.

Ao Prof. Dr. Carlos Malmann e ao Prof. Dr. Paulo Dilkin, por permitirem o uso do equipamento LC-MS/MS e pela recepção, atenção e carinho durante minha experiência no LAMIC.

Aos Professores da banca examinadora, pela atenção dispensada na correção desta dissertação.

Ao Marcio Romera Araujo pelo apoio, auxílio, compreensão, companheirismo e carinho.

A todos os meus amigos e familiares, pelos momentos de alegria, incentivo, companheirismo e amor dedicados a mim.

À Coordenação de Aperfeiçoamento de Pessoal de Nível Superior (CAPES) pelo auxílio financeiro durante a pesquisa.

E a todas as pessoas que, de alguma forma, contribuíram para a realização deste estudo, e também para o meu aprendizado. 


\section{RESUMO}

BARBOSA, C. B. Micoflora e ocorrência de micotoxinas em grãos de trigo recémcolhidos e armazenados. 2014. 138 f. Dissertação (Mestrado em Microbiologia) - Instituto de Ciências Biomédicas, Universidade de São Paulo, São Paulo, 2014.

O presente trabalho objetivou avaliar mensalmente, por um período de sete meses, a microbiota fúngica e a ocorrência de micotoxinas (deoxinivalenol (DON), zearalenona (ZEA) e alternariol $(\mathrm{AOH}))$ em amostras de trigo recém-colhidas e armazenadas, provenientes de duas regiões produtoras localizadas no Sudoeste do Estado de São Paulo, Brasil, Capão Bonito e Avaré. A avaliação dos fatores abióticos, atividade de água e fatores climatológicos das regiões de cultivo, também constituiu objetivo do estudo. $\mathrm{O}$ isolamento dos fungos foi realizado pela técnica da semeadura direta, utilizando meio de cultura DRBC (Ágar Dicloran Rosa Bengala Cloranfenicol) e DG 18 (Ágar Dicloran Glicerol). Os fungos foram identificados em nível de gênero, entretanto, aqueles pertencentes aos gêneros Fusarium e Alternaria foram identificados até espécie, utilizando métodos morfológicos clássicos (macro e micromorfológicos) e moleculares (sequenciamento parcial do gene TEF-1 $\alpha$ e gene Alt a 1, respectivamente). As análises micotoxicológicas foram realizadas utilizando Cromatografia Líquida de Alta Eficiência acoplada à Espectrometria de Massas Sequencial (LC-MS/MS), coluna de fase reversa $\mathrm{C}-8$, ionização por eletrospray em modo positivo e eluição por gradiente. Os resultados revelaram a predominância do gênero Alternaria nas amostras de todas as coletas, seguido de Epicoccum $(12,6 \%)$, Fusarium $(8,3 \%)$ e mais 16 outros gêneros de fungos filamentosos: Phoma (6,3\%), Cladosporium (4,9\%), Drechslera (3,7\%), Nigrospora (1,5\%), Aspergillus (1,4\%), Bipolaris (1,2\%), Penicillium (1,0\%), Acremonium (0,27\%), Pyrenophora (0,22\%), Mucor (0,13\%), Curvularia (0,1\%), Helminthosporium (0,09\%), Monographella (0,05\%), Rhizopus $(0,04 \%)$, Phomopsis $(0,03 \%)$ e Chaetomonium (0,02\%). A atividade de água média nas amostras variou de 0,75 a 0,53 e, assim como o crescimento fúngico, diminuíram com o tempo de armazenamento. $F$. graminearum e A. alternata foram as espécies mais frequentes dentre os respectivos gêneros. Das 70 amostras de Capão Bonito, 69 (98,6\%) estavam contaminadas com DON (210-2910 $\mathrm{ug} / \mathrm{kg})$ e $3(4,3 \%)$ amostras com ZEA $(20-30,1 \mu \mathrm{g} / \mathrm{kg})$. Quanto ao $\mathrm{AOH}$, as amostras não apresentaram qualquer contaminação. As amostras de Avaré não apresentaram contaminação pelas toxinas de Fusarium spp. e Alternaria spp. em estudo, o que pode ser justificado pelo prévio processo de beneficiamento ao qual foram submetidas. O nível de contaminação por DON são inferiores aos limites estabelecidos recentemente pela legislação brasileira (3000 $\mu \mathrm{g} / \mathrm{kg}$ ), porém superam os limites legais definidos pela Comunidade Européia (1750 $\mu \mathrm{g} / \mathrm{kg})$, o que demonstra a necessidade de maior controle e fiscalização dos alimentos, visando conhecer a extensão dessa contaminação e fornecer informações importantes, escassas em nosso país, para os diversos segmentos envolvidos com a produção, utilização e comercialização de trigo bem como para fiscalização e pesquisa, a fim de garantir ao consumidor final produtos de melhor qualidade.

Palavras-chave: Fusarium spp. Alternaria spp. Micobiota. Trigo. Deoxinivalenol. Zearalenona. Alternariol. LC-MS/MS. 


\begin{abstract}
BARBOSA, C. B. Mycoflora and occurrence of mycotoxins in grains of wheat freshly harvested and stored. 2014. 138 p. Masters thesis (Microbiology) - Instituto de Ciências Biomédicas, Universidade de São Paulo, São Paulo, 2014.

The present study aimed to evaluated the mycoflora and occurrence of mycotoxins (deoxynivalenol (DON), zearalenone (ZEA) and alternariol (AOH)) in freshly harvested and stored wheat samples from two producing regions in the southwest of the state of São Paulo, Brazil, Capão Bonito e Avaré. The samples were examined monthly over a period of seven months. Abiotic factors, water activity and climatological growing regions also constituted the study objective.The isolation of fungi was performed by direct plating technique using agar medium DRBC (dicholoran Rose Bengal Chloramphenicol) and DG 18 (dicholoran Glycerol) . The fungi were identified at genus, however, the genera Fusarium and Alternaria were identified to species using classics morphological methods (macro and micromorphological) and molecular (partial sequencing of the gene TEF-1 $\alpha$ gene and the Alt a 1, respectively). Mycotoxicological analyzes were performed using high performance liquid chromatography coupled to tandem mass spectrometry (LC-MS/MS), reverse phase column C-8, electrospray ionization in the positive mode and gradient elution. The results showed the predominance of Alternaria in all samples, followed by Epicoccum (12.6\%), Fusarium $(8.3 \%)$ and over 16 other genera of filamentous fungi: Phoma (6.3\%), Cladosporium (4.9\%), Drechslera (3.7\%), Nigrospora (1.5\%), Aspergillus (1.4\%), Bipolaris (1.2\%), Penicillium (1.0\%), Acremonium (0.27\%), Pyrenophora (0.22\%), Mucor $(0.13 \%)$, Curvularia $(0.1 \%)$, Helminthosporium (0.09\%), Monographella (0.05\%), Rhizopus (0.04\%), Phomopsis $(0.03 \%)$ and Chaetomonium $(0.02 \%)$. The average water activity in the samples ranged from 0.75 to 0.53 and as well as fungal growth, decreased with storage time. $F$. graminearum and $A$. alternata were the most frequentspecies from the respective genus. Of the 70 samples from Capão Bonito region, 69 (98.6\%) were contaminated with DON (210 to $2910 \mathrm{ug} / \mathrm{kg}$ ) and 3 (4.3\%) samples with ZEA (20 to $30.1 \mathrm{ug} / \mathrm{kg}$ ). Regarding $\mathrm{AOH}$, samples showed no contamination. Due to prior beneficiation process, samples from Avaré were not contaminated by any of the studied Fusarium spp. and Alternaria spp. toxins. DON levels were lower than the established limitof Brazilian legislation $(3000 \mu \mathrm{g} / \mathrm{kg})$, but exceed the legal limits set by the European Community $(1750 \mu \mathrm{g} / \mathrm{kg})$, which demonstrates the need for greater control and supervision, in order to determine the extent of contamination and provide important information, scarce in our country, for wheat production and marketing segments as well as for monitoring and research, to ensure better quality products for consumers.
\end{abstract}

Keywords: Fusarium spp. Alternaria spp. Mycoflora. Wheat. Deoxynivalenol. Zearalenone. Alternariol. LC-MS/MS. 


\section{LISTA DE GRÁFICOS}

GrÁFICO 1- FREQUÊNCIA RELATIVA (\%) DE ISOLAMENTO DOS DIFERENTES FUNGOS DE GRÃOS DE TRIGO RECÉM-COLHIDOS EM CAPÃO BONITO E AVARÉ. 75

GrÁFICO 2 - FREQUÊNCIA RELATIVA (\%) DE ISOLAMENTO DOS DIFERENTES FUNGOS DE GRÃOS DE TRIGO APÓS O $1^{\circ}$ MÊS DE ARMAZENAMENTO EM CAPÃO BONITO E AVARÉ...... 75

GRÁFICO 3 - FREQUÊNCIA RELATIVA (\%) DE ISOLAMENTO DOS DIFERENTES FUNGOS DE GRÃOS DE TRIGO APÓS O $2^{\circ}$ MÊS DE ARMAZENAMENTO EM CAPÃo Bonito E AVARÉ...... 76

GRÁFICO 4 - FREQUÊNCIA RELATIVA (\%) DE ISOLAMENTO DOS DIFERENTES FUNGOS DE GRÃOS DE TRIGO APÓS O $3^{\circ}$ MÊS DE ARMAZENAMENTO EM CAPÃo Bonito E AVARÉ...... 76

GRÁFICO 5 - FREQUÊNCIA RELATIVA (\%) DE ISOLAMENTO DOS DIFERENTES FUNGOS DE GRÃOS DE TRIGO APÓS O $4^{\circ}$ MÊS DE ARMAZENAMENTO EM CAPÃo Bonito E AVARÉ...... 77

GRÁFICO 6 - FREQUÊNCIA RELATIVA (\%) DE ISOLAMENTO DOS DIFERENTES FUNGOS DE GRÃOS DE TRIGO APÓS O 5 MÊS DE ARMAZENAMENTO EM CAPÃO BONITO E AVARÉ.......77

GrÁFICO 7 - FREQUÊNCIA RELATIVA (\%) DE ISOLAMENTO DOS DIFERENTES FUNGOS DE GRÃOS DE TRIGO APÓS O $6^{\circ}$ MÊS DE ARMAZENAMENTO EM CAPÃo Bonito E AvarÉ...... 78

Gráfico 8 - FREQuÊnCIA RELATIVA (\%) DE ISOLAMENTO DAS DIFERENTES ESPÉCIES DE FUSARIUM EM CAPÃO BONITO.

Gráfico 9 - FrequênCIA RELATIVA (\%) DE ISOlAMENTO DAS DIFERENTES ESPÉCIES DE FUSARIUM EM AVARÉ. 80

Gráfico 10 - FREQUÊNCIA RELATIVA (\%) DE ISOLAMENTO DE FUSARIUM SPP. NAS REGIÕES DE ESTUDO.

GRÁFICO 11 - FREQUÊNCIA RELATIVA (\%) DE ISOLAMENTO DE FUSARIUM SPP. NOS DIFERENTES MEIOS DE CULTURA, NAS AMOSTRAS DE CAPÃO BONITO.

GrÁFICO 12 - FREQUÊNCIA RELATIVA (\%) DE ISOLAMENTO DE FUSARIUM SPP. NOS DIFERENTES MEIOS DE CULTURA, NAS AMOSTRAS DE AVARÉ. 82

GrÁFICO 13 - FREQUÊNCIA RELATIVA (\%) DE ISOLAMENTO DAS DIFERENTES ESPÉCIES DE ALTERNARIA EM CAPÃO BONITO 84

Gráfico 14 - FrequênCIA RELATIVA (\%) DE ISOLAMENTO DAS DIFERENTES ESPÉCIES DE ALTERNARIA EM AVARÉ.

GrÁFICO 15 - FREQUÊNCIA RELATIVA (\%) DE ISOLAMENTO DE ALTERNARIA SPP. NAS REGIÕES DE ESTUDO

Gráfico 16 - FrequênCIA RElativa (\%) DE isOlamento DE ALternaRia SPP. NOS DIFERENTES MEIOS DE CULTURA, NAS AMOSTRAS DE CAPÃO BONITO. 86 
Gráfico 17 - FrequênCIA RElativa (\%) DE ISOLAMENTO DE ALternaria SPP. NOS DIFERENTES MEIOS DE CULTURA, NAS AMOSTRAS DE AVARÉ........................86

GráfiCo 18 - RELAÇÃO ENTRE A ATIVIDADE DE ÁGUA E A CONTAMINAÇÃO POR FUSARIUM SPP. E ALTERNARIA SPP. NAS AMOSTRAS DE CAPÃO BONITO. .................................. 90

GrÁfico 19 - RELAÇÃo ENTRE A ATIVIDADE DE ÁGUA E A CONTAMINAÇÃO POR FUSARIUM SPP. E ALTERNARIA SPP. NAS AMOSTRAS DE AVARÉ.................................................90

GrÁFICO 20 - DADOS METEREOLÓGICOS NORMALIZADOS DA REGIÃO DE CAPÃO BONITO. ....... 91

GrÁFICO 21 - DAdOS METEREOLÓGICOS NORMALIZADOS DA REGIÃO DE AVARÉ. ....................91 


\section{LISTA DE FIGURAS}

Figura 1 - SeÇões Longitudinal e Transversal de um Grão de Trigo.......................... 24

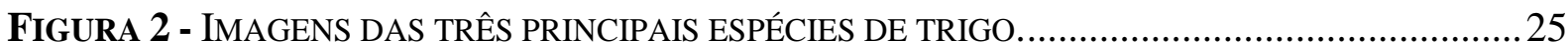

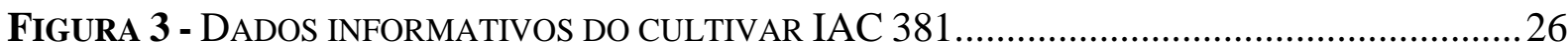

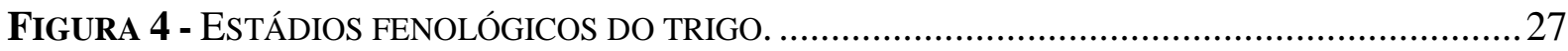

Figura 5 - Macroconídios (SETA acima), fiálides (SETA no CENTRO) E ESPOROdóQuio (SETA ABAIXO) DE FUSARIUM GRAMINEARUM. ..................................................... 31

Figura 6 - (A) SEÇÃo transversal dE um PERITÉCio DE GibBERELla ZEAE APRESENTANDo OSTÍOLO (SETA ACIMA) E ASCAS COM ASCÓSPOROS (SETA ABAIXO). (B) ASCÓSPOROS DE GibBERElla ZEAE SÃO LEVEMENTE CURVAdOS E COM AS EXTREMIDADES ARREDONDADAS. 33

FigurA 7 - CONÍDIOS DE ALTERNARIA ALTERNATA. 35

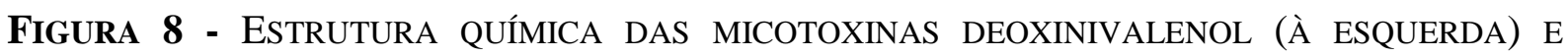

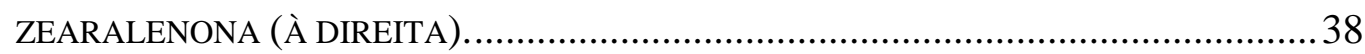

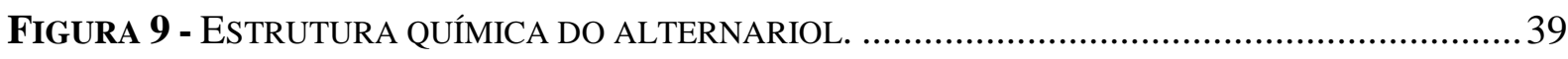

FigURA 10 - ILUSTRAÇÃO DO FUNDAMENTO DA ESPECTROMETRIA DE MASSAS....................... 46

FIGURA 11 - ESQUEMA ILUSTRATIVO DO FUNCIONAMENTO DE UM ESPECTRÔMETRO DE MASSAS. 48

Figura 12 - Mapa do Estado de São Paulo, identificAndo os Municípios onde foram REALIZADOS OS EXPERIMENTOS. 57

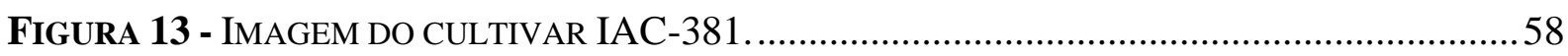

FIGURA 14 - “BAGS” ONDE FORAM ARMAZENADOS OS GRÃOS DE TRIGO. ................................58

Figura 15 - SEMEADURA DIRETA PARA O ISOLAMENTO DA MICOBIOTA FÚNGICA NOS GRÃOS DE TRIGO EM MEIO DRBC (ACIMA) E EM MEIO DG 18 (ABAIXO)..............................60

Figura 16 - ColÔNIAS DE FUNGOS FILAMENTOSOS ISOLADAS DE GRÃOS DE TRIGO, EM MEIOS

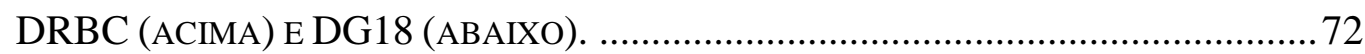

FigURA 17 - CROMATOGRAMA E ESPECTRO DE PADRÕES DE DON E ZEA................................ 92

Figura 18 - Pico CROMATOGRÁFICO REFERENTE À ELUiÇÃO DO PADRÃO DE 40 PPB DE AOH. 93

FigURA 19 - CROMATOGRAMA E ESPECTRO DE AMOSTRA COM DON .......................................95

FIGURA B1 - CURVA ANALÍTICA PARA A QUANTIFICAÇÃO DE DON. ...................................... 129

FigURA B2 - CURVA ANALÍTICA PARA A QUANTIFICAÇÃO DE ZEA. ....................................... 129

Figura B3 - CuRVA ANALÍTICA PARA A QUANTIFICAÇÃO DE AOH. ....................................... 130 


\section{LISTA DE TABELAS}

TABEla 1 - CARACTERÍstiCAS MORFOLÓGICAS DE CONÍDIOS DAS ESPÉCIES ISOLADAS PERTENCENTES AO COMPLEXO FUSARIUM GRAMINEARUM …............................... 32

TABELA 2 - LEVANTAMENTO SOBRE ALGUMAS OCORRÊNCIAS DE DON, ZEA E AOH EM TRIGO E DERIVADOS REALIZADO EM VÁRIOS PAÍSES. 16

TABELA 3 - LIMITES MÁXIMOS DE DON E ZEA EM TRIGO E DERIVADOS NO BRASIL.. 54

TABELA 4 - ÍONS PRECURSORES, ÍONS PRODUTOS E PARÂMETROS FONTE-DEPENDENTES E COMPOSTO-DEPENDENTES OTIMIZADOS. 66

TABELA 5 - PARÂMETROS DA ELUIÇÃO POR GRADIENTE. 67

TABELA 6 - NíveIS DE FORTIFICAÇÃO UTILIZADOS NO TESTE DE RECUPERAÇÃO PARA CADA TOXINA.

TABELA 7 - FREQUÊNCIA MÉdiA DE ISOLAMENTO DE FUNGOS, EM GRÃOS DE TRIGO DOS MUNICÍPIOS DE CAPÃO BONITO E AVARÉ, NAS 7 COLETAS. .74

TABela 8 - Dados de Temperatura MÉdia $\left({ }^{\circ} \mathrm{C}\right)$ E ÍNDiCe PluViométrico MÉdio (MM) REFERENTES AOS MESES DE AGOSTO (2011) A MARÇO (2011), REGISTRADOS DAS REGiões de CAPÃo Bonito e Avaré, SÃo PaUlo. 89

TABELA 9 - VALORES ObTidos PARA O ENSAiO DE RECUPERAÇÃo (\%) E DPR (\%)..... 94

TABELA 10 - VALORES OBTIDOS PARA OS LIMITES DE DETECÇÃO E QUANTIFICAÇÃO EM PPB.... 95

TABELA 11 - DeOXINIVALENOL EM GRÃOS DE TRIGO RECÉM-COLHIDOS E ARMAZENADOS NA REGIÃO DE CAPÃO BONITO. 96

TABELA A1 - FREQUÊNCIA DE ISOLAMENTO DE FUNGOS, EM GRÃOS DE TRIGO RECÉM-COLHIDOS NOS MUNICÍPIOS DE CAPÃo BONITO E AVARÉ. 122

TABELA A2 - FREQUÊNCIA DE ISOLAMENTO DE FUNGOS, EM GRÃOS DE TRIGO DOS MUNICÍPIOS DE CAPÃo Bonito E AVARÉ, APÓs 1 MÊS DE ARMAZENAMENTO.

TABELA A3 - FREQUÊNCIA DE ISOLAMENTO DE FUnGOS, EM GRÃOS DE TRIGO DOS MUNiCíPIOS DE CAPÃo Bonito E AVARÉ, APÓS 2 MESES DE ARMAZENAMENTO. 124

TABEla A4 - FREQUÊNCIA DE ISOLAMENTO DE FUnGOS, EM GRÃOS DE TRIGO DOS MUNICÍPIOS DE CAPÃo Bonito E AVARÉ, APÓS 3 MESES DE ARMAZENAMENTO. 125

TABEla A5 - FREQUÊNCIA DE ISOlamento DE FUnGOS, EM GRÃOS DE TRIGO DOS MUNiĆ́PIOS DE CAPÃo Bonito E Avaré, APÓS 4 MESES DE ARMAZENAMENTO.

TABEla A6 - FrequênCIA DE ISOlAMENTO DE FUnGOS, EM GRÃOS DE TRIGO DOS MUNicíPIOS DE CAPÃo Bonito E AVARÉ, APÓS 5 MESES DE ARMAZENAMENTO. 127 
TABELA A7 - FReQuÊnCIA DE ISOLAMENTO DE FUnGOS, EM GRÃOS DE TRIGO DOS MUNICÍPIOS DE CAPÃo BonITO E AVARÉ, APÓS 6 MESES DE ARMAZENAMENTO. 128

TABEla C1 - ESTATístiCAS DESCRITIVAS PARA A VARIÁVEL CRESCIMENTO DE FUSARIUM SPP. NO TRIGO EM PORCENTAGEM DOS GRÃOS CONTAMINADOS (33 GRÃOS ANALISADOS POR AMOSTRA) 131

TABELA C2 - EstATÍSTICAS DESCRITIVAS PARA A VARIÁVEL CRESCIMENTO DE ALTERNARIA SPP. NO TRIGO EM PORCENTAGEM DOS GRÃOS CONTAMINAdOS (33 GRÃOS ANALISADOS POR AMOSTRA) 132

TABela C3 - Estatísticas descritivas PaRa A VARiável PRODUÇÃo DE DON EM CAPÃO BONITO EM $\mu \mathrm{G} / \mathrm{KG}$. 133

TABEla C4 - EstatístiCAS DESCRITIVAS PARA A VARIÁVEL ATIVIDADE DE ÁGUA NO TRIGO.133 TABELA C5 - VAlORES MÉDiOS DAS VARIÁVEIS ClimATOLÓGICAS NOS 30 DIAS ANTERIORES A CADA COLETA. 134

TABela C6 - Estimativas E VAlORES-P DO AJUSTE DO MODElo DE REGRESSÃO BinOMIAL PARA A VARIÁVEL CRESCIMENTO DE FUSARIUM SPP. 134

TABElA C7 - VALORES-P DAS VARIÁVEIS NÃO INCLUÍDAS NO MODELO DE REGRESSÃO BINOMIAL PARA A VARIÁVEL CRESCIMENTO DE FUSARIUM SPP.. 135

TABEla C8 - VAlORES-P DAS COMPARAÇÕES MÚltiplas NO MODElO DE REGRESSÃo BINOMIAL PARA A VARIÁVEL CRESCIMENTO DE FUSARIUM SPP. 135

TABela C9 - Estimativas E VAlORES-P DO AJUSTE DO MODElO DE REGRESSÃO BINOMIAL PARA A VARIÁVEL CRESCIMENTO DE ALTERNARIA SPP. 136

TABEla C10 - VAlORES-P DAS VARIÁVEIS NÃO INCLUÍdAS NO MODELO DE REGRESSÃO BINOMIAL PARA A VARIÁVEL CRESCIMENTO DE ALTERNARIA SPP. 136

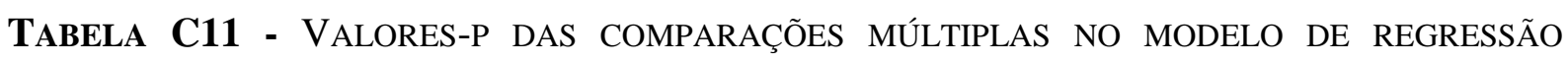
BINOMIAL PARA A VARIÁVEL CRESCIMENTO DE ALTERNARIA SPP.

TABELA C12 - ESTIMATIVAS E VALORES-P DO AJUSTE DO MODELO DE REGRESSÃO GAMA PARA A VARIÁVEL PRODUÇão DE DON. 138

TABEla C13 - VALORES-P DAS VARIÁVEIS NÃO INCLUÍDAS NO MODELO DE REGRESSÃO GAMA PARA A VARIÁVEL PRODUÇÃO DE DON. 138

TABEla C14 - VALORES-P DAS COMPARAÇÕES MÚlTIPLAS NO MODELO DE REGRESSÃO GAMA PARA A VARIÁVEL PRODUÇÃO DE DON. 138 


\section{LISTA DE ABREVIATURAS E SIGLAS}

A. - Alternaria

Aa - Atividade de água

Alt a 1 -

ALT - Altenueno

AME - Alternariol monometil éter

ANOVA - Análise Normal de Variância

AOAC - Association of Oficial Agricultural Chemists

$\mathrm{AOH}$ - Alternariol

${ }^{\circ} \mathrm{C}$ - Graus Celsius

CAD - CAD Gás

CCD - Cromatografia em camada delgada

$\mathrm{CG}$ - Cromatografia gasosa

CLAE - Cromatografia líquida de alta eficiência

CUR - Curtain gas

CXP - Collision Cell Exit Potential

DAD - Detecção por arranjo de diodo

DNA - Ácido desoxirribonucleico

dNTP - Desoxiribonucleotídeo trifosfato

DO - Densidade óptica

DON - Deoxinivalenol

DP - Declustering Potential

DPR-Desvio padrão relativo

EMBRAPA - Empresa Brasileira de Pesquisa Agropecuária

EP - Entrance Potential

ESI - Ionização por electrospray

F. - Fusarium

FAO - Food and Agriculture Organization

FDA - Food and Drug Administration

FHB - Fusarium head blight

FIA - Flow Injection Analysis

FLD - Detecção por fluorescência

GNC - Grãos não contaminados

GS1 - Gás 1

GS2 - Gas 2

IAC - Instituto Agronômico de Campinas

IS - Ionspray voltage

$\mathrm{kV}$ - Kilovolt

LAMIC - Laboratório de Análises Micotoxicológicas

LC-MS/MS - Cromatografia Líquida de Alta Eficiência Acoplada a Espectrometria de

Massas Sequencial

LMT - Limite máximo tolerável

LODi - Limite de detecção do instrumento

LOQi - Limite de quantificação do instrumento

LODm - Limite de detecção do método

LOQm - Limite de quantificação do método

mg - Miligrama

min. - Minutos

$\mathrm{ml}$ - Mililitro 


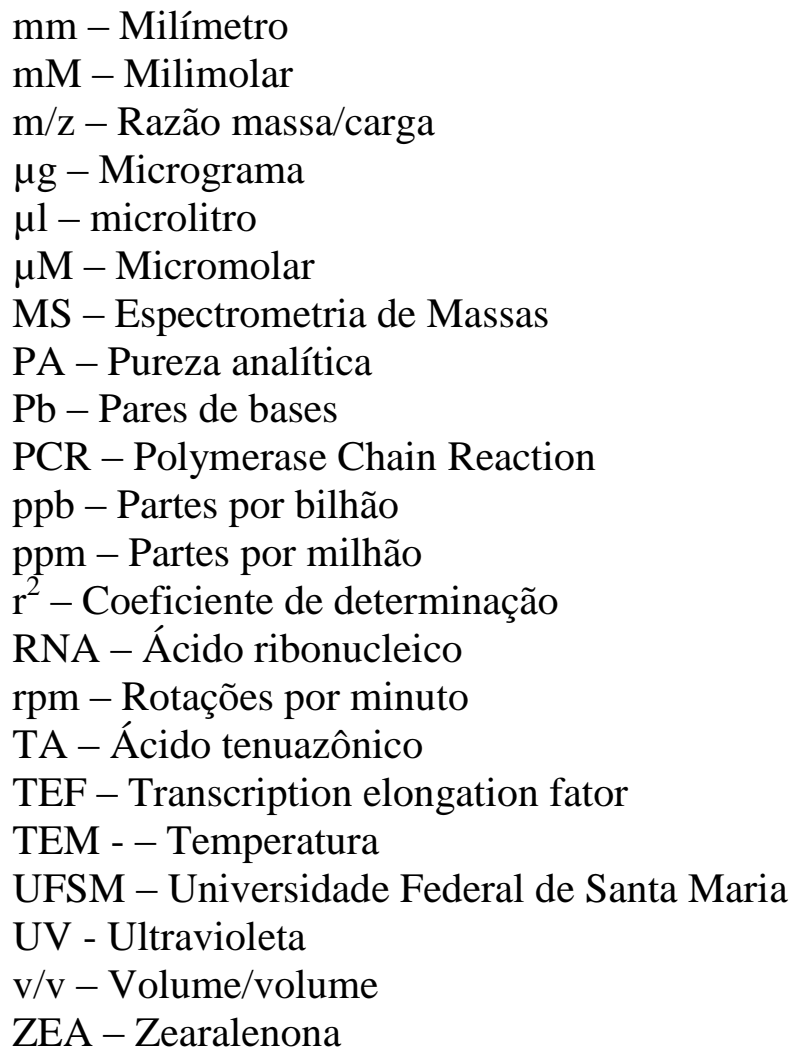




\section{SUMÁRIO}

1 INTRODUÇÃ

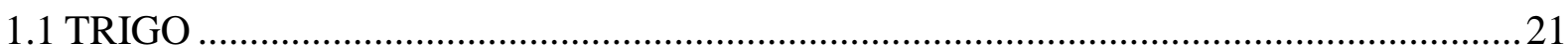

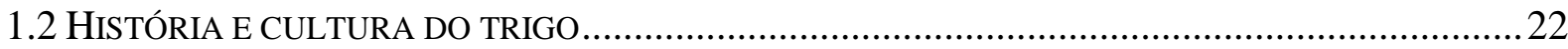

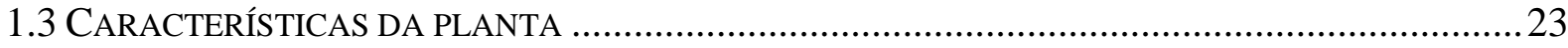

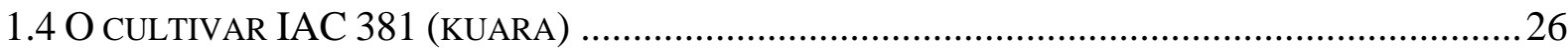

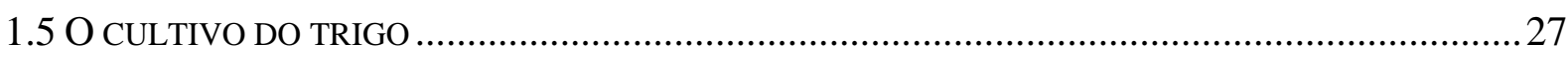

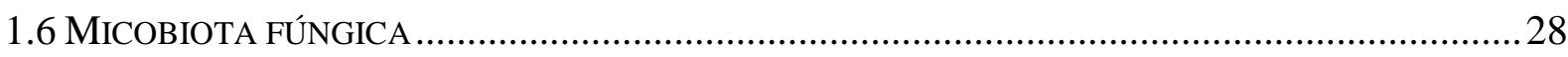

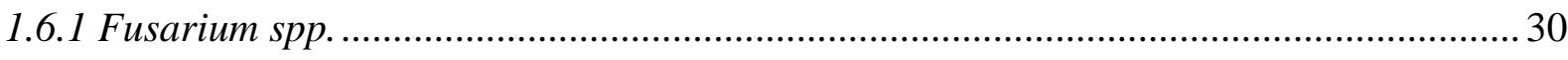

1.6.2 Fusarium graminearum....................................................................................... 31

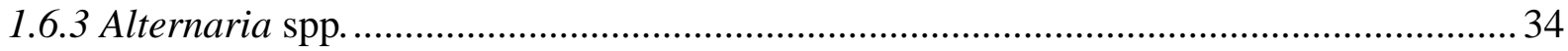

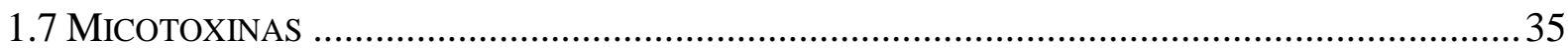

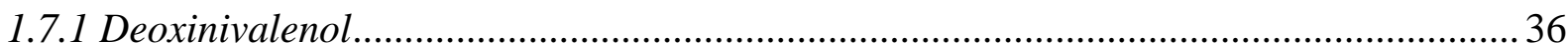

1.7.2 Zearalenona

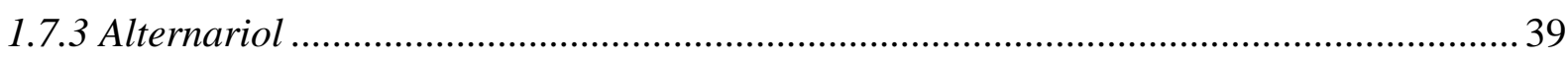

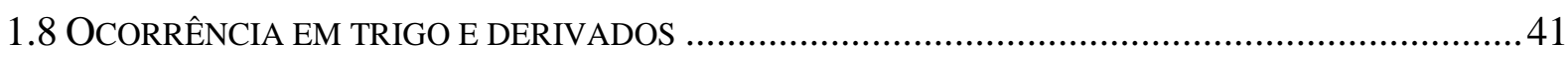

1.9 CROMATOGRAFIA LíQuida DE ALTA EFICIÊNCIA ACOPLADA À ESPECTROMETRIA DE

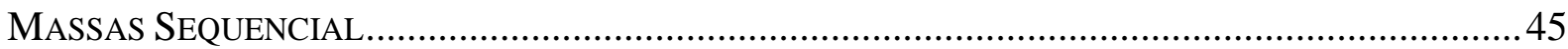

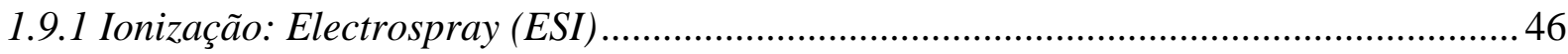

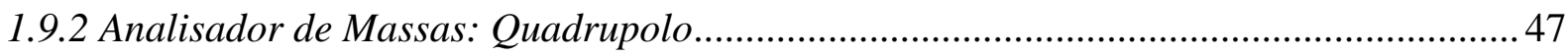

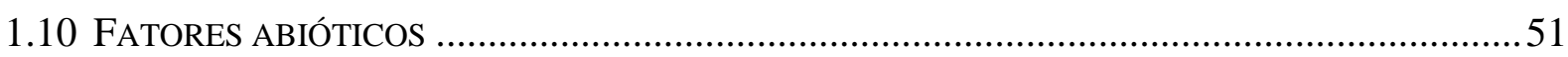

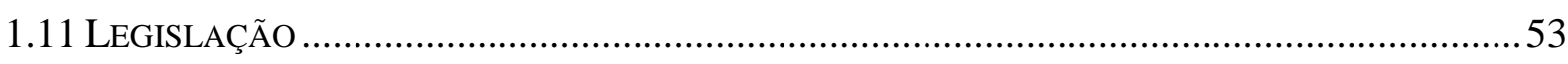

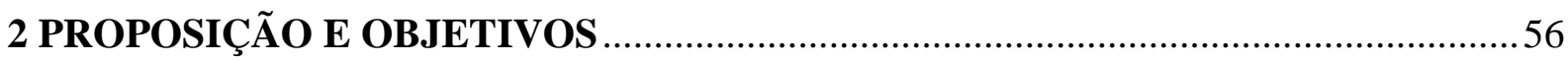

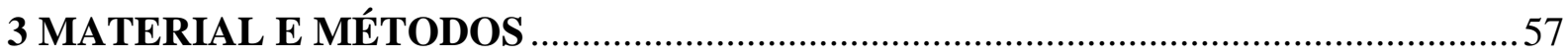

3.1 CARACTERIZAÇÃO DAS UNIDADES EXPERIMENTAIS ..........................................................57

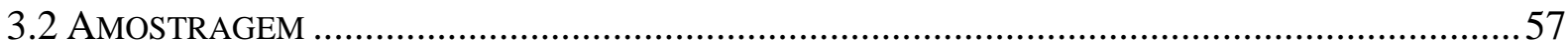

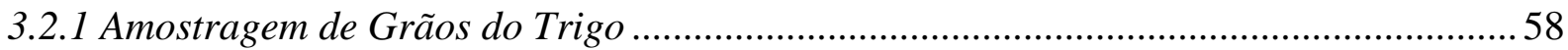

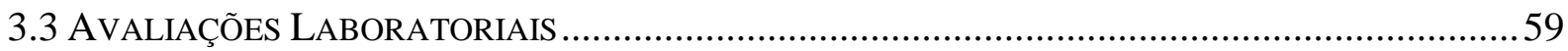

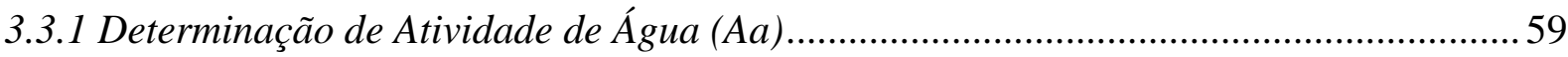

3.3.2 Técnica da Semeadura Direta para o Isolamento da Micobiota Fúngica dos Grãos de

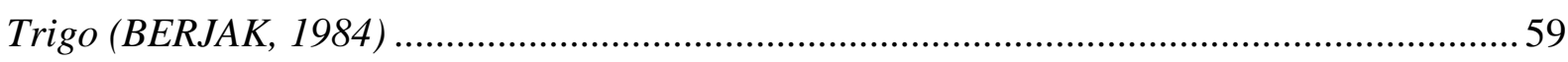


3.3.3 Identificação dos Isolados de Fusarium spp. e Alternaria spp ....................................... 60

3.3.3.1 Obtenção de Massa Fúngica e Extração de DNA ….....................................................60

3.3.3.2 Quantificação do DNA de Fusarium spp. e Alternaria spp. ...................................... 61

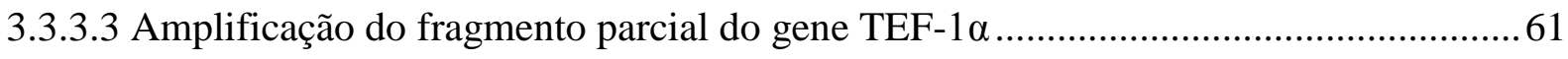

3.3.3.4 Amplificação do fragmento parcial do gene Alt a 1 ..................................................62

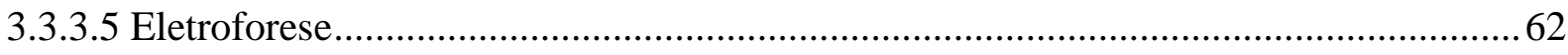

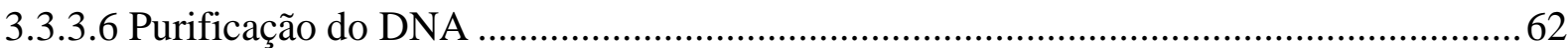

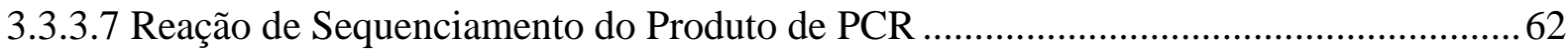

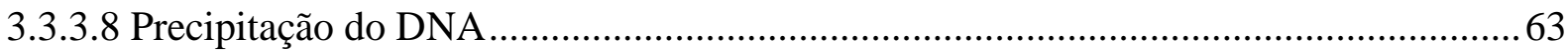

3.3.3.9 Análise das Sequências do Gene TEF-1 $\alpha$ das Amostras de Fusarium spp. e do gene

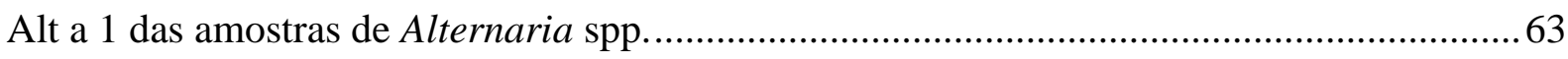

3.3.4 Determinação de Micotoxinas nas Amostras de Trigo .................................................. 63

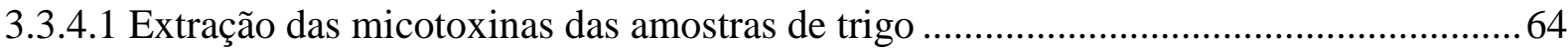

3.3.4.2 Cromatografia Líquida de Alta Eficiência acoplada à Espectrometria de Massas

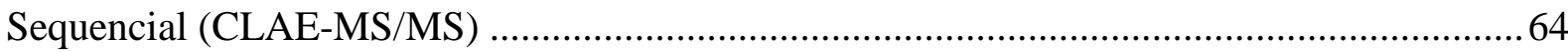

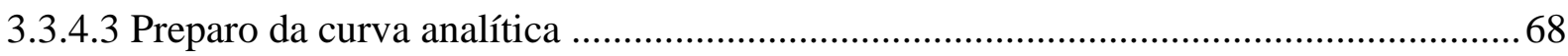

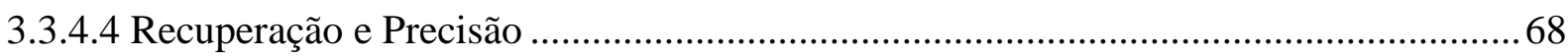

3.3.4.5 Limite de detecção e limite de quantificação ............................................................. 70

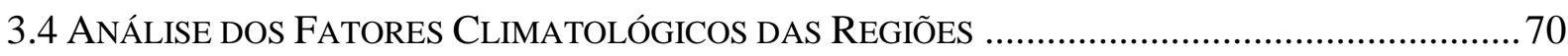

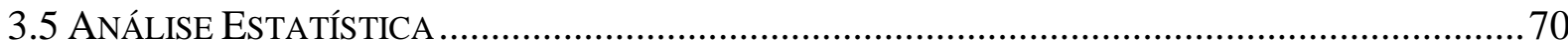

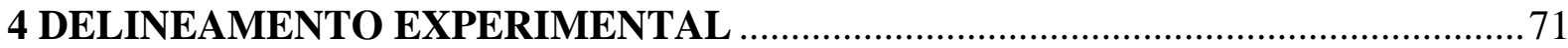

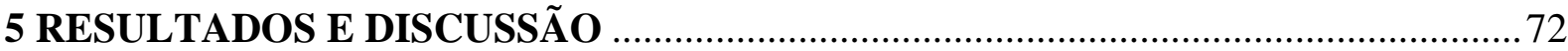

5.1 МісовІотА

5.1.1 Identificação dos isolados dos gêneros Fusarium e Alternaria no trigo recém-colhido e

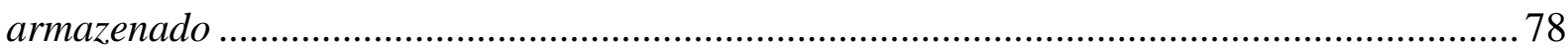

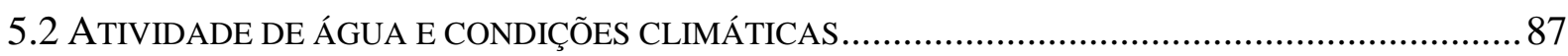

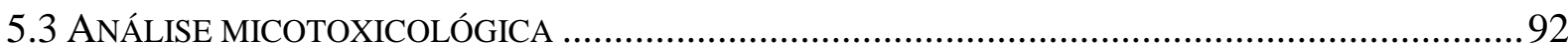

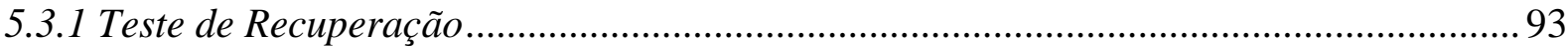

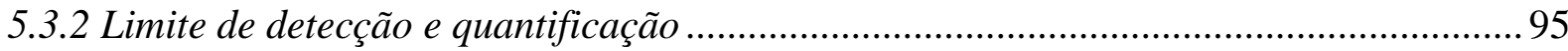

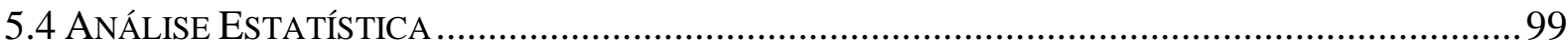

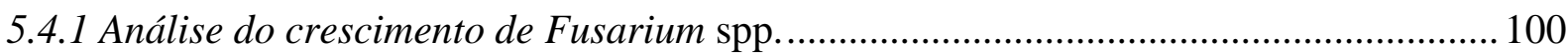

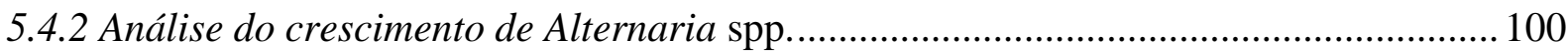

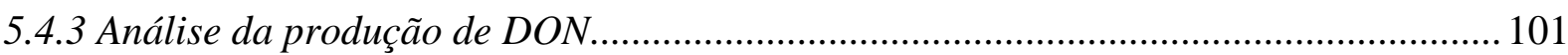


6 CONCLUSÕES

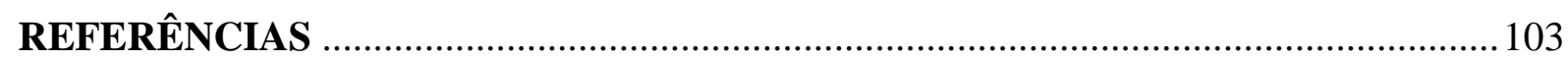

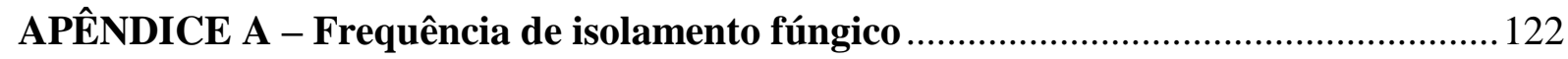

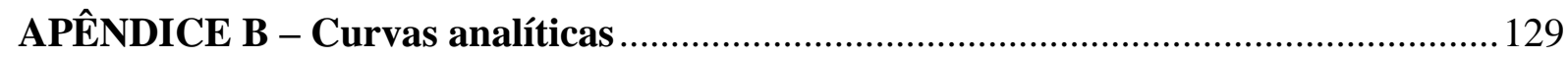

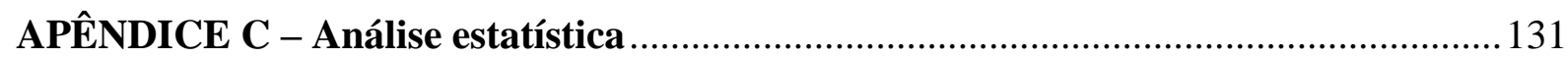




\section{INTRODUÇÃO}

\subsection{TRIGO}

O trigo é o segundo cereal mais produzido no mundo, com significativo peso na economia agrícola global e na alimentação humana, pela qualidade nutritiva e versatilidade no uso (EMPRESA BRASILEIRA DE PESQUISA AGROPECUÁRIA, 2011b). O grão é consumido na forma de pão, massa alimentícia, bolo e biscoitos, farinha, entre outros. Também pode ser usado como ração animal, quando não atinge a qualidade exigida para consumo humano (BRASIL, 2011a).

O trigo fornece cerca de $20 \%$ das calorias provenientes de alimentos consumidos pelo homem. Possui o glúten, uma proteína não encontrada em outros grãos, o que faz do trigo componente indispensável para muitos alimentos. O trigo é útil ao homem através de seus derivados imediatos, farinhas (branca e integral) e triguilho. Farelo de trigo (subproduto da obtenção da farinha branca) ou trigo integral adicionado diariamente a mingaus, sopas e outros alimentos proporcionam bom funcionamento do aparelho digestivo do homem prevenindo doenças do cólon e reto, apendicites, problemas cardíacos, entre outros. O farelo de trigo é usado em arraçoamento de bovinos, suínos e aves (SECRETARIA DE AGRICULTURA, PECUÁRIA, IRRIGAÇÃO, REFORMA AGRÁRIA, PESCA E AQUICULTURA, 2012).

É o produto de origem vegetal de maior diversidade industrial para o consumo humano e uma das culturas mais produtivas do mundo (AGRONET, 2013). A produção de trigo representa cerca de $30 \%$ da produção mundial de cereais e ocupa $20 \%$ da área cultivada no mundo (SEAGRI, 2012). O cultivo do trigo é tão disseminado pelo mundo inteiro que em qualquer mês do ano ele é colhido em alguma parte de nosso planeta (BRASIL, 2013b).

Sua produção está em torno de 500 milhões de toneladas/ano tendo como principais produtores mundiais a Rússia, Estados Unidos da América, China, Índia e França (SEAGRI, 2012).

Em 2010, a produção mundial chegou a 684 milhões de toneladas (UNITED STATES DEPARTMENT OF AGRICULTURE, 2011). De acordo com o Conselho Internacional de Grãos (IGC, 2013), a produção mundial de trigo 2013/2014, chegará a 690 milhões de toneladas e em 4 anos, 2017/2018 alcançará produção de 731 milhões de toneladas, mesmo valor previsto para consumo. 
No Brasil, o trigo é uma cultura de grande importância sócio-econômica, destacandose o fato de que o consumo brasileiro do produto, nos últimos 3 anos, foi em torno de 10 milhões de toneladas, sendo 5-6 milhões de produção nacional (BRASIL, 2011a). Países como Argentina, Paraguai, Ururguai, Estados Unidos e Canadá figuram na lista dos principais exportadores de trigo para o Brasil (COMPANHIA NACIONAL DE ABASTECIMENTO, 2013b).

As regiões Sul, Centro-Oeste e Sudeste são as principais regiões produtoras no país, sendo que Paraná e Rio Grande do Sul totalizam mais de $90 \%$ da produção. Contudo, os estados de Goiás, Minas Gerais, São Paulo e Santa Catarina também são responsáveis pelo fornecimento de trigo (BRASIL, 2013c).

A produção nacional de trigo para o exercício 2013/14 deverá atingir 5.609,8 mil toneladas, representando um incremento de $28,1 \%$ em relação à safra passada. A área plantada de trigo na safra 2013/14 deverá apresentar um incremento de 10,3\% em relação à safra anterior, atingindo 2.089,7 mil hectares, contra 1.895,4 na safra 2012/13 (CONAB, 2013a). Estimativas do ministério preveem uma taxa de aumento de consumo do trigo de $1,31 \%$ ao ano (BRASIL, 2011b).

No entanto, graças ao trabalho das instituições de pesquisa brasileiras, em especial da Embrapa, há uma expectativa de que o Brasil, por apresentar área e condições suficientes, possa se tornar auto-suficiente na produção de trigo nos próximos dez anos, tanto pelo aumento da produção nas regiões tradicionais, quanto pela incorporação de novas áreas, como os cerrados (AGRONET, 2013).

Devido à importância do trigo e seus derivados na alimentação do homem, visando amenizar a deficiência de vitaminas e minerais nos alimentos consumidos pela população, o Governo Federal determinou, em 2002, a obrigatoriedade da adição de ferro e ácido fólico na farinha de trigo, processo conhecido como biofortificação (AGÊNCIA NACIONAL DE VIGILÂNCIA SANITÁRIA, 2002). As farinhas de trigo, pelo seu largo consumo, foram identificadas como veículos adequados para a estratégia de fortificação alimentar o que, mais uma vez, evidencia os benefícios deste alimento à população.

\subsection{HISTÓRIA E CULTURA DO TRIGO}

O trigo, pertencente à família das gramíneas e ao gênero Triticum é, desde a préhistória, o mais importante dos cereais, sendo provavelmente, a mais antiga planta cultivada. Serviu de sustento às civilizações da Mesopotâmia e do Nilo, e conquistou a Europa 
(CARVALHO; NAKAGAWA, 1988). Devido a sua adaptação a muitos tipos de solo e climas, sua faixa de cultivo estende-se entre 30 a $60^{\circ}$ da latitude Norte e 20 a $40^{\circ}$ da latitude Sul. Em condições particulares encontra-se também no equador e no círculo polar (QUAGLIA, 1991).

A origem do trigo é bastante remota. O homem cultiva o Triticum vulgare, pelo menos, há seis mil anos, no início, triturando-o entre pedras rústicas para aproveitar a farinha. Foram encontrados grãos de trigo nos jazigos de múmias do Egito, nas ruínas das habitações lacustres da Suíça e nos tijolos da pirâmide de Dashur, cuja construção data de mais de três mil anos a.C. (BRASIL, 2011d).

No Brasil, há relatos que o cultivo do trigo tenha se iniciado em 1534, na antiga Capitania de São Vicente. A partir de 1940, a cultura começa a se expandir comercialmente no Rio Grande do Sul. Nessa época, colonos do Sul do Paraná plantavam sementes de trigo trazidas da Europa em solos relativamente pobres, onde as cultivares de porte alto apresentavam melhor adaptação. A partir de 1969/70, o trigo expandiu- se para as áreas de solos mais férteis do norte/oeste do Paraná e, em 1979, o Estado assumiu a liderança na produção de trigo no Brasil (BRASIL, 2011e).

\subsection{CARACTERÍSTICAS DA PLANTA}

Embora o trigo represente uma fonte de alimento completa em termos nutricionais, a proporção das várias substâncias que compõem o grão (amido, minerais, vitaminas e proteínas) oscila conforme a variedade. (ASSOCIAÇÃO BRASILEIRA DA INDÚSTRIA DO TRIGO, 2011).

Os cereais assim como os demais membros da família Apoaceae (antiga nomenclatura Gramineae), chamados cariopses ou grãos, produzem frutos secos. No grão, identificam-se duas partes distintas: o pericarpo e a semente. A parte mais externa é o pericarpo, que recobre toda a semente e é composto por 6 camadas (epiderme, hipoderme, remanescentes da parede celular ou células finas, células intermediárias, células cruzadas e células tubulares). A semente é formada pelo endoesperma e o germe, que são recobertos por 3 camadas: testa (onde estão os pigmentos que dão cor ao grão), camada hialina e aleurona (HOSENEY, 1986).

Do ponto de vista tecnológico, o grão de trigo pode ser dividido em três partes distintas: endosperma (83\%), farelo (14\%) e germe (3\%). Cada parte compreende dois ou mais tecidos anatomicamente diferentes (BUSHUK, 1986). 
Figura 1 - Seções Longitudinal e Transversal de um Grão de Trigo.
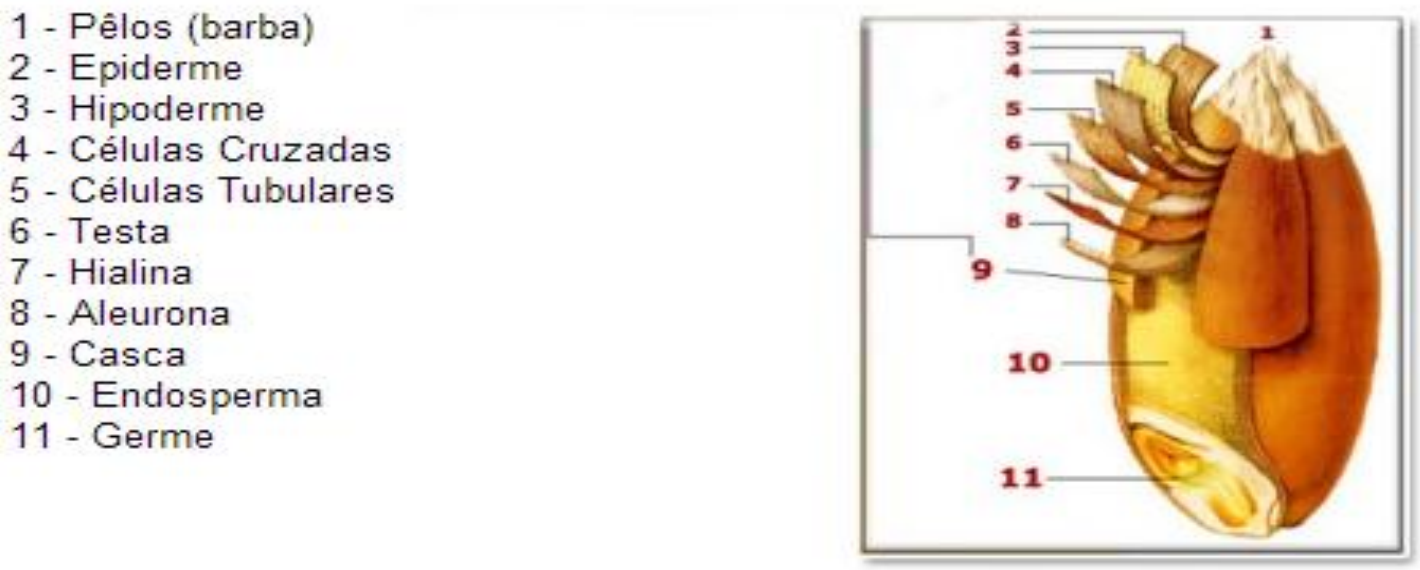

Fonte: SM ALIMENTOS, 2013

Os constituintes químicos não se distribuem uniformemente pelo grão. O pericarpo (cerca de 5\% do peso do grão) é rico em pentosanas, celulose, cinzas e proteína. A aleurona (7\%) é uma camada rica em cinza (fósforo, fitato), proteína, lipídios, vitaminas (niacina, tiamina, riboflavina) e enzimas. O endosperma (82\%) é composto basicamente de amido, mas sua parte mais externa (subaleurona) contém mais proteína que a porção interna. O germe (3\%) tem alto conteúdo de proteína, lipídios, açúcares redutores e cinzas. (SM ALIMENTOS, 2013).

A planta pode atingir de 0,5 a 1,5 $\mathrm{m}$ de altura, tem raízes em forma de cabeleira, caule oco e reto (colmo), 6 a 9 folhas estreitas e compridas, flores em grupo de 3 a 5 formam espiguetas que se agrupam em número de 15 a 20, formando espigas. O fruto, uma cariopse (ou grão), é seco, pequeno e conclui desenvolvimento 30 dias após fecundação da flor (SEAGRI, 2012).

O trigo está entre as plantas mais cultivadas no mundo. Existem cerca de 30 tipos de trigo, geneticamente diferenciados, dos quais metade é cultivada; o restante cresce de forma silvestre. Em sua maioria, classifica-se em 3 espécies: a Triticum aestivum L., predominante na produção mundial; a Triticum compactum Host. e a Triticum durum Dest, os quais representam mais de $90 \%$ do trigo cultivado no mundo. Cada uma delas é mais adequada a um tipo de alimento: 
Triticum aestivum - Chamado de trigo comum, é o mais cultivado, respondendo por mais de 4/5 da produção mundial e o mais utilizado na fabricação do pão. A variedade mais consumida no Brasil, Triticum aestivum L., tem um teor de proteína em torno de $15 \%$.

Triticum compactum - Conhecido também como tipo clube, tem um teor de proteínas da ordem de $8 \%$, produzindo menor teor de glúten, substância que está por trás do crescimento e da textura dos produtos feitos com farinha. É utilizado para a fabricação de biscoitos e bolos mais macios e menos crocantes.

Triticum durum - Indicado para massas (macarrão), essa espécie forma um glúten mais resistente, permitindo uma textura firme após o cozimento. O grão duro não é cultivado no Brasil (ABITRIGO, 2011).

Figura 2 - Imagens das três principais espécies de trigo.
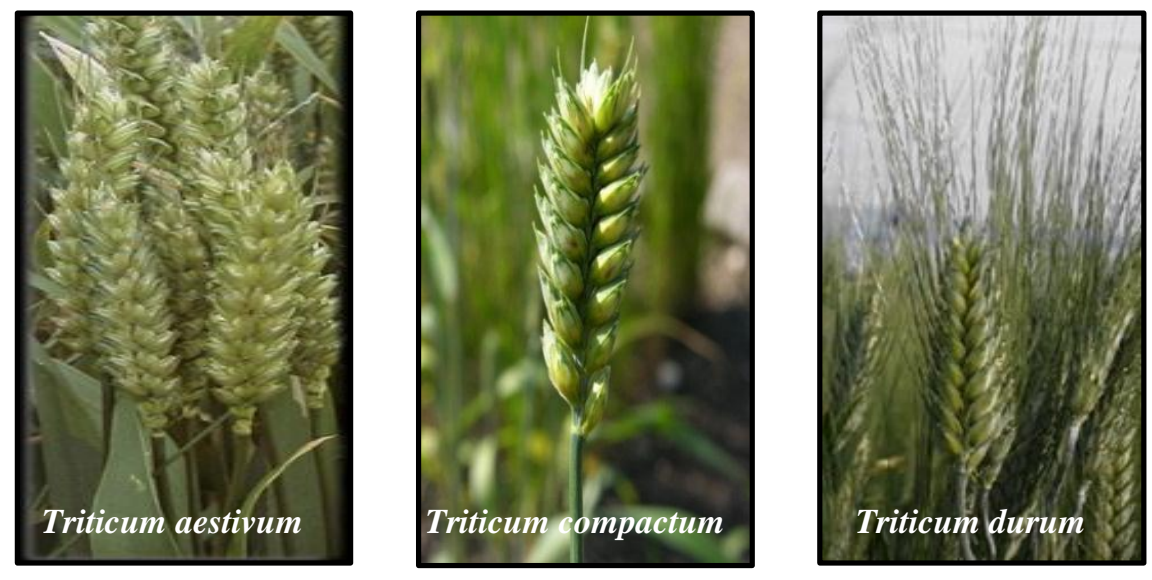

Fonte: ABITRIGO, 2011

A semente do trigo é o principal e mais eficiente veículo de transmissão e disseminação de patógenos o que implica tanto na introdução de patógenos em áreas ainda livres ou de raças mais virulentas, ainda não existentes, quanto na ocorrência de infecção, nos estádios iniciais de desenvolvimento da planta, com aumento da incidência de doenças já existentes (MACHADO, 1982; TANAKA; MACHADO, 1985). Muitas doenças que ocorrem no Brasil foram introduzidas por meio de sementes que carregavam, interna ou externamente, organismos patogênicos (TANAKA, 1982).

As patogenicidades associadas a sementes incluem podridão radicular, tombamento de mudas, manchas necróticas em folhas e caules, deformações como subdesenvolvimento, descoloração de tecidos e infecções latentes e morte (NEERGAARD, 1979). 
1.4 O CULTIVAR IAC 381 (KUARA)

Pertence à espécie Triticum aestivum L.

Figura 3 - Dados informativos do cultivar IAC 381.

\begin{tabular}{|c|c|}
\hline Ano de lançamento & 2009 (N. relerência RNC 23300 ) \\
\hline Procedẻncia & Instituto Agronómico de Campinas \\
\hline Origem & Cruzamentox CMH.75"66/SERI/3/BH1146/AA"S"MINS" \\
\hline Tipo de cultura & Sequeiro e irnigado \\
\hline Ciclo & 130 a 1356ias (ntemediasionarcio) \\
\hline Espigamento & 60 a 70 dias após a emergéncia \\
\hline Época de plantio & 1 de abri a 31 de maio (de acordo com a regisao e a infigaçăo) \\
\hline Espaçamento entrelinhas & 0,17 a $0,20 \mathrm{~m}$ \\
\hline Gasto de sementes & 140 a $150 \mathrm{~kg} / \mathrm{ha}$ \\
\hline Estande & 300 a 350 plantas/m ${ }^{2}$ \\
\hline Caracteristicas da planta & $\begin{array}{l}\text { Porte: intermediário } \\
\text { Altura da plantac } 0,85 \text { a } 0,90 \mathrm{~m} \\
\text { Cor da auricula: ausencia de antocianina }\end{array}$ \\
\hline Caracteristicas da espiga & $\begin{array}{l}\text { Forma: oblonga } \\
\text { Cor na maturaçăo: clara } \\
\text { Avista: normal }\end{array}$ \\
\hline Tipo de grảo & Duro (pâo) \\
\hline Produtividade média & 3.000 a $5.000 \mathrm{kgha}$ \\
\hline & $\begin{array}{l}\text { Resistente: ferngem-da-folha, oidio. } \\
\text { Moderadamente resistente: brusone. Espigas com moderada } \\
\text { resistencia a Giberella e mancha-da-gluma. }\end{array}$ \\
\hline |Kesistencia a doenças & $\begin{array}{l}\text { Moderadamente suscetivel: manchas foliares causadas por } \\
\text { Bipolaris sorokiniana e Drechslera tritici-repentis. } \\
\text { Suscetivel: Giberella. }\end{array}$ \\
\hline Regióes indicadas para plantio & $\begin{array}{l}\text { Regióes triticolas do Estado de Săo Paub: Zonas A, A1, B e } \\
\text { C, sequeiro e irrigado. Nas dema's Zonas Triticolas (Zonas D, } \\
\text { E, F, G e H) cultivar somente com irnigaçšo por aspersăo. }\end{array}$ \\
\hline Observaçōes & $\begin{array}{l}\text { - Destaca-se pela rusticidade. } \\
\text { - Resistencia ao acamamento bos. } \\
\text { - Resistente a debulha natural e à germinação na } \\
\text { espiga } \\
\text { - Toleráncia média ao aluminio toxico no solo. } \\
\text { - Exigència media em fertlidade do solo. } \\
\text { - Qualidade industrial: trigo pão. }\end{array}$ \\
\hline
\end{tabular}

Fonte: Instituto Agronômico de Campinas (IAC), 2012. 
Figura 4 - Estádios fenológicos do trigo.

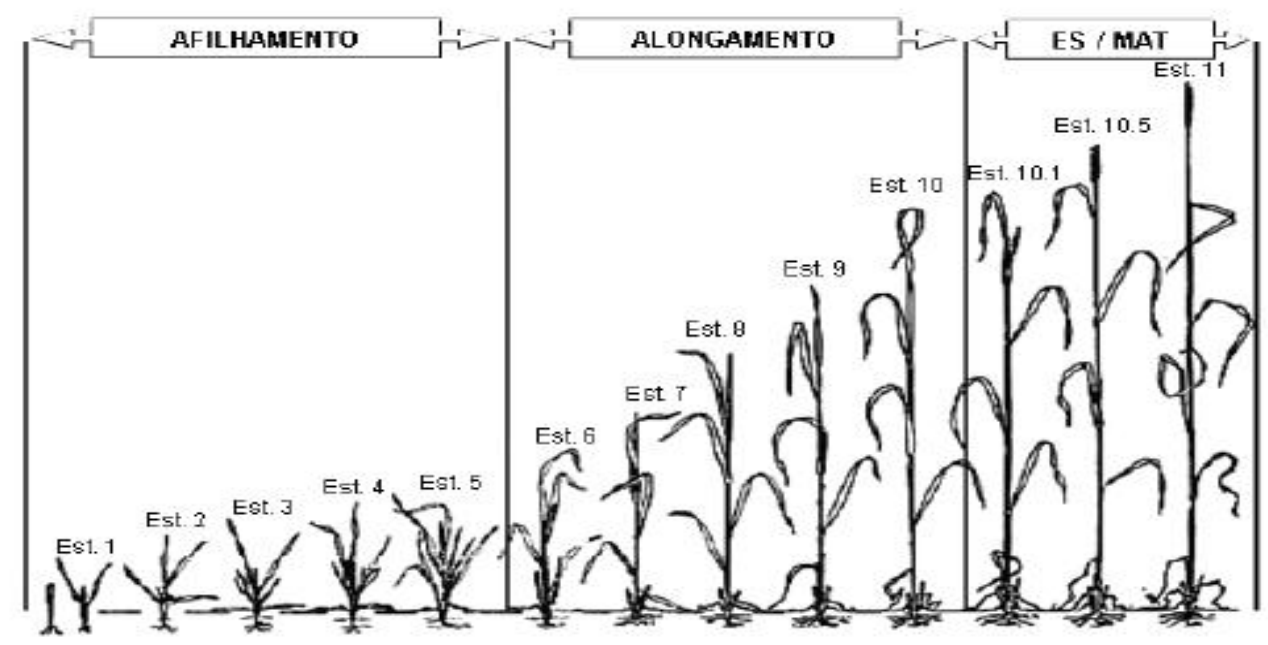

\begin{tabular}{cl}
\hline Estádio & Afilhamento \\
\hline 1 & Plantas recém-emergidas, com uma ou mais folhas. \\
3 & $\begin{array}{l}\text { Início do afilhamento. } \\
\text { Afilhos formados. Folhas enroladas em espiral. Algumas cultivares } \\
\text { pode apresentar hábito prostrado. }\end{array}$ \\
4 & $\begin{array}{l}\text { Inicio do aparecimento do pseudocaule. Bainhas foliares começam a } \\
\text { alongar-se. }\end{array}$ \\
\hline Estádio & Pseudocaule (formado por bainhas foliares) fortemente desenvolvido. \\
\hline 6 & Primeiro nó do calmo visível. \\
7 & Segundo nó do colmo já formado. \\
& Folha bandeira visível, mas ainda enrolada. Início do período de \\
9 & emborrachamento. \\
10 & Lígula da folha bandeira já visível. \\
& Bainha da folha bandeira completamente desenvolvida, mas as \\
\hline Estádio & Espigamento nainda são visíveis. \\
\hline 10.1 & Primeiras espigas recém-visiveis. \\
10.2 & Um quarto do processo de espigamento completo. \\
10.3 & Metade do processo de espigamento completo. \\
10.4 & Três quartos do processo de espigamento completo. \\
10.5 & Todas as espigas fora das bainhas. \\
\hline Estádio & Florescimento \\
\hline 10.5 .1 & Início do florescimento. \\
10.5 .2 & Florescimento completo na parte apical da espiga. \\
10.5 .3 & Florescimento completo na parte basal da espiga. \\
10.5 .4 & Final do florescimento, grãos no estágio aquoso. \\
\hline Estádio & Maturação \\
\hline 11 & Grãos no estádio leitoso a maturação. \\
11.1 & Grãos no estádio leitoso. \\
11.2 & Grãos no estádio de massa (conteúdo macio e seco). \\
11.3 & Grãos duros (dificeis de serem rompidos com a unha do polegar). \\
11.4 & Maturação de colheita. Palhas secas. \\
\hline &
\end{tabular}

Fonte: Large; Feeks, 1954. 
O rendimento de grãos e as características de qualidade tecnológica são fortemente influenciados pelas condições climáticas e meteorológicas durante a safra. Excesso de chuva após a maturação fisiológica, período de colheita, geadas e déficit hídrico no florescimento, que comumente ocorrem nas regiões subtropicais; umidade e temperatura do ar elevadas durante o período de florescimento e enchimento de grãos, característicos de regiões tropicais, são as principais causas da perda de rendimento físico e padrão de qualidade tecnológica dos grãos (BRASIL, 2011c).

Na região Sudeste, o Estado de São Paulo, terceiro em produção de trigo no país, possui clima subtropical e os invernos coincidem com a época de floração e formação do grão, justamente quando a semente está mais suscetível à contaminação (FURLONG, 1992). O plantio do cereal aparece como uma boa alternativa para o período de inverno, em função das baixas temperaturas coincidirem com o desenvolvimento vegetativo (CONAB, 2013c).

Quando há infecção precoce (início das fases de florescimento e enchimento de grão), os grãos, se houver, apresentam-se deformados, pequenos e com baixo peso específico, e a maioria é eliminada nos processos de colheita e beneficiamento (BRASIL, 2013a).

O beneficiamento é importante e necessário para se produzir um produto limpo e padronizado, em condições de ser embalado e comercializado. Com o beneficiamento tem-se por objetivo remover não apenas as impurezas como também os grãos que não apresentem as características desejáveis, afim de que o produto adquira as qualidades físicas, fisiológicas e sanitárias de padrões comerciais (BRASIL, 2012b).

\subsection{MICOBIOTA FÚNGICA}

Segundo Machado (1988), dentre os agentes patogênicos, os fungos são os mais ativos, apresentando maior habilidade em penetrar diretamente nos tecidos vegetais e se alojarem mais facilmente. Alguns fungos penetram diretamente no hospedeiro e outros através de aberturas naturais ou ferimentos. Os esporos são propagados pelo ar, água e animais (KOKALIS-BURELLE et al., 1997).

Os alimentos, independentemente de sua origem, apresentam uma micobiota natural extremamente variável, concentrada principalmente na região superficial. Os fungos e as bactérias são os microrganismos de maior destaque, tanto como agentes potenciais de deterioração do produto, ou como eventuais patógenos do homem. Porém, nas diferentes etapas de processamento, os alimentos estão sujeitos à contaminação por diversos outros microrganismos que não fazem parte desta micobiota natural (LEITÃO, 1988). Crescem em 
uma grande variedade de substratos, principalmente nos grãos, prejudicando assim a qualidade do produto (SANTOS et al., 2001).

Assim, os grãos em geral, são constantemente expostos, no campo, a uma ampla variedade de microrganismos, provenientes da poeira, água, plantas doentes, insetos, fertilizantes e material orgânico de animais. Seus esporos ou fragmentos de micélio darão início a contaminação e desenvolvimento do fungo na planta, particularmente em sementes imaturas. A quantidade e os tipos destes microrganismos dependem da resistência dos mesmos, do tipo de solo, da presença de roedores e especialmente de condições climáticas presentes (SILLIKER; ELLIOTT, 1980), além do estágio de desenvolvimento e maturação do grão (LACEY, 1975).

A colonização dos grãos por microorganismos se inicia na emergência da espiga e permanece até o armazenamento. No entanto, a colheita marca uma profunda mudança nos fatores ecológicos afetando o crescimento de microorganismos e resultando em uma mudança marcante na micobiota. A colonização por fungos filamentosos aumenta após a colheita (LACEY; MAGAN, 1991).

O desenvolvimento destes microrganismos não ocorre somente no campo, mas também durante o processo de formação das sementes, na colheita, nas fases de secagem, beneficiamento e armazenamento (ROSSETTO; SILVA; ARAÚJO, 2005); e também no manuseio e transporte até o consumidor (SANTOS et al., 2001).

Em geral, os fungos podem ser divididos em dois grupos, de acordo com o momento da contaminação, e são chamados fungos de campo e fungos de armazenamento. (COUNCIL FOR AGRICULTURAL SCIENCE AND TECHNOLOGY, 2003). Os fungos de campo são aqueles que invadem os tecidos da planta durante o crescimento no campo, necessitando para seu desenvolvimento, uma elevada umidade relativa do ar (cerca de $80 \%$ ) e altos teores de água nos grãos (20 a 21\%). Abaixo de $21 \%$ de umidade, quando nenhuma água livre está disponível no interior dos grãos, os fungos de campo aparentemente morrem e os fungos de armazenamento aparecem, necessitando teores de umidade mais baixos, entre 13 e $18 \%$. No campo, são comuns fungos do gênero Fusarium, Alternaria, Cladosporium e Helminthosporium (CHRISTENSEN; SAUER, 1982).

Segundo Thiel et al. (1991), as regiões tropical e subtropical são as mais favoráveis para a contaminação fúngica. Deste modo, o Brasil apresenta condições ideais para o desenvolvimento destes microrganismos em cereais e grãos.

A disponibilidade de água livre (atividade de água), o $\mathrm{pH}$, a temperatura no processo e na estocagem, a atmosfera de armazenamento, a consistência do alimento, as características 
nutricionais e os efeitos de conservantes são os principais fatores que afetam o crescimento dos fungos em alimentos (PITT; HOCKING, 2009).

Os efeitos da invasão fúngica nos grãos podem levar à diminuição do poder de germinação, crescimento fúngico, descoloração, odor desagradável, perda de matéria seca, aquecimento, cozimento, mudanças químicas e nutricionais como perda de carboidratos, proteínas e vitaminas, e produção de micotoxinas, o que os torna impróprios para consumo, resultando em significativa perda da qualidade do produto e grandes perdas econômicas (POMERANZ, 1982).

A biodegradação de matérias-primas e de alimentos é um dos principais efeitos deletérios associados à contaminação fúngica, e o conhecimento das características morfológicas e fisiológicas de certas espécies fúngicas, permite o desenvolvimento de medidas preventivas contra o seu desenvolvimento em diferentes substratos (SANTOS, 2011).

\subsubsection{Fusarium spp.}

A característica que define o gênero Fusarium é a produção de conídios septados, de forma fusiforme, denominados macroconídios, que podem ser produzidos em pústulas, chamados esporodóquios, ou em massas viscosas, conhecidas como fiálides. Muitas espécies de Fusarium também produzem conídios menores, microconídios, de várias formas. Clamidoconídios, terminais ou intercalantes, são característicos de algumas espécies também. Colônias de Fusarium spp. são geralmente de crescimento rápido e consistem de micélio claro ou brilhantemente colorido em tons de rosa, vermelho, violeta ou marrom. Alguma espécies têm teleomorfos, não produzidos em cultura (PITT; HOCKING, 2009).

É uma das principais causas de apodrecimento de frutas e vegetais armazenados e são comumente associados com cereais e leguminosas, invadindo-os antes da colheita (PITT; HOCKING, 2009).

Fusarium é um dos três principais gêneros fúngicos produtores de toxinas. Os mais difundidos são os tricotecenos, sendo o mais importante o deoxinivalenol, produzido por $F$. graminearum, F. culmorum e espécies relacionadas. Zearalenona é outra micotoxina, produzida pelas mesmas espécies (PITT; HOCKING, 2009).

Espécies do gênero Fusarium, importantes fitopatógenos do trigo, necessitam para seu crescimento de Aa mínima de 0,87 e temperatura entre 0 e $39{ }^{\circ} \mathrm{C}$, com ótimo em $25{ }^{\circ} \mathrm{C}$ (LACEY; MAGAN, 1991). 
Mundialmente, a principal espécie associada aos grãos de trigo é $F$. graminearum (ALVAREZ et al., 2011; ASTOLFI et al., 2012; BRANCÃO et al., 2008; PANISSON; REIS; BOLLER, 2003), mas F. culmorum, F. boothii, F. cortaderiae, F. brasilicum, F. avenacum e F. meridionale também são encontrados (BOUTIGNY et al., 2011; LACEY; MAGAN, 1991; SCOZ et al., 2009).

As infecções causadas por este patógeno podem afetar tanto aspectos físicos quanto fisiológicos da semente, incluindo o seu tamanho, peso, composição e qualidade (BECHTEL et al. 1985), permitindo que ocorram severas perdas no rendimento, as quais podem ser superiores a 50\%, além de afetar a qualidade dos grãos susceptíveis (SNIJDERS, 1990).

\subsubsection{Fusarium graminearum}

Fusarium graminearum é um ascomiceto que produz esporos sexuais (ascósporos) em um saco conhecido como asca. A fase assexual do fungo produz esporos denominados de macroconídios, derivados de células produtoras de conídios, as fiálides. Fiálides são massas agrupadas em formato de almofadas conhecidas como esporodóquios. Os macroconídios são hialinos, em formato de canoa, normalmente com cinco ou mais septos (Figura 5) (AMERICAN PHYTOPATHOLOGICAL SOCIETY, 2012).

Figura 5 - Macroconídios (seta acima), fiálides (seta no centro) e esporodóquio (seta abaixo) de Fusarium graminearum.

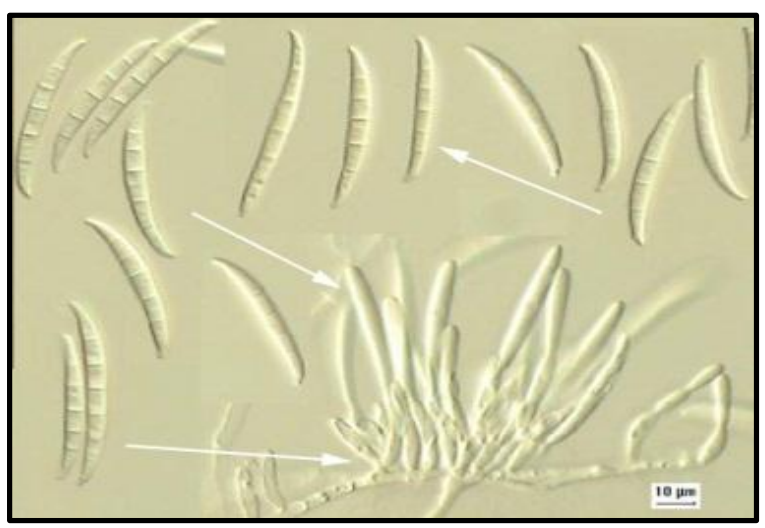

Fonte:APSnet 
Tabela 1 - Características morfológicas de conídios das espécies isoladas pertencentes ao complexo Fusarium graminearum.

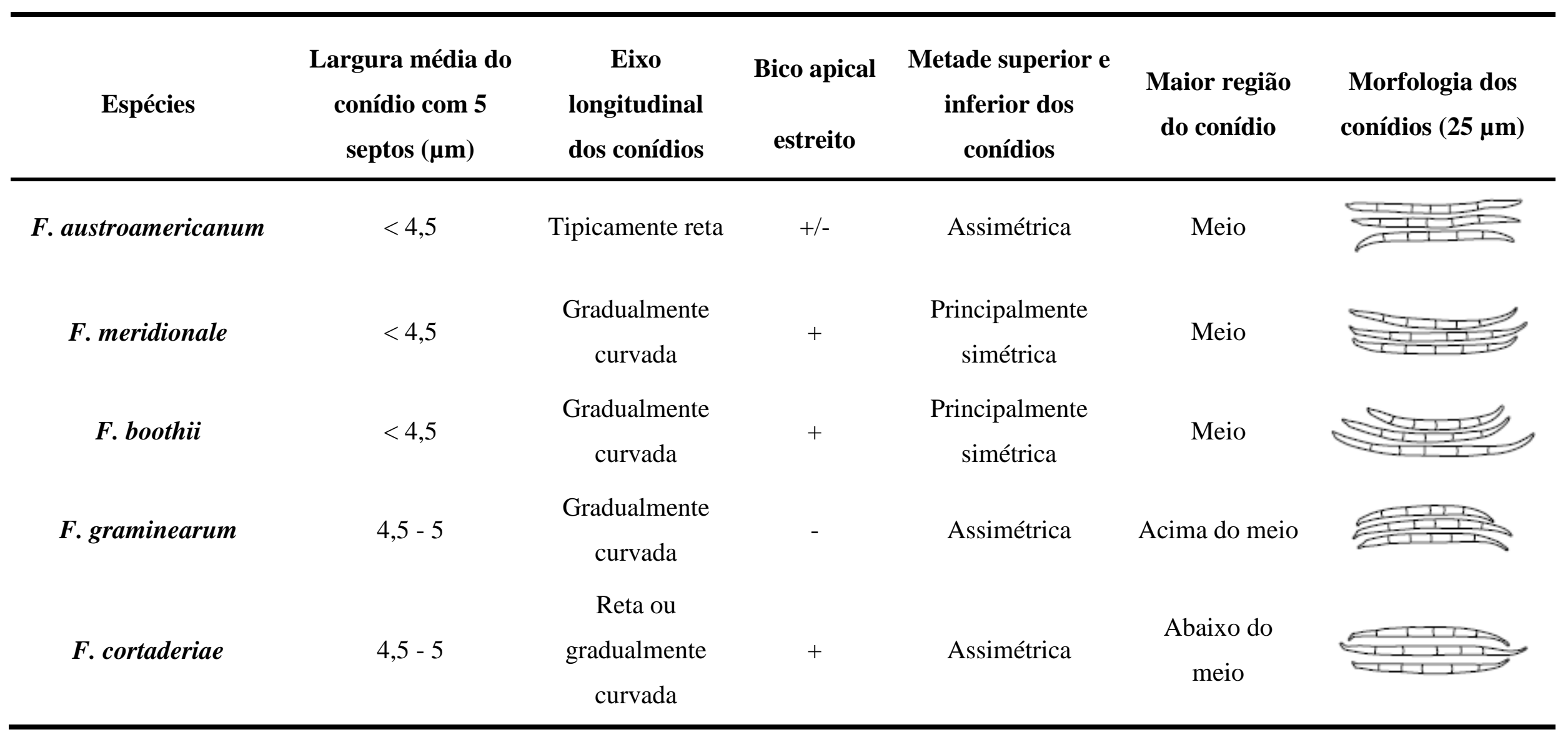

Fonte: O'Donnell et al., 2004. 
$\mathrm{O}$ anamorfo (estágio assexual) do fungo é Fusarium graminearum enquanto o teleomorfo (estágio sexual) do fungo é Gibberella zeae. O gênero Gibberella pertence à família Hypocreaceae, caracterizada por apresentar peritécios de coloração brilhante e que frequentemente se formam em um estroma (estruturas somáticas onde os corpos de frutificação se desenvolvem). Os ascósporos (esporos sexuais) se formam dentro de sacos conhecidos como ascas, e são forçadamente liberados do peritécio através de uma pequena abertura conhecida como ostíolo (Figura 6). Os ascósporos variam de hialinos a coloração castanha, levemente curvados e arredondados nas extremidades (Figura 6). A maioria dos isolados de $F$. graminearum são homotálicos, o que significa que eles são capazes de se reproduzir sem um parceiro (APSnet, 2012).

Figura 6 - (a) Seção transversal de um peritécio de Gibberella zeae apresentando ostíolo (seta acima) e ascas com ascósporos (seta abaixo). (b) Ascósporos de Gibberella zeae são levemente curvados e com as extremidades arredondadas.
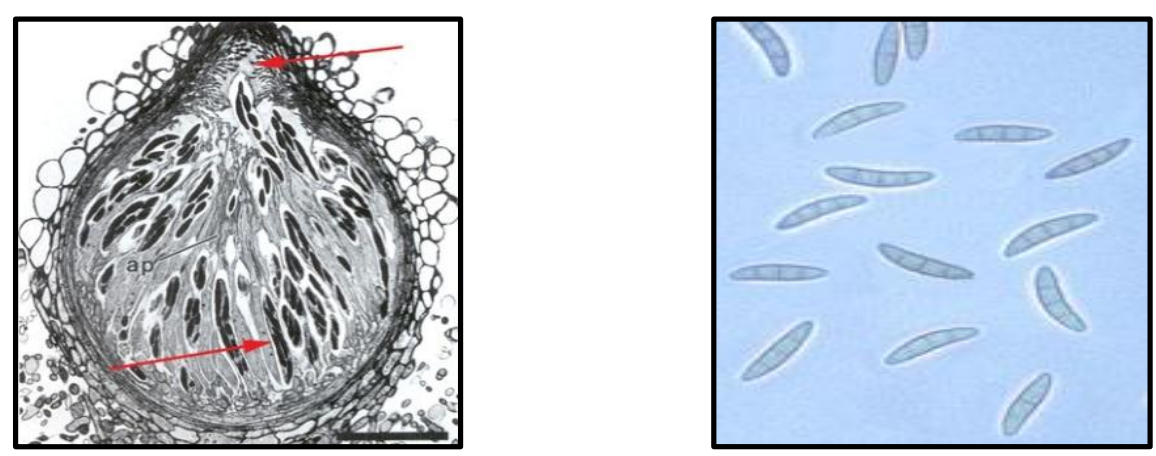

Fonte: APSnet

As condições climáticas das regiões produtoras de trigo, principalmente o sul do país, de clima subtropical úmido, e a adoção de plantio extensivo direto favorecem o aparecimento de doenças importantes desta cultura, dentre elas a fusariose ou giberela (FHB), causada principalmente pelo fungo Fusarium graminearum Schwabe. (ANGELOTTI et al., 2006; CALORI-DOMINGUES et al., 2007), embora espécies como Fusarium culmorum e Fusarium avenaceum sejam importantes em algumas regiões (BOTTALICO; PERRONE, 2002; MCMULLEN; JONES; GALLEMBERG, 1997). Na região sul, FHB tem sido associada a duas espécies do complexo de Fg: Fusarium graminearum sensu stricto e Fusarium meridionale; cada uma possuindo um genótipo de tricotecenos distinto (ASTOLFI et al. 2011, 2012; SCOZ et al., 2009). 
De importância mundial, a giberela é uma doença de difícil controle, sendo quase sempre devastadora (BRASIL, 2011f). A doença ataca as espigas, causando despigmentação das espiguetas afetadas; e chocho, enrugamento e coloração branco-rosada a pardo-clara nos grãos (LIMA, 2002). Atinge não somente a produção de trigo como outros grãos de cereais (MCMULLEN; JONES; GALLEMBERG, 1997; WINDELS, 2000) e resulta em produção de grãos e qualidade reduzidas, além da produção de micotoxinas (DESJARDINS, 2006; MORGAVI; RILEY, 2007).

\subsubsection{Alternaria spp.}

Os fungos do gênero Alternaria são os microrganismos mais comumente encontrados no ambiente agrícola (GRABARKIEWICZ-SZCZENA; CHELKOWSKI; ZAJKOWSKI 1989) sendo responsável pelo menos por cerca de $20 \%$ da deterioração dos produtos. Existem cerca de 299 espécies pertencentes a este gênero (KIRK et al., 2008), a maioria das quais são patógenos de plantas (STRANDBERG, 1992) e inclui também espécies saprofíticas.

As espécies do gênero Alternaria estão amplamente distribuídas na natureza e invadem cereais, oleaginosas e outras culturas, durante a maturação e a colheita. Muitos estudos têm reportado que Alternaria spp. é um dos principais, senão o principal componente da micobiota de trigo (AZCARATE et al., 2008; LI; YOSHIZAWA, 2000).

A espécie Alternaria alternata frequentemente ocorre em grãos de cereais. É a mais comum em grãos de trigo, podendo ser detectada em cerca de $100 \%$ dos grãos no momento da colheita (BENSASSI et al., 2009; HILL; LACEY, 1983; MAGAN; LACEY, 1984; PERELLÓ; MORENO; SISTERNA, 2008). Infecções por Alternaria alternata levam à descoloração preta ou marrom dos grãos resultando em diminuição da qualidade, rendimento viabilidade e o valor econômico e nutricional das colheitas (MAGAN; LACEY 1984; RODRIGUEZ-HERRERA; WANISKA; ROONEY, 1999).

Alternaria alternata, a espécie mais toxigênica do gênero, é um fungo pertencente à família Dematiaceae com fase sexuada ainda não descrita. Morfologicamente, a superfície das suas colônias é rugosa e os bordos são irregulares de coloração acinzentada a preta, variável de acordo com o substrato no qual se desenvolveram. Suas hifas são pigmentadas (escuras), retas ou flexuosas. Produz grandes conídios castanhos, formados em cadeia, com septos longitudinais e transversais com um distinto estreitamento cônico ou bico na extremidade apical (Figura 7) (PITT; HOCKING, 2009). 
Figura 7 - Conídios de Alternaria alternata.

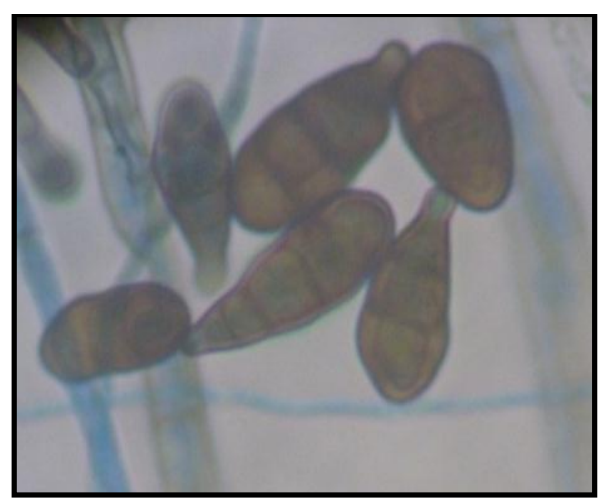

O gênero Alternaria é também conhecido pela sua periculosidade para humanos e animais pois algumas espécies apresentam elevado potencial toxigênico e capacidade de produzirem compostos tóxicos como as micotoxinas (LOGRIECO et al., 2003; WOODY; CHU, 1992). Pelo menos 20 espécies de Alternaria sp. são conhecidamente produtoras de cerca de 30 metabólitos tóxicos. A habilidade de A. alternata em produzir muitas micotoxinas diferentes pode explicar o grande interesse pela espécie (BARKAI-GOLAN; PASTER, 2013).

\subsection{MICOTOXINAS}

Micotoxinas são metabólitos secundários de fungos filamentosos com propriedades tóxicas que induzem vários efeitos nocivos e cancerígenos quando alimento contaminado com estes componentes é ingerido. As micotoxinas são produzidas por várias espécies de fungos e são conhecidas por sua mutagenicidade, carcinogenicidade e teratogenicidade, podendo afetar a saúde de humanos e animais, com efeito cumulativo (PESTKA, 2010). São moléculas de peso molecular reduzido e são específicas, geneticamente, de um grupo de espécies dentro de cada gênero fúngico (SANTOS, 2011).

Atualmente cerca de 400 tipos de micotoxinas são conhecidas, no entanto, apenas 30 foram detalhadamente estudadas (ETZEL, 2002). Algumas das micotoxinas mais conhecidas são: aflatoxinas, ocratoxinas, tricotecenos, fumonisinas, zearalenona, alternariol e patulina.

As micotoxinas são de ocorrência universal, porém predominam em climas tropicais e subtropicais, nos quais o desenvolvimento fúngico é favorecido pelas condições ambientais (MALLMANN; DILKIN, 2007).

A ocorrência de micotoxinas em agricultura depende das condições sob as quais uma safra em particular cresceu, foi colhida ou armazenada. As micotoxinas são estáveis na 
maioria das condições de processamento e apresentam alta estabilidade durante o armazenamento e processamento do alimento (WIDESTRAND; PETTERSSON, 2001) e desta forma, persistem até o produto final, resistindo inclusive a tratamentos culinários (SOBROVA et al., 2010).

A produção de micotoxinas depende do crescimento fúngico, portanto pode ocorrer em qualquer época de cultivo, colheita ou estocagem dos alimentos, podendo permanecer no grão mesmo depois que os fungos responsáveis pela produção não estejam mais presentes (TANIWAKI; SILVA, 2001). As micotoxinas podem formar-se no final da fase exponencial ou no início da fase estacionária do crescimento do bolor (GIMENO, 2010).

O desenvolvimento de fungos toxigênicos, com consequente produção de micotoxinas, depende de uma série de fatores, tais quais: (a) susceptibilidade do substrato à colonização do fungo produtor; (b) fatores físicos adequados como temperatura, umidade do substrato, umidade relativa do ar durante o armazenamento, aeração, danos mecânicos e tempo de armazenamento; (c) fatores biológicos como capacidade genética do fungo na produção de micotoxinas, quantidade de esporos viáveis, interação de diferentes fungos no mesmo substrato, interação de micotoxinas e presença de insetos nos grãos armazenados (CIEGLER, 1978; CRUZ; MANSILLA; TADEO, 2010; MALLMANN; DILKIN, 2007). Dentre estes desencadeadores, o tipo de substrato, os índices de umidade e de temperatura são os que mais influenciam a produção de micotoxinas (CORRÊA, 2000).

A importância do estudo das micotoxinas deve-se aos problemas gerados tanto à saúde pública quanto à economia. Entre as consequências da contaminação micotoxicológica de alimentos e bebidas estão: as perdas diretas dos produtos agrícolas, a redução do valor nutricional dos produtos, as patologias animais, os danos à saúde humana e o comprometimento das relações comerciais entre países (DAMBRÓS, 2013).

\subsubsection{Deoxinivalenol}

Os tricotecenos (12,13-epoxytrichothe-cenos) são um grupo de mais de 180 micotoxinas (MALEKINEJAD et al., 2007) que são estruturalmente relacionados com uma estrutura sesquiterpeno. São constituídos por um núcleo tricíclico e normalmente contém um epóxido no C-12 ou C-13, que é essencial à sua toxicidade. A sua estrutura química é variável de acordo com o número, posição e complexidade das esterificações, assim como pelo número de hidroxilações (MARQUES, 2007). 
Os tricotecenos são micotoxinas fortemente citotóxicos para as células eucarióticas (MARQUES, 2007), com potente ação inibidora na síntese de RNA (ácido ribonucleico) e DNA (ácido desoxiribonucleico) nas paredes celulares (SANTOS, 2011). Dentre os tricotecenos está o deoxinilvalenol (DON ou vomitoxina) cuja presença serve como indício de contaminação por outras micotoxinas (SOBROVA et al., 2010).

A fórmula empírica do DON é $\mathrm{C}_{15} \mathrm{H}_{20} \mathrm{O}_{6}$, sendo o seu nome químico 12,13-epoxy3a,7 $\alpha, 15$-trihydroxytrichothec-9-en-8-on (NAGY et al., 2005). O DON é muito estável a altas temperaturas, entre 170 e $350{ }^{\circ} \mathrm{C}$, sendo esta uma das suas propriedades físico-químicas mais importantes, aumentando muito o risco da sua permanência em alimentos. Temperaturas abaixo de $21{ }^{\circ} \mathrm{C}$ e chuva intensa são dois fatores que favorecem a contaminação das colheitas. (HUGHES et al., 1999). A Figura 8 esquematiza a estrutura do DON.

DON é um metabólito fúngico tóxico produzido por espécies do gênero Fusarium como F. graminearum e F. culmorum (PLACINTA; D’MELLO; MACDONALD, 1999). É uma substância comprovadamente teratogênica, neurotóxica, embriotóxico e de efeitos imunossupressores (PESTKA; SMOLINSKI, 2005; PESTKA, 2007). Estudos in vivo mostraram que, em doses baixas, causa dores abdominais, tonturas, dor de cabeça, náuseas, vômitos, diarréia e gastroenterite enquanto doses mais elevadas podem danificar gravemente linfóide e as células epiteliais da mucosa gastrointestinal, resultando em hemorragia e endotoxemia (PESTKA et al., 2004).

Como todos os tricotecenos, DON é inibidor da síntese de proteínas (FEINBERG; MACLAUGHLIN, 1989) e é especialmente tóxico para os porcos provocando vômitos, recusa alimentar e perda de devido a efeitos neurotóxicos (PITT; HOCKING, 2009).

Fusarium spp., fungo produtor de DON, pode crescer e produzir toxinas não só no campo, mas também após a colheita em condições desfavoráveis de armazenamento (MÜLLER et al., 1998). Durante o armazenamento, Birzele, Prange e Kramer (2000) encontraram um aumento nas concentrações de DON em amostras de trigo que foram cultivadas sob condições normais de cultivo.

\subsubsection{Zearalenona}

Zearalenona (ZEA) é uma micotoxina também produzida principalmente por espécies do gênero Fusarium (MANOVA; MLADENOVA, 2009), durante períodos prolongados de frio, elevada humidade e em épocas de colheita (ZINEDINE et al., 2007). 
ZEA é uma micotoxina estrogênica não esteroide (VEKIRU et al., 2010) cuja fórmula empírica é $\mathrm{C}_{18} \mathrm{H}_{22} \mathrm{O}_{5}$, correspondendo ao 6-(10-hidroxi-6-oxo-trans-1-undecenil)- $\beta$ - ácido resorcílico lactona, peso molecular 318,147. É estável e não se degrada a altas temperaturas. A representação da sua estrutura encontra-se na Figura 8.

Os efeitos tóxicos da ZEA derivam de suas propriedades estrogênicas, em humanos e animais através da sua ligação ao receptor de estrogênio natural (D’MELLO; PLACINTA; MACDONALD, 1999; ZINEDINE et al., 2007). É um disruptor endócrino e um substituto para as enzimas, resultando na síntese e inativação de hormônios (FINK-GREMMELS; MALEKINEJAD, 2007), podendo causar o desenvolvimento de câncer, mutações genéticas, nascimento defeituosos (JOSEPHS; SCHUHMACHER; KRSKA, 2001), alteração da morfologia do útero e infertilidade (ZINEDINE et al., 2007).

ZEA é uma das cinco melhor estudadas e das mais significativas micotoxinas (MILLER, 1995). Não é altamente tóxica e não foi associada a qualquer doença fatal nos animais ou seres humanos. No entanto, tem causado síndromes estrogênicas em suínos, e talvez em adolescentes humanos também. Porcos são especialmente sensíveis, demonstrando sinais de hiperestrogenismo na dieta com níveis > 1000 ppb, podendo ocorrer inclusive em níveis inferiores. Em leitoas pré-púberes, os sinais clínicos incluem inchaço vulvar, alargamento do útero e desenvolvimento mamário (HAGLER et al.,2001).

Figura 8 - Estrutura química das micotoxinas deoxinivalenol (à esquerda) e zearalenona (à direita).
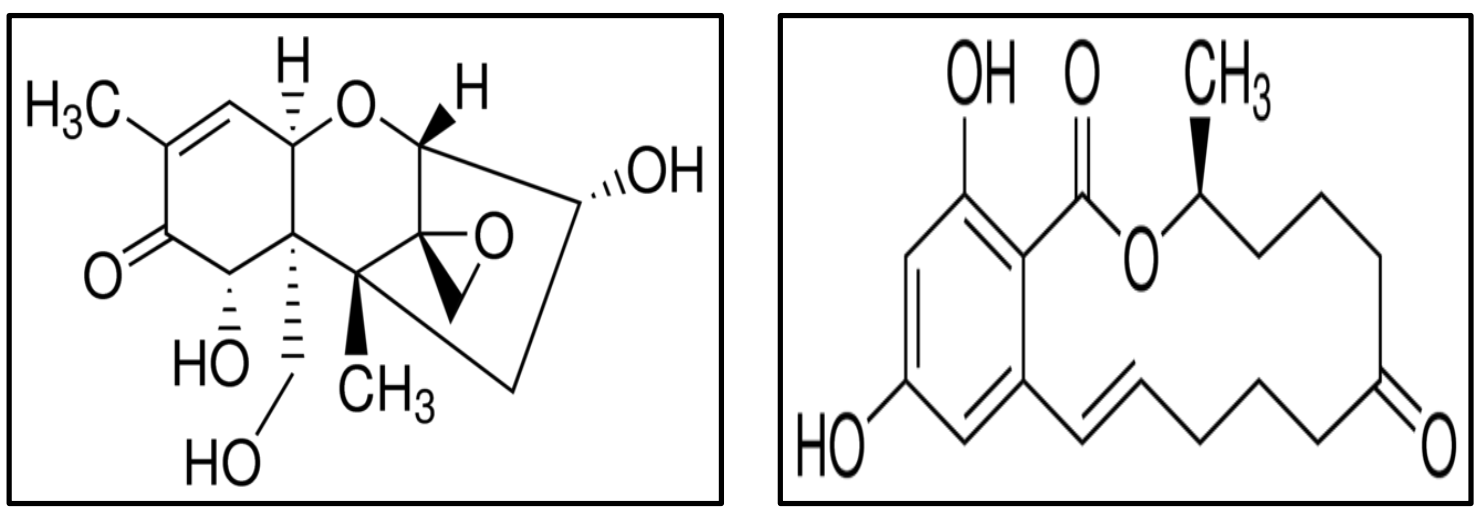

Fonte: Sigmaaldrich, 2012

As toxinas ZEA e DON já foram encontradas em diversos países, em diferentes cereais como: trigo, milho, arroz, aveia, cevada, soja, girassol, alfafa, sorgo (SOLEIMANY; JINAP; ABAS, 2012; AYALEW et al., 2006; MARQUES et al., 2008) e, como são 
produzidas pelo mesmo gênero fúngico, Fusarium spp., elas freqüentemente co-ocorrem em grãos (BRENN-STRUCKHOFOVA et al., 2009).

\subsubsection{Alternariol}

Alternariol $(\mathrm{AOH})$ é dibenzopyrone derivados (3,7,9-tri-hidroxi-1-metil-6H-benzo [c] cromen-6-ona) e foi primeiramente descrito em 1953 por Raistrick, Stickings e Thomas a partir de Alternaria tenuis.

Figura 97 - Estrutura química do alternariol.

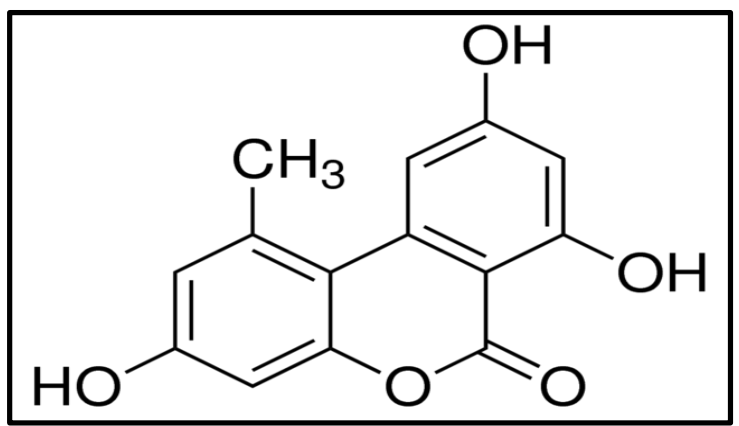

Fonte: Sigmaaldrich, 2012

AOH é produzido por A. tenuissima, A. brassicae, A. capsici-annui, A. citri, A. cucumerina, A. dauci, A. kikuchiana, A. longipes, A. porri, A. solani e A. tomato (BARKAIGOLAN; PASTER, 2013).

Segundo alguns autores, em condições favoráveis de temperatura e umidade, Alternaria spp. pode produzir até 71 micotoxinas (CHULZE et al., 1995; MONTEMURRO; VISCONTI, 1992). Em alimentos, a espécie A. alternata é potencialmente produtora de sete toxinas, destacando-se o alternariol $(\mathrm{AOH})$, o alternariol monometil éter (AME), altenueno (ALT) e o ácido tenuazônico (TA) como as mais estudadas (GRECO et al., 2012; LI; YOSHIZAWA, 2000; PATRIARCA et al., 2007).

A toxina foi encontrada em uma variedade de commodities agrícolas como centeio, trigo, mirtilo, milho, maçãs e tomates, em diferentes países (AZCARATE et al., 2008; GRABARKIEWICZ-SZCZENA; CHELKOWSKI; ZAJKOWSKI, 1989, GRECO et al., 2012; MONBALIU et al., 2010; SCOTT, 2001) e, apesar de não ser muito tóxica, quando associada com outras micotoxinas, apresenta efeitos sinérgicos e os efeitos tóxicos são agudos (MOTTA; SOARES, 2000). 
As micotoxinas produzidas por Alternaria spp. contaminam muitos produtos agrícolas e são consideradas como causa potencial de câncer, complicações no sistema digestivo e dificuldades respiratórias (CHU, 1991; POHLAND, 1993; DONG et al., 1987; ZUREIK et al, 2002).

AOH, AME e ALT são substâncias citotóxicas, teratogênicas, mutagênicas, clastogênicas, oncogênica, estrogênicas em sistemas de células microbianas e de mamíferos, tumorigênicas e inibidoras da proliferação de células em ratos (BRUGGER et al., 2006; LEHMANN; WAGNER; METZLER, 2006; LIU et al., 1992; LOGRIECO; MORETTI; SOLFRIZZO 2009; TIEMANN et al., 2009).

Estudos recentes têm chamado a atenção para o efeito crônico e subagudo do $\mathrm{AOH}$. Marko (2007) e Fehr et al. (2009) caracterizaram a atuação desta micotoxina como um veneno à topoisomerase, induzindo à quebra das cadeias de DNA. Nos estudos in vitro revelou-se que o $\mathrm{AOH}$ inibe a síntese de progesterona afetando o desempenho reprodutivo (TIEMANN et al., 2009). Apresenta fetotoxicidade em ratos e hamsters (VISCONTI; SIBILIA, 1994)

Apesar do gênero Alternaria ser um importante patógeno de plantas, um dos principais fungos encontrados em grãos e capaz de produzir toxinas, os registros na literatura dos níveis, da frequência de contaminação e da co-ocorrência das micotoxinas de Alternaria em cereais em todo o mundo ainda têm sido muito limitados, principalmente no Brasil.

A carência de estudos envolvendo micotoxinas de Alternaria spp.em trigo e as novas descobertas toxicológicas, motivaram o estudo de $\mathrm{AOH}$ na presente investigação.

Além disso, processos de antagonismo, competição ou coexistência entre diferentes fungos já foram descritos (JÚNIOR; VECHIATO; MENTEN, 2008; LACEY et al., 1991; MÜLLER et al, 2012;. SINGH LAKHESAR; BACKHOUSE; KRISTIANSEN, 2010; XU; NICHOLSON, 2009), nos quais se identificou a co-ocorrência de alguns fungos como Alternaria spp. e Fusarium spp. Portanto, a co-ocorrência de micotoxinas por estes produzidas pode ser esperada, causando efeitos antagônicos, sinérgicos ou aditivos e um risco de agravar os efeitos tóxicos já que os compostos atuam no mesmo local e com o mesmo mecanismo de ação (COPPOCK; CHRISTIAN, 2007).

Geralmente, pode concluir-se que a exposição a várias classes de micotoxinas resulta em um efeito aditivo (MONBALIU et al., 2010). A possibilidade de co-ocorrência de micotoxinas em alimentos suscita preocupações acrescidas, uma vez que é ainda muito limitado o estudo dos efeitos das interações entre estes compostos. (SANTOS, 2011). 
Portanto, o estudo das toxinas em conjunto é de grande importância tendo em vista a obtenção de uma melhor avaliação da co-ocorrência natural de várias micotoxinas. Os dados de frequência e quantidade de micotoxinas em cereais são requisitos fundamentais para a estimativa dos riscos toxicológicos e para o controle por parte das agências fiscalizadoras.

\subsection{OCORRÊNCIA EM TRIGO E DERIVADOS}

Segundo o Conselho de Ciência Agrícola e Tecnologia (CAST, 2003), colheitas de todos os tipos são frequentemente contaminadas com micotoxinas, sendo que $25 \%$ da alimentação mundial apresentam-se contaminadas com estes metabólitos secundários.

A Tabela 2 mostra alguns estudos sobre ocorrências de DON, ZEA e AOH em trigo e derivados realizado em vários países.

No Brasil, até o presente momento, foram relatados quatro estudos envolvendo DON e ZEA. Em 1992, Furlong, analisando amostras de trigo, provenientes de São Paulo e Rio Grande do Sul, constatou a apresença de DON e ZEA em 55\% e 15\% das amostras analisadas, respectivamente. A presença simultânea de outras micotoxinas também foi observada.

Furlong et al. (1995), verificaram contaminação de amostras de trigo, 20\% com DON (470-590 ppb) e 15\% com ZEA (40-210 ppb).

Estudo realizado por Oliveira et al. (2002) sobre a incidência de DON em produtos de panificação, farinha e farelo de trigo de Minas Gerais, detectou a toxina em 32 (68\%) das 47 amostras analisadas (40 a $1205 \mathrm{ppb}$ ).

Posteriormente, em 2007, Calori-Domingues et al., realizando estudo comparativo entre o trigo brasileiro e argentino, constatou a presença de DON em 94\% (47/50) das amostras de trigo produzidos no Brasil, com níveis médios de 332 ppb. 
Tabela 2 - Levantamento sobre algumas ocorrências de DON, ZEA e AOH em trigo e derivados realizado em vários países.

\begin{tabular}{|c|c|c|c|c|c|c|}
\hline Região & Toxina & Amostra & $\begin{array}{l}\text { Número de } \\
\text { amostras }\end{array}$ & $\begin{array}{c}\text { Amostras } \\
\text { contaminadas }\end{array}$ & Nível (ppb) & Referência \\
\hline \multirow{3}{*}{ Etiópia } & DON & & 23 & $17,4 \%$ & $50-110$ & Ayalew et al., \\
\hline & & Trigo & & & & \\
\hline & ZEA & & 16 & 0 & 0 & 2006 \\
\hline \multirow{3}{*}{ Quenia } & DON & & & $68 \%$ & $105-303$ & Muothomi et al., \\
\hline & & Trigo & 82 & & & \\
\hline & ZEA & & & $57 \%$ & $1-96$ & 2008 \\
\hline \multirow{5}{*}{ Europa } & DON & & & $63 \%$ & $74-9528$ & \multirow{5}{*}{ Monbaliu et al., } \\
\hline & & & & & & \\
\hline & ZEA & Trigo e milho & 82 & $14 \%$ & $58-387$ & \\
\hline & & & & & & \\
\hline & $\mathrm{AOH}$ & & & $4 \%$ & $17-25$ & \\
\hline \multirow{3}{*}{ México } & DON & & & $69,6 \%$ & $100-20000$ & González-Osnaya; Farrésa \\
\hline & & Trigo & 30 & & & \\
\hline & ZEA & & & $45,7 \%$ & $73-1000$ & 2011 \\
\hline
\end{tabular}




\begin{tabular}{|c|c|c|c|c|c|c|}
\hline Região & Toxina & Amostra & $\begin{array}{l}\text { Número de } \\
\text { amostras }\end{array}$ & $\begin{array}{c}\text { Amostras } \\
\text { contaminadas }\end{array}$ & Nível (ppb) & Referência \\
\hline \multirow{3}{*}{ Malásia } & DON & & & $50 \%$ & $22,8-112,5$ & Soleimany, Jinap e Abas, \\
\hline & & Trigo & 20 & & & \\
\hline & ZEA & & & $30 \%$ & $1,42-12,74$ & 2012 \\
\hline \multirow[t]{2}{*}{ Sérvia } & & Trigo & 103 & & & \\
\hline & ZEA & & & $91,6 \%$ & $10-201$ & 2012 \\
\hline Canadá & $\mathrm{AOH}$ & Derivados & 83 & $84,3 \%$ & $0,4-63$ & $\begin{array}{l}\text { Scott et al., } \\
2012\end{array}$ \\
\hline Japão & & Trigo & 22 & $90,9 \%$ & $116-731$ & 2000 \\
\hline Argentina & $\mathrm{AOH}$ & Trigo & 64 & $6 \%$ & $645-1388$ & $\begin{array}{c}\text { Azcarate et al., } \\
2008\end{array}$ \\
\hline Alemanha & $\mathrm{AOH}$ & Trigo & 1064 & $8,1 \%$ & $10-831,7$ & Müller; Korn, 2013 \\
\hline
\end{tabular}




\begin{tabular}{|c|c|c|c|c|c|c|}
\hline Região & Toxina & Amostra & $\begin{array}{l}\text { Número de } \\
\text { amostras }\end{array}$ & $\begin{array}{c}\text { Amostras } \\
\text { contaminadas }\end{array}$ & Nível (ppb) & Referência \\
\hline \multirow{3}{*}{ Brasil } & DON & & & $55 \%$ & $470-580$ & Furlong, \\
\hline & & Trigo & 38 & & & \\
\hline & ZEA & & & $15 \%$ & $40-210$ & 1992 \\
\hline \multirow[t]{2}{*}{ Brasil } & & Trigo & 20 & & & \\
\hline & ZEA & & & $15 \%$ & $40-210$ & 1995 \\
\hline Brasil & DON & Farinha de trigo, & 47 & $68 \%$ & $40-1205$ & Oliveira et al., \\
\hline \multirow{2}{*}{ Brasil } & DON & Trigo & 50 & $94 \%$ & $90-4573$ & \\
\hline & & & & & & 2007 \\
\hline
\end{tabular}




\subsection{CROMATOGRAFIA LÍQUIDA DE ALTA EFICIÊNCIA ACOPLADA À ESPECTROMETRIA DE MASSAS SEQUENCIAL}

Muitos métodos analíticos têm sido desenvolvidos e aplicados em todo o mundo a fim de controlar a incidência de micotoxinas e/ou minimizar a exposição de homens e animais aos efeitos tóxicos aos quais poderiam estar submetidos.

$\mathrm{O}$ fato de que a maioria das micotoxinas são tóxicas em concentrações muito baixas, torna necessário dispor de métodos sensíveis e confiáveis para a sua detecção (CRUZ; MANSILLA; TADEO, 2010). A determinação das toxinas pode ser realizada através de cromatografia em camada delgada (CCD), cromatografia gasosa (CG) ou cromatografia líquida de alta eficiência (CLAE) com detecção por ultravioleta (UV), por fluorescência (FLD), ou arranjo de diodo (DAD). Porém a detecção por espectrômetro de massas (MS), por ser mais sensível e mais eficiente na análise de traços, é a técnica mais adequada para essa finalidade.

Como diferentes micotoxinas podem estar presentes na mesma matriz, métodos analíticos para a determinação simultânea de diferentes micotoxinas têm sido desenvolvidos recentemente em cereais, inclusive em trigo (SOLEIMANY; JINAP; ABAS, 2012; MONBALIU et al., 2010).

A determinação de contaminantes em matrizes complexas, como alimentos, geralmente requer extensiva e morosa preparação e extração da amostra antes da análise propriamente dita. A quantidade de preparo de amostra necessária é dependente das propriedades químicas da matriz e do analito, do nível a ser detectado e da metodologia analítica utilizada para análise (TURNER; SUBRAHMANYAM; PILETSKY, 2009). A maioria dos procedimentos analíticos para a determinação de micotoxinas têm as seguintes etapas em comum: amostragem, homogeneização, extração e purificação que pode incluir concentração da amostra.

O estudo e a determinação de contaminantes em alimentos que podem causar impactos a saúde humana têm encontrado na espectrometria de massas uma grande ferramenta de aplicação (CARERI; BIANCHI; CORRADINI, 2002).

Atualmente, a espectrometria de massa (MS - Mass Spectrometry) é uma das mais importantes ferramentas analíticas disponíveis, utilizada para obter informação sobre: a composição elementar de amostras; peso e estrutura molecular; a composição qualitativa e quantitativa de misturas complexas, análises quantitativas de substâncias a nível traço e as proporções isotópicas de átomos em amostras (AGILENT, 2001). 
A cromatografia líquida acoplada a detectores de massas resulta em uma poderosa ferramenta em análise alimentar devido à capacidade de separação da cromatografia combinadas a alta sensibilidade e seletividade do espectrômetro de massas. A especificidade resulta da capacidade do espectrômetro medir a massa do composto. Já a sensibilidade deste instrumento resulta da eficiência do detector em detectar a chegada de um simples íon (GRANDE; NETO, 1990).

$\mathrm{Na}$ espectrometria de massa, alguma forma de energia é transferida à amostra para causar a sua ionização, através da formação de íons livres em fase gasosa.

Figura 10 - Ilustração do fundamento da Espectrometria de Massas.

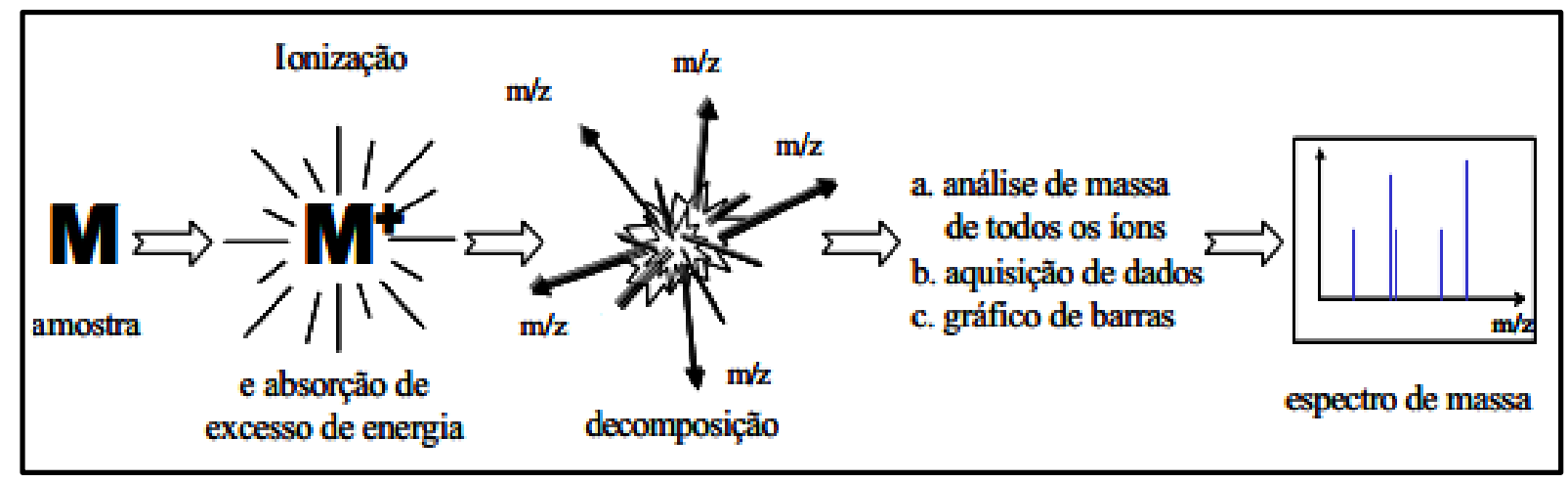

São três os componentes principais de um espectrômetro de massas: uma fonte de íons, o analisador ou filtro de massas (na realidade $\mathrm{m} / \mathrm{z}$ ) e o detector. A fonte de íons tem a finalidade de gerar os íons a serem analisados na fase gasosa a partir das amostras de interesse. $\mathrm{O}$ analisador de massas emprega combinações entre campos elétricos e magnéticos para separar os íons gerados na fonte de ionização de acordo com as suas razões massa/carga $(\mathrm{m} / \mathrm{z})$. O detector tem a finalidade de quantificar os íons provenientes do analisador de massas e convertê-los em sinais eletrônicos (MARTINS JÚNIOR, 2005).

\subsubsection{Ionização: Electrospray (ESI)}

É um método de ionização sensível e altamente acoplável a técnicas de cromatografia líquida, útil para a maioria das classes de compostos.

Electrospray é uma técnica de ionização a pressão atmosférica em que uma pequena quantidade de energia é transferida para as móleculas da substância a ser analisada, permitindo a geração de espécies carregadas do analito com pequena ou nenhuma 
fragmentação da molécula ionizada (MARTINS JÚNIOR, 2005) Gera-se um aerossol diminuto através do acúmulo de carga eletrostática. O fluxo de fase móvel, vindo do cromatógrafo, passa em uma câmara onde existe um fluxo de gás aquecido, por um capilar de pequeno diâmetro alimentado por uma diferença de potencial de poucos $\mathrm{kV}$, gerando um campo eletrostático. O campo elétrico criado induz o acúmulo de carga na superfície do líquido no final do capilar, formando gotículas carregadas. O gás aquecido auxilia na evaporação do solvente. O solvente evapora da gotícula carregada tornando-a instável pelo acúmulo de carga. Quando o acúmulo de carga torna-se maior que a tensão superficial da gota, ocorre um fenômeno chamado explosão de Coulomb. A molécula do analito retém a carga da gotícula tornando-se um íon após a vaporização do solvente (CROTTI, 2006). O spray inicia com a aplicação de uma voltagem dependente da tensão superficial de cada solvente.

A ionização pode ser feita em modo positivo ou negativo. Para a ionização em modo positivo, ocorre o fornecimento de elétrons para a molécula neutra (oxidação), enquanto que no modo negativo (potencial negativo) os elétrons são retirados da molécula (redução):

$$
\begin{array}{ll}
\mathrm{M} \rightarrow \mathrm{M}^{+}+\mathrm{e}^{-} & \text {(oxidação) } \\
\mathrm{M}^{+}+\mathrm{e}^{-} \rightarrow \mathrm{M} & \text { (redução) }
\end{array}
$$

Durante a fissão a gotícula perde uma pequena porcentagem de sua massa juntamente com uma porcentagem relativamente alta de sua carga. As gotículas menores seguem o ciclo de evaporação do solvente e fissão, resultando no íon livre final (KLITZKE, 2013).

\subsubsection{Analisador de Massas: Quadrupolo}

É um dos analisadores mais utilizados em espectrometria de massas, responsável por filtrar os íons com base na relação m/z. Os íons são separados com base na estabilidade de suas trajetórias em um campo elétrico sendo este criado por oscilações elétricas apliacadas nos quatro cilindros metálicos dispostos entre si em forma de cruz. Os íons produzidos são focalizados ao centro, entre os cilindros, e atravessam o quadrupolo axialmente, alternando a posição entre os pólos (dois positivos e dois negativos). Apenas íons de uma particular $\mathrm{m} / \mathrm{z}$ terão trajetórias estáveis e chegarão ao detector e isto é definido pelo potencial aplicado. Idealmente o analisador deveria ser capaz de distinguir diferenças de massa mínimas (alta resolução) (AGILENT, 2001). 
Figura 118 - Esquema ilustrativo do funcionamento de um espectrômetro de massas.
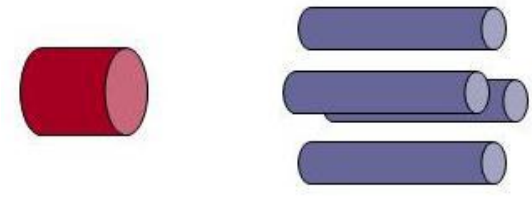

Ionização

Eletrospray

(ESI)

Q1

Seleção de $\mathbf{m} / \mathbf{z}$ do analito

$[\mathrm{MH}]^{+}$

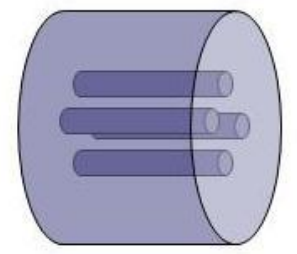

Q2

Fragmentação

Célula de

colisão

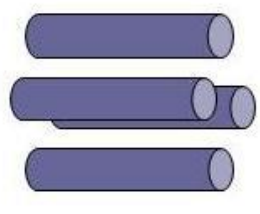

Q3

Seleção de $\mathbf{m} / \mathbf{z}$ do íon fragmento do analito

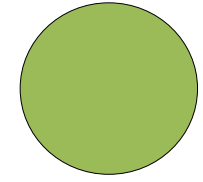

Detector

Triplo

Quadrupolo

Os analitos são

O íon

Úm único íon é

Ìon produto é

Eixo

ionizados após

precursor

transmitido rápida

separado de

triplo

separação

alvo é isolado

e eficientement

interferências

cromatográfica

dos íons de

pela dissociação do

matriz

íon precurssor
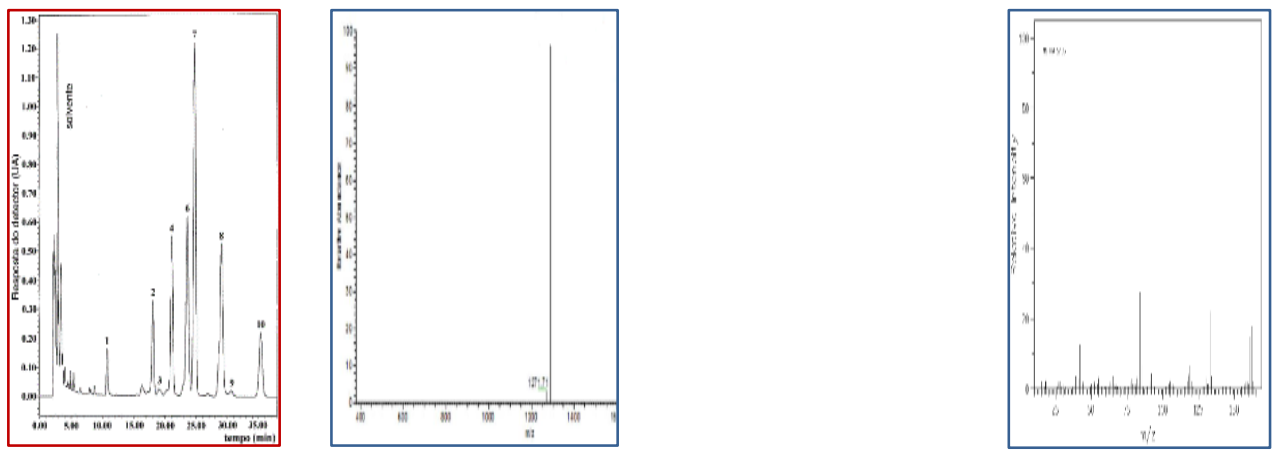

Envolve a geração de íons produtos, formados a partir da fragmentação de um íon precursor, previamente selecionado, após este sofrer aplicação de uma energia de colisão. $\mathrm{O}$ processo de fragmentação de um íon de $\mathrm{m} / \mathrm{z}$ específica requer o isolamento deste íon e dos íons produtos, realizado por quadrupolos analisadores de massas (DAMBRÓS, 2013).

Em um sistema triploquadrupolo, três quadrupolos são dispostos sequencialmente (espectrometria de massas sequencial). $\mathrm{O}$ primeiro quadrupolo opera selecionando 
determinado íon (chamado íon precursor) gerado na fonte de ionização do instrumento. $\mathrm{O}$ segundo quadrupolo opera como uma cela de fragmentação do íon selecionado no primeiro quadrupolo (íons produto), gerando íons fragmento característicos, similar a uma impressão digital. No terceiro quadrupolo, ocorre novamente uma seleção dos íons gerados na cela de fragmentação baseado na relação $\mathrm{m} / z$ (AGILENT, 2001; APPLIED BIOSYSTEMS, 2005).

O espectro de massas corresponde a distribuição de sinais consecutivos que correspondem a população de íons com diferentes cargas obtidas por protonação $[\mathrm{M}+\mathrm{H}]^{+}$ou desprotonação $[\mathrm{M}+\mathrm{H}]^{-}$.

Dessa forma, na fonte de íons, os componentes de uma amostra são convertidos em íons (positivos ou negativos), pela ação de um agente ionizante, que são imediatamente acelerados em direção ao analisador de massa. A função do analisador de massa é separar tais íons de acordo com a sua relação massa-carga $(\mathrm{m} / \mathrm{z})$. Finalmente um detector recebe os íons que foram separados pelo analisador, transformando a corrente de íons em sinais elétricos que são processados e armazenados.

O espectrômetro de massas deve ser ajustado e calibrado, garantindo a melhor resposta para a amostra e os analitos abordados no estudo e são operações realizadas periodicamente utilizando uma solução padrão de calibração com massas conhecida com o objetivo de detectar os íons alvos o mais exato possível, com base na sua relação massa/carga, dentro de uma variação aceitável. Assim que o pico exato é identificado, ocorre o ajuste da resolução, para adquirir a melhor largura e forma do pico. Dessa forma, o desempenho do instrumento é maximizado e os parâmetros encontrados são utilizados por todos os experimentos realizados no instrumento (APPLIED BIOSYSTEMS, 2005).

A otimização do instrumento foca em sensibilidade para o analito de interesse, realizada quando se quer maximizar a resposta para determinado analito. A otimização é realizada ajustando os parâmetros dependentes da fonte (source-dependent parameters) e os parâmetros dependentes do composto (compound-dependent parameters), que não dependem das condições cromatográficas e irão guiar o íon dentro do espectrômetro de massas (APPLIED BIOSYSTEMS, 2005).

Para realização da otimização dos parâmetros composto-dependentes pode-se utilizar o método de infusão que consiste na introdução do analito na fonte de ionização, de modo contínuo utilizando uma bomba programada. Esta abordagem é geralmente utilizada quando se tem grandes quantidades de analito, usualmente um padrão analítico. Os parâmetros composto-dependentes que necessitam ser otimizados são: 
- Gás de colisão (CAD): este parâmetro controla a pressão do gás de colisão na cela de colisão. Em varredura MS/MS o gás de colisão atua realizando a fragmentação do íon precursor. Quando os íons precursores colidem com o gás de colisão eles geram fragmentos (os íons produto) que serão selecionados no terceiro quadrupolo.

- Declustering Potential (DP): o parâmetro DP controla a voltagem aplicada no orifício de entrada do espectrômetro de massas. Esta voltagem é utilizada para minimizar a formação de clusters de moléculas de solvente que podem permanecer após a entrada na região do vácuo ou para realizar a fragmentação dos íons antes de entrarem no espectrômetro de massas.

- Potencial de entrada (EP do inglês, entrance potential): esta voltagem controla a entrada e focalização dos íons para dentro do quadrupolo.

- Potencial de saída da cela de colisão (CXP do inglês, collision cell exit potential): esta voltagem controla a saída e focalização dos íons para fora da cela de colisão em direção ao quadrupolo seguinte.

Para realização da otimização dos parâmetros dependentes da fonte utiliza-se a análise por injeção em fluxo (FIA do inglês, flow injection analysis). Neste método, sucessivas injeções de uma pequena quantidade de analito são realizadas enquanto os parâmetros da fonte são variados (APPLIED BIOSYSTEMS, 2005). Os parâmetros variam de acordo com a fonte utilizada. Para uma fonte electrospray otimiza-se:

- Gás 1 (GS1): o parâmetro GS1 controla o gás de nebulização, o qual auxilia na geração de pequenas gotas a partir do fluxo do cromatógrafo, afetando a estabilidade e sensibilidade dos íons no spray.

- Gás 2 (GS2): o parâmetro GS2 controla o gás auxiliar na fonte de electrospray, o qual auxilia a evaporação das gotas no spray prevenindo que solvente entre no instrumento.

- Temperatura (TEM): o parâmetro TEM controla a temperatura do gás auxiliar no fonte electrospray, auxiliando a evaporação do solvente para produzir uma fase gasosa da amostra.

- Curtain Gas (CUR): este parâmetro controla o fluxo de gás na saída do orifício de entrada do espectrômetro de massas. A “cortina de gás” previne que moléculas de solvente entrem e contaminem o espectrômetro de massas. Deve ser mantido o mais alto possível sem que ocorra perda de sensibilidade. 
- Ionspray voltage (IS): este parâmetro controla a voltagem aplicada na agulha que ioniza a amostra na fonte. Ele depende da polaridade utilizada e afeta a estabilidade e sensibilidade dos íons no spray.

CLAE-MS/MS tornou-se a ferramenta analítica mais adequado para a determinação de micotoxinas e seus metabólitos. As vantagens deste instrumento incluem baixo limite de detecção, capacidade de gerar informação estrutural das substâncias analisadas, exigência de tratamento mínimo da amostra, a capacidade de abranger uma grande variedade de analitos que diferem nas suas polaridades e são detectores bastante gerais que não são tão dependentes de características químicas como fluorescência e absorção no UV.

Para evitar perdas dos analitos de interesse e redução subsequente de recuperação, a maioria dos métodos que envolvem espectrometria de massas utilizam procedimentos simples na preparação de amostra, eliminando etapas específicas de purificação, o que, além da facilidade do procedimento, apresenta economia de tempo, trabalho, resíduo, gastos e alta aplicabilidade para análises de rotina.

\subsection{FATORES ABIÓTICOS}

Os grãos de trigo colhidos podem se contaminar significativamente durante os estágios pós-colheita. Os fatores bióticos influenciam no crescimento fúngico e na produção de micotoxinas nos grãos como tipo de grão, maturação e espécie fúngica (MAGAN et al., 2010). Dentre os fatores abióticos que irão influenciar no nível de contaminação, destacam-se a quantidade de água livre disponível, expressa em atividade de agua (Aa) e a temperatura, sendo evidente a importância de avaliar o comportamento dos diferentes microrganismos frente a estes fatores (ALMEIDA et al., 2002).

A atividade de água (Aa) influencia significativamente o tempo de estocagem de um alimento e até mesmo sua utilização. A água é talvez o fator limitante mais importante para a colonização de grãos, determinando quais microrganismos são capazes de se desenvolver, a possibilidade de germinação do esporo fúngico, o metabolismo, a atividade respiratória e a taxa de crescimento. Os fungos são os microorganismos mais resistentes a baixa atividade de água e causam perda de matéria seca, perda de qualidade, diminuição no valor nutricional e na digestibilidade e produção de micotoxinas. Assim, a Aa é um fator intrínseco de grande importância na manutenção ou degradação de alimentos (PITT; HOCKING, 2009; TROLLER; BERNARD; SCOTT, 1984). 
A atividade de água de um alimento é a quantidade de água livre disponível, não comprometida com ligaçõesquímicas, dissolução de solutos e outros (TANIWAKI; SILVA, 2001). A Aa é um conceito químico definido como a relação entre a pressão de vapor de água de um determinado substrato e a pressão de vapor de água pura, nas mesmas condições (TROLLER; BERNARD; SCOTT, 1984), sendo expresso como na Equação 1:

$$
\mathrm{Aa}=\mathbf{p} / \mathbf{p 0}
$$

onde p é a pressão de vapor da solução, e p0 é a pressão de vapor do soluto

Os valores de Aa oscilam entre 0 e 1, sendo 1 o valor encontrado na água pura. Todos os fungos toxigênicos apresentam valores mínimo, ótimo e máximo de Aa e temperatura para seu crescimento (JAY, 1994); Em geral, o desenvolvimento ótimo dos fungos ocorre em temperaturas entre 25 e $30{ }^{\circ} \mathrm{C}$ (CARLILE; WATKINSON, 1994) e em uma atividade de água de 0,85 (TANIWAKI; SILVA, 2001).

Em geral, as espécies de Fusarium requerem uma elevada Aa para colonizar grão, geralmente acima de 0,90 (LACEY; MAGAN, 1991). F. graminearum é favorecido pela umidade contínua (mínimo de 24 horas) e temperaturas de 20-30 ${ }^{\circ} \mathrm{C}$ (DIEKMANN; PUTTER 1995).

A faixa de crescimento de Alternaria spp. varia de $6,5^{\circ} \mathrm{C}$ a $36^{\circ} \mathrm{C}$, sendo a temperatura ótima próxima de $25{ }^{\circ} \mathrm{C}$ (DOMSCH; GAMS; ANDERSON, 1980; HASIJA et al., 1970;). A atividade de água mínima para seu crescimento é 0,88 (HOCKING, 1994).

A infecção com fungos e a produção de micotoxinas está relacionada principalmente com as condições ambientais no campo. A toxina uma vez produzida permanece no grão após a colheita, podendo ocorrer um aumento nos níveis de contaminação dependendo das condições de armazenamento (ALMEIDA, 2006). As condições ótimas para a produção de micotoxinas em grãos infectados são dependentes do substrato, espécies e isolado, e é dependente principalmente de limites bem definidos de temperatura e atividade de água (DOOHAN; BRENNAN; COOKE, 2003).

Ramirez, Chulze e Magan (2006) relataram que a produção de DON, produzido por isolados de F. graminearum, em trigo variou consideravelmente dependendo da interação entre atividade de água e temperatura, sendo que a atividade de água ótima para o crescimento estava entre 0,95 e 0,99 e temperatura ótima $25^{\circ} \mathrm{C}$.

Sanchis e Magan (2004) relataram que a Aa limitante para a produção de micotoxinas (ALT, AME e AOH) por A. alternata em grãos de trigo varia entre 0,88 e 0,89. A maior 
produção de toxinas ocorre a $25^{\circ} \mathrm{C}$ e Aa maiores que 0,97. Magan e Lacey (1984) relataram que a redução da Aa de 0,98 para 0,95, reduziu em $40 \%$ a produção de micotoxinas reduziu $40 \%$. As toxinas foram produzidas mesmo a $5{ }^{\circ} \mathrm{C}$ com Aa $0,98-0,95$, e a $30{ }^{\circ} \mathrm{C}$ com Aa 0,98 a 0,90 .

Frequentemente as concentrações de zearalenona são baixas em grãos contaminados no campo, mas pode aumentar durante o armazenamento se a umidade for superior a $34 \%$ (WILSON; ABRAMSON, 1992).

Em 2000, Homdork, Fehrmann e Beck demonstraram que o conteúdo de DON nas amostras contaminadas por Fusarium spp. aumentou em amostras com nível de infecção ligeira $(4 \%)$ ou moderada (15\%) quando a semente foi armazenada sob condições quentes e úmidas.

\subsection{LEGISLAÇÃO}

A gestão da contaminação de grãos por micotoxinas é fundamental na qualidade e segurança do cereal. Devido à sua ocorrência freqüente e às conseqüências para a saúde humana, vários países têm estabelecido limites para a concentração de micotoxinas em cereais. Produtos contaminados com altos níveis de toxinas não podem ser utilizados na produção de alimentos nem serem consumidos.

A Comissão Européia estabeleceu um limite legal de $1250 \mu \mathrm{g} / \mathrm{kg}$ de cereais não transformados comercializados para a indústria alimentar, com uma exceção para o trigo duro, para o qual o limite legal é $1750 \mu \mathrm{g} / \mathrm{kg}$ (CE, 2007).

No Brasil, recentemente a ANVISA publicou uma Resolução ( $\left.\operatorname{RDC} n^{\circ} 7\right)$ que dispõe sobre os limites máximos toleráveis (LMT) de micotoxinas em alimentos. A legislação abrange limites máximos inclusive para os derivados do trigo como trigo integral, farinha de trigo e farelo de trigo, com aplicação imediata.

Os limites estabelecidos apresentados na Tabela 3 são para aplicação em 2014 e vão se tornar gradualmente mais rígidos, garantindo que o mercado brasileiro se adeque a legislação e proporcionando produtos de maior qualidade e controle micotoxicológico. O LMT para DON em trigo integral, trigo para quibe, farinha de trigo integral, farelo de trigo passará para $1000 \mu \mathrm{g} / \mathrm{kg}$ em 2016. Da mesma forma, o LMT para farinha de trigo, massas, crackers, biscoitos de água e sal e produtos de panificação será de $750 \mu \mathrm{g} / \mathrm{kg}$ em 2016. 
Tabela 3- Limites máximos de DON e ZEA em trigo e derivados no Brasil.

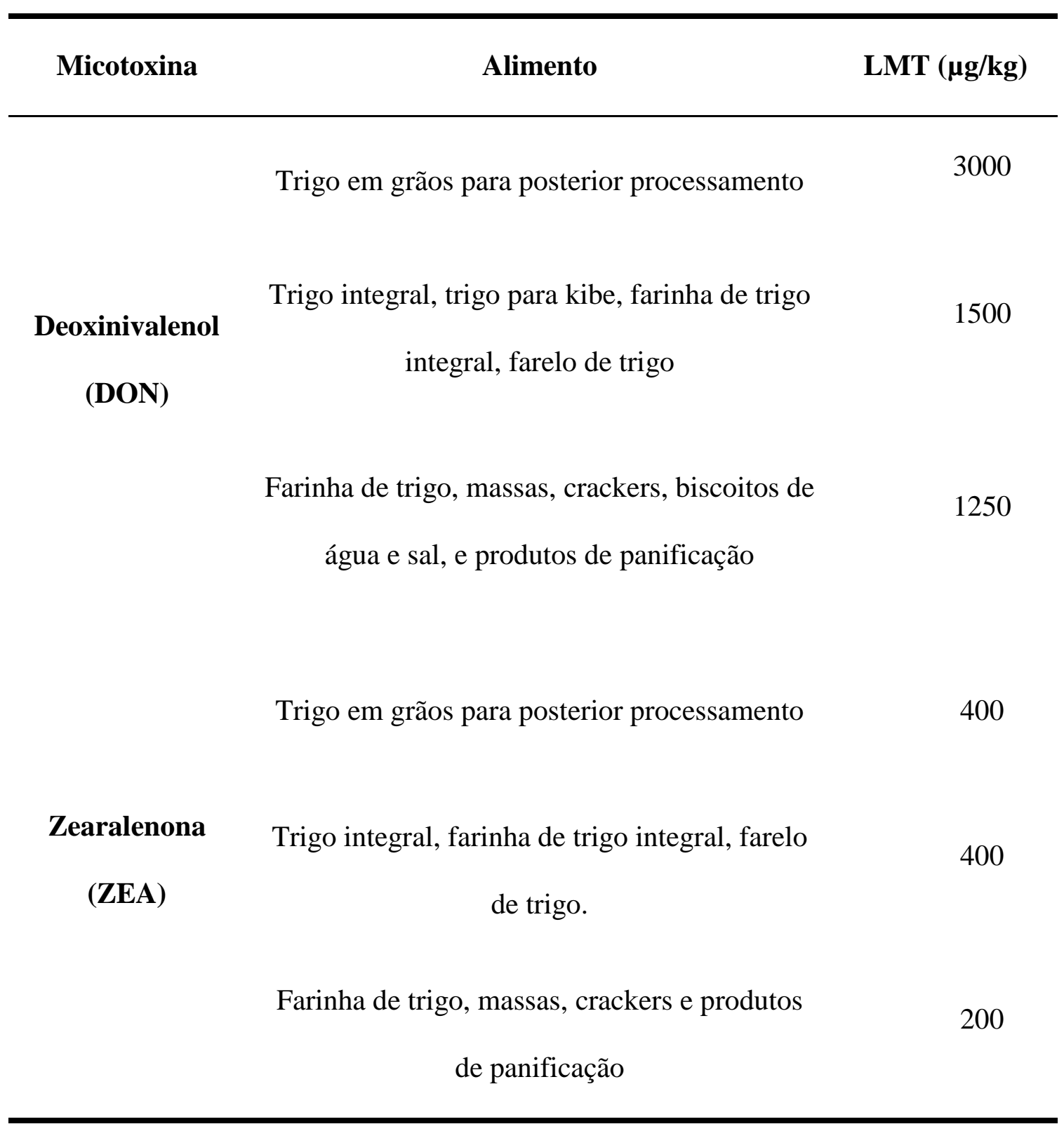

Fonte: ANVISA. RDC n 7, 2011.

Com relação a ZEA, em 2016, o LMT para farinha de trigo, massas, crackers e produtos de panificação será de $100 \mu \mathrm{g} / \mathrm{kg}$ e para trigo integral, farinha de trigo integral e farelo de trigo será de $200 \mu \mathrm{g} / \mathrm{kg}$.

Embora o risco potencial para a saúde do consumidor e a ocorrência em alimentos das micotoxinas de Alternaria tenham sido demonstrados, até o presente momento não existem regulamentos específicos para estas toxinas em nenhum tipo de alimento, em nenhum país. 
A falta de regulamentação é em parte devido à falta de informações sobre a ocorrência da toxina, o que é um pré-requisito para a mitigação eficaz. Devido à toxicidade desta toxina, é de grande importância estudos que demostrem a necessidade de incluí-la em legislações brasileiras e internacionais.

No entanto, as legislações apresentam valores máximos recomendados tendo em conta as micotoxinas como presença única nos alimentos, sem considerar a co-ocorrência, que podem levar a efeitos aditivos.

Os níveis máximos admitidos de micotoxinas em alimentos dependem muito da condição geográfica, económica e política, assim como, do nível de industrialização e características agronómicas de cada país. Os países sem produção própria de determinado alimento têm, geralmente, uma exigência mais elevada relativamente a países onde os produtos são produzidos (SANTOS, 2011).

O monitoramento de micotoxinas em alimentos, exigidos com mais rigidez recentemente no país, necessita da utilização de métodos confiáveis para a obtenção de informações sobre o consumo destas toxinas por parte dos consumidores.

Não é possível, pelo menos atualmente, impedir ou eliminar totalmente a proliferação de fungos, sendo a presença de micotoxinas em alimentos um perigo real. Para exercer controle sobre esse perigo, é necessário estabelecer limites tão baixos quanto possíveis, devendo ser aplicadas as melhores práticas e tecnologias na produção, manipulação, armazenamento, processamento e embalagem, de forma a evitar que um alimento contaminado seja comercializado ou consumido.

Assim, conhecer a extensão dessas contaminações, inclusive posteriormente à colheita, fornecerá informações importantes, escassas em nosso país, para os diversos segmentos envolvidos com a produção, utilização e comercialização de trigo bem como para fiscalização e pesquisa, sempre visando garantir ao consumidor final produtos de melhor qualidade. 


\section{PROPOSIÇÃO E OBJETIVOS}

A deterioração dos grãos de cereais por fungos toxigênicos constitui um assunto de grande importância, destacando a constante influência de fatores intrínsecos (atividade de água) e extrínsecos (temperatura, umidade relativa do ar, precipitação pluvial).

O trigo é considerado muito importante na economia da agricultura mundial e isso resulta cada vez mais no aumento da produção e na melhoria da qualidade das sementes. No entanto, os grãos estão constantemente sujeitos a ação de fungos durante todo seu processo de cultivo, desde o campo até os processos de armazenamento e transporte. Além disso, a produção de micotoxinas pelos fungos prejudicam a qualidade do produto acarretando assim, perdas econômicas e sérios prejuízos à saúde humana e animal.

Em 1988, o DON foi responsável por uma toxicose humana em larga escala, no Vale do Kashimir, na Índia. A toxicose foi reportada também na China, Japão e Korea, entre outros países (BEARDALL; MILLER, 1994; KUIPER-GOODMAN, 1994). Do ponto de vista econômico, o prejuízo causado pela contaminação de alimentos com micotoxinas são inestimáveis. Estudos realizados nos Estados Unidos apontam prejuízo anual de 637 milhoes de dólares, causado pela contaminação de alimentos com DON (CAST, 2003).

Em todo o mundo, estudos têm reportado a necessidade e urgência de mais investigações a respeito de micotoxinas em alimentos. Contudo, os trabalhos publicados ainda são incipientes e deixam a desejar quando se trata de analisar a problemática da frequência de contaminação fúngica e de seus metabólitos tóxicos, envolvendo o acompanhamento do produto durante o armazenamento.

Institutições e organizações do mundo todo vêm tentando integrar ações e estratégias que minimizem a ocorrência de micotoxinas e os efeitos danosos à saúde humana, mas passados mais de 20 anos, o problema ainda persiste.

Estes fatos, associados à carência de estudos no Brasil sobre o assunto e à necessidade dos órgãos governamentais conhecerem a problemática da contaminação do trigo por fungos e micotoxinas, motivaram esta pesquisa, que teve como objetivos:

1-) efetuar o monitoramento do trigo recém-colhido e armazenado, quanto à contaminação por fungos e por micotoxinas, especificamente deoxinivalenol, zearalenona e alternariol;

2-) Correlacionar os resultados obtidos com os níveis de atividade de água das amostras e com os fatores climatológicos das regiões. 


\section{MATERIAL E MÉTODOS}

\subsection{CARACTERIZAÇÃO DAS UNIDADES EXPERIMENTAIS}

Os experimentos foram conduzidos em duas localidades do Estado de São Paulo de maior importância no cultivo de trigo: Avaré (latitude $23^{\circ} 5^{\prime} 56^{\prime \prime}$ Sul, longitude $48^{\circ} 55^{\prime} 33^{\prime \prime}$ Oeste, e altitude de $766 \mathrm{~m}$ ), de clima tropical de altitude e latossolo vermelho amarelo fase arenosa; e Capão Bonito (latitude 2400'21" Sul, longitude 48²0'58" Oeste, e altitude de $705 \mathrm{~m}$ ), região localizada na zona fisiográfica do Paranapiacaba, de clima temperado e Latossolo vermelho escuro distrófico (Figura 12).

Figura 92 - Mapa do Estado de São Paulo, identificando os municípios onde foram realizados os experimentos.

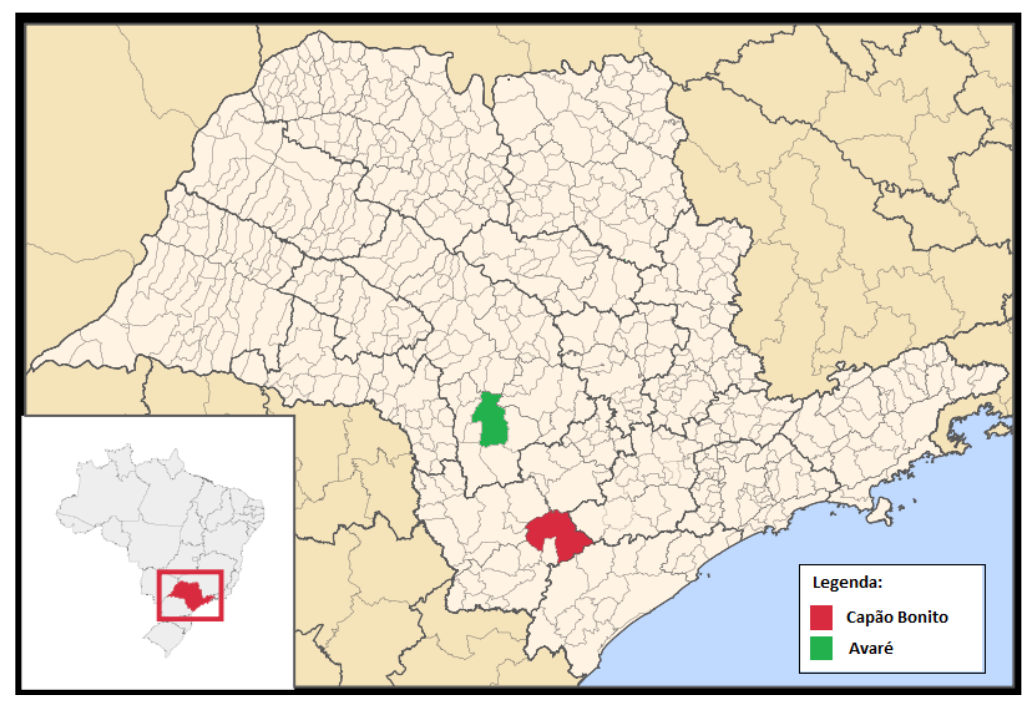

Fonte: Modificado de wikipedia.org

\subsection{AMOSTRAGEM}

O cultivar utilizado foi o IAC-381 (KUARA), lançado em 2008, caracterizado pelo bom potencial de rendimento de grãos nas condições de cultivo de sequeiro e irrigação por aspersão. 
Figura 103 - Imagem do cultivar IAC-381.

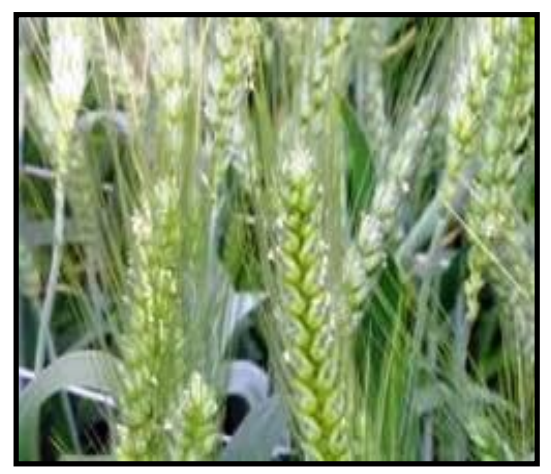

Fonte: Instituto Agronômico de Campinas

\subsubsection{Amostragem de Grãos do Trigo}

Para a amostragem dos grãos de trigo recém-colhido, foram coletadas 10 amostras de cada região de plantio, em pontos diferentes, escolhidos ao acaso. Não foi observado qualquer sintoma de infecções fitopatogênicas nos grãos em nenhuma das coletas.

O armazenamento foi realizado na mesma região do cultivo em "bags" contendo 1 tonelada de grãos, totalizando 6 'bags' por região. Mensalmente, durante 6 meses de armazenamento, foram colhidas 10 amostras, em pontos diversos de cada 'bag', até completar uma amostra de $1 \mathrm{~kg}$ (FONSECA, 1991). As amostras recém-colhidas (10 de cada região) juntamente com as amostras armazenadas (60 de cada região) totalizaram 140 amostras.

Figura 114 - "Bags" onde foram armazenados os grãos de trigo.
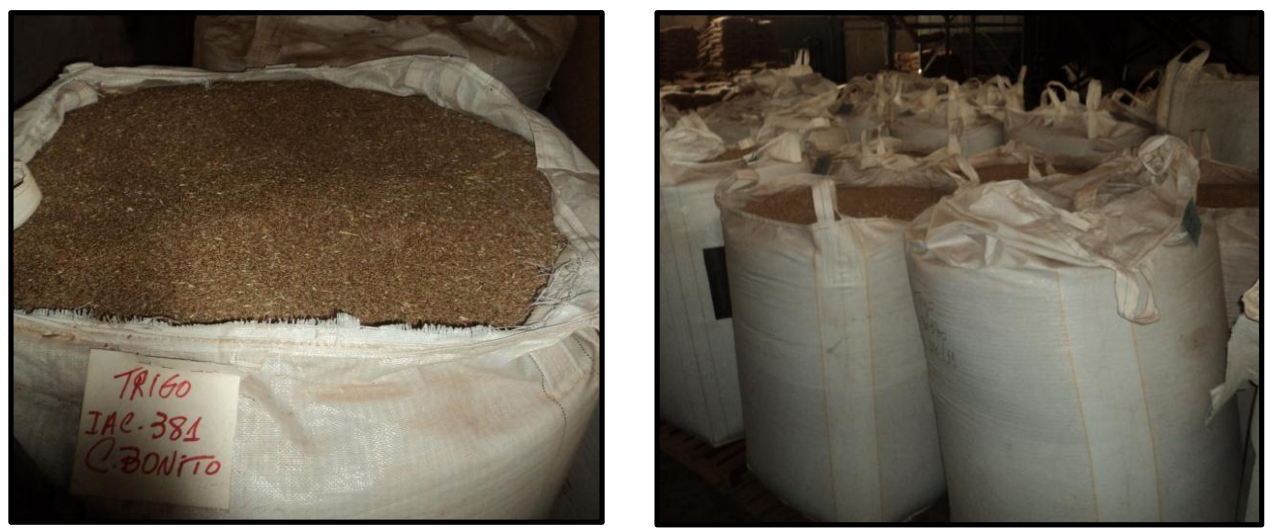
As amostras de Capão Bonito foram colhidas em Agosto de 2011 e armazenadas até Fevereiro de 2012. Os grãos foram beneficiados na quarta coleta (Novembro de 2011). As amostras de Avaré foram colhidas em Setembro de 2011 e armazenadas até Março de 2012 e estavam beneficiadas desde a primeira coleta.

\subsection{AVALIAÇÕES LABORATORIAIS}

\subsubsection{Determinação de Atividade de Água (Aa)}

As atividades de água das amostras de trigo foram determinadas por meio do aparelho AQUALAB CX-2 (Decagon Devices Inc.).

\subsubsection{Técnica da Semeadura Direta para o Isolamento da Micobiota Fúngica dos Grãos de Trigo (BERJAK, 1984)}

De cada uma das sub-amostras $(1 \mathrm{~kg})$ de grãos de trigo, previamente homogeneizadas, foram retiradas aproximadamente $60 \mathrm{~g}$ para desinfecção em solução de hipoclorito de sódio $0,4 \%$ por 3 minutos, seguida de lavagens vigorosas com água destilada esterilizada para eliminação dos contaminantes externos. Após a desinfecção, 66 grãos foram selecionados ao acaso e semeados diretamente em 6 placas de Petri, 3 contendo ágar DRBC (Ágar Dicloran Rosa Bengala Cloranfenicol - OXOID) e 3 placas de Petri contendo ágar DG 18 (Ágar Dicloran Glicerol - OXOID). Cada placa contendo 11 grãos foi incubada a $25^{\circ} \mathrm{C}$ por 5 dias e os resultados expressos em porcentagem do total de grãos semeados.

As colônias de diferentes tipos morfológicos foram isoladas em Ágar Batata (PDA) e submetidas à identificação através da técnica de microcultivo (RIDELL, 1950). Os fungos foram classificados em nível de gênero, entretanto, aqueles pertencentes ao gênero Fusarium e Alternaria foram classificados até espécie, de acordo com os seguintes compêndios: LESLIE; SUMMERELL, 2006; NELSON; TOUSON; MARASAS, 1983; NELSON, 1992; O’DONNELL et al., 2004; PITT; HOCKING, 2009. 
Figura 125 - Semeadura direta para o isolamento da micobiota fúngica nos grãos de trigo em meio DRBC (acima) e em meio DG 18 (abaixo).
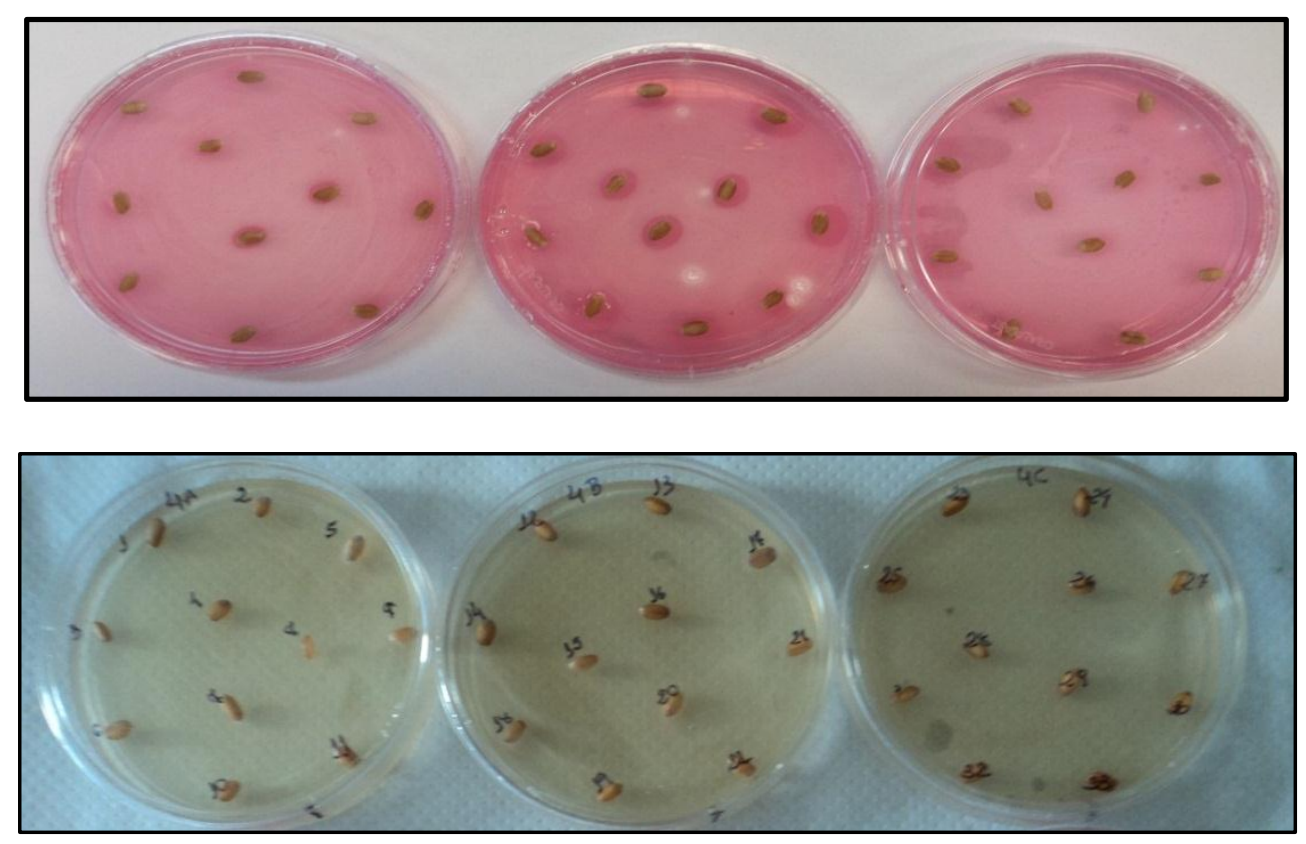

\subsubsection{Identificação dos Isolados de Fusarium spp. e Alternaria spp.}

A identificação morfológica dos isolados de Fusarium spp. foi confirmada através do sequenciamento parcial do gene do fator de elongação 1- $\alpha$, utilizando os primers forward e reverse, ef-1/ef-2 ( 650 pb), como descrito por GEISER et al., 2004.

Os isolados de Alternaria spp. foram identificados através do sequenciamento parcial do gene Alt a 1, concebido com base nas regiões conservadas de A. alternata e A. brassicicola (HONG et al., 2005), utilizando os primers forward e reverse, Alt-for/Alt-rev, (534 bp).

\subsubsection{Obtenção de Massa Fúngica e Extração de DNA}

Para a obtenção da biomassa fúngica, as cepas foram semeadas em placa de Petri contendo ágar YES (Yeast Extract Sucrose) e incubadas por três dias a $25^{\circ} \mathrm{C}$ e o DNA genômico foi extraído conforme o manual de instruções do kit Easy-DNA ® (Invitrogen).

O micélio obtido foi macerado em gral e pistilo previamente esterilizados e transferido para microtubo de $1,5 \mathrm{~mL}$. Foram adicionados $350 \mu \mathrm{L}$ da solução A, as amostras foram então homogeneizadas em vortex e o conteúdo incubado a $65{ }^{\circ} \mathrm{C}$ por 15 minutos. Foram 
adicionados $150 \mu \mathrm{L}$ da solução B e as amostras novamente homogeneizadas. Em seguida, 500 $\mu \mathrm{L}$ de clorofórmio foram adicionados e homogeneizou-se em vortex. As amostras foram centrifugadas a $1400 \mathrm{rpm}$ por 20 minutos e, posteriormente, a fase superior foi transferida para um novo microtubo de $1,5 \mathrm{~mL}$. Às amostras, foi adicionado $1 \mathrm{~mL}$ de etanol absoluto (-20 $\left.{ }^{\circ} \mathrm{C}\right)$ e estas foram armazenadas em freezer $\left(-20{ }^{\circ} \mathrm{C}\right)$ por 1 hora. Após esse período, as amostras foram submetidas à centrifugação (1400 rpm/15 minutos) e os microtubos foram vertidos para remoção do etanol. Foram feitas duas lavagens com $500 \mu \mathrm{L}$ de etanol $80 \%$ (-20 $\left.{ }^{\circ} \mathrm{C}\right)$. Após mais uma centrifugação, o excesso de etanol é removido das amostras e em seguida são mantidas 5 minutos à temperatura ambiente.

O resíduo de DNA das amostras foi ressuspendido em $100 \mu \mathrm{L}$ de tampão de eluição (TE) e $2 \mu \mathrm{L}$ de RNAse $(2 \mathrm{mg} / \mathrm{mL})$, e incubado a $37{ }^{\circ} \mathrm{C}$ por 30 minutos. O DNA total obtido foi mantido a $-20^{\circ} \mathrm{C}$ até a utilização.

\subsubsection{Quantificação do DNA de Fusarium spp. e Alternaria spp.}

O DNA total extraído foi quantificado em NanoDrop 2000 C (Thermo Scientific) em comprimento de onda de $260 \mathrm{~nm}$ e em $280 \mathrm{~nm}$ para verificar a pureza do DNA através da razão entre as absorbâncias (DO260/DO280) que deverá estar entre 1,8 e 2,0. Valores abaixo de 1,8 indicam grande quantidade de contaminantes e proteínas. A concentração foi dada em $\mathrm{ng} / \mu \mathrm{L}$. As amostras que apresentaram elevadas concentrações de DNA foram diluídas com água Milli Q a fim de se obter valores entre 30 e $50 \mathrm{ng} / \mu \mathrm{L}$ de DNA.

\subsubsection{Amplificação do fragmento parcial do gene TEF-1 $\alpha$}

O protocolo padrão de PCR foi usado para amplificar o fragmento de aproximadamente $650 \mathrm{pb}$ da região entre os nucleotídeos 75 a 978 do gene TEF-1 $\alpha$. O DNA foi amplificado em termociclador Applied Biosystems Thermocycler GeneAmp ${ }^{R}$ 9700, utilizando na reação os iniciadores forward e reverse, , EF-1 (forward primer; 5'ATGGGTAAGGA(A/G)GACAAGAC-3') e EF-2 (reverse primer; 5'GGA(G/A)GTACCAGT(G/C)ATCATGTT-3’) (O`DONNELL et al., 1998; GEISER et al., 2004). O volume total da reação foi de $25 \mu \mathrm{L}$, utilizando-se buffer $3,0 \mu \mathrm{L}, 2,0 \mu \mathrm{L}$ a $50 \mathrm{mM}$ de $\mathrm{MgCl}_{2}, 0,8 \mu \mathrm{L}$ dNTP a $25 \mathrm{mM}, 1,8 \mu \mathrm{L}$ de cada iniciador a $10 \mu \mathrm{M}, 0,5 \mu \mathrm{L}$ de Taq DNA polimerase a $0,04 \mathrm{U} / \mu \mathrm{L}$ e $4 \mu \mathrm{L}$ do DNA diluído. Os parâmetros da amplificação foram: $94{ }^{\circ} \mathrm{C}$ 
a 5 minutos para a desnaturação inicial, 35 ciclos a $94{ }^{\circ} \mathrm{C}$ ( 1 minuto), $57{ }^{\circ} \mathrm{C}$ (1 minuto), $72{ }^{\circ} \mathrm{C}$ (30 segundos) e um ciclo adicional de $72{ }^{\circ} \mathrm{C}$ por 7 minutos (extensão final).

3.3.3.4 Amplificação do fragmento parcial do gene Alt a 1

O DNA foi amplificado em termociclador Applied Biosystems Thermocycler GeneAmp $^{R}$ 9700, utilizando na reação os iniciadores forward e reverse, , Alt-for (5'ATGCAGTTCACCACCATC-3') e Alt-rev (5'-ACGAGGGTGAYGTAGGCG-3') (HONG et al., 2005). O volume total da reação foi de $25 \mu \mathrm{L}$, utilizando-se buffer $3,0 \mu \mathrm{L}, 2,0 \mu \mathrm{L}$ a 50 $\mathrm{mM}$ de $\mathrm{MgCl}_{2}, 0,8 \mu \mathrm{L}$ dNTP a $25 \mathrm{mM}, 1,5 \mu \mathrm{L}$ de cada iniciador a $10 \mu \mathrm{M}, 0,5 \mu \mathrm{L}$ de Taq DNA polimerase a $0,04 \mathrm{U} / \mu \mathrm{L}$ e $4 \mu \mathrm{L}$ do DNA diluído. Os parâmetros da amplificação foram: $94{ }^{\circ} \mathrm{C}$ a 5 minutos para a desnaturação inicial, 35 ciclos a $94{ }^{\circ} \mathrm{C}$ (30 segundos), $62{ }^{\circ} \mathrm{C}(30$ segundos), $72{ }^{\circ} \mathrm{C}$ (1 minuto) e um ciclo adicional de $72{ }^{\circ} \mathrm{C}$ por 10 minutos (extensão final).

\subsubsection{Eletroforese}

Os produtos das reações foram visualizados por eletroforese em gel de agarose $(1,2 \%)$ com TBE 0,5x e corados com safe DNA (Invitrogen). O marcador de peso molecular utilizado foi de $1000 \mathrm{~Pb}$ DNA ladder (Invitrogen). A presença das bandas foi visualizada pela exposição dos géis à luz UV e fotografados por fotodocumentador Doc Print Vilber Lourmat Biosystems.

\subsubsection{Purificação do DNA}

O fragmento gerado foi purificado utilizando o kit para purificação ExoSAP-IT ( $G E$ Healthcare). $5 \mu \mathrm{L}$ do fragmento de DNA (20 a $40 \mathrm{ng}$ ) e $2 \mu \mathrm{L}$ de ExoSAP-IT foram adicionados a um microtubo de $0,2 \mathrm{~mL}$ e colocados em termociclador Applied Biosystems Thermocycler GeneAmpR $9700 \mathrm{com}$ as seguintes condições: $37{ }^{\circ} \mathrm{C}$ por 15 minutos e $80{ }^{\circ} \mathrm{C}$ por 15 minutos.

\subsubsection{Reação de Sequenciamento do Produto de PCR}

As reações de sequenciamento foram realizadas em termociclador Applied Biosystems Thermocycler GeneAmp PCR System 9700, utilizando $2 \mu \mathrm{L}$ do BigDye Terminator v3.3. 
(Applied Biosystems), $2 \mu \mathrm{L}$ do tampão para BigDye, $1 \mu \mathrm{L}$ do iniciador $(4 \mu \mathrm{M}), 4 \mu \mathrm{L}$ de água Milli Q esterilizada e $1 \mu \mathrm{L}$ do DNA da amostra (10 a $20 \mathrm{ng}$ ). As condições das reações foram: $95{ }^{\circ} \mathrm{C}$ por 2 minutos, seguido de 35 ciclos de $96{ }^{\circ} \mathrm{C}$ por 20 segundos, $55^{\circ} \mathrm{C}$ por 30 segundos e $60{ }^{\circ} \mathrm{C}$ por 4 minutos.

\subsubsection{Precipitação do DNA}

Às reações, foram adicionados $40 \mu \mathrm{L}$ de solução álcool isopropílico PA 60\%. As amostras foram agitadas e mantidas à temperatura ambiente, protegidas da luz, por 15 minutos. Após centrifugação a 3000 rpm por 30 minutos, o sobrenadante foi descartado e 150 $\mu \mathrm{L}$ de etanol $65 \%$ foram adicionados. O material foi novamente centrifugado por 10 minutos a $3000 \mathrm{rpm}$ e o sobrenadante foi descartado. Este último passo foi repetido mais uma vez e, em seguida, o tubo foi seco em Concentrator (Eppendorf) durante 30 minutos.

As amostras foram ressuspendidas em $10 \mu \mathrm{L}$ de formamida Hi-Di (Applied Biosystems), desnaturadas a $95{ }^{\circ} \mathrm{C}$ por 2 minutos e incubadas em gelo por 1 minuto. Em seguida, foram aplicadas às colunas capilares contendo o polímero POP6 no sequenciador automático Abi Prism ${ }^{R}$ Genetic Analyser (Applied Biosystems).

3.3.3.9 Análise das Sequências do Gene TEF-1 $\alpha$ das Amostras de Fusarium spp. e do gene Alt a 1 das amostras de Alternaria sp.

As sequências dos genes TEF-1 $\alpha$ dos isolados de Fusarium spp., assim como as sequências dos genes Alt a 1 dos isolados de Alternaria spp., foram editadas utilizando-se o software BioEdit v7.0.9.0 e posteriormente alinhadas com o Blast dos bancos de dados do GeneBank (NATIONAL CENTER FOR BIOTECHNOLOGY INFORMATION).

\subsubsection{Determinação de Micotoxinas nas Amostras de Trigo}

A água utilizada no preparo das soluções foi purificada através do sistema Milli- $Q$ Gradient A10 da Millipore (EUA).

Os padrões de DON, ZEA e AOH, utilizados foram todos provenientes da SigmaAldrich (Alemanha). A partir dos padrões liofilizados foram preparadas três soluções estoque, as quais foram utilizadas na preparação dos padrões intermediários para o preparo da curva de calibração e fortificação de amostras. As soluções estoque de $\mathrm{AOH}$ foram preparadas em 
metanol, enquanto as soluções estoque de DON e ZEA foram preparadas em acetonitrila, todas com concentração de com concentração de $100 \mu \mathrm{g} / \mathrm{mL}$.

\subsubsection{Extração das micotoxinas das amostras de trigo}

Foram transferidos para um tubo falcon, $3 \mathrm{~g}$ de cada amostra previamente triturada $\mathrm{e}$ homogeneizada, e adicionados $24 \mathrm{~mL}$ de metanol - água (70:30, v/v). Após agitação por 20 minutos em agitador mecânico horizontal, as amostras foram centrifugadas a $3000 \mathrm{rpm}$ por 5 minutos e o sobrenadante filtrado em papel de filtro (Whatman $\mathrm{n}^{\mathrm{o}} 4,12 \mathrm{~cm}$ ). Foram pipetados $40 \mu \mathrm{L}$ do filtrado em vials e o resíduo foi evaporado até secura com ar comprimido e mantido à $-20{ }^{\circ} \mathrm{C}$ até a análise cromatográfica.

\subsubsection{Cromatografia Líquida de Alta Eficiência acoplada à Espectrometria de Massas Sequencial (CLAE-MS/MS)}

O resíduo foi ressuspendido em $1000 \mu \mathrm{L}$ de eluente da fase móvel, solução A (água : acetato de amônio (995:5, v/v )) : solução B (água:metanol:acetato de amônio (95:900:5, $\mathrm{v} / \mathrm{v} / \mathrm{v})),(1: 1 \mathrm{v} / \mathrm{v})$. A solução foi agitada por 30 segundos e $20 \mu \mathrm{L}$ foram injetados no cromatógrafo líquido (Agilent Technologies, Série 1200, EUA), que consiste em uma bomba binária, um degaseificador, um forno de coluna, e um amostrador automático. A análise foi feita com coluna de fase reversa Eclipse XDB - C8 (150 x 4,6 mm, Agilent Technologies) e a temperatura da coluna foi mantida a $25{ }^{\circ} \mathrm{C}$. Os analitos foram ionizados por uma fonte electrospray em modo positivo e detectadas em espectrômetro de massas triploquadrupolo (Applied Biosystems modelo API 5500 Q Trap).

O espectrômetro de massas foi apropriadamente ajustado e calibrado utilizando uma solução padrão de calibração com massas conhecidas. Com o desempenho do instrumento maximizado, os parâmetros encontrados foram utilizados por todos os experimentos realizados no instrumento.

Primeiramente, infundiu-se uma solução padrão de cada uma das micotoxinas separadamente para encontrar os espectros referentes a cada um dos compostos, através de experimentos de varredura em modo MS. Os experimentos de varredura foram realizados a partir da ionização por electrospray (ESI).

Após definidos a fonte e o modo de ionização, os parâmetros de massas referentes ao analito (declustering potential (DP), collision energy (CE), collision cell exit potential (CXP) 
e entrance potential (EP)) foram otimizados também pela infusão de soluções padrão de cada micotoxina diretamente no espectrômetro de massas.

A partir de um experimento product ion foram selecionados os possíveis íons produtos da fragmentação da molécula de cada toxina. Para confirmar a origem destes íons foi realizado um experimento precursor íon, onde o instrumento busca possíveis precursores a partir da informação de produtos gerados. Os íons precursor de cada micotoxina e os íons produto gerados pela fragmentação da massa molecular inicial estão apresentados na Tabela 3. A escolha dos íons a serem monitorados para quantificação e qualificação foi feita através de experimentos de varredura em modo MS/MS.

Os parâmetros dependentes da fonte de ionização (collision gas (CAD), curtain gas (CUR), ion source gas 1 (GS1), ion source gas 2 (GS2), temperature (TEM) e ion spray voltage (IS)) foram otimizados através de análise por injeção em fluxo (FIA), utilizando soluções padrão de AOH, DON, ZEA e padrões internos (PI) (deepoxy-DON (DOM-1) e zearalanol (ZLANOL), a partir da otimização automática realizada pelo software, na qual diversas combinações de valores dos parâmetros foram testadas, a fim de definir a melhor combinação para a detecção dos analitos.

Após otimização dos parâmetros realizada de modo automático pelo instrumento, cada parâmetro foi verificado de maneira manual através da programação do instrumento para este fim. Para cada parâmetro foi criada um rampa com valores crescentes, sendo escolhido o valor que apresentasse a maior intensidade para o íon precursor. Os valores otimizados dos parâmetros composto-dependentes e fonte dependentes estão representados na Tabela 4.

Para a obtenção de cromatogramas bem definidos, com melhor relação sinal/ruído, em um curto intervalo de tempo, optou-se por usar diferentes proporções de fase móvel. Assim, a cromatografia foi iniciada com maior proporção de solvente aquoso, para eluição das micotoxinas mais polares, com aumento gradual de solvente orgânico, para posterior eluição das micotoxinas mais apolares. As micotoxinas são substâncias com uma ampla faixa de polaridade, portanto, uma fase móvel com grau variável de hidrofobicidade é necessária, principalmente quando se quer detectar mais de um analito na mesma corrida.

A fase móvel utilizada em gradiente era composta por uma solução aquosa de água:acetato de amônio (fase móvel A) e uma solução orgânica de metanol:água:acetato de amônio (fase móvel B), conforme mostrado na Tabela 5. 
Tabela 4 - Íons precursores, íons produtos e parâmetros fonte-dependentes e composto-dependentes otimizados.

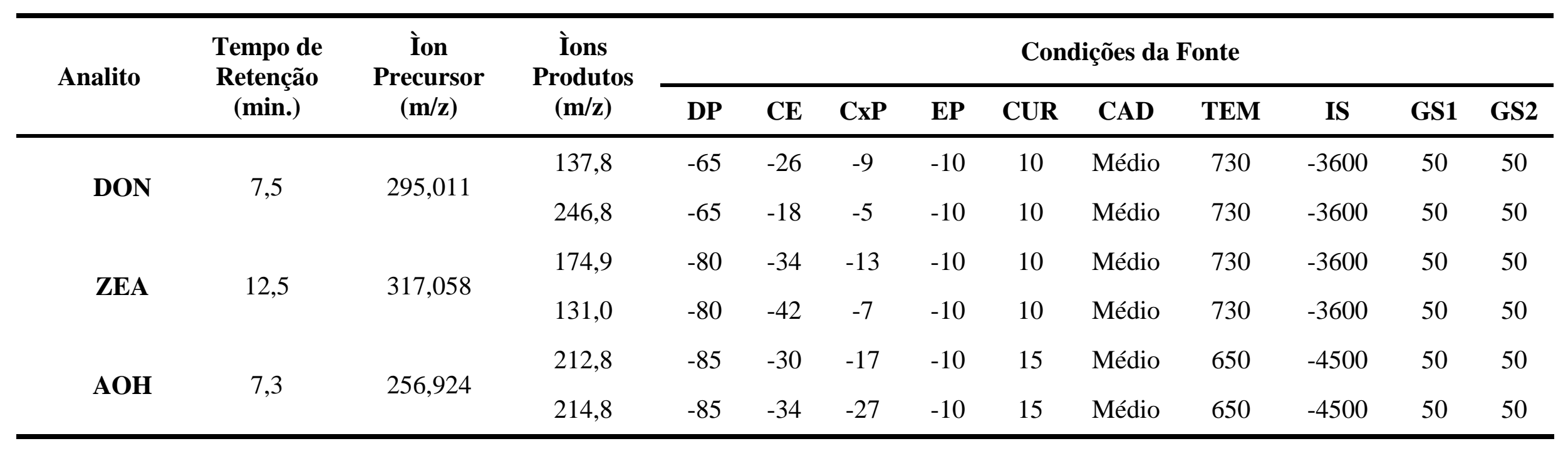

DP (declustering potential): potencial de desaglomeramento $(\mathrm{kV})$

$\mathrm{CE}$ (collision energy): energia de colisão $(\mathrm{eV})$

CXP (collision cell exit potential): potencial de saída na cela de colisão $(\mathrm{kV})$

EP (enhance potential): potencial de entrada $(\mathrm{kV})$

CAD (collision gas): gás de colisão (psi)

CUR (curtain gas): cortina de gás (psi)

GS1 (ion source gas 1): gás 1da fonte de íons (psi)

GS2 (ion source gas 1): gás 2 da fonte de íons (psi)

IS (ion spray voltage): voltagem no vaporizador (V)

TEM (temperature): temperatura do gás na fonte $\left({ }^{\circ} \mathrm{C}\right)$ 
Tabela 5 - Parâmetros da eluição por gradiente.

\begin{tabular}{|c|c|c|c|c|c|}
\hline \multicolumn{3}{|c|}{ DON e ZEA } & \multicolumn{3}{|c|}{$\mathrm{AOH}$} \\
\hline $\begin{array}{c}\text { Tempo } \\
\text { (min.) }\end{array}$ & $\begin{array}{c}\text { Solvente A } \\
(\%)\end{array}$ & $\begin{array}{c}\text { Solvente B } \\
(\%)\end{array}$ & $\begin{array}{c}\text { Tempo } \\
\text { (min.) }\end{array}$ & $\begin{array}{c}\text { Solvente A } \\
(\%)\end{array}$ & $\begin{array}{c}\text { Solvente B } \\
(\%)\end{array}$ \\
\hline 0,00 & 90 & 10 & 0,00 & 60 & 40 \\
\hline 1,01 & 90 & 10 & 2,00 & 60 & 40 \\
\hline 2,00 & 50 & 50 & 3,00 & 50 & 50 \\
\hline 7,00 & 10 & 90 & 5,50 & 0 & 100 \\
\hline 8,00 & 20 & 80 & 8,00 & 0 & 100 \\
\hline 8,01 & 0 & 100 & 8,01 & 60 & 40 \\
\hline 13,00 & 0 & 100 & 10,00 & 60 & 40 \\
\hline 13,01 & 90 & 10 & - & - & - \\
\hline 17,00 & 90 & 10 & - & - & - \\
\hline 23,00 & 90 & 10 & - & - & - \\
\hline
\end{tabular}

O gradiente de eluição da fase móvel mais eficiente para a separação de DON e ZEA foi realizado com vazão de $500 \mu \mathrm{L} \mathrm{min}^{-1}$. No primeiro minuto, a fase móvel era composta por $90 \%$ de fase aquosa e $10 \%$ de fase orgânica. A partir de 1,01 minutos, a composição foi mudando gradualmente, até que as porcentagens de fases aquosa e orgânica se igualassem em $50 \%$ em 2 minutos. De 2 a 7 minutos, a porcentagem de fase orgânica foi aumentando até $90 \%$. Entre 7 e 8 minutos a fase orgânica diminui em $10 \%$ até $80 \%$, intervalo de tempo em que o DON é detectado. A partir de 8,01 minutos, a porcentagem de fase orgânica alcança os $100 \%$, a qual se manteve durante 5 minutos. É nesse intervalo de tempo em que a ZEA é detectada. Aos 13,01 minutos, a composição da fase móvel voltou às condições iniciais de equilíbrio. O tempo total da análise cromatográfica foi de 23 minutos (Tabela 5).

A análise de $\mathrm{AOH}$ foi feita em corrida separada de DON e ZEA, mas o método estabelecido para detecção desta toxina também utilizou eluição por gradiente. O gradiente de eluição da fase móvel mais eficiente para a separação do $\mathrm{AOH}$ foi realizado com vazão de $1000 \mu \mathrm{L} / \mathrm{min}$. Nos primeiros 2 minutos, a fase móvel era composta por $60 \%$ de fase aquosa e $40 \%$ de fase orgânica. A partir de 2 minutos, a composição foi mudando gradualmente, até que as porcentagens de fases aquosa e orgânica se igualassem em 50\% em 3 minutos. De 3 a 5,5 minutos, a porcentagem de fase orgânica foi aumentando até $100 \%$, a qual se manteve 
durante 2,5 minutos, quando a composição da fase móvel voltou às condições iniciais de equilíbrio. O tempo total da análise cromatográfica foi de 10 minutos (Tabela 5).

\subsubsection{Preparo da curva analítica}

Para a maioria das técnicas cromatográficas, observa-se uma relação linear entre a resposta instrumental medida (eixo y, variável dependente) e a concentração do analito (eixo $\mathrm{x}$, variável independente). Essa relação produz uma equação de regressão linear $\mathrm{y}=\mathrm{ax}+\mathrm{b}$, que relaciona as duas variáveis x e y e gera os coeficientes de regressão a (inclinação da curva) e b (intersecção da curva analítica com o eixo y, quando $x=0$ ) (RIBANI et al., 2004).

As curvas analíticas foram preparadas diariamente através da diluição de volumes adequados de uma solução intermediária. Foram injetados diferentes concentrações de padrão para DON: 1, 2, 3, 5, 10, 20 e 40 ppb; ZEA: 0,1, 0,5, 1, 2, 4, 5 e 10 ppb; e AOH: 6, 10, 20, 30, 40 e $80 \mathrm{ppb}$.

As micotoxinas DON e ZEA foram quantificadas utilizando-se o método de padronização externa. As curvas analíticas foram obtidas injetando um nível subsequente ao outro, em ordem crescente do nível de concentração, obtendo-se as áreas e o tempo de retenção de cada toxina. Plotando-se os valores de concentração no eixo das abscissas (x) e os valores das áreas no eixo das ordenadas (y) foram construídas as curvas analíticas e obtidos a equação da reta e o coeficiente de determinação $\left(\mathrm{r}^{2}\right)$.

\subsubsection{Recuperação e Precisão}

O teste de recuperação é um dos processos mais utilizados para avaliação da exatidão do método. A recuperação (ou fator de recuperação), R, é definida como a proporção da quantidade de analito, presente ou adicionada na porção analítica do material teste, que é extraída e passível de ser quantificada (THOMPSON; ELLISON; WOOD 2002). A recuperação é calculada pela Equação 2:

$$
\mathbf{R}(\%)=(\text { concentração medida/concentração adicionada }) \times 100
$$


Tabela 6 - Níveis de fortificação utilizados no teste de recuperação para cada toxina.

\begin{tabular}{c|c}
\hline Analito & Nível de Fortificação $(\boldsymbol{\mu g} / \mathbf{k g})$ \\
\hline \multirow{2}{*}{ DON } & 200 \\
& 500 \\
& 1000 \\
ZEA & 20 \\
& 200 \\
& 600 \\
AOH & 10 \\
& 300 \\
\hline
\end{tabular}

Foram escolhidos três níveis de concentração para realização das fortificações de cada uma das toxinas e estes estão apresentados na Tabela 6. Como não há legislação específica para $\mathrm{AOH}$, os níveis foram escolhidos baseados nas concentrações médias encontradas em trabalhos publicados (AZCARATE et al., 2008; MÜLLER; KORN, 2013; SCOTT et al., 2012). Os níveis de fortificação com DON e ZEA foram definidos baseados no limite de quantificação do método, um valor intermediário e um valor alto de concentração, também seguindo trabalhos científicos (JUODEIKIENE et al., 2011; MONBALIU et al., 2010; SOLEIMANY; JINAP; ABAS, 2012).

A precisão representa a dispersão de resultados entre ensaios independentes, repetidos de uma mesma amostra, amostras semelhantes ou padrões sob condições definidas. É expressa através da estimativa do desvio padrão relativo (DPR), calculado pela Equação 3 (INMETRO, 2003):

$$
\operatorname{DPR}(\%)=(\mathrm{s} / \mathbf{x}) * 100
$$

em que s é o desvio padrão e x é a concentração média determinada. 
3.3.4.5 Limite de detecção e limite de quantificação

Para determinar o limite de detecção e o limite de quantificação foi utilizado o método da relação sinal-ruído. Para isso foram empregadas soluções analíticas preparadas no diluente a partir da solução intermediária e extratos das amostras fortificadas.

$\mathrm{Na}$ determinação do limite de detecção do instrumento foram realizadas sucessivas diluições de padrões de cada toxina em diluente e estas foram injetadas no sistema até que se obtivesse uma relação 3:1 entre o pico do analito e o ruído da linha base nas proximidades do tempo de retenção do pico de cada toxina. Para o limite de quantificação fez-se o mesmo até que se obtivesse uma relação de 10:1.

O limite de detecção e limite de quantificação do método foram determinados após uma amostra fortificada ser submetida ao procedimento de extração proposto e os extratos serem injetados até que se obtivesse a mesma relação descrita para os limites instrumentais.

\subsection{ANÁLISE DOS FATORES CLIMATOLÓGICOS DAS REGIÕES}

Durante o período de armazenamento, os dados climatológicos referentes à temperatura $\left({ }^{\circ} \mathrm{C}\right)$, precipitação pluvial $(\mathrm{mm})$ foram registrados na região do experimento.

\subsection{ANÁLISE ESTATÍSTICA}

As análises estatísticas deste trabalho foram feitas utilizando-se os softwares $\mathrm{R} 2.9$ pacote Gamlss e SAS 9.1, utilizando análises de variância (ANOVA) e modelos de regressão linear para determinar a influência do tempo de armazenamento na freqüência de isolamento de Fusarium spp.e Alternaria spp.. O teste de regressão também foi utilizado para selecionar as variáveis explicativas (fatores abióticos) mais representativas sobre as variáveis respostas (frequiência de isolamento fúngico e produção de micotoxinas) (NETER et al., 1996). 


\section{DELINEAMENTO EXPERIMENTAL}

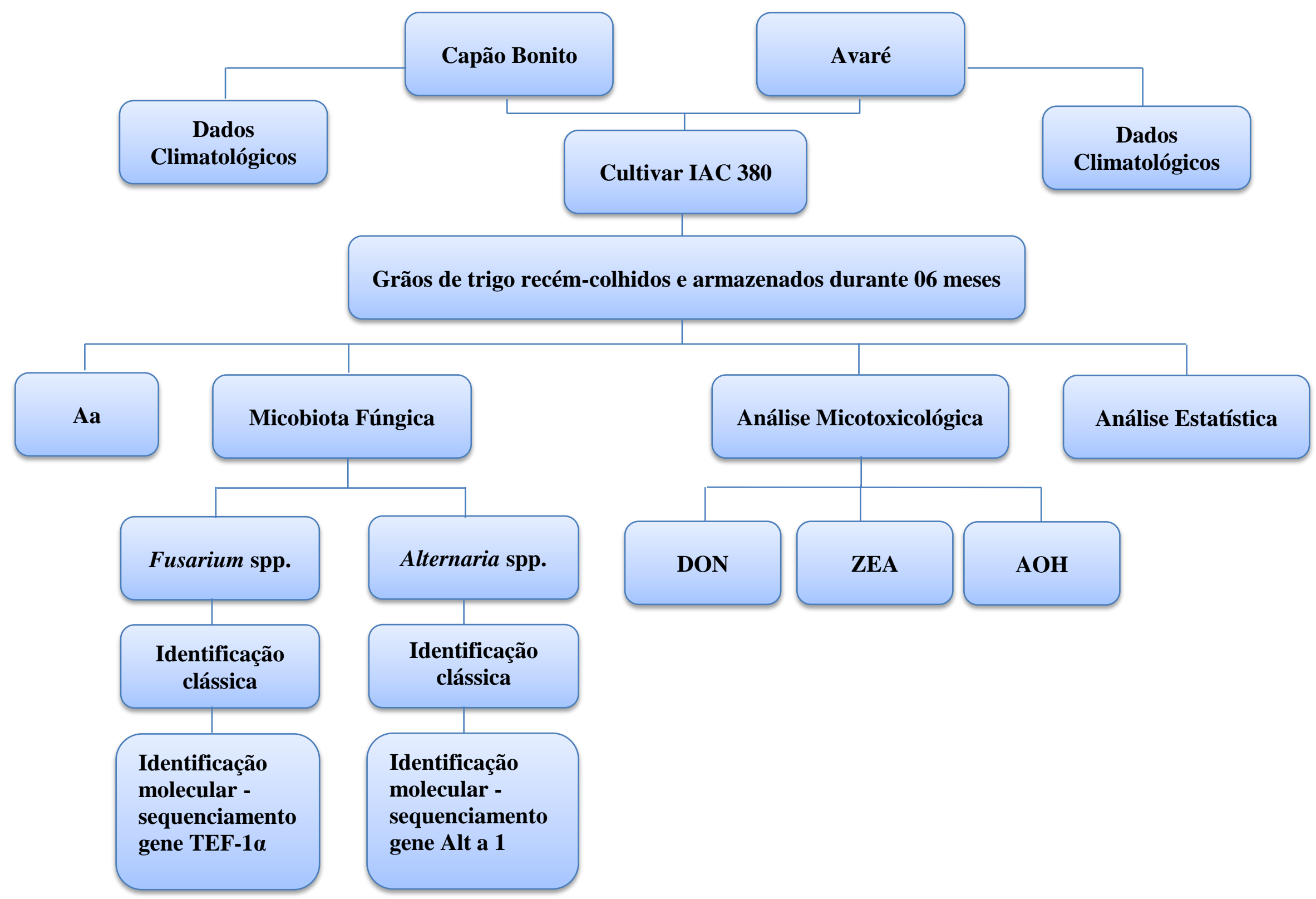




\section{RESULTADOS E DISCUSSÃO}

A contaminação fúngica e a consequente produção de micotoxinas representam um problema econômico a nível mundial devido à sua elevada incidência em alimentos para animais e humanos e à dificuldade no seu controle e eliminação.

\subsection{MICOBIOTA}

A escolha do meio de cultura é uma etapa importante no processo de isolamento e identificação de fungos em alimentos. Assim sendo, em nossa pesquisa, o isolamento da micobiota foi realizado utilizando dois meios de cultura: DRBC, indicado para o isolamento de fungos em alimentos com alta atividade de água, e DG 18, indicado para alimentos com baixa umidade. (PITT; HOCKING, 2009). O emprego dos meios permitiu o isolamento de diferentes gêneros fúngicos, principalmente os mais importantes do ponto de vista toxigênico (Aspergillus, Penicillium, Fusarium e Alternaria) (Figura 16).

O Anexo A, a Tabela 7 e os Gráfico de 1 a 7 mostram os resultados da pesquisa da micobiota nas 140 amostras de grãos de trigo, nos diferentes meios de cultura.

Figura 136 - Colônias de fungos filamentosos isoladas de grãos de trigo, em meios DRBC (acima) e DG18 (abaixo).
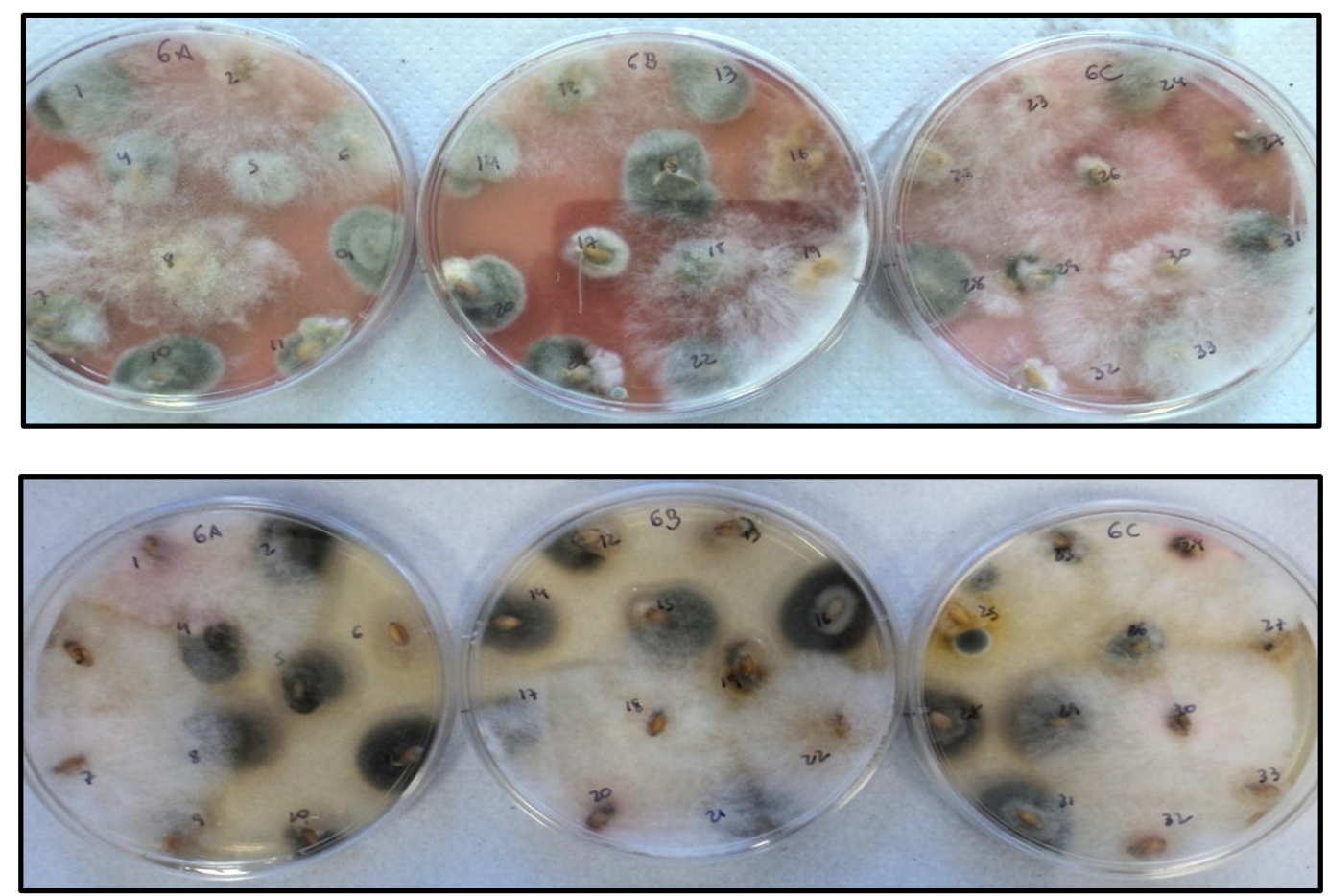
Constatou-se contaminação fúngica em $100 \%$ das amostras de trigo analisadas com porcentagem de grãos não contaminados (GNC) crescente com o tempo de armazenamento, variando de $1,2 \%$ na primeira coleta a $63,8 \%$ na última coleta.

Nossos estudos registraram, nas 140 amostras analisadas, maior frequiência de isolamento dos gêneros Alternaria (33,22\%), Epicoccum (12,6\%) e Fusarium (8,3\%), constatando-se maiores percentuais de contaminação nas amostras recém-colhidas, comparativamente às armazenadas (Tabela 7).

Outros 16 gêneros de fungos filamentosos foram isolados: Phoma (6,3\%), Cladosporium (4,9\%), Drechslera (3,7\%), Nigrospora (1,5\%), Aspergillus (1,4\%), Bipolaris (1,2\%), Penicillium (1,0\%), Acremonium (0,27\%), Pyrenophora (0,22\%), Mucor (0,13\%), Curvularia (0,1\%), Helminthosporium (0,09\%), Monographella (0,05\%), Rhizopus (0,04\%), Phomopsis $(0,03 \%)$ e Chaetomonium $(0,02 \%)$. Tais fungos, contaminantes usuais de cereais, são encontrados na maioria dos estudos com trigo de todo o mundo (GRABARKIEWICZSZCZENA; CHELKOWSKI; ZAJKOWSKI, 1989; KOBAYASTI; PIRES, 2011; MURRAY; BRENNAN, 2009). Alguns são citados como importantes causadores de manchas em grãos, a saber: Rhizopus stolonifer, Drechslera oryzae, Bipolaris sorokiniana, Pyricularia grizea, Alternaria padwickii, Phoma spp., Nigrospora spp., Pyrenophora teres, Epicocum spp., Curvularia lunata, Pyrenophora tritici-repentis (BRASIL, 2012c; KOBAYASTI; PIRES, 2011; MURRAY; BRENNAN, 2009).

Em nossa pesquisa, a elevada frequência de isolamento dos gêneros Alternaria, Epicoccum e Fusarium vem ao encontro dos achados de outros autores que também evidenciaram elevada freqüência de isolamento destes fungos no Brasil (BRANCÃO et al., 2008; KOBAYASTI; PIRES, 2011) e em diferentes países (AZCARATE et al., 2008; GRABARKIEWICZ-SZCZENA; CHELKOWSKI; ZAJKOWSKI, 1989; LI; YOSHIZAWA, 2000; PATRIARCA et al., 2007; WAGACHA et al., 2010). No que diz respeito ao gênero Epicoccum, o segundo fungo mais freqüente, a produção de micotoxinas é pouco conhecida, sendo relatada a produção de compostos tóxicos produzidos pela espécie E. sorghi. (PITT; HOCKING, 2009; STEYN et al. 1975).

A tendência de queda, durante o armazenamento, na freqüência de isolamento de Fusarium spp., considerado por Christensen e Sauer (1982) como "Fungo de Campo", coincide com os resultados obtidos por alguns autores, que realizaram monitoramento de fungos em grãos de milho e amendoim cultivados no Brasil (NAKAI et al., 2008 ; ZORZETE et al., 2011). 
Tabela 7 - Frequência média de isolamento de fungos, em grãos de trigo dos municípios de Capão Bonito e Avaré, nas 7 coletas.

\begin{tabular}{|c|c|c|c|}
\hline Patógenos & Média Capão Bonito & Média Avaré & Média Geral \\
\hline GNC & 28,45 & 34,75 & 31,60 \\
\hline Alternaria spp. & 37,68 & 28,77 & 33,22 \\
\hline Epicoccum spp. & 10,63 & 14,59 & 12,61 \\
\hline Phoma spp. & 5,02 & 7,64 & 6,33 \\
\hline Cladosporium spp. & 3,53 & 6,35 & 4,94 \\
\hline Nigrospora spp. & 1,08 & 1,84 & 1,46 \\
\hline Drechslera spp. & 2,12 & 5,26 & 3,69 \\
\hline Bipolaris spp. & 0,99 & 1,36 & 1,17 \\
\hline Penicillium spp. & 0,97 & 1,11 & 1,04 \\
\hline Aspergillus spp. & 1,71 & 1,11 & 1,41 \\
\hline Fusarium spp. & 12,36 & 4,33 & 8,35 \\
\hline Acremonium spp. & 0,15 & 0,39 & 0,27 \\
\hline Mucor spp. & 0,04 & 0,22 & 0,13 \\
\hline Rhizopus spp. & 0,02 & 0,07 & 0,04 \\
\hline Pyrenophora spp. & 0,19 & 0,24 & 0,22 \\
\hline Helminthosporium spp. & 0,04 & 0,13 & 0,09 \\
\hline Monographella spp. & 0,11 & 0,00 & 0,05 \\
\hline Chaetomonium spp. & 0,04 & 0,00 & 0,02 \\
\hline Phomopsis spp. & 0,00 & 0,07 & 0,03 \\
\hline Curvularia spp. & 0,09 & 0,11 & 0,10 \\
\hline FNE & 0,19 & 0,15 & 0,17 \\
\hline
\end{tabular}

GNC: grãos não contaminados; 
Gráfico 1- Frequência relativa $(\%)$ de isolamento dos diferentes fungos de grãos de trigo recém-colhidos em Capão Bonito e Avaré.

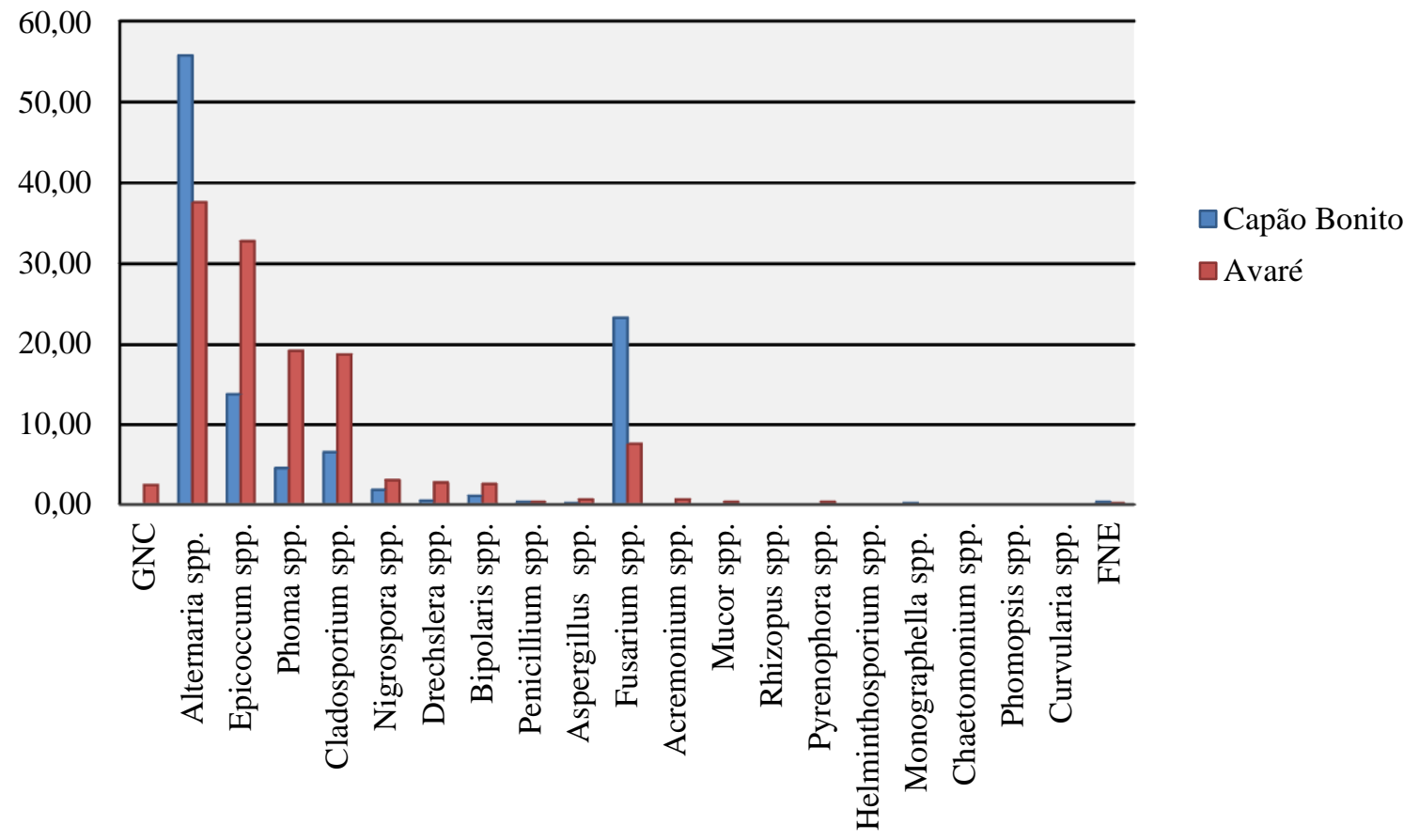

Gráfico 2 - Frequência relativa (\%) de isolamento dos diferentes fungos de grãos de trigo após o $1^{\circ}$ mês de armazenamento em Capão Bonito e Avaré.

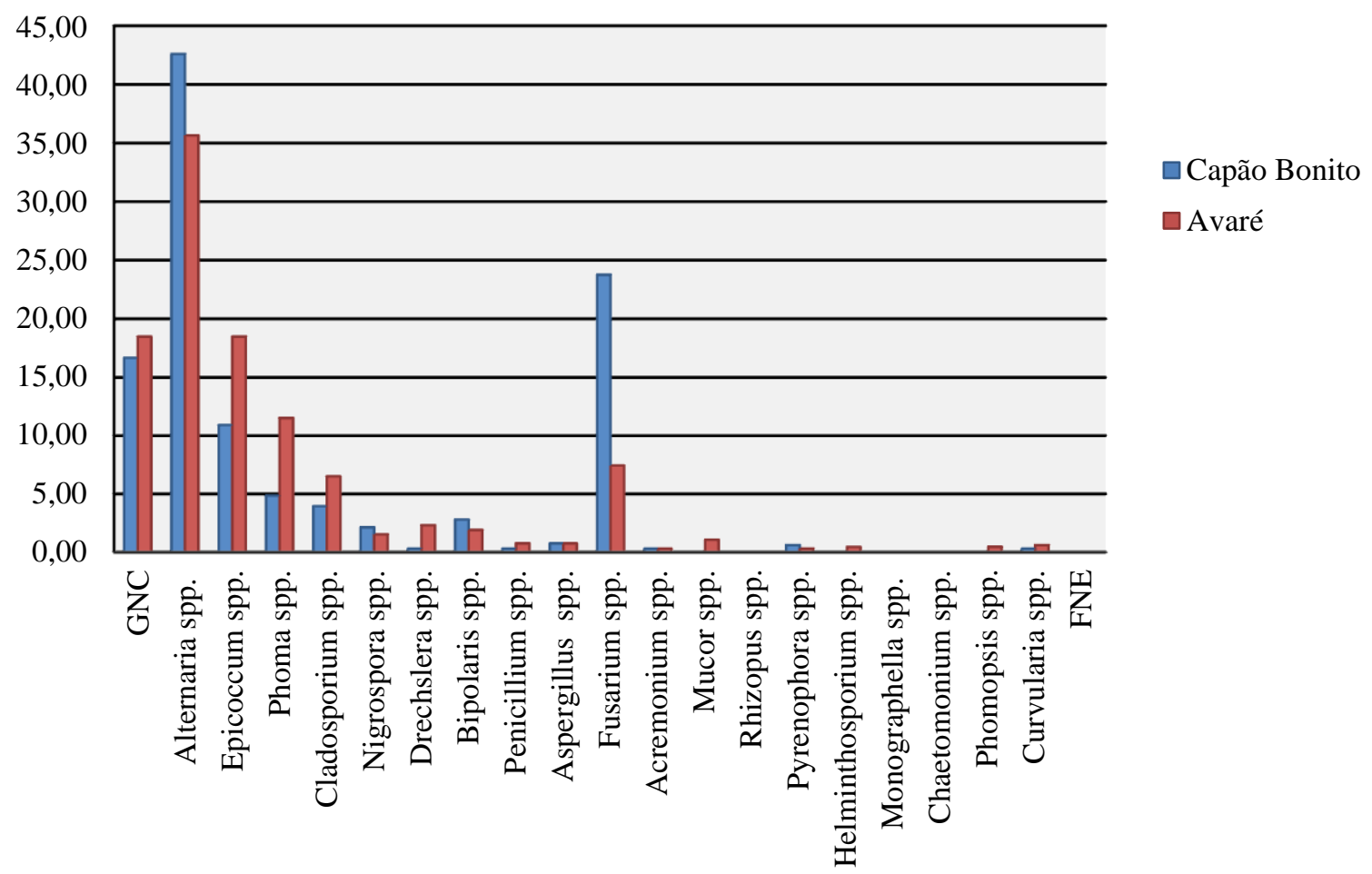


Gráfico 3 - Frequência relativa (\%) de isolamento dos diferentes fungos de grãos de trigo após o $2^{\circ}$ mês de armazenamento em Capão Bonito e Avaré.

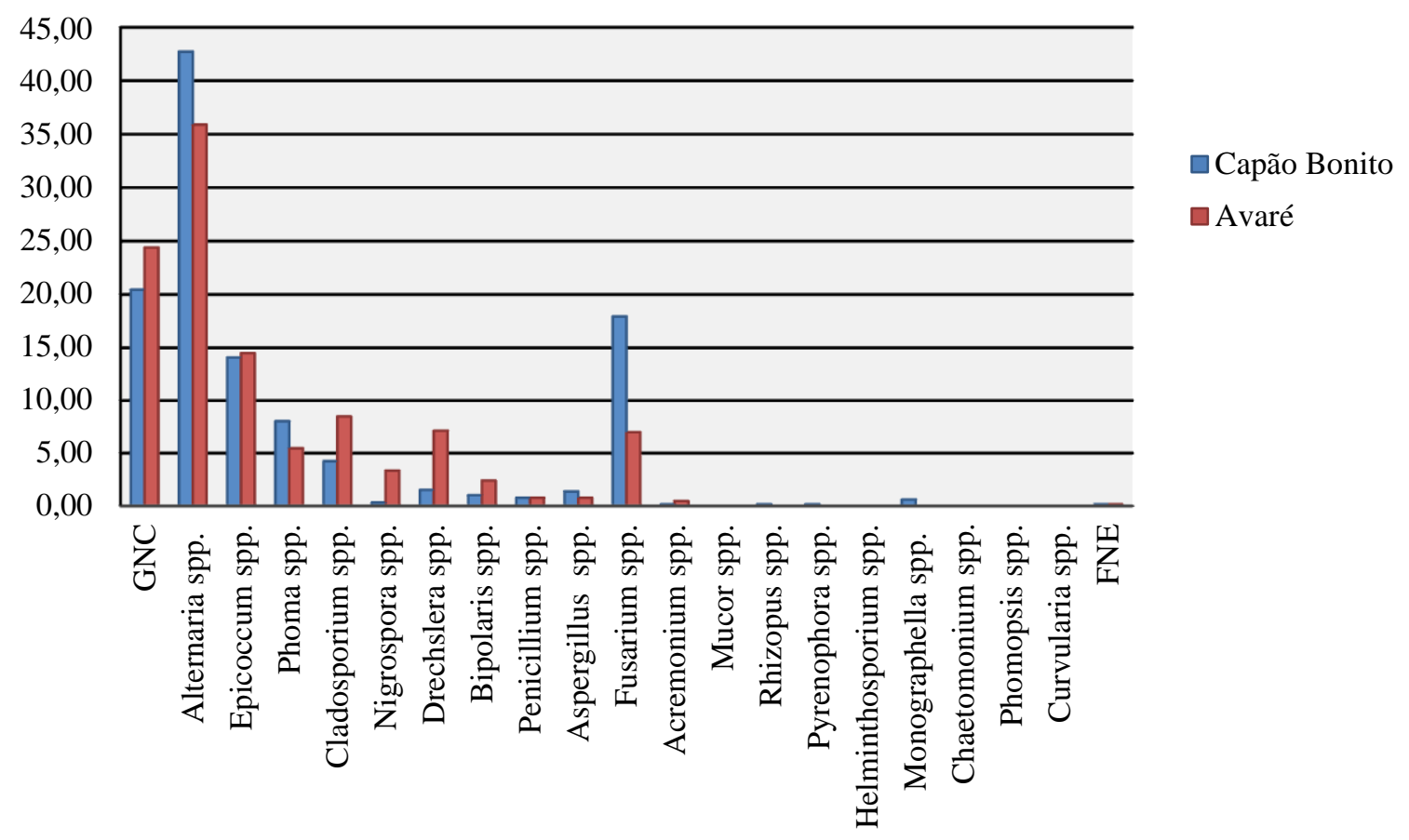

Gráfico 4 - Frequência relativa (\%) de isolamento dos diferentes fungos de grãos de trigo após o $3^{\circ}$ mês de armazenamento em Capão Bonito e Avaré.

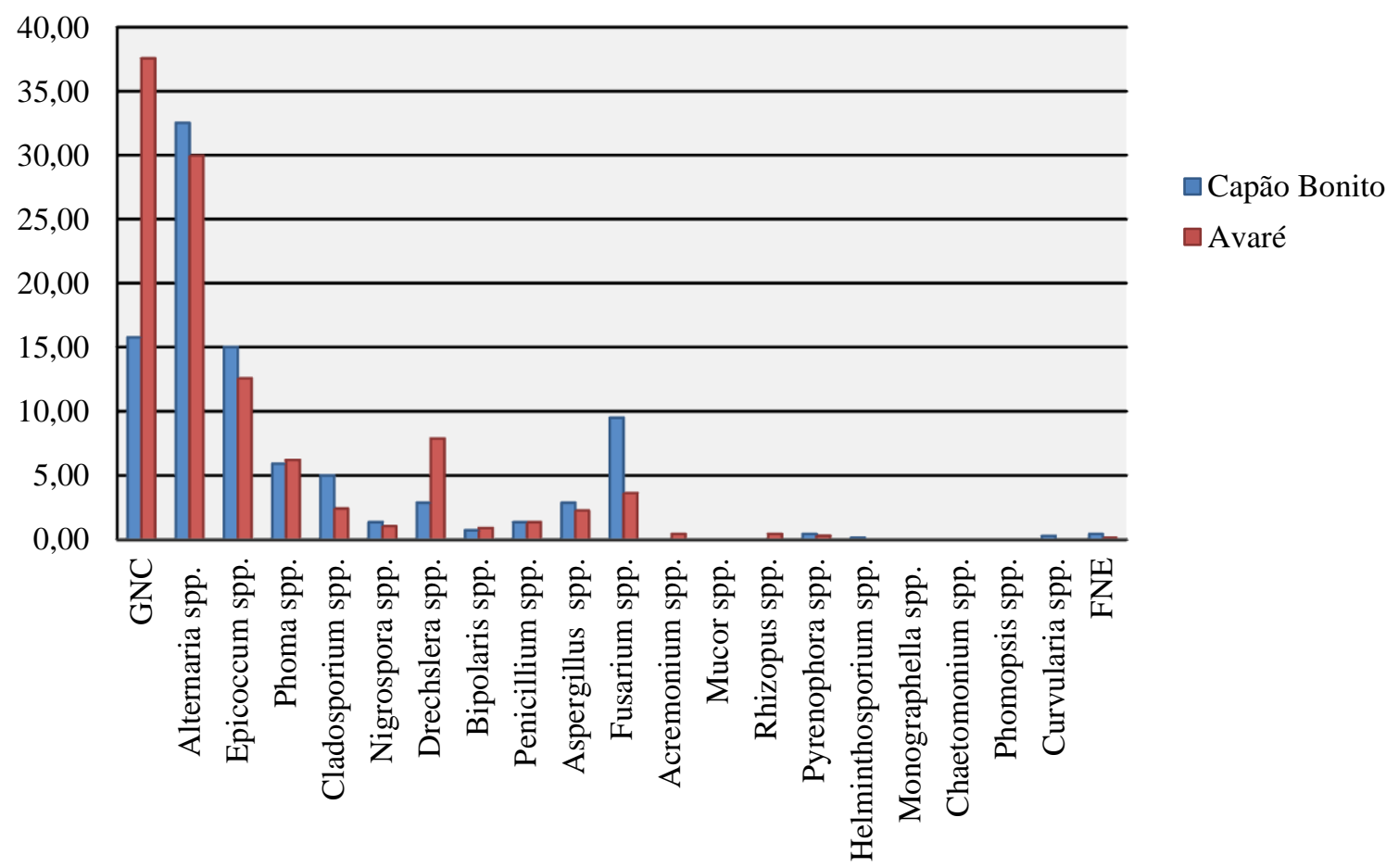


Gráfico 5 - Frequência relativa (\%) de isolamento dos diferentes fungos de grãos de trigo após o $4^{\circ}$ mês de armazenamento em Capão Bonito e Avaré.

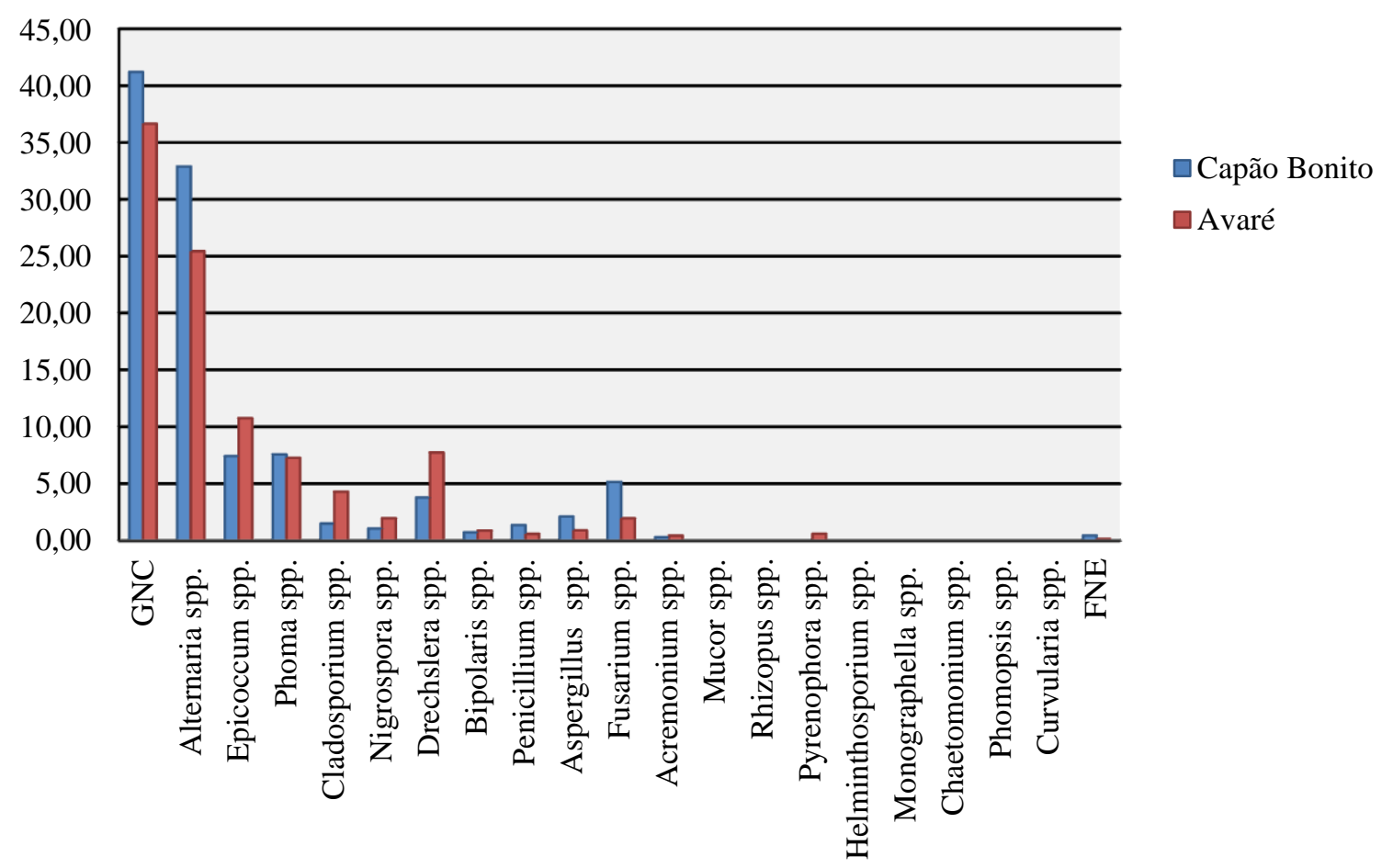

Gráfico 6 - Frequência relativa (\%) de isolamento dos diferentes fungos de grãos de trigo após o $5^{\circ}$ mês de armazenamento em Capão Bonito e Avaré.

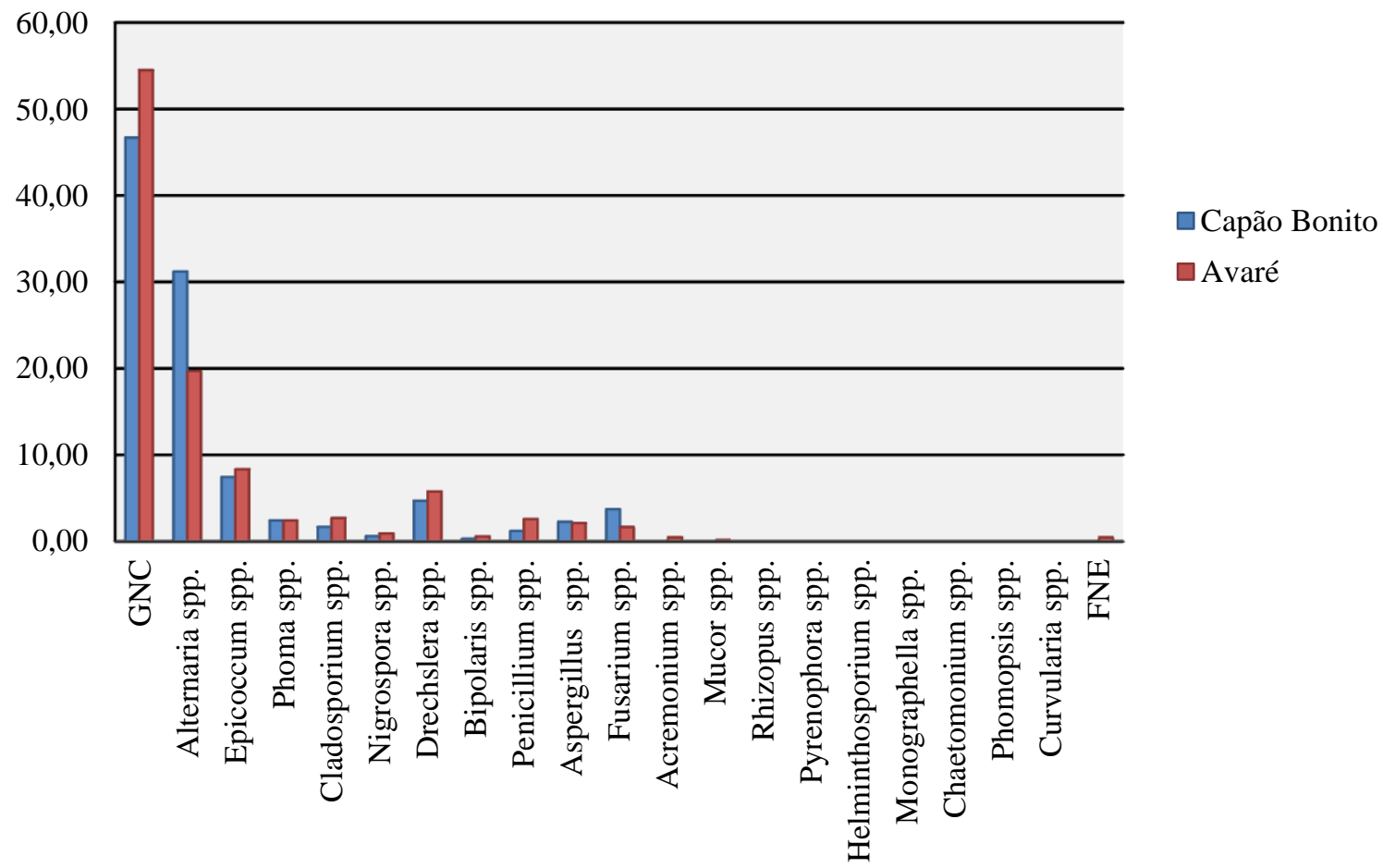


Gráfico 7 - Frequência relativa (\%) de isolamento dos diferentes fungos de grãos de trigo após o $6^{\circ}$ mês de armazenamento em Capão Bonito e Avaré.

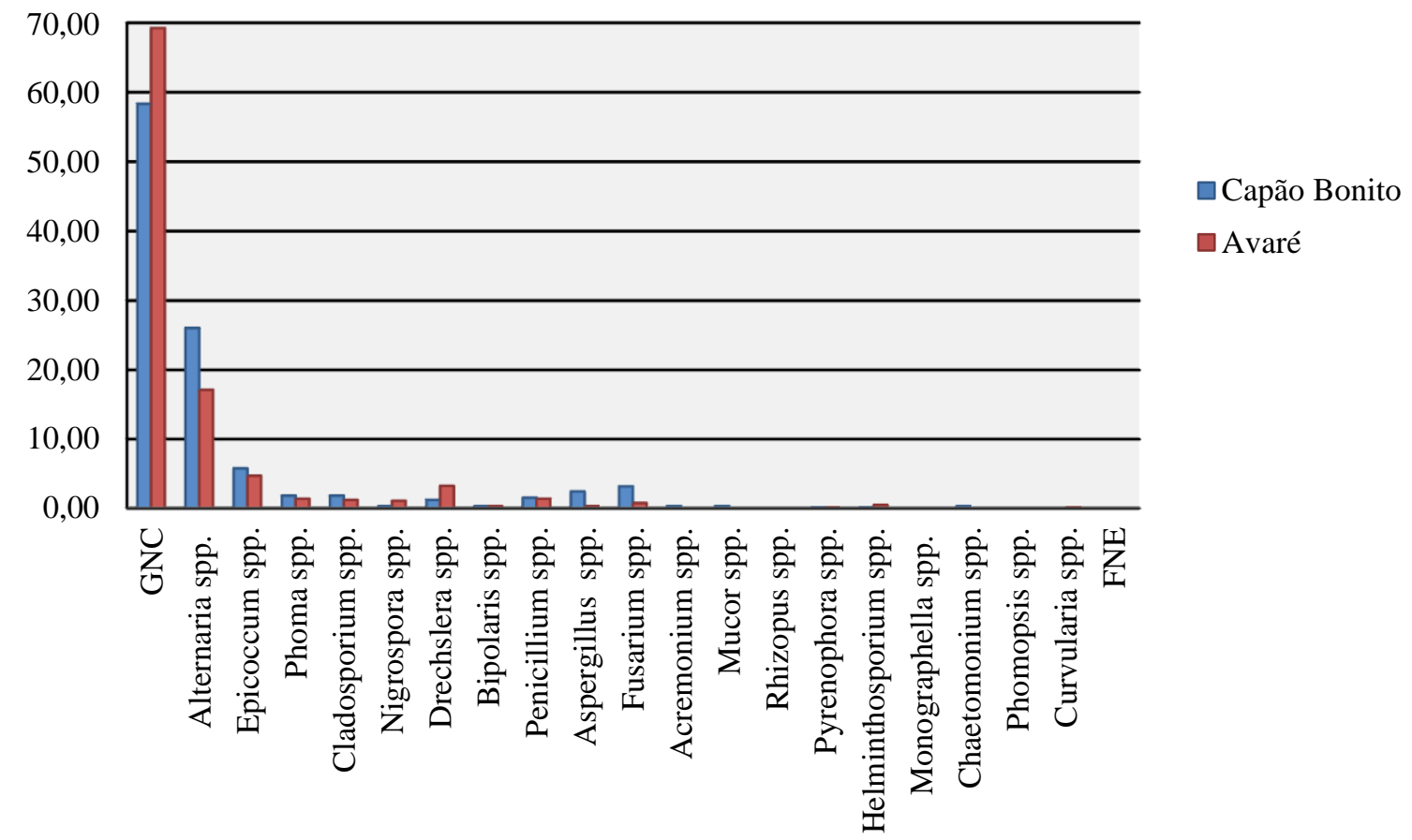

\subsubsection{Identificação dos isolados dos gêneros Fusarium e Alternaria no trigo recém-colhido e armazenado}

Os isolados de Fusarium spp. e Alternaria spp. identificados em nível de gênero através dos métodos morfológicos convencionais macro/micromorfológicos, foram submetidos à identificação molecular utilizando sequenciamento parcial do gene do fator de elongação 1- $\alpha$ (Fusarium spp.), e sequenciamento parcial do gene Alt a 1 (Alternaria sp.)

Dos 150 isolados de Fusarium spp. 85 (57\%) foram da região de Capão Bonito e 65 (43\%) da região de Avaré (local de menor contaminação fúngica). O emprego de técnica molecular, através da sequência parcial do gene do fator de elongação-1 $\alpha$,mostrou-se eficiente na caracterização das espécies de Fusarium, fato constatado anteriormente por GEISER et al. (2004). Segundo os autores, o referido gene possui elevada utilidade filogenética para distinção das espécies de Fusarium, devido ao elevado nível de polimorfismo, quando comparado com calmodulina, beta tubulina e histona H3. Dentro do gênero, a espécie $F$. graminerum foi a mais freqüente $(48,1 \%)$, nas amostras recém-colhidas e armazenadas. As demais espécies isoladas, em ordem decrescente de freqüência, foram: $F$. meridionale 
(20,2\%), F. incarnatum (16,6\%), F. verticillioides $(6,7 \%), F$. poae $(3,1 \%), F$. cortaderiae $(2,6 \%), F$. venenatum (1,6\%), F. boothi $(0,6 \%)$ e F. austroamericanum, $(0,5 \%)$ (Gráficos 8 e 9).

Dos 100 isolados de Alternaria sp. 60 (60\%) foram da região de Capão Bonito e 40 (40\%) da região de Avaré (local de menor contaminação fúngica). O emprego de técnica molecular, através da sequência parcial do gene Alt a 1, também mostrou-se eficiente na caracterização das espécies de Alternaria. Dentro do gênero, A. alternata foi a espécie mais frequente (40,3\%), seguido por A. longipes (21,9\%), A.tenuissima (17,3\%), A. arborescens (6,0\%), A. porri (5,0\%), A. brassicae (4,0\%), A. solani (2,7\%) e A. gaisen (2,1\%) (Gráficos 13 e 14).

Diferentemente de algumas regiões da Ásia, Europa e América do Norte, a distribuição, ocorrência e diversidade genética do complexo de espécies Fusarium graminearum em culturas de cereais na América do Sul não são tão bem compreendidas (ALVAREZ et al., 2011). Assim sendo, essas carências motivaram o estudo da frequência e da diversidade genética de isolados de Fusarium spp. no presente estudo.

Com base em sequências de DNA de 11 genes, O’Donnell et al. (2004), definiram que o complexo do Fusarium graminearum abrange 9 espécies com diferenciações morfológicas: (1) Fusarium graminearum sensu stricto, (2) Fusarium meridionale, (3) Fusarium austroamericanum, (4) Fusarium boothii, (5) Fusarium cortaderiae, (6) Fusarium acácia mearnsii, (7) Fusarium asiaticum, (8) Fusarium brasilicum e (9) Fusarium mesoamericanum. As espécies de (1) a (5) foram encontradas no presente estudo e são normalmente isoladas na América do Sul, sendo que $F$. boothii e $F$. graminearum não apresentam distribuição geográfica definida.

F. graminearum sensu stricto, predominante no trigo, é amplamente distribuída na América do Norte, do Sul e na Europa (ALVAREZ et al., 2011; GAGKAEVA; YLIMATTILA, 2004; O’DONNELL et al., 2004). No entanto, diversos estudos mostraram que outras espécies do complexo podem co-ocorrer com F. graminearum nas mesmas áreas geográficas, como F. meridionale e F. cortaderiae (MONDS et al., 2005; SCOZ et al., 2009).

Dentro do gênero Fusarium, as duas espécies de maior predominância neste estudo, Fusarium graminearum sensu stricto e Fusarium meridionale, têm sido associadas à Giberela na região Sul do Brasil, cada uma possuindo um genótipo de tricotecenos distinto (ASTOLFI et al., 2011, 2012; SCOZ et al., 2009). 
Gráfico 8 - Frequência relativa (\%) de isolamento das diferentes espécies de Fusarium em Capão Bonito.

\section{Capão Bonito}

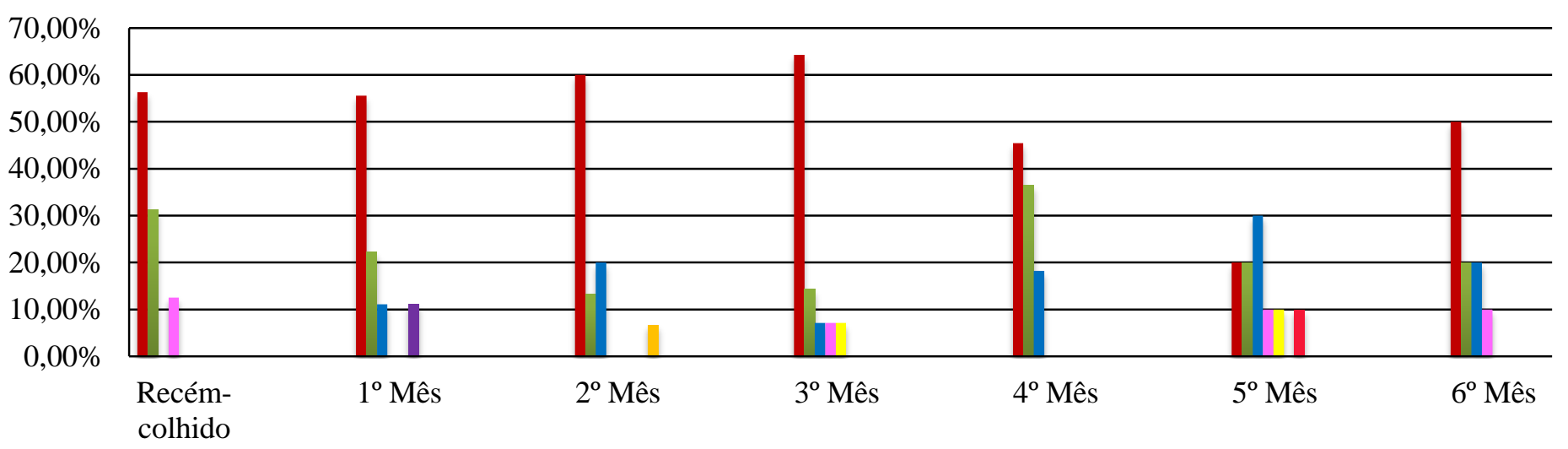

Gráfico 9 - Frequência relativa (\%) de isolamento das diferentes espécies de Fusarium em Avaré.

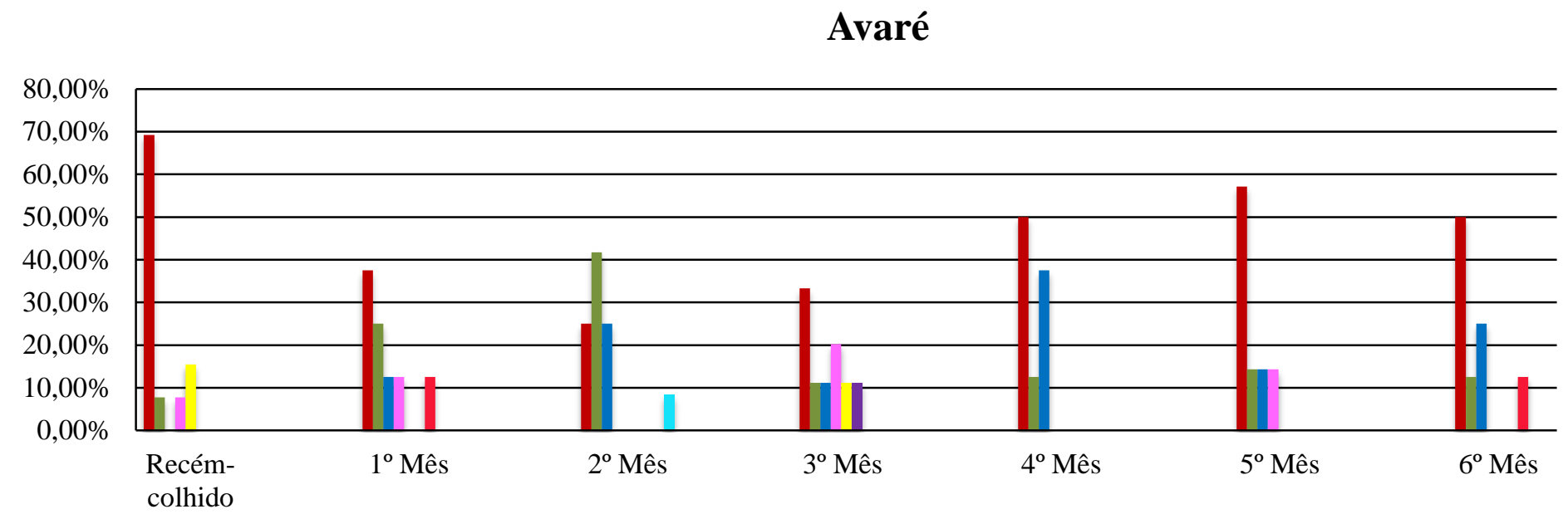

- Fusarium graminearum

Fusarium meridionale

- Fusarium incarnatum

Fusarium verticillioides

Fusarium poae

- Fusarium venenatum

- Fusarium cortaderiae

Fusarium austroamericanum

Fusarium boothi

\section{- Fusarium graminearum}

- Fusarium meridionale

- Fusarium incarnatum

Fusarium verticillioides

Fusarium poae

- Fusarium venenatum

- Fusarium cortaderiae

- Fusarium austroamericanum

- Fusarium boothi 
A produção de micotoxinas no complexo $F$. graminearum não é espécie específica, mas restrita a um subconjunto de espécies (MONDS et al., 2005). A produção de tricotecenos por espécies do complexo de $F$. graminearum já foi relatada em muitos estudos ao redor do mundo (ALVAREZ, et al., 2011; O’DONNELL et al., 2004; SAMPIETRO et al., 2010; SCOZ et al., 2009).

Segundo Goswami e Kistler (2005), F. boothii, F. austroamericanum, F. asiaticum e $F$. graminearum são produtores de DON enquanto $F$. meridionale, $F$. acaciae-mearnsii e $F$. cortaderiae são produtores de nivalenol.

Dentre as espécies isoladas, Fusarium incarnatum, Fusarium verticillioides, Fusarium poae e Fusarium venenatum não fazem parte do complexo F. graminearum. No entanto, também são produtoras de micotoxinas (KOSIAK; TORP; THRANE, 1997; O’DONNELL et al., 1998; PERKOWSKI et al., 1997; THRANE; HANSEN, 1995; TURNER; JENNINGS, 1997).

As infecções causadas por $F$. graminearum podem afetar tanto aspectos físicos quanto fisiológicos da semente, incluindo o seu tamanho, peso, composição e qualidade (BECHTEL et al. 1985), permitindo que ocorram severas perdas no rendimento, as quais podem ser superiores a 50\%, além de afetar a qualidade dos grãos susceptíveis (SNIJDERS, 1990).

Gráfico 10 - Frequência relativa (\%) de isolamento de Fusarium spp. nas regiões de estudo.

\section{Fusarium spp.}

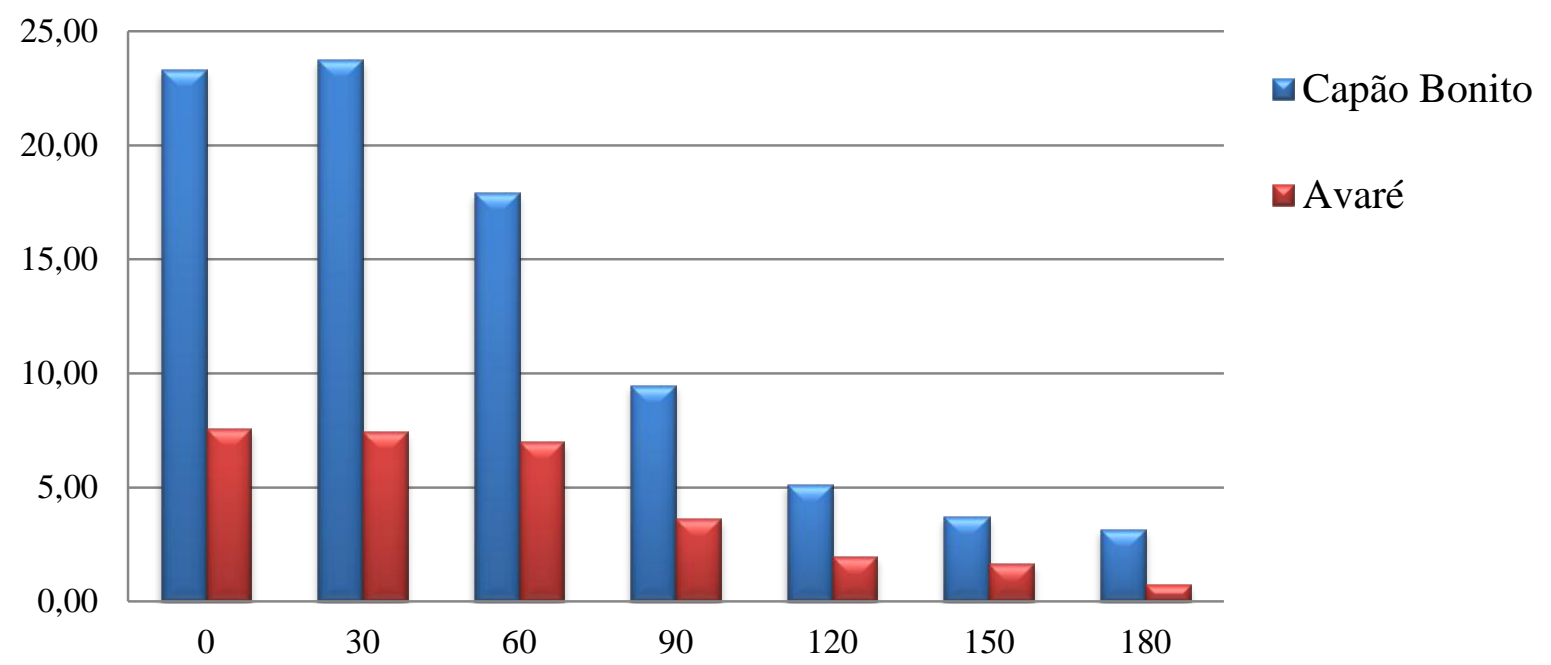


Gráfico 11 - Frequência relativa (\%) de isolamento de Fusarium spp. nos diferentes meios de cultura, nas amostras de Capão Bonito.

\section{Capão Bonito}

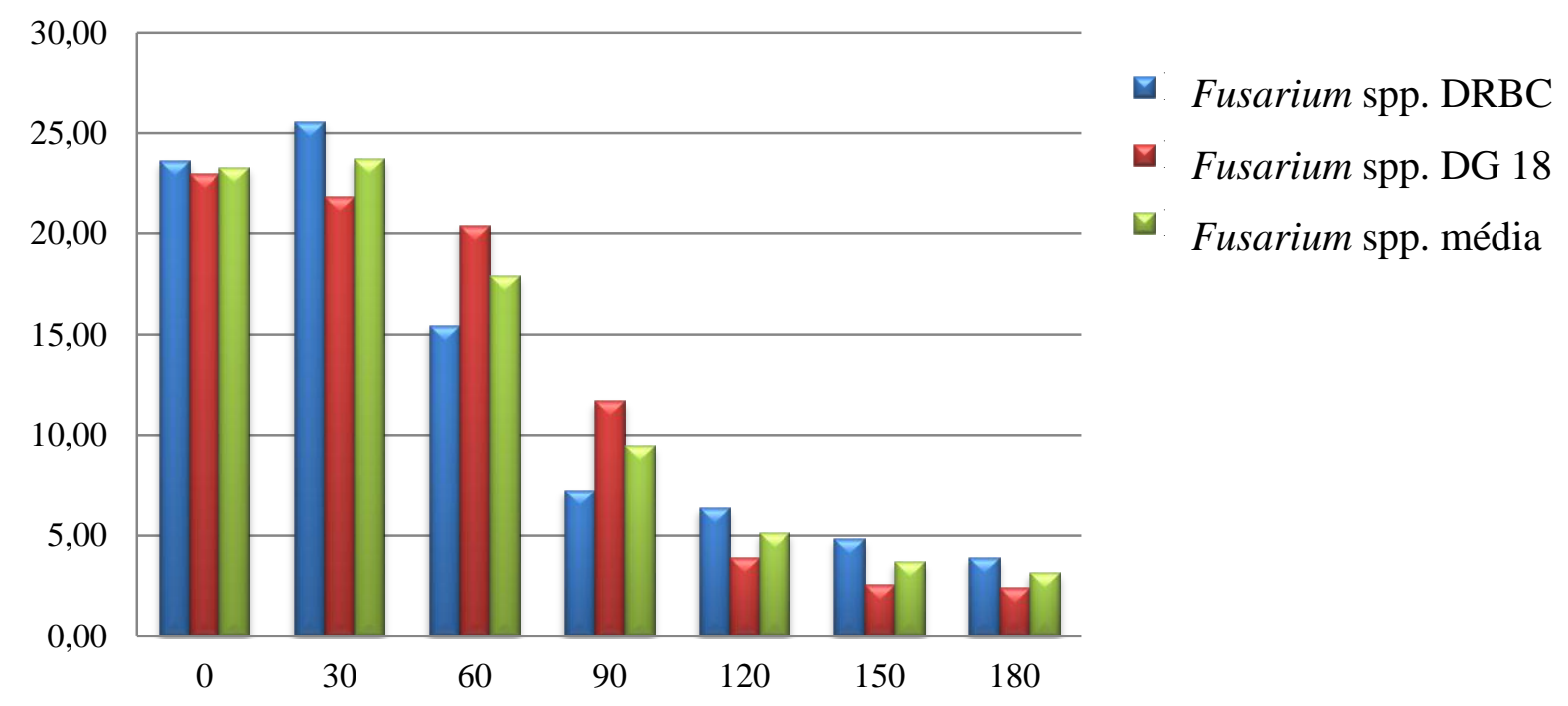

Gráfico 12 - Frequência relativa (\%) de isolamento de Fusarium spp. nos diferentes meios de cultura, nas amostras de Avaré.

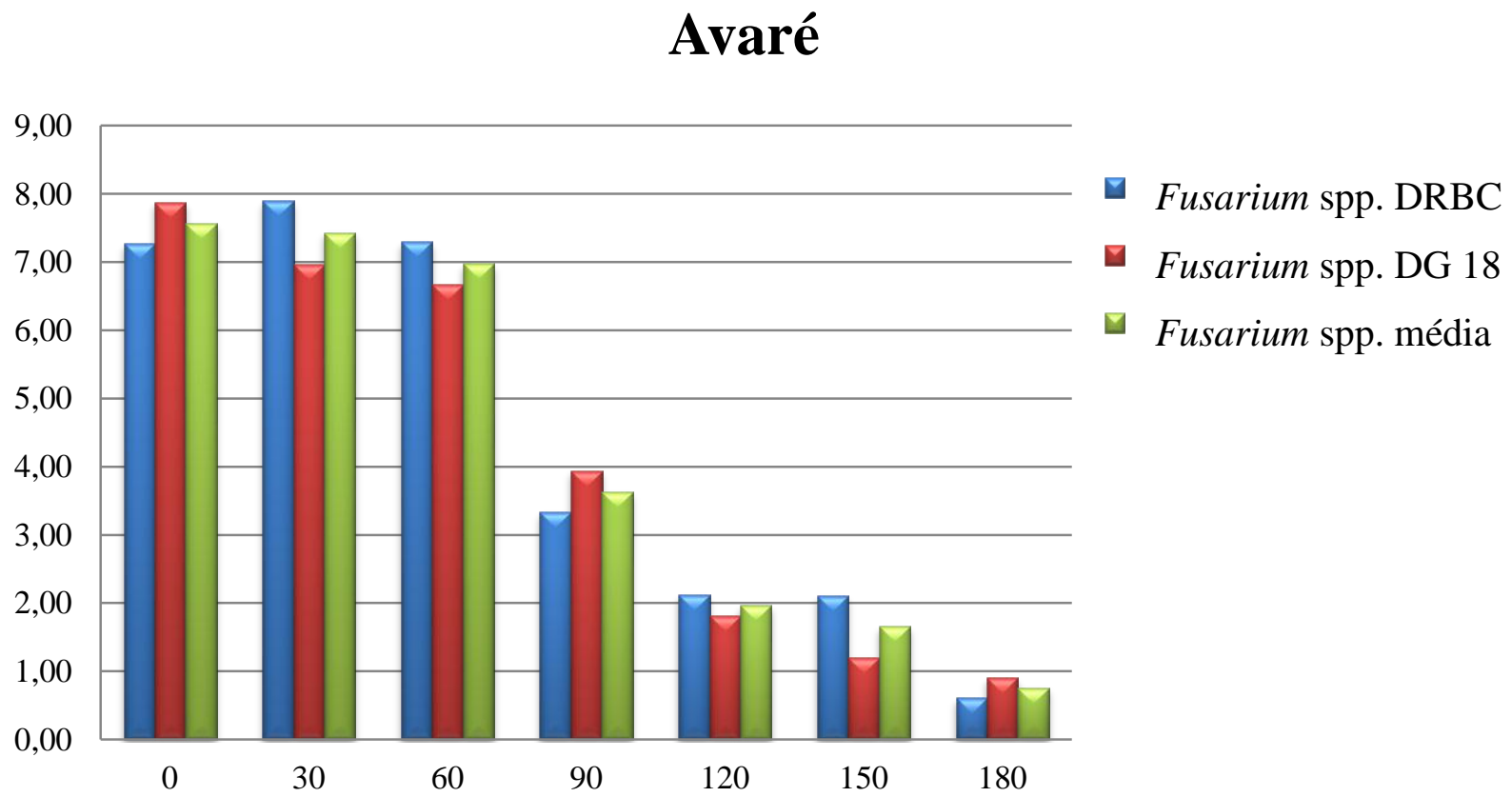


As espécies de Alternaria são associadas com uma vasta gama de doenças em muitas plantas de elevado valor alimentar. Cancro da haste, mancha foliar e ponto preto são sintomas bem conhecidos, como resultado de uma infecção de diferentes plantas hospedeiras por espécies de Alternaria (BOTTALICO; LOGRIECO, 1998; LOGRIECO; MORETTI; SOLFRIZZO, 2009) Alternaria alternata produz doenças nas culturas, como o bolor negro de tomate, podridão negra de oliva e frutas cítricas e o ponto preto de pequenas cereais (GIRYN; SZTEKE, 1995; LOGRIECO et al., 2003;. POZZI et al., 2005), além da produção de ácido tenuazônico (TEA), alternariol (AOH), alternariol mono-metiléter (EMA) e altenuene (ALT) em produtos alimentícios (PAVÓN et al., 2012).

São conhecidas, atualmente, cerca de 300 espécies de Alternaria o que torna sua classificação muito complexa. A identificação de Alternaria spp. por métodos morfológicos clássicos exige muita experiência em morfologia, além de ser um processo tedioso e demorado (SIMMONS, 2007). Em contraste, os métodos moleculares, baseados principalmente na reação em cadeia da polimerase (PCR), são rápidos e sensíveis e oferecem abordagens alternativas para a identificação de microorganismos deterioradores de alimentos (PAVÓN et al., 2012; PAVÓN et al., 2010).

Um dos marcadores genéticos utilizados para a identificação de espécies são os genes codificadores de proteínas, como Alt a 1 (HONG et al., 2005). Alt a é um gene que codifica o principal alérgeno produzido por A. alternata, Alt a 1 (PAVÓN et al., 2010).

Alternaria alternata é a espécie mais comum em commodities agrícolas, porém outras espécies também podem ser produtoras de micotoxinas em alimentos, como A. citri, A. solani, A. longipes e o grupo de espécies A. tenuissima, arborescens e A. infectoria (BARKAIGOLAN; PASTER, 2013).

Estudos filogenéticos e padrões de esporulação propõem o agrupamento de espécies de Alternaria em vários grupos (CHOU; WU, 2002; HONG et al., 2005; SIMMONS, 2007): 1) O grupo de espécies A. alternata inclui espécies como A. alternata, A. arborescens, $A$. tenuissima, A. gaisen, A. citri, e A. longipes. Estas são produtoras de micotoxinas como alternariol $(\mathrm{AOH})$, éter metil alternariol (AME) e ácido tenuazônico (TEA) (ANDERSEN; KROGER; ROBERTS, 2001, 2002) e são responsáveis pela grande deterioração de plantas e vegetais, resultando em consideráveis perdas econômicas para os produtores e para a indústria de processamento de alimentos. 2) O grupo A. porri inclui espécies como A. solani, A. porri, A. dauci e A. tomatophila, que são responsáveis por pragas foliares de cenouras, cebolas, batatas, e tomates e produzem micotoxinas como $\mathrm{AOH}$, Altertoxins e altersolanol (ANDERSEN; DONGO; PRYOR, 2008). 3) O grupo Alternaria radicina é considerado um 
Gráfico 13 - Frequência relativa (\%) de isolamento das diferentes espécies de Alternaria em Capão Bonito

Capão Bonito

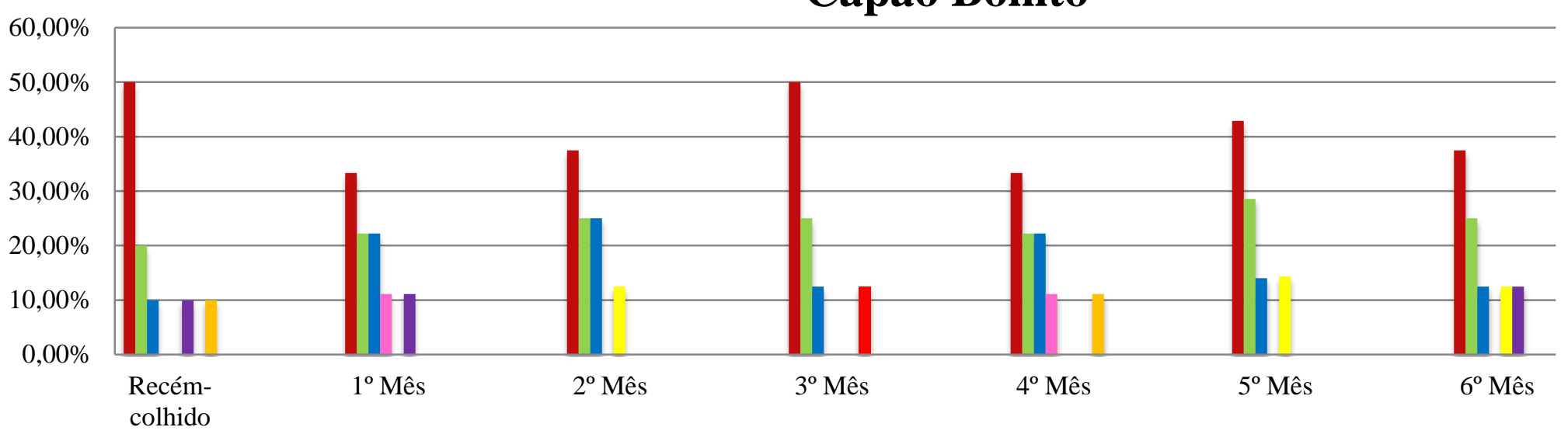

- Alternaria alternata Alternaria longipes

- Alternaria tenuissima

- Alternaria brassicae

Alternaria arborescens

- Alternaria porri

- Alternaria gaisen

$\square$ Alternaria solani

Gráfico 14 - Frequência relativa (\%) de isolamento das diferentes espécies de Alternaria em Avaré.

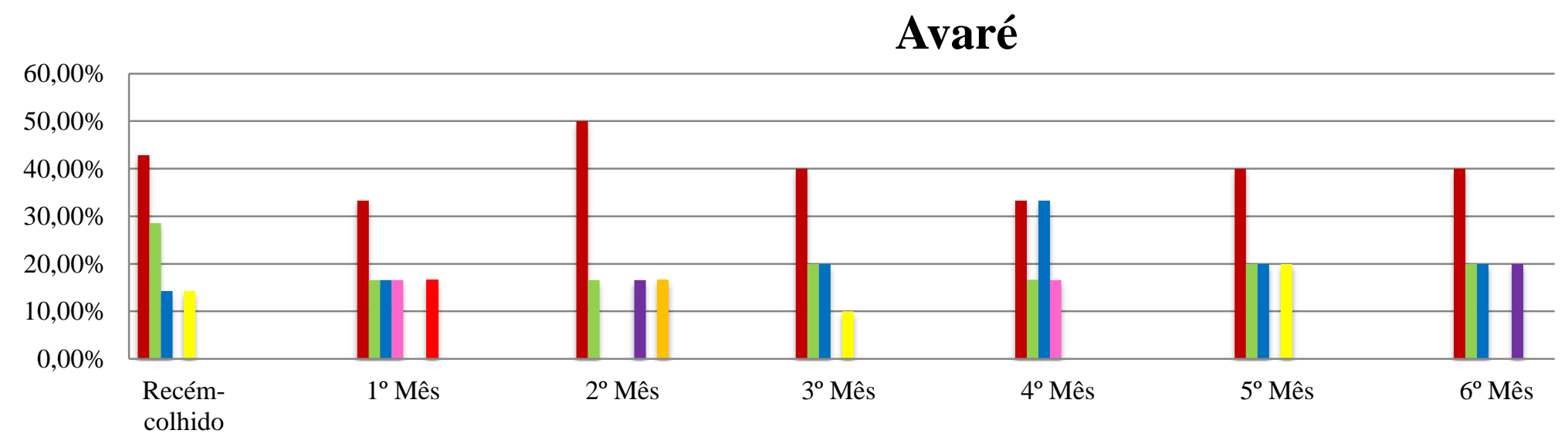

- Alternaria alternata Alternaria longipes

- Alternaria tenuissima - Alternaria brassicae

Alternaria arborescens

- Alternaria porri

- Alternaria gaisen

- Alternaria solani 
dos mais importantes patógenos transmitidos pela semente e as espécies produzem compostos fitotóxicos como Radicinin e radicinol (KONSTANTINOVA et al., 2002; SOLFRIZZO et al., 2005; TYLKOWSKA,1992). 4) As espécies do grupo Alternaria infectoria afeta cultura de cereais no campo e durante o armazenamento, e produzem metabólitos como infectopyrones e novae-zelandins que não são encontrados nos outros grupos (ANDERSEN et al., 2009; CHRISTENSEN et al., 2005).

O fungo A. brassicae é um importante patógeno que causa principalmente manchas e/ou lesões foliares. Estas manchas são circulares, zonadas, com o centro cor de palha e em geral com um halo clorótico (HUMPHERSON-JONES, 1992; MARINGONI, 1997). Aparentemente, o primeiro registro formal deste fungo foi feito na Coréia, causando manchas foliares em espécies de brássicas (NAKATA; TAKIMOTO, 1928). No Brasil, este patógeno já foi relatado como causador de manchas foliares em pelo menos 14 espécies de plantas (MENDES et al., 1998).

Gráfico 15 - Frequência relativa (\%) de isolamento de Alternaria spp. nas regiões de estudo.

\section{Alternaria spp.}

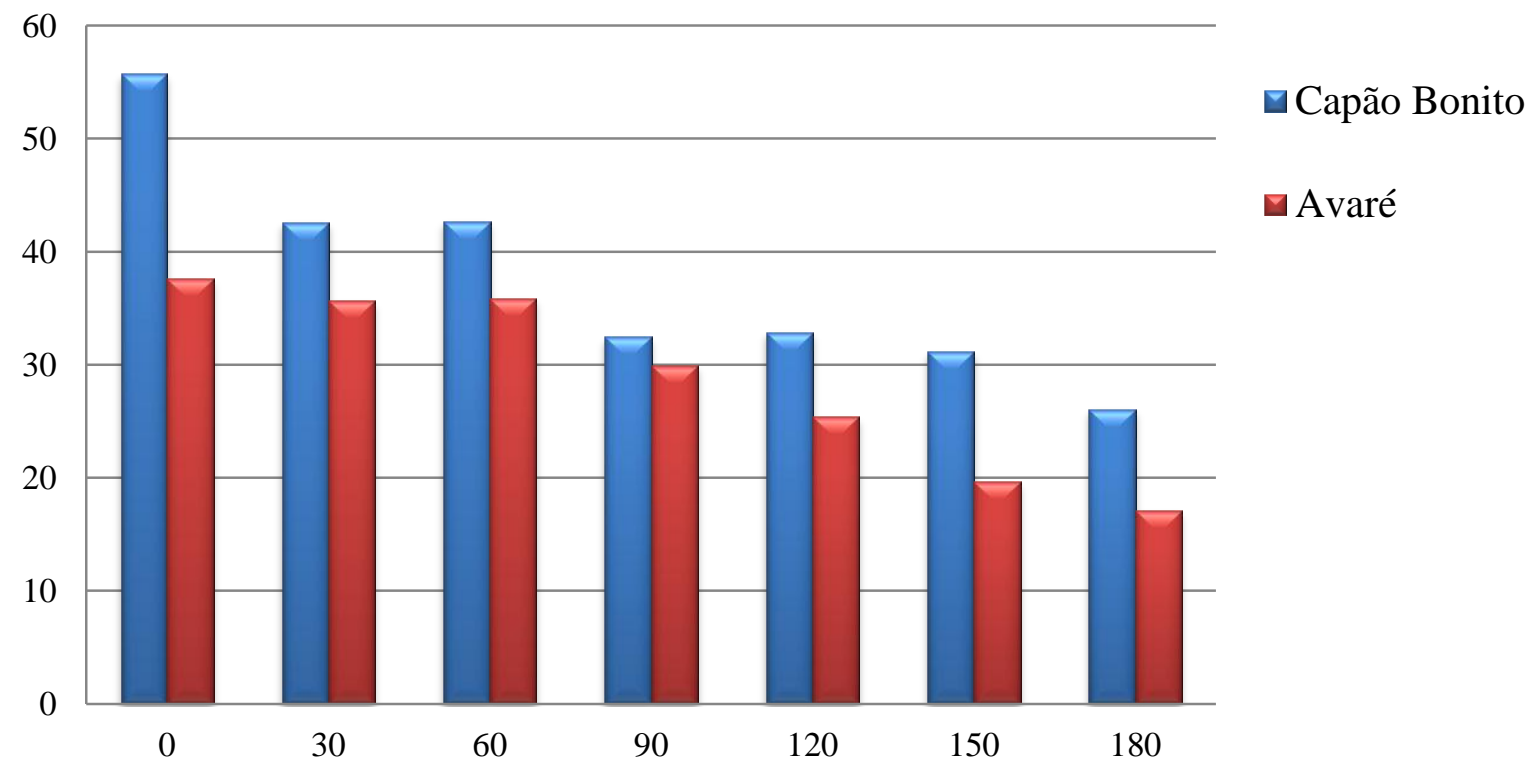


Gráfico 16 - Frequência relativa (\%) de isolamento de Alternaria spp. nos diferentes meios de cultura, nas amostras de Capão Bonito.

\section{Capão Bonito}

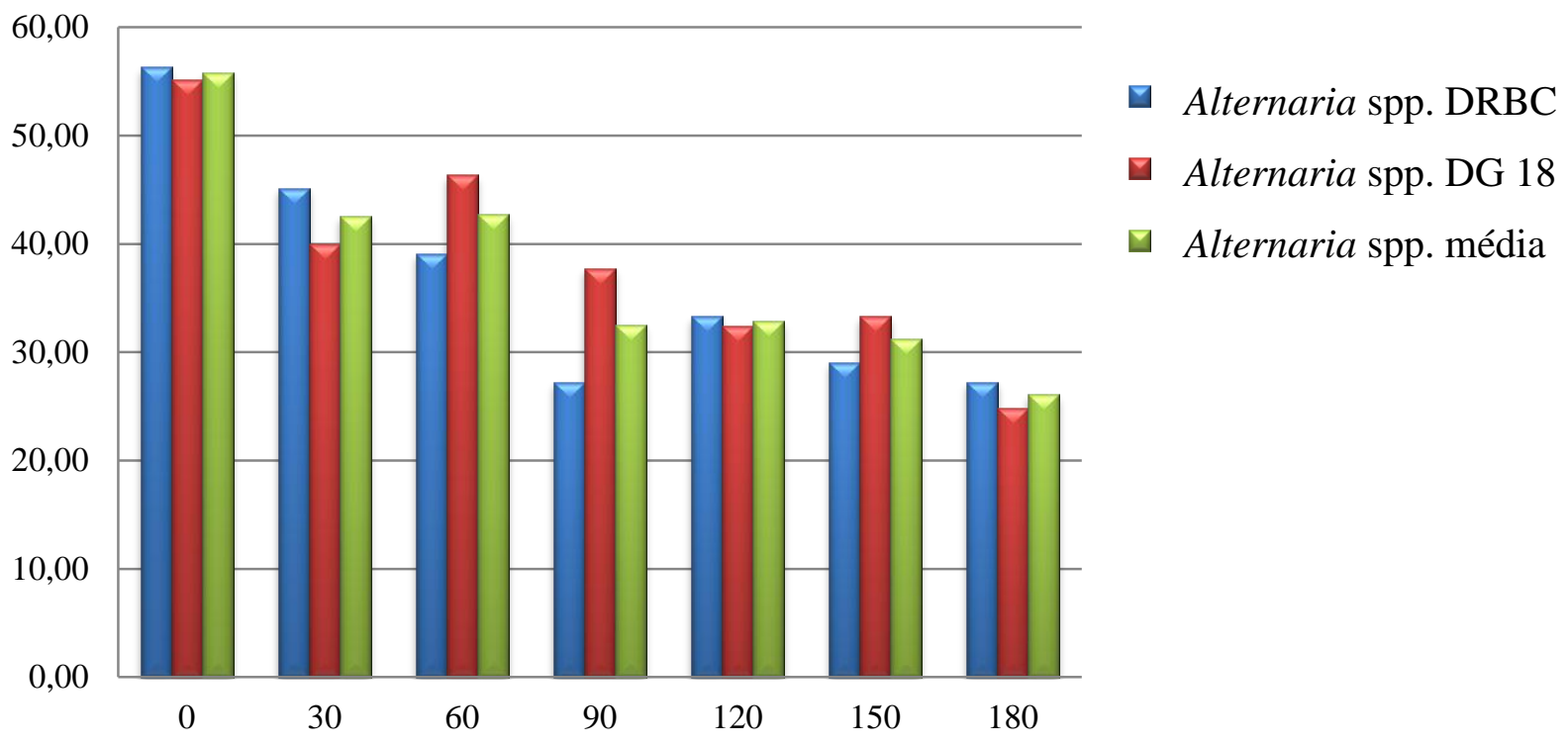

Gráfico 17 - Frequência relativa (\%) de isolamento de Alternaria spp. nos diferentes meios de cultura, nas amostras de Avaré.

Avaré

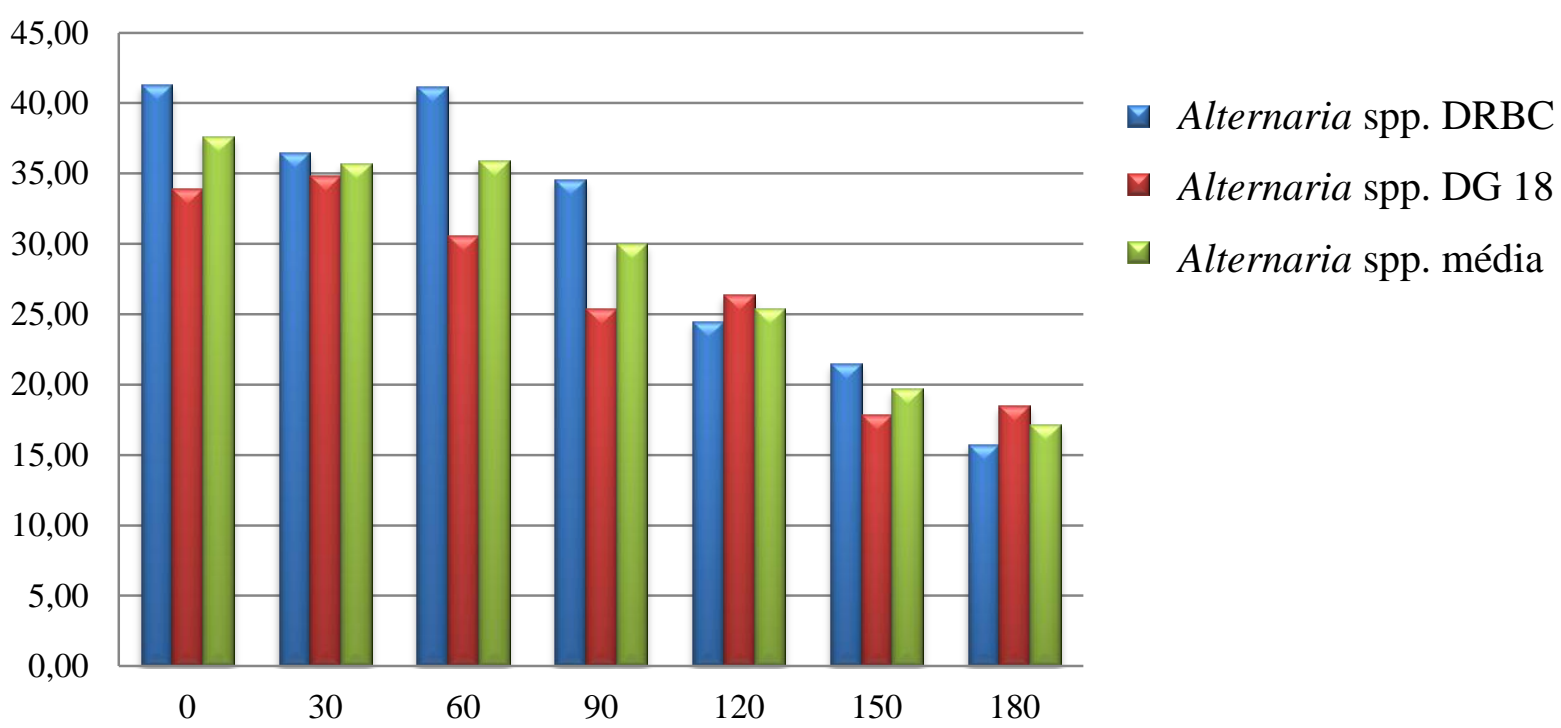




\subsection{ATIVIDADE DE ÁGUA E CONDIÇÕES CLIMÁTICAS}

Os dados climatológicos (temperatura e precipitação), obtidos junto às estações meteorológicas localizadas na própria região de estudo, estão apresentados na Tabela 8.

A atividade de água e a contaminação fúngica foram verificadas a cada coleta, enquanto a temperatura foi obtida pela média mensal da média diária. $\mathrm{O}$ índice pluviométrico foi obtido pela média mensal, sendo que no caso dos grãos recém-colhidos a média foi extraída do mês pré-colheita.

Todas as variáveis, temperatura, índice pluviométrico, dias com chuva, atividade de água e \% de contaminação dos fungos de interesse, foram normalizadas e simbolizadas por (*). A normalização é feita através da divisão da média pelo valor máximo do parâmetro, V/Vmáx., obtendo-se assim, valores adimensionais que facilitam a visualização, os cálculos e permitem a comparação entre eles (Tabela 8).

Através da normalização, verificou-se que a partir do terceiro mês de armazenamento (90 dias), a diminuição crescente na Aa implicou em quedas mais bruscas na porcentagem de contaminação de Alternaria spp., e ainda mais acentuada para Fusarium spp., tanto em Capão Bonito quanto em Avaré (Gráficos 18 e 19).

As regiões produtoras de trigo caracterizam-se por apresentar condições climáticas favoráveis ao desenvolvimento de doenças de importância econômica para a cultura (FORCELINI ; REIS, 1997; LUZ, 1982). Dentre os fatores abióticos que influenciam no crescimento fúngico e na produção de micotoxinas nos grãos, destacam-se a quantidade de água livre disponível, expressa em atividade de agua (Aa) e a temperatura, sendo evidente a importância de avaliar o comportamento dos diferentes microrganismos frente a estes fatores (ALMEIDA et al., 2002).

Em nossa pesquisa, em relação à atividade de água e temperatura, os valores médios registrados na colheita foram: Capão Bonito $\left(\mathrm{Aa}=0,75\right.$ e $\left.16,1{ }^{\circ} \mathrm{C}\right)$ e Avaré (Aa=0,62 e 20,4 ${ }^{\circ} \mathrm{C}$ ). Durante o armazenamento, os valores encontrados foram: Capão Bonito ( $\mathrm{Aa}=0,67 \mathrm{a}$ 0,53; temperatura 22,7 a $24,8{ }^{\circ} \mathrm{C}$ ); Avaré ( $\mathrm{Aa}=0,58$ a 0,54 ; temperatura 20,5 a $24,5{ }^{\circ} \mathrm{C}$ ). Os níveis de atividade de água situaram-se abaixo dos estabelecidos por Lacey et al. (1991), para o crescimento de $F$. gramineaum $(0,89)$ e A. alternata $(0,88)$; e para a produção de DON e ZEA $(0,98)$ e AOH $(0,90)$ (Tabela 8$)$. Vale frisar que os valores de Aa para a produção de micotoxinas são, frequentemente, maiores do que aqueles necessários para o crescimento dos fungos produtores.(LACEY et al. 1991). No que diz respeito à temperatura, excetuando-se os 
valores registrados durante a colheita, os níveis témicos registrados podem ser considerados ótimos (LACEY et al., 1991).

A colonização de grãos por Fusarium spp. requer elevada Aa, geralmente acima de 0,90 (MAGAN et al., 2010; RAMIREZ; CHULZE; MAGAN, 2006). A espécie $F$. graminearum é favorecida pela umidade contínua e temperaturas de 20-30 ${ }^{\circ} \mathrm{C}$ (DIEKMANN; PUTTER, 1995). A. alternata, requer temperaturas entre $6-36{ }^{\circ} \mathrm{C}$ para se desenvolver, com ótimo próximo a $25{ }^{\circ} \mathrm{C}$ (DOMSCH; GAMS; ANDERSON, 1980; HASIJA, 1970). A Aa mínima para seu crescimento a $25^{\circ} \mathrm{C}$, é de 0,86 (HOCKING, 1994).

Em nosso estudo, o decrécimo na frequência de isolamento de Alternaria spp.e Fusarium spp. durante o armzenamento,em ambas as regiões, pode ser atribuído à diminuição dos níveis de atividade de água das amostras, situados entre 0,75 e 0,53 (Tabela 8). Este fato já foi constatado por outros autores analisando milho e sorgo cultivados no Brasil (MAGAN et al., 2010; POZZI et al., 1995; RAMIREZ; CHULZE; MAGAN, 2006; SILVA et al., 2000).

O desenvolvimento fúngico em baixa Aa pode ser explicado pela capacidade dos mesmos em adquirir forma latente quando em condições adversas e, após exposição a condições ótimas durante a análise (meio de cultura, temperatura e umidade), os fungos voltam a se desenvolver.

É evidente uma queda acentuada na contaminação a partir do terceiro mês de armazenamento nas amostras de Capão Bonito, o que pode ser justificada pelo processo de beneficiamento ocorrido nesse período. A menor incidência fúngica nas amostras de Avaré pode ser devido ao mesmo motivo pois as mesmas haviam sido beneficiadas desde a primeira coleta.

Outros fatores importantes que afetam a distribuição de fungos são interações fúngicas, incluindo competição espacial entre os gêneros Alternaria e Fusarium. Alternaria spp. compete espacialmente com outros fungos na superfície da planta e é antagônica aos gêneros Cladosporium, Epicoccum e Fusarium (LACEY et al., 1991). Júnior, Vechiato e Menten (2008) relataram que a detecção de F. graminearum pode ser prejudicada pela alta incidência de fungos saprofíticos, como Alternaria spp. Assim como relatado por estes autores, foi observada a competição relatada entre Alternaria spp. e Fusarium spp., resultando em dificuldades no isolamento. 
Tabela 8 - Dados de temperatura média $\left({ }^{\circ} \mathrm{C}\right)$ e índice pluviométrico médio (mm) referentes aos meses de agosto (2011) a março (2011), registrados das regiões de Capão Bonito e Avaré, São Paulo.

\begin{tabular}{|c|c|c|c|c|c|c|c|c|c|}
\hline \multirow{2}{*}{ Localidade } & \multirow{2}{*}{ Variável } & \multicolumn{8}{|c|}{ Mês } \\
\hline & & Setembro & Outubro & Novembro & Dezembro & Janeiro & Fevereiro & Março & Abril \\
\hline \multirow{8}{*}{ Capão Bonito } & $\mathrm{mmH}_{2} \mathrm{O}$ & 0,98 & 3,50 & 5,40 & 11,60 & 8,40 & 4,30 & 5,60 & - \\
\hline & Dias com chuva & 5 & 11 & 7 & 13 & 17 & 16 & 13 & - \\
\hline & Temperatura $\left({ }^{\circ} \mathrm{C}\right)$ & 16,09 & 22,74 & 21,78 & 22,95 & 23,13 & 23,83 & 24,88 & - \\
\hline & $\mathrm{Aa}$ & 0,75 & 0,67 & 0,59 & 0,58 & 0,58 & 0,54 & 0,53 & - \\
\hline & $\mathrm{mmH}_{2} \mathrm{O}^{*}$ & 0,08 & 0,30 & 0,47 & 1,00 & 0,72 & 0,37 & 0,48 & - \\
\hline & Dias com chuva* & 0,29 & 0,65 & 0,41 & 0,76 & 1,00 & 0,94 & 0,76 & - \\
\hline & $\begin{array}{c}\text { Temperatura } \\
\left({ }^{\circ} \mathrm{C}\right)^{*}\end{array}$ & 0,65 & 0,91 & 0,88 & 0,92 & 0,93 & 0,96 & 1,00 & - \\
\hline & $\mathrm{Aa}^{*}$ & 1,00 & 0,89 & 0,78 & 0,77 & 0,77 & 0,72 & 0,71 & - \\
\hline \multirow{8}{*}{ Avaré } & $\mathrm{mmH}_{2} \mathrm{O}$ & - & 0,56 & 8,27 & 3,06 & 4,48 & 8,58 & 6,10 & 1,41 \\
\hline & Dias com chuva & - & 5 & 10 & 11 & 11 & 20 & 18 & 9 \\
\hline & Temperatura $\left({ }^{\circ} \mathrm{C}\right)$ & - & 20,45 & 20,56 & 21,52 & 23,82 & 22,48 & 24,58 & 22,58 \\
\hline & $\mathrm{Aa}$ & - & 0,62 & 0,58 & 0,58 & 0,56 & 0,55 & 0,56 & 0,54 \\
\hline & $\mathrm{mmH}_{2} \mathrm{O}^{*}$ & - & 0,07 & 0,96 & 0,36 & 0,52 & 1,00 & 0,71 & 0,16 \\
\hline & Dias com chuva* & - & 0,25 & 0,50 & 0,55 & 0,55 & 1,00 & 0,90 & 0,45 \\
\hline & $\begin{array}{c}\text { Temperatura } \\
\left({ }^{\circ} \mathrm{C}\right)^{*}\end{array}$ & - & 0,83 & 0,84 & 0,88 & 0,97 & 0,91 & 1,00 & 0,92 \\
\hline & $\mathrm{Aa}^{*}$ & - & 1,00 & 0,94 & 0,94 & 0,90 & 0,89 & 0,90 & 0,87 \\
\hline
\end{tabular}


Gráfico 18 - Relação entre a atividade de água e a contaminação por Fusarium spp. e Alternaria spp. nas amostras de Capão Bonito.

\section{Capão Bonito}

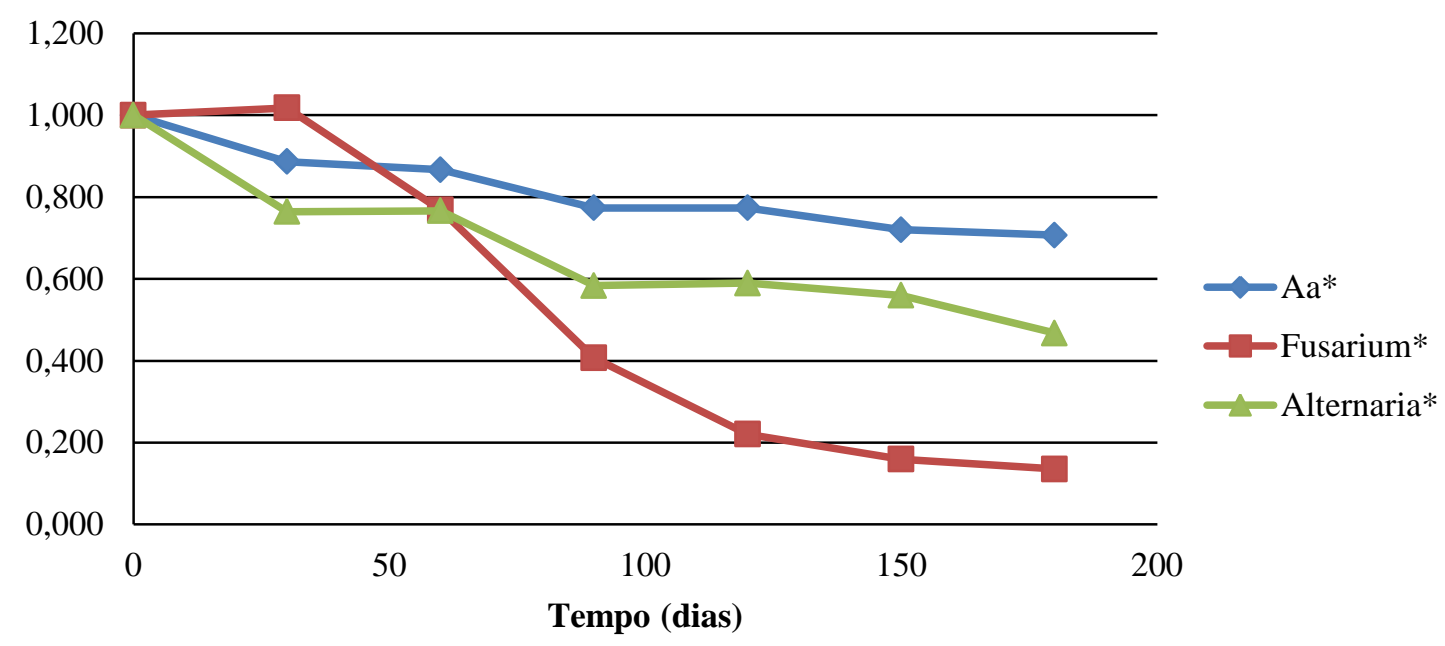

Gráfico 19 - Relação entre a atividade de água e a contaminação por Fusarium spp. e Alternaria spp. nas amostras de Avaré.

Avaré

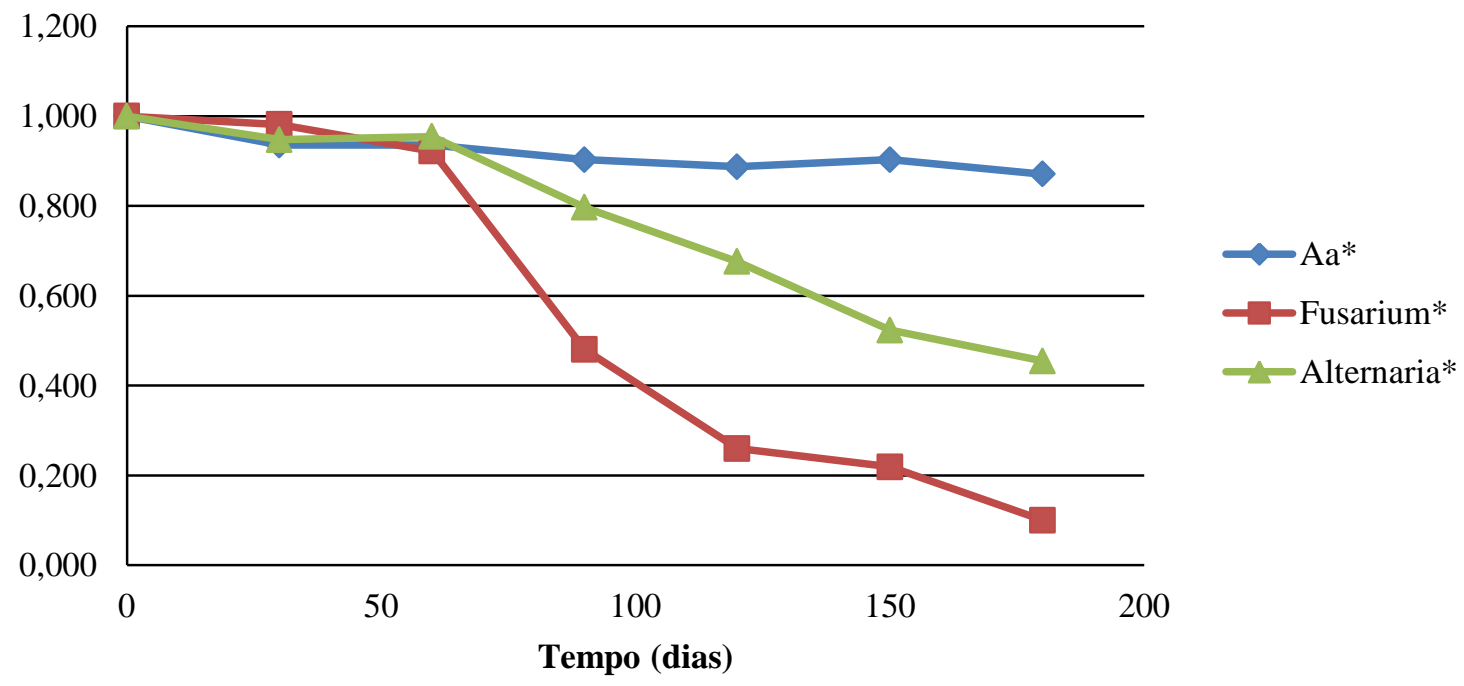


Gráfico 20 - Dados metereológicos normalizados da região de Capão Bonito.

\section{Capão Bonito}

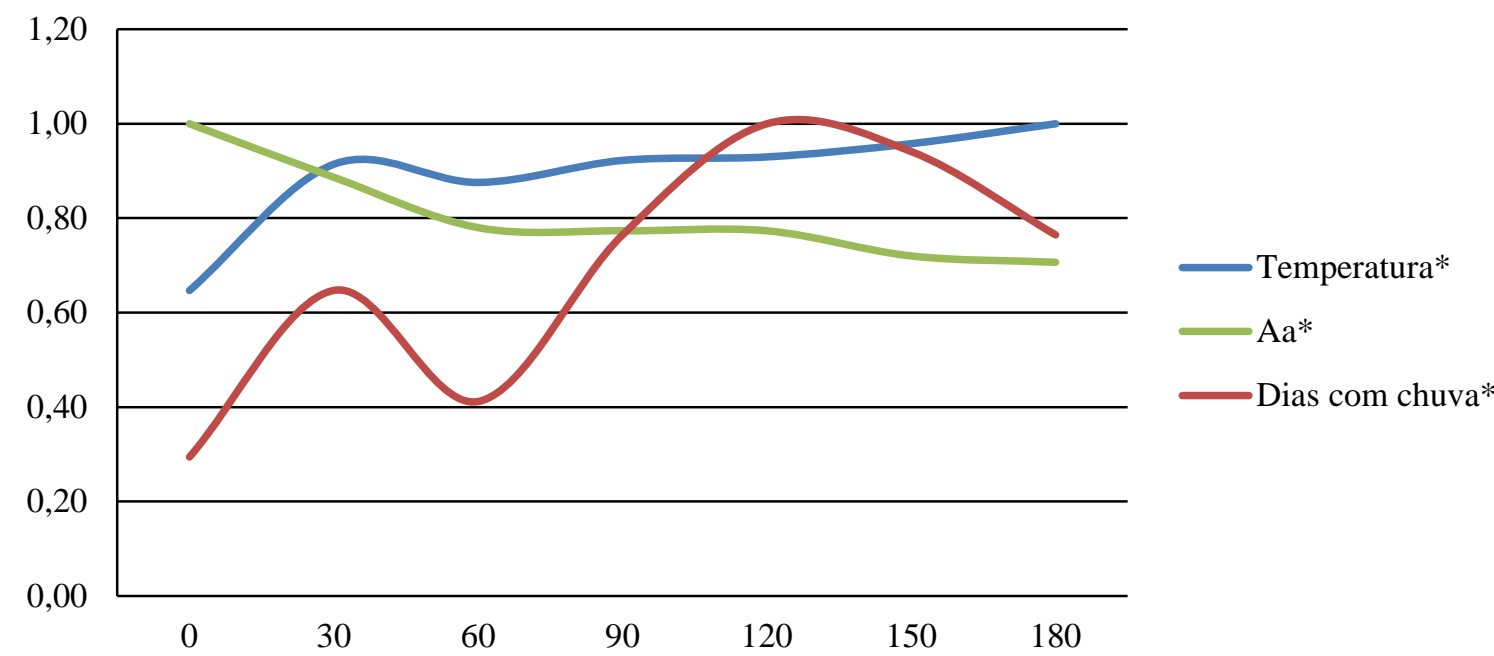

Gráfico 21 - Dados metereológicos normalizados da região de Avaré.

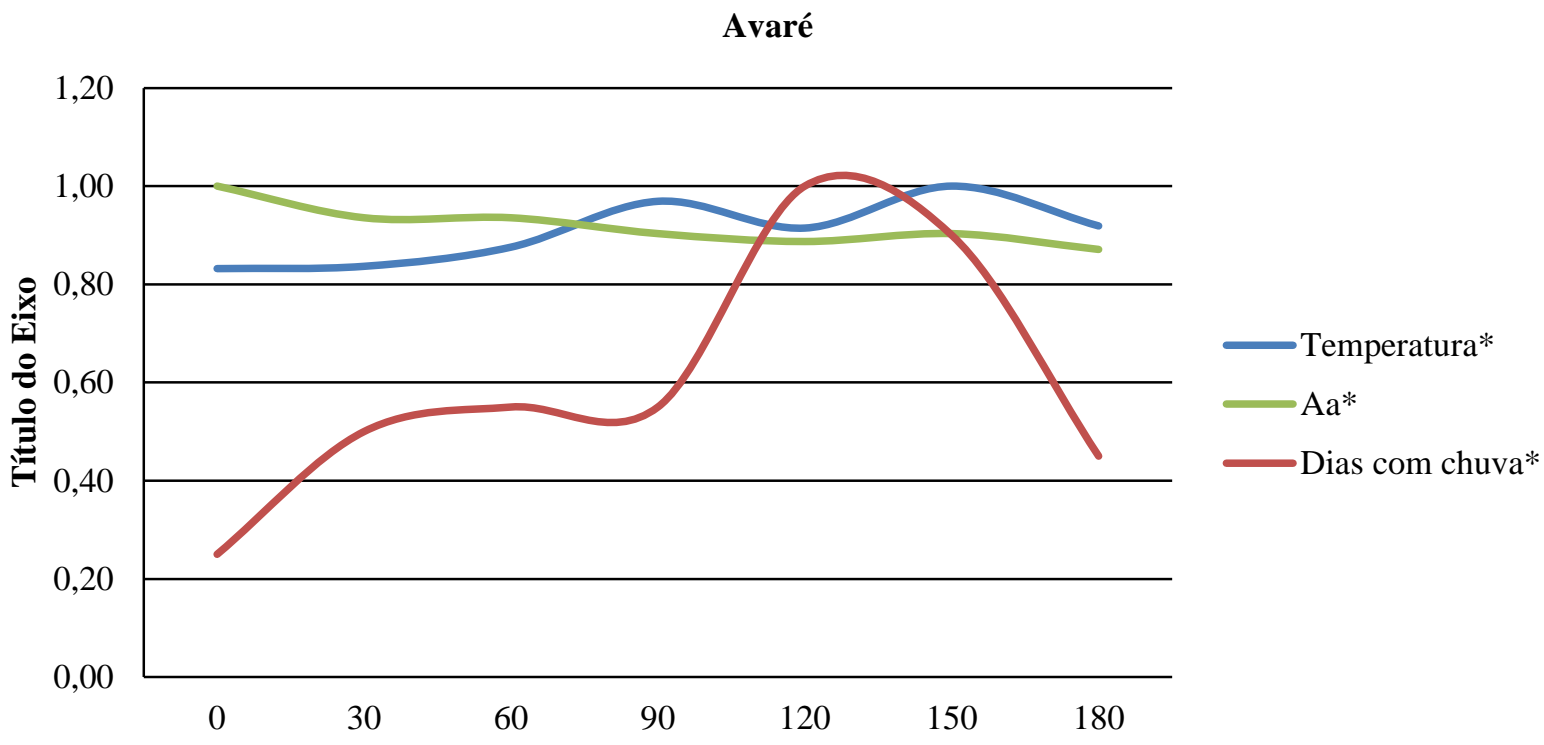




\subsection{ANÁLISE MICOTOXICOLÓGICA}

As análises micotoxicológicas foram acompanhadas de corrida de padrão e construção de curva analítica. A curva analítica é o método de quantificação mais frequentemente utilizado e consiste na determinação da resposta do instrumento às várias concentrações da substância em estudo (PRIMEL, 2003).

Valores iguais ou superiores a 0,99 e 0,90 são recomendados para o coeficiente de determinação da curva, respectivamente pela ANVISA (2003) e pelo INMETRO (2003). Os valores de $r^{2}$ obtidos nas curvas de DON $(0,9963)$, ZEA $(0,9994)$ e AOH $(0,9951)$ estão de acordo com o recomendado pelos órgãos (Anexo B).

Figura 147 - Cromatograma e espectro de padrões de DON e ZEA.

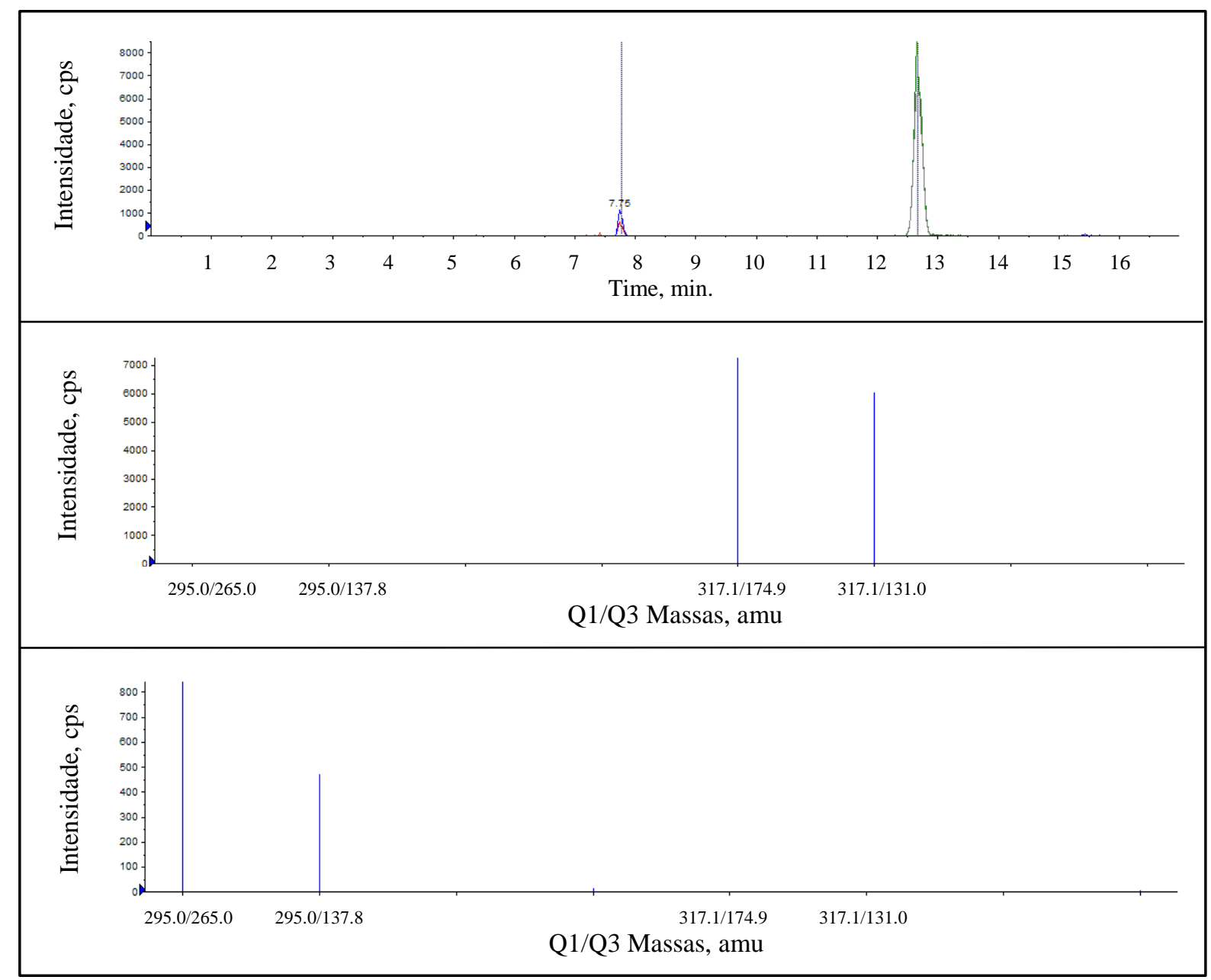


A Figura 17 mostra um dos espectros gerados relativo aos padrões de $10 \mathrm{ppb}$ de DON e 4 ppb de ZEA, na qual se pode confirmar o tempo de retenção das toxinas, de 7,5 min no caso de DON e 12,5 min no caso de ZEA, e a razão m/z dos íons filhos (265,0 e 137,8 para DON e 174,9 e 131,0 para ZEA) obtidos a partir dos íons precursores (295,0 para DON e 317,1 para ZEA).

O pico cromatográfico referente à eluição de $\mathrm{AOH}$ está demonstrados na Figura 18.

Figura 1815 - Pico cromatográfico referente à eluição do padrão de 40 ppb de AOH.

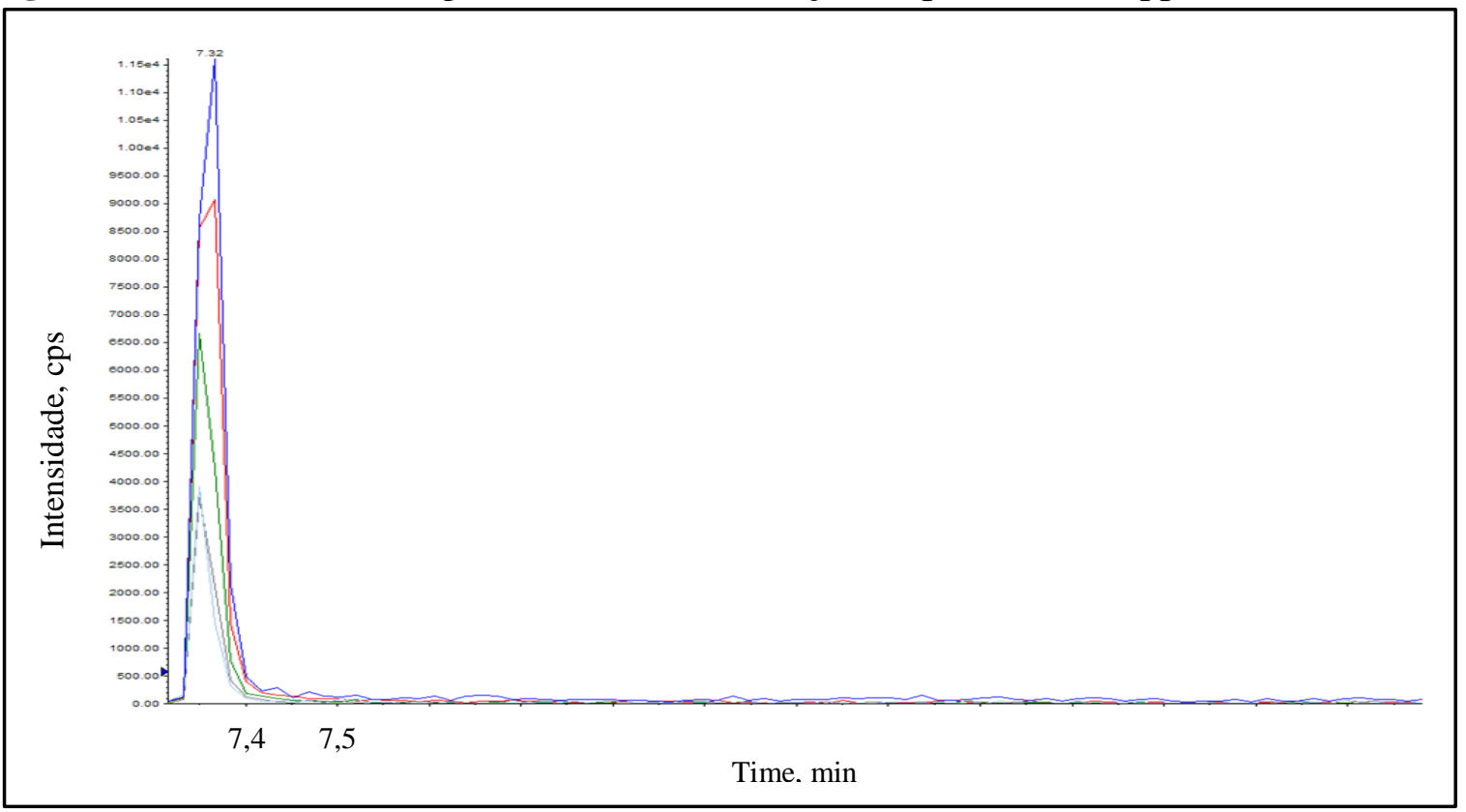

\subsubsection{Teste de Recuperação}

Para realização dos ensaios de recuperação, as amostras foram fortificadas conforme item 3.3.4.2.2. Os resultados foram avaliados conforme 2006/401/EC, em termos de porcentagem de recuperação através da Equação 2 e desvio padrão relativo (DPR) através da Equação 3.

A Tabela 9 apresenta os valores obtidos no teste de recuperação com o respectivo DPR, para os três níveis de fortificação preparadas para as três toxinas.

A diretriz 2006/401/EC fornece as recomendações específicas para performance de ensaios de recuperação de micotoxinas. Segundo esta diretriz, para ensaios de recuperação de DON em níveis de concentrações entre $100-500 \mu \mathrm{g} / \mathrm{kg}$ o valor recomendado para recuperação é de 60 - $110 \%$. Já para ensaios de recuperação de DON realizados em níveis de 
concentração maiores que $500 \mu \mathrm{g} / \mathrm{kg}$ o valor de recuperação recomendado é de $70-120 \%$. Quanto à ensaios de recuperação de ZEA, para níveis $\leq 50 \mu \mathrm{g} / \mathrm{kg}$, o valor recomendado para recuperação é de $60-120 \%$ e, quando > $50 \mu \mathrm{g} / \mathrm{kg}$, o intervalo é de $70-120 \%$.

O teste de recuperação indica o quanto um método é eficaz na extração, detecção e quantificação de analitos presentes em uma amostra desconhecida. Conforme indicado na Tabela 9, os níveis de recuperação obtidos estão de acordo com intervalos recomendados, demonstrando a exatidão do método para a detecção e quantificação das toxinas em grãos de trigo.

Não há recomendações quanto ao $\mathrm{AOH}$, mas pode-se observar que o teste de recuperação para esta toxina encontra-se dentro dos limites estabelecidos para as outras micotoxinas.

Tabela 9 - Valores obtidos para o ensaio de recuperação (\%) e DPR (\%).

\begin{tabular}{c|ccc}
\hline \multirow{2}{*}{ Analito } & Nível de Fortificação $(\boldsymbol{\mu g} / \mathbf{k g})$ & Recuperação $(\%)$ & DPR (\%) \\
\hline \multirow{2}{*}{ DON } & 200 & 97,71 & 17,91 \\
& 500 & 101,96 & 15,58 \\
& 1000 & 97,58 & 17,17 \\
ZEA & 20 & 96,43 & 12,54 \\
& 200 & 101,14 & 8,88 \\
& 600 & 86,88 & 44.93 \\
& 10 & 102,6 & 6,43 \\
\hline \multirow{2}{*}{ AOH } & 300 & 95,65 & 3,69 \\
\hline & 1000 & 111,1 & \\
\hline
\end{tabular}




\subsubsection{Limite de detecção e quantificação}

Na Tabela 10 encontram-se resumidos os valores obtidos para os limites de detecção e quantificação instrumentais (LODi e LOQi, respectivamente) e os limites de detecção e quantificação do método (LODm e LOQm, respectivamente).

Tabela 10 - Valores obtidos para os limites de detecção e quantificação em ppb.

\begin{tabular}{c|cccc}
\hline Analito & LODi & LOQi & LODm & LOQm \\
\hline DON & 0,25 & 1 & 50 & 200 \\
ZEA & 0,015 & 0,1 & 3 & 20 \\
AOH & 0,005 & 0,03 & 1 & 6 \\
\hline
\end{tabular}

A Figura 19 refere-se à amostra de maior contaminação encontrada, com $2910 \mu \mathrm{g} / \mathrm{kg}$ de DON.

Figura 1916 - Cromatograma e espectro de amostra com DON.

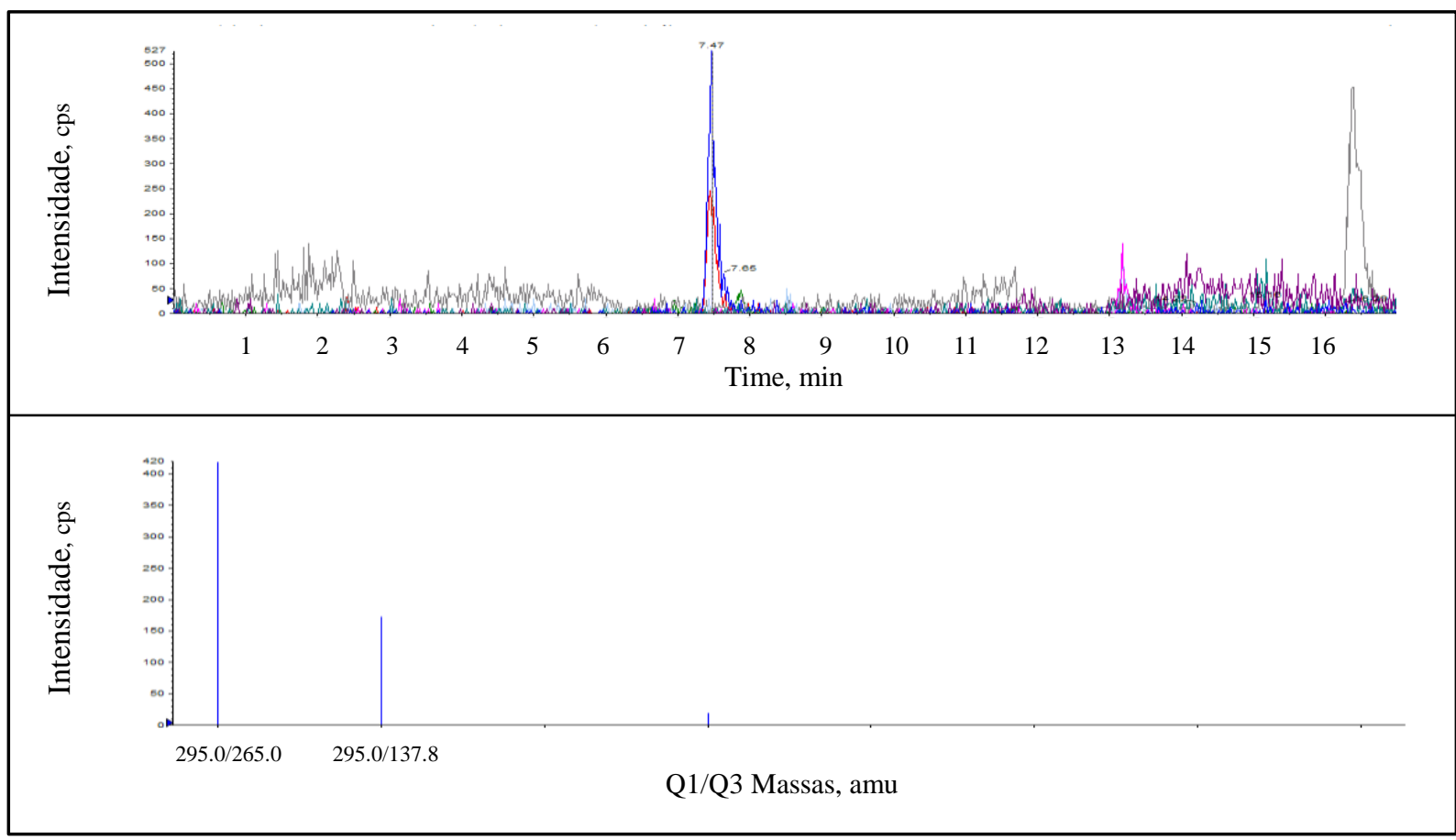


Tabela 11 - Deoxinivalenol em grãos de trigo recém-colhidos e armazenados na região de Capão Bonito.

\begin{tabular}{|c|c|c|c|c|c|c|}
\hline $\begin{array}{l}\text { Amostras de grãos de trigo } \\
\qquad \mathrm{n}=70\end{array}$ & \multicolumn{5}{|c|}{ Número de amostras dentro do intervalo de concentração de deoxinivalenol $(\mu \mathrm{g} / \mathrm{kg})$} & $\begin{array}{c}\text { Contaminação } \\
\text { média } \\
(\mu \mathrm{g} / \mathrm{kg})\end{array}$ \\
\hline $\begin{array}{l}\text { Recém-colhido } \\
\quad(\mathrm{n}=10)\end{array}$ & 0 & $\begin{array}{c}3 \\
(30 \%)\end{array}$ & $\begin{array}{c}6 \\
(60 \%)\end{array}$ & $\begin{array}{c}1 \\
(10 \%)\end{array}$ & 0 & 1255 \\
\hline $\begin{array}{l}1^{\circ} \text { Mês de Armazenamento } \\
\qquad(\mathrm{n}=10)\end{array}$ & 0 & $\begin{array}{c}2 \\
(20 \%)\end{array}$ & $\begin{array}{c}5 \\
(50 \%)\end{array}$ & $\begin{array}{c}3 \\
(30 \%)\end{array}$ & 0 & 1693 \\
\hline $\begin{array}{l}3^{\circ} \text { Mês de Armazenamento } \\
\qquad(\mathrm{n}=10)\end{array}$ & 0 & $\begin{array}{c}3 \\
(30 \%)\end{array}$ & $\begin{array}{c}6 \\
(60 \%)\end{array}$ & $\begin{array}{c}1 \\
(10 \%)\end{array}$ & 0 & 1319 \\
\hline $\begin{array}{l}4^{\circ} \text { Mês de Armazenamento } \\
\qquad(\mathrm{n}=10)\end{array}$ & 0 & $\begin{array}{c}9 \\
(90 \%)\end{array}$ & $\begin{array}{c}1 \\
(10 \%)\end{array}$ & 0 & 0 & 605 \\
\hline $\begin{array}{l}5^{\circ} \text { Mês de Armazenamento } \\
\qquad(\mathrm{n}=10)\end{array}$ & 0 & $\begin{array}{c}10 \\
(100 \%)\end{array}$ & 0 & 0 & 0 & 331 \\
\hline
\end{tabular}


$\mathrm{Na}$ presente investigação, os níveis de micotoxinas detectados nas amostras de trigo são sinalizadores do perfil dos grãos de trigo produzidos no Estado de São Paulo.

O procedimento de extração aliado à detecção pelo espectrômetro de massas permitiu redução no número de etapas de preparo de amostra, diminuindo possíveis erros associados às diferentes etapas do processo, redução do tempo de análise eredução do volume de solventes utilizados durante a análise.

Das 70 amostras da região de Capão Bonito, 69 (98,6\%) apresentaram contaminação por DON $(210$ - $2910 \mu \mathrm{g} / \mathrm{kg})$ e 3 amostras contaminação por ZEA $(20$ - 30,1 $\mu \mathrm{g} / \mathrm{kg})$. Os resultados obtidos durante as 7 coletas estão indicados na Tabela 11.

O nível de contaminação por DON foi inferior aos limites estabelecidos recentemente pela legislação brasileira $(3000 \mu \mathrm{g} / \mathrm{kg})$, porém os valores encontram-se próximo ao limiar permitido e superam os limites legais definidos pela Comunidade Européia (1750 $\mu \mathrm{g} / \mathrm{kg})$.

A presença de DON e ZEA em trigo e derivados também foi constatada por outros autores brasileiros que constataram, de modo geral, frequência e níveis de DON superiores aos níveis de ZEA (CALORI-DOMINGUES et al., 2007; FURLONG, 1992; FURLONG et al., 1995; OLIVEIRA et al., 2002).

A não detecção de $\mathrm{AOH}$ nas amostras, apesar da elevada frequência de isolamento de Alternaria spp., principalmente A. alternata, demonstra que a simples presença de fungos toxigênicos em alimentos não significa, necessariamente, que a micotoxina esteja presente no substrato; todavia há indicação de risco potencial de contaminação por micotoxinas. Tampouco a ausência de fungo exclui a presença de um metabólito tóxico. Este fato foi mencionado anteriormente por outros autores (PITT; HOCKING, 2009; OSBORNE, 1982).

Este é o primeiro estudo a abordar a ocorrência de AOH em trigo no Brasil. Apesar de não ter sido detectada sua presença nas amostras analisadas, a elevada contaminação pelo fungo produtor da toxina sugere a necessidade de monitoramento contínuo dos grãos.

As amostras de Avaré não apresentaram contaminação por nenhuma das micotoxinas, o que coincide com a menor contaminação fúngica verificada nas amostras dessa região, fato este que pode ser justificado pelo prévio processo de beneficiamento ao qual foram submetidas.

Praticamente todo o tipo de alimentos é susceptível de ser contaminado durante os processos de produção, processamento, transporte ou armazenagem (SANTIN, 2005) e o nível de contaminação por micotoxinas tem relação com a mercadoria, condições climáticas, práticas agrícolas, condições de armazenamento e as variações sazonais (WARTH et al., 2012). 
As colheitas podem estar contaminadas com várias micotoxinas, uma vez que a maioria dos fungos têm a capacidade de produzir mais de uma micotoxina (MELO DOS SANTOS; DORNER; CARREIRA, 2002), além da mistura de metabólitos que ocorre, quando se combinam diferentes matérias-primas para a formulação de alimentos compostos, o que torna a avaliação da exposição a micotoxinas ainda mais complexa (MIROCHA; CHRISTENSEN, 1974).

A contaminação fúngica e a produção de micotoxinas são altamente dependentes das condições climáticas e os resultados variam de ano para ano, e de região para região, conforme já observado por outros autores (CASA, 2004), tornando importante um monitoramento anual e regional de ambas, doenças e toxinas.

A micologia e micotoxicologia alimentar têm uma importância fundamental para a segurança alimentar e seu controle protege a saúde e bem-estar de animais e humanos, evita a perda de nutrientes essenciais, o aparecimento de características organolépticas indesejáveis, a produção de metabolitos tóxicos nos alimentos e permite ainda destruição de alimentos inadequados ao consumo.

Uma forma eficaz e barata de controlar o crescimento fúngico, é através da manipulação do microambiente onde os gêneros alimentícios são armazenados. Além disso, aplicar boas práticas agrícolas, como selecionar sementes não contaminadas, aplicar medidas de controle de insetos, roedores, entre outras (MALLMANN et al., 2006) são algumas alternativas, já que muitas micotoxinas se formam ainda durante o período de crescimento das plantas, no campo.

As principais medidas profiláticas consistem em adotar técnicas de cultivo e manejo que inviabilizem o crescimento fúngico, tais como: escolha de variedades mais resistentes; a escolha do momento ideal para a colheita, uma vez que as culturas tardias tendem a ter maiores probabilidades de serem contaminadas; minimização da exposição às intempéries e realização da secagem e estocagem em armazéns ou silos adequados para cada tipo de cereal ou subproduto (JORNAL COOPERCAMPOS, 2009).

Doenças fúngicas não implicam apenas em perdas quantitativas como em perdas na qualidade e segurança do produto final. A queda na qualidade do trigo tem consequência significativa no preço do produto, o que evidencia a necessidade do monitoramento de doenças emergentes e da avaliação precisa da ameaça existente. Apesar do progresso significativo nos estudos temos ainda que avaliar a possível transferência das toxinas para a farinha de trigo e derivados depois de moagem e processamento do alimento e as implicações na saúde associadas com estas doenças. 
A contaminação de grãos com micotoxinas cria um risco de segurança alimentar, representa uma séria ameaça para a indústria pecuária, e tem um impacto negativo na economia (WINDELS, 2000; WU, 2004).

Os resultados da micobiota e da análise micotoxicológica encontrados nas amostras, principalmente da região de Capão Bonito, demonstram a necessidade de maior controle e fiscalização dos alimentos, visando conhecer a extensão dessa contaminação e fornecer informações importantes, escassas em nosso país, para os diversos segmentos envolvidos com a produção, utilização e comercialização de trigo bem como para fiscalização e pesquisa, a fim de garantir ao consumidor final produtos de melhor qualidade.

\subsection{ANÁLISE ESTATÍSTICA}

O enfoque estatístico do trabalho foi direcionado apenas para a toxina DON, devido a não detecção AOH e ZEA nas amostras de trigo. Os dados obtidos pela análise estatística encontram-se nas Tabelas de C1 a C14 (Anexo C).

O estudo dos efeitos das variáveis no crescimento dos fungos (Fusarium spp. e Alternaria spp.) e na produção da toxina DON, foi realizado utilizando modelos da classe GAMLSS (RIGBY; STASINOPOULOS, 2005). A distribuição da variável resposta foi realizada utilizando-se gráficos de resíduos quantílicos (RIGBY; STASINOPOULOS, 2005). O crescimento dos fungos (Fusarium spp. e Alternaria spp.) e a produção de DON foram avaliados utilizando os modelos binomial e gama, respectivamente. As variáveis preditoras consideradas nos modelos para crescimento fúngico foram: meses de armazenamento, atividade de água, região, temperatura e precipitação. Para a produção de DON foi incluída a variável porcentagem de grãos contaminados por Fusarium spp. A região de estudo não foi incluída já que não foi observada produção de DON em Avaré. O nível de significância utilizado em todos os modelos foi de 5\%. Quando necessário, comparações múltiplas foram realizadas utilizando o método de Bonferroni (NETER et al., 1996).

Após o cálculo da correlação de Pearson, considerou-se os dados obtidos, empregando os meios DRBC e DG 18, independentes. Portanto, incluiu-se adicionalmente a variável meio de cultura nos modelos de crescimento fúngico. (NETERet al., 1996). 


\subsubsection{Análise do crescimento de Fusarium spp.}

Através das Tabelas C6 e C7 (Anexo C) notou-se que a proporção de grãos de trigo contaminada por Fusarium spp. variou em função dos meses de armazenamento ( $<<0,0001)$ e da região ( $p<0,0001)$. Porém, não houve indícios de variação em função da atividade de água $(\mathrm{p}=0,527)$, da precipitação $(\mathrm{p}=0,726)$, da temperatura $(\mathrm{p}=0,827)$ e do meio de cultura utilizado $(\mathrm{p}=0,531)$.

O efeito de cada variável, na proporção de grãos de trigo contaminado por Fusarium spp., pode ser constatado na Tabela C6 (Anexo C). Mantida a região constante, estima-se, por exemplo, que a proporção de grãos de trigo contaminada por Fusarium spp. após 6 meses de armazenamento, seja $89 \%((1-0,11)$ x 100\%) menor do que a observada no trigo recémcolhido. Mantido o tempo de armazenamento constante, estima-se ainda que a proporção de contaminação por Fusarium spp. seja $221 \%$ ((3,21 - 1) x 100\%) maior em Capão Bonito do que em Avaré.

A Tabela C8 (Anexo C) traz os resultados das comparações múltiplas entre os meses para a proporção de grãos de trigo que contaminados por Fusarium spp. Como o número total de comparações é 6,, são consideradas significantes as comparações com valor-p inferior a $0,0083(0,05 / 6)$. Pode-se concluir que a proporção de grãos de trigo contaminada por Fusarium spp. diminui com o aumento do tempo de armazenamento.

\subsubsection{Análise do crescimento de Alternaria spp.}

A partir das Tabelas C9 e C10 (Anexo C) notou-se que a proporção de grãos de trigo contaminados por Alternaria spp. variou em função da interação entre as variáveis meses de armazenamento e região $(\mathrm{p}=0,0029)$ e da interação entre as variáveis meio de cultura e região $(\mathrm{p}=0,0018)$. Porém, não houve indícios de que a contaminação por Alternaria spp. variou em função da atividade de água $(\mathrm{p}>0,982)$, da precipitação $(\mathrm{p}>0,31)$ e da temperatura $(\mathrm{p}>0,06)$.

Embora não tenha sido observada correlação estatística entre o crescimento fúngico e a atividade de água, a diminuição na freqüência de contaminação por Alternaria spp. e Fusarium spp. foi acompanhada de uma redução nos níveis de atividade de água.

A Tabela C11 (Anexo C) traz os resultados das comparações múltiplas da proporção de grãos de trigo contaminados por Alternaria spp. Como foi constatada interação entre as variáveis presentes no modelo, foi necessário fazer comparações entre os diferentes níveis de 
cada variável. Foram consideradas significantes as comparações com valor-p inferior ao valor apresentado na penúltima coluna da Tabela C11 (Anexo C). Como tendência geral, conclui-se que a proporção de grãos de trigo contaminada por Alternaria spp. diminuiu à medida que se aumenta o tempo de armazenamento tanto em Capão Bonito quanto em Avaré.

Comparando as duas regiões de estudo, pela Tabela C11 (Anexo C), notou-se que a contaminação por Alternaria spp., utilizando os dois meios de cultura, foi maior em Capão Bonito do que em Avaré na maioria das coletas.

\subsubsection{Análise da produção de DON}

Através das Tabelas C12 e C13 (Anexo C) constatou-se que a produção média de DON em Capão Bonito variou em função dos meses de armazenamento ( $\mathrm{p}<0,0001$ ). Porém, não houve indícios de variação em função da frequência de Fusarium spp. (p = 0,956), da atividade de água $(\mathrm{p}=0,627)$, da precipitação $(\mathrm{p}=0,644)$ e da temperatura $(\mathrm{p}=0,121)$.

$\mathrm{O}$ isolamento de fungos toxigênicos em alimentos não significa obrigatoriamente a presença de micotoxina no substrato. Por outro lado, a ausência de fungos em alimentos suspeitos não significa ausência de micotoxinas, uma vez que elas podem permanecer no produto mesmo após o desaparecimento do fungo (PITT e HOCKING, 2009; OSBORNE, 1982).

O efeito do período de armazenamento na produção de DON, em Capão Bonito, apresentado na Tabela C12 (Anexo C), revelou produção média 73,6\% ((1 - 0,264) x 100\%) menor após 5 meses de armazenamento, em relação à observada no trigo recém-colhido.

A Tabela C14 (Anexo C) traz os resultados das comparações múltiplas, entre os diferentes meses, para a produção média de DON em Capão Bonito. Foram consideradas significantes as comparações com valor-p inferior a $0,0083(0,05 / 6)$. Pode-se dizer que a produção média de DON diminuiu com o tempo de armazenamento, apesar do sexto mês ter apresentado um padrão diferente.

Em geral, a proporção de grãos de trigo contaminada por Fusarium spp. e Alternaria spp. e a produção de DON diminuíram com o aumento do tempo de armazenamento. Houve indícios de que a contaminação por Fusarium spp. e Alternaria spp. foi maior em Capão Bonito, comparativamente à registrada em Avaré. E não houve indícios de variação entre o crescimento de Fusarium spp. e Alternaria spp. e a produção de DON, em função da atividade de água, da temperatura e da precipitação. 


\section{CONCLUSÕES}

- A contaminação fúngica e micotoxicológica variaram em função da localização da região produtora e do tempo de armazenamento, porém, não constatou-se relação estatística com os fatores abióticos (atividade de água, temperatura e precipitação);

- A elevada prevalência de Alternaria nas amostras sinaliza a necessidade de mais pesquisas sobre a ocorrência de outras toxinas de Alternária em grãos de trigo devido à toxicidade das mesmas;

- Apesar da baixa detecção de ZEA e da ausência de contaminação por AOH nas amostras de trigo, a presença de fungos potencialmente produtores (Altenaria alternata e Fusarium graminearum) são sinalizadores da necessidade de pesquisas futuras sobre a ocorrência destas toxinas no produto;

- O método empregado para extração e purificação de amostras de grãos de trigo com detecção por espectrometriade massas sequencial e ionização por electrospray mostrou-se um método rápido, sensível e confiável para determinação de DON, ZEA e $\mathrm{AOH}$;

- Os níveis de contaminação por DON detectados nas amostras de grãos de trigo estão abaixo dos limites estabelecidos pela legislação brasileira (3000 ppb) e acima dos exigidos pela legislação européia (1750 ppb);

- É prudente que se realize um monitoramento contínuo de grãos de trigo para contaminação micológica e micotoxicológica, permitindo avaliar a exposição dos consumidores e animais a estas contaminações e estabelecer uma série de diretrizes de segurança alimentar regional. 


\section{REFERÊNCIAS*}

AGÊNCIA NACIONAL DE VIGILÂNCIA SANITÁRIA (ANVISA). Resolução - RDC nº 7 , de 07 de Fevereiro de 2011. Disponível em: < http://portal.anvisa.gov.br/wps/content/anvisa+portal/anvisa/sala+de+imprensa/menu++noticias+anos/2011+noticias/anvisa+estabelece+limites+para+presenca+de+micotoxinas+e m+alimentos > Acesso em: 03 jun. 2011.

AGÊNCIA NACIONAL DE VIGILÂNCIA SANITÁRIA (ANVISA). Resolução - RDC N ${ }^{\circ}$ 344, de 13 de Dezembro de 2002. Regulamento técnico para a fortificação das farinhas de trigo e das farinhas de milho com ferro e ácido fólico. Disponível em: <http://portal.anvisa.gov.br/wps/wcm/connect/f851a500474580668c83dc3fbc4c6735/RDC_3 44_2002.pdf?MOD=AJPERES> Acesso em: 03 ago. 2011.

AGÊNCIA NACIONAL DE VIGILÂNCIA SANITÁRIA (ANVISA). Resolução RE 899, de 29 de maio de 2003. Guia para a validação de métodos analíticos e bioanalíticos. Diário Oficial da União, Brasília, DF, 02 jun. 2003.

AGILENT TECHNOLOGIES. Basics of LC/MS. New York, 2001. 36 p.

AGRONET.

Disponível

em: <http://www.cenargen.embrapa.br/publica/trabalhos/am2003/arquivos/26080302.pdf > Acesso em: 21 set. 2013.

ALMEIDA, A. P.; FONSECA, H.; FANCELLI, A. L.; DIREITO, G. M.; ORTEGA, E. M.; CORREAA, B. Myclofora and fumonisin contamination in Brazilian corn from sowing to harvest. Journal of Agricultural and Food Chemistry, v. 50, p. 3877-3882, 2002.

ALMEIDA, R. R. Ocorrência de Fusarium graminearum e desoxinivalenol em grãos de trigo utilizados no Brasil. 2006. 58 f. Dissertação (Mestrado em Ciências) - Ciências e Tecnologia de Alimentos, Escola Superior de Agricultura "Luiz de Queiroz", Universidade de São Paulo, Piracicaba. 2006.

ALVAREZ, C. L.; SOMMA, S.; PROCTOR, R. H.; STEA, G.; MULÈ, G.; LOGRIECO, A. F.; PINTO, V. F.; MORETTI, A. Genetic Diversity in Fusarium graminearum from a Major Wheat-Producing Region of Argentina. Toxins, v. 3, p. 1294-1309, 2011.

AMERICAN PHYTOPATHOLOGICAL SOCIETY (APSnet). Disponível em: <http://www.apsnet.org> Acesso em: 12 jun. 2012.

ANDERSEN, B.; DONGO, A.; PRYOR, B. M. Secondary metabolite profiling of Alternaria dauci, A. porri, A. solani, and A. tomatophila. Mycological Research, v. 112, p. 241-250, 2008.

\footnotetext{
*De acordo com:

ASSOCIAÇÃO BRASILEIRA DE NORMAS TÉCNICAS. NBR 6023: informação e documentação: referências: elaboração. Rio de Janeiro, 2002.
} 
ANDERSEN, B.; KROGER, E.; ROBERTS, R. G. Chemical and morphological segregation of Alternaria alternata, A. gaisen, and A. longipes. Mycological Research, v. 105, p. 291-299, 2001.

ANDERSEN, B.; KROGER, E.; ROBERTS, R. G. Chemical and morphological segregation of Alternaria arborescens, A. infectoria, and A. tenuissima species-groups. Mycological Research, v. 106, p. 170-182, 2002.

ANDERSEN, B.; SORENSEN, J. L.; NIELSEN, K. F.; VAN DEN ENDE, B. G.; DE HOOG, S. A polyphasic approach to the taxonomy of the Alternaria infectoria speciesegroup. Fungal Genetics and Biology, v. 46, p. 642-656, 2009.

ANGELOTTI, F.; TESSMANN, D. J.; ALVES, T. C. A.; VIDA, J. B.; FILHO, D. S. J.; HARAKAVA, R. Caracterização morfológica e identificação molecular de isolados de Fusarium graminearum associados à giberela do trigo e triticale no sul do Brasil. Summa Phytopathologica v. 32, p. 177-179, 2006.

APPLIED BIOSYSTEMS. Operator`s Manual. 2005. 266 p.

ASSOCIAÇÃO BRASILEIRA DA INDÚSTRIA DO TRIGO (ABITRIGO). Disponível em: <http://www.abitrigo.com.br/index.php?mpg=02.00.00> Acesso em: 05 maio 2011.

ASTOLFI, P.; dos SANTOS, J.; SCHNEIDER, L.; GOMES, L. B.; SILVA, C. N.; TESSMANN, D. J.; DEL PONTE, E. M. Molecular survey of trichothecene genotypes of Fusarium graminearum species complex from barley in Southern Brazil. International Journal of Food Microbiology, v. 148, p. 197-201, 2011.

ASTOLFI, P.; REYNOSOB, M. M.; RAMIREZB, M. L.; CHULZEB, S. N.; ALVESC, T. C. A.; TESSMANNC, D. J.; DEL PONTE, E. M. Genetic population structure and trichothecene genotypes of Fusarium graminearum isolated from wheat in southern Brazil. Plant Pathology, v. 61, p. 289-295, 2012.

AZCARATE, M. P.; PATRIARCA, A.; TERMINIELLO, L.; PINTO, V. F. Alternaria toxins in wheat during the 2004 to 2005 Argentinean harvest. Journal of Food Protection, v. 71, p. $1262-1265,2008$.

AYALEW, A.; FEHRMANN, H.; LEPSCHY, J.; BECK, R.; ABATE, D. Natural occurrence of mycotoxins in staple cereals from Ethiopia. Mycopathologia, v. 162, p. 57-63, 2006.

BARKAI-GOLAN, R.; PASTER, N. Mycotoxins in fruits and vegetable. Disponível em: $<$ http://books.google.com.br/books?id=ySRh-

nWkHl4C\&pg=PR8\&lpg=PR8\&dq=A.+citri,+A.+solani+e+A.+longipes\&source $=$ bl\&ots $=x I$ P4o7-SJR\&sig=6nJGxhzTerdvLTLmezTwxPxe48Q\&hl=pt-

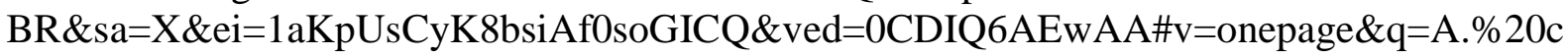
itri\%2C\%20A.\%20solani\%20e\%20A.\%20longipes\&f=false> Acesso em: 12 jun. 2013.

BEARDALL, J. M; MILLER, J. D. Diseases in humans with mycotoxins as possible causes. In: MILLER, J. D.; TRENHOLM, H. L. Mycotoxins in grain: compounds other than Aflatoxin. St. Paul, Minnesota, US: Eagan Press. 1994. p. 487-539. 
BECHTEL, D. B.; KALEIKAU, L. A.; GAINES, R. L.; SEITZ, L. M. The effects of Fusarium graminearum infection on wheat kernels. Cereal Chemistry, Saint Paul, v. 62, n. 2, p. 191-197, 1985.

BENSASSI, F.; ZID, M.; RHOUMA, A.; BACHA, H.; HAJLAOUI, M. R. First report of Alternaria species associated with black point of wheat in Tunisia. Annals of Microbiology, v.59, n. 3, p. 465-467, 2009.

BERJAK, P. Report of seed storage committe working group on the effects of storage fungi on seed viability. 1980-1983. Seed Science and Technology, v. 12, p. 233-253, 1984.

BIRZELE, B.; PRANGE, A.; KRAMER, J. Deoxynivalenol and ochratoxin A in german wheat and changes of level in relation to storage parameters. Food Additives and Contaminants, v. 17, p. 1027-1035, 2000.

BOTTALICO, A.; LOGRIECO, A. Toxigenic Alternaria species of economic importance. In: SINHA, K. K.; BHATNAGAR, D. (Ed.). Mycotoxins in agriculture and food safety. New York, NY, USA: Marcel Dekker, Inc., 1998. p. 65-108.

BOTTALICO, A.; PERRONE, G. Toxigenic Fusarium associated with head blight in smallgrain cereals in Europe. European Journal of Plant Pathology, Dordrecht, v. 108, p. 611-624, 2002.

BOUTIGNY, A. L.; WARD, T. J.; COLLER, G. J. V.; FLETT, B.; LAMPRECHT, S. C.; O'DONNELL, K.; VILJOEN, A. Analysis of the Fusarium graminearum species complex from wheat, barley and maize in South Africa provides evidence of species-specific differences in host preference. Fungal Genetics and Biology, v. 48, p. 914-920, 2011.

BRANCÃO, M. F.; DEL PONTE, E. M.; FARIAS, C. F. J.; BERNARDI, N. L.; ROSSETTO, E. A. Qualidade sanitária de sementes de trigo (Triticum Aestivum 1.) no estado do Rio Grande do Sul: safras 2004 e 2005. Revista Brasileira de Agrociência, v. 14, n. 2, p. 265-271, 2008.

BRASIL. Ministério da Agricultura, Pecuária e Abastecimento. Empresa Brasileira de Pesquisa Agropecuária. Cultura: trigo. Disponível em: <http://www.cnpt.embrapa.br/culturas/trigo/index.htm> Acesso em: 25 jun. 2011a.

BRASIL. Ministério da Agricultura, Pecuária e Abastecimento. Empresa Brasileira de Pesquisa Agropecuária. Vegetal: trigo. Disponível em: <http://www.agricultura.gov.br/vegetal/culturas/trigo> Acesso em: 28 jun. 2011b.

BRASIL. Ministério da Agricultura. Pecuária e Abastecimento. Empresa Brasileira de Pesquisa Agropecuária. Disponível em:<http://sistemasdeproducao.cnptia.embrapa.br/FontesHTML/Trigo/CultivodeTrigo/zonea mento.htm> Acesso em: 05 maio 2011c.

BRASIL. Ministério da Agricultura. Pecuária e Abastecimento. Empresa Brasileira de Pesquisa Agropecuária. Embrapa Trigo. Disponível em: <http://www.cnpt.embrapa.br/aunidade/histori.htm> Acesso em: 05 maio $2011 \mathrm{~d}$. 
BRASIL. Ministério da Agricultura. Pecuária e Abastecimento. Empresa Brasileira de Pesquisa Agropecuária. Embrapa Soja. Disponível em: <http://www.cnpso.embrapa.br/index.php?cod_pai=6\&op_page=91> Acesso em: 10 maio 2011e.

BRASIL. Ministério da Agricultura. Pecuária e Abastecimento. Empresa Brasileira de Pesquisa Agropecuária. Cultivo de Trigo. Doenças e métodos de controle. Disponível em: < http://sistemasdeproducao.cnptia.embrapa.br/FontesHTML/Trigo/CultivodeTrigo/doencas.ht m> Acesso em: 10 maio 2011f.

BRASIL. Ministério da Agricultura, Pecuária e Abastecimento. Empresa Brasileira de Pesquisa Agropecuária. Cultura: Arroz e Feijão. Disponível em: < http://sistemasdeproducao.cnptia.embrapa.br/FontesHTML/Feijao/FeijaoIrrigadoNoroesteMG /pos_colheita.htm> Acesso em 02 jun. 2012b.

BRASIL. Ministério da Agricultura. Pecuária e Abastecimento. Empresa Brasileira de Pesquisa Agropecuária. Trigo. Documentos Online. Disponível em: <http://www.cnpt.embrapa.br/biblio/do/p_do40_3.htm> Acesso em: 02 mar. $2013 \mathrm{a}$.

BRASIL. Ministério da Agricultura. Pecuária e Abastecimento. Empresa Brasileira de Pesquisa Agropecuária. Trigo. Disponível em: http://www.cnpt.embrapa.br/biblio/do/p_do74_1.htm> Acesso em: 02 nov. 2013b.

BRASIL. Ministério da Agricultura. Pecuária e Abastecimento. Empresa Brasileira de Pesquisa Agropecuária. Trigo. $\quad$ Disponível em: http://www.cnpt.embrapa.br/biblio/do/p_do126_2.htm> Acesso em: 02 nov. 2013c.

BRENN-STRUCKHOFOVA, Z; FÜREDER, C.; CICHNA-MARKL, M.; RAZZAZIFAZELI, E. Co-isolation of deoxynivalenol and zearalenone with sol-gel immunoaffinity columns for their determination in wheat and wheat products. Journal of Chromatography A, v. 1216, p. 5828-5837, 2009.

BRUGGER, E.M.; WAGNER, J.; SCHUMACHER, D.M.; KOCH, K.; PODLECH, J.; METZLER, M.; LEHMANN, L. Mutagenicity of the mycotoxin alternariol in cultured mammalian cells. Toxicology Letters, v. 164, p. 221-230, 2006.

BUSHUK, W. Wheat: chemistry and uses. Cereal Foods World, v. 31, n. 3, p. 218-226, 1986.

CALORI-DOMINGUES M. A.; ALMEIDA R. R.; TOMIWAKA M. M.; GALLO C. R.; GLORIA E. M.; DIAS C. T. S. Occurrence of deoxynivalenol in national and imported wheat used in Brazil. Ciência e Tecnologia dos Alimentos, Campinas, v. 27, n. 1, p. 181-185, 2007.

CARERI, M.; BIANCHI, F.; CORRADINI, C. Recent advances in the application of mass spectrometry in food-related analysis. Journal of Chromatoraphy A, v. 970, p. 3-64, 2002.

CARLILE, M. J.; WATKINSON, S. C. The Fungi. Londres: Academic Press, 1994. 180 p.

CARVALHO, N. M.; NAKAGAWA, J. Sementes: ciência, tecnologia e produção. 3. ed. Campinas: Fundação Cargill, 1988. 424 p. 
CASA, R. T.; REIS, E. M.; BLUM, M. M. C.; BOGO, A.; SCHEER, O.; ZANATA, T. Danos causados pela infecção de Giberella zeae em trigo. Fitopatologia Brasileira, v. 29, n. 3, p. 289-293, 2004.

CHOU, H.; WU, W. Phylogenetic analysis of internal transcribed spacer regions of the genus Alternaria, and the significance of filament-beaked conidia. Mycological Research, v. 106, p. 164-169, 2002.

CHRISTENSEN, C. M.; SAUER, D. B. Mycoflora. In: CHRISTENSEN, C. M. (Ed.). Storage of cereal grains and their products. Minnesota: American Association of Cereal Chemists, 1982. p. 219-40.

CHRISTENSEN, K. B.; VAN KLINK, J.W.; WEAVERS, R. T.; LARSEN,T. O.; ANDERSEN, B.; PHIPPS, R. K. Novel chemotaxonomic markers for the Alternaria infectoria speciesegroup. Journal of Agricultural and Food Chemistry, v. 53, p. 9431-9435, 2005.

CHU, F. S. Mycotoxins: food contamination mechanism, carcinogenic potential and preventive measures. Mutation Research, v. 259, p. 291-306, 1991.

CHULZE, S. N.; TORRES, A. M.; DALCERO, A. M.; ETCHEVERRY, M. G.; RAMÍREZ, M. L.; FARNOCHI, M. C. Alternaria Mycotoxins in Sunflower Seeds: Incidence and Distribution of the Toxins in Oil and Meal. Journal of Food Protection, v. 10, p. 1059-1064, 1995.

CIEGLER, A. Fungi that produce mycotoxins: conditions and occurrence. Mycopathologia, v. 65 , n. 5, p. 11, 1978.

COMPANHIA NACIONAL DE ABASTECIMENTO (CONAB). Levantamentos de Safra. Disponível em: <http://www.conab.gov.br/OlalaCMS/uploads/arquivos/13_07_09_09_04_53_boletim_graos_ junho__2013.pdf> Acesso em: 10 jul. 2013a.

COMPANHIA NACIONAL DE ABASTECIMENTO (CONAB). Mercado de trigo. Disponível em: <http://www.agricultura.gov.br/arq_editor/file/camaras_setoriais/Culturas_de_inverno/38RO/ App_Mercado_Inverno.pdf > Acesso em: 23 ago. 2013b.

COMPANHIA NACIONAL DE ABASTECIMENTO (CONAB). Acompanhamento da Safra Brasileira. Disponível em: <http://www.conab.gov.br/OlalaCMS/uploads/arquivos/13_08_09_10_43_44_boletim_portug es_agosto_2013_port.pdf> Acesso em: 15 set. 2013c.

COPPOCK, R. W.; CHRISTIAN, R. G. Aflatoxins. In: GUPTA, R. C. (Ed.). Veterinary toxicology: basic and clinical principles. New York: Elsevier, Academic Press, 2007. p. 939950.

CORRÊA, B. Microbiota fúngica. In: SCUSSEL, L. M. et al. Atualidades em micotoxinas e armazenagem de grãos. Florianópolis: Vildes Maria Scussel, 2000. p. 163-176. 
COUNCIL FOR AGRICULTURAL SCIENCE AND TECHNOLOGY (CAST). Task force report. Mycotoxins: risks in plant, animal and human systems. Council for Agricultural Science and Technology Ames. Iowa, 2003. p. 1999.

CROTTI, A. E. M. Espectrometria de massas com ionização por "electrospray": processos químicos envolvidos na formação de íons de substancias orgânicas de baixo peso molecular. Química Nova, v. 29, p. 287-292, 2006.

CRUZ, M. L. F.; MANSILLA, M. L.; TADEO, J. L. Mycotoxins in fruits and their processed products: analysis, occurrence and health implications. Journal of Advanced Research, v. 1, p. 113-122, 2010.

DAMBRÓS, F. P. Desenvolvimento e validação de metodologia analítica para a determinação de Micotoxinas em vinhos. 2013. 80 f. Dissertação (Mestrado em Ciência e Tecnologia dos Alimentos) - Centro de Ciências Rurais, Universidade Federal de Santa Maria, Santa Maria, 2013.

DESJARDINS, A. E. Fusarium mycotoxins: chemistry, genetics, and biology. APS Press, St. Paul, MN, USA, 2006, 260 p.

DIEKMANN, M.; PUTTER, C. A. J. Small grain temperate cereals. Roma: FAO/IPGRI, 1995. $67 \mathrm{p}$.

D’MELLO, J. P. F.; PLACINTA, C. M.; MACDONALD, A. M. C. Fusarium mycotoxins: a review of global implications for animal health, welfare and productivity. Animal Feed Science and Technology, v. 80, p. 183, 1999.

DOMSCH, K. H.; GAMS, W.; ANDERSON, T. H. Compendium of Soil Fungi. London: Academic Press, 1980. v. 2, p. 390.

DONG, Z. G.; LIU, G. T.; DONG, Z. M.; QIAN, Y. Z.; AN, Y. H.; MIAO, J. A.; ZHEN, Y. Z. Induction of mutagenesis and transformation by the extract of Alternaria alternata isolated from grains in Linxian, China. Carcinogenesis, v. 8, p. 989-991, 1987.

DOOHAN, F. M.; BRENNAN, J.; COOKE, B. M. Influence of climatic factors on Fusarium species pathogenic to cereals. European Journal of Plant Pathology, v. 109, p. 755-768, 2003.

ETZEL, R. Mycotoxins. Journal American Medical Association, v. 287, p. 425-427, 2002.

EUROPEAN COMMISION (EC). Commision Regulation $\mathrm{N}^{\circ} 401 / 200623$ de fevereiro de 2006. Laying down the methods of sampling and analysis for the official control of the levels of mycotoxins in foodstuffs. Official Journal of the European, 2006, L 70/12.

EUROPEAN COMMISION (EC). Commision Regulation $N^{\circ} 1126 / 200728$ de Setembro de 2007 que altera a Regulation (EC) $\mathrm{N}^{\circ}$ 1881/2006 setting maximum levels for certain contaminants in foodstuffs as regards Fusarium toxins in maize and maize products. Official Journal of European Union 2007, L255, 14.

FEHR, M.; PAHLKE, G.; FRITZ, J.; CHRISTENSEN, M. O.; BOEGE, F.; ALTEMÖLLER, M.; PODLECH, J.; MARKO, D. Alternariol acts as a topoisomerase poison, preferentially 
affecting the IIalpha isoform. Molecular Nutrition \& Food Research, v. 53, n. 4, p. 441-451, 2009.

FEINBERG, B.; MACLAUGHLIN, C. S. Biochemical mechanism of action of trichothecene mycotoxins. In: BEASLEY, V. R. (Ed.). Trichothecene Mycotoxins: pathophysiological effects. Boca Raton, FL: CRC Press, 1989. v. 1. p. 27-36.

FINK-GREMMELS, J.; MALEKINEJAD, H. Clinical effects and biochemical mechanisms associated with exposure to the mycoestrogen zearalenone. Animal Feed Science and Technology, v. 137, p. 326-341, 2007.

FONSECA, H. Sistema de amostragem para análise de aflatoxinas em grãos. Revista de Microbiologia, v. 21, p. 66-77, 1991.

FORCELINI, C. A.; REIS, E. M. Doença da cevada (Hordeum vulgare L.). In: KIMATI, H.; AMORIM, L.; BERGAMIN FILHO, A.; CAMARGO, L. E. A.; REZENDE, J. A. M. (Ed.). Manual de fitopatologia: doenças das plantas cultivadas. 3rd ed. São Paulo, SP: Agronômica Ceres, 1997. v. 2. p. 251-256.

FURLONG, E. B.; SOARES, L. M. V.; LASCA, C. C.; KOHARA, E. Y. Mycotoxins and fungi in wheat harvested during 1990 in test plots in the state of São Paulo, Brazil. Mycopathologia, v. 131, p. 185-190, 1995.

FURLONG, E. B. Tricoteceno em trigo: um estudo de metodologia analítica, incidência, contaminação simultânea por outras micotoxinas e de alguns fatores que influem na produção no campo. 1992. 120 p. Tese (Doutorado em Ciência de Alimentos) - Faculdade de Engenharia de Alimentos, Universidade Estadual de Campinas, 1992.

GAGKAEVA, T. Y.; YLI-MATTILA, T. Genetic diversity of Fusarium graminearum in Europe and Asia. European Journal of Plant Pathology, v. 110, p. 551-562, 2004.

GEISER, D. M.; JIMENEZ-GASCO, M.; KANG, S.; MAKALOWSKA, N.; VEERARAGHAVAN, T. J.; WARD, N.; ZHANG, G. A.; KULDAU, G.A.; O`DONNELL, K. FUSARIUM-ID v.1.0: A DNA sequence database for identifying Fusarium. European Journal of Plant Pathology, v. 110, p. 473-479, 2004.

GIMENO, A. O impacto negativo de algumas micotoxinas nas vacas leiteiras. Revista de Veterinária Albeitar de Portugal, v. 4, n. 5, p. 42-52, 2010.

GIRYN, H.; SZTEKE, B. Determination of Alternaria mycotoxins in selected raw and processed fruit and vegetable products. Roczniki Państwowego Zakładu Higieny, v. 46, p. 129-133, 1995.

GONZÁLEZ-OSNAYA, L.; FARRÉSA, A. Deoxynivalenol and zearalenone in Fusariumcontaminated wheat in Mexico City. Food Additives and Contaminants: Part B, v. 4, n. 1, p. 71-78, 2011.

GOSWAMI, R. S.; KISTLER, H. C. Pathogenicity and in planta mycotoxin accumulation among members of the Fusarium graminearum species complex on wheat and rice. Phytopathology, v. 95, n. 12, p. 1397-1401, 2005. 
GRABARKIEWICZ-SZCZENA， J.; CHELKOWSKI, J.; ZAJKOWSKI, P. Natural occurrence of Alternaria mycotoxins in the grain and chaff of cereals. Mycotoxin Research, $\mathrm{v}$. 5, p. 77-80, 1989.

GRANDE, S. M. B.; NETO, F. R. A. A espectrometria de massas acoplada a espectrometria de massas EM-EM. Química Nova, v. 13, 1990.

GRECO, M.; PATRIARCA, A.; TERMINIELLO, L.; PINTO, V. F.; POSE, G. Toxigenic Alternaria species from Argentinean blueberries. International Journal of Food Microbiology, v. 154, p. 187-191, 2012.

HAGLER, W. M.; TOWERS, N. R.; MIROCHA, C. J.; EPPLEY, R. M.; BRYDEN, W. L. Zearalenone: mycotoxin or mycoestrogen. In: FUSARIUM PAUL E. NELSON MEMORIAL SYMPOSIUM, 2001, St. Paul. Anais... St. Paul, MN: APS Press, 2001. p. 321-331.

HASIJA, S. K. Physiological studies of Alternaria citri and A. tenuis. Mycologia, v. 62, p. 289-295, 1970.

HILL, R. A.; LACEY, J. The microflora of ripening barley grain and the effects of pre harvest fungicide application. Annals of Applied Biology, v. 102, p. 455-465, 1983.

HOCKING, A. D. Fungal spoilage of high-fat foods. Food Australia, v. 46, p. 30-33, 1994.

HOCKING, A. D.; FAEDO, M. Fungi causing thread mould spoilage of vacuum packaged Cheddar cheese during maturation. International Journal of Food Microbiology, v. 16, p. 123-130, 1992.

HOMDORK, S.; FEHRMANN, H.; BECK, R. Influence of different storage conditions on the mycotoxin production and quality of Fusarium-infected wheat grain. Journal of Phytopathology, v. 148, p. 7-15, 2000.

HONG, S. G.; CRAMER, R. A.; LAWRENCE, C. B.; PRYOR, B. M. Alt a 1 allergen homologs from Alternaria and related taxa: analysis of phylogenetic content and secondary structure. Fungal Genetics and Biology, v. 42, p. 119-129, 2005.

HOSENEY, R. C. Principles of cereal science and technology. Saint Paul: American Association of Cereal Chemists, 1986. 327 p.

HUGHES, D. M.; GAHL, M. J.; GRAHAM, C. H.; GRIEB, S. L. Overt signs of toxicity to dogs and cats of dietary deoxynivalenol. Journal of animal Science, v. 77, p. 693-700, 1999.

HUMPHERSON-JONES, F. M. Epidemiology and control of dark leaf spot of brassicas. In: CHELKOWSKI, J.; VISCONTI, A. (Ed.). Alternaria: biology, plant diseases and metabolites. Amsterdam: Elsevier, 1992. p. 267-288.

INSTITUTO AGRONÔMICO DE CAMPINAS (IAC). Disponível em: <http://www.iac.sp.gov.br/> Acesso em: 23 mar. 2012.

INTERNATIONAL GRAINS COUNCIL (IGC). Five-year global supply and demand projections to 2017/18. Disponível em: 
<http://www.igc.int/en/downloads/grainsupdate/IGC_5year_projections.pdf> Acesso em: 10 jul. 2013.

INSTITUTO NACIONAL DE METROLOGIA, NORMALIZAÇÃO E QUALIDADE INDUSTRIAL (INMETRO). DOQ-CGCRE-008. Orientações sobre validação de métodos de ensaios químicos. Rio de Janeiro, 2003. 35 p.

JAY, J. M. Microbiologia moderna de los alimentos. 3. ed. Zaragoza: Editorial Acribia, 1994. $753 \mathrm{p}$.

JORNAL COOPERCAMPOS. Campos Novos, 17 de Abril 2009 - ANO II - Edição Nº 17. Disponível em: <http://www.copercampos.com.br/editar/arquivos/editar_jornal/2f5717456443a6659776ff2be feeb966.pdf> Acesso em: 02 nov. 2013.

JOSEPHS, R. D.; SCHUHMACHER, R.; KRSKA, R. International interlaboratory study for the determination of the Fusarium mycotoxins zearalenone and deoxynivalenol in agricultural commodities. Food Additives and Contaminants, v. 18, n. 5, p. 417-430, 2001.

JÚNIOR, G. D.; VECHIATO, M. H.; MENTEN, J. O. M. Comparação de métodos para a detecção de Fusarium graminearum em sementes de trigo (Triticum aestivum L.). Summa Phytopathologica, v. 34, n. 2, p. 164-167, 2008.

JUODEIKIENE， G.; BASINSKIENE L.; VIDMANTIENE， D.; BARTKIENE， E.; BAKUTIS, B.; BALIUKONIENE, V. Acoustic sensing of deoxynivalenol in co-occurrence with zearalenone and T-2/HT-2 toxin in winter wheat cultivar Sirvinta from Lithuania. World Mycotoxin Journal, v. 4, n. 4, p. 395-404, 2011.

KIRK, P. M.; CANNON, P. F.; MINTER, D. W.; STALPERS, J. A. Dictionary of the fungi. 10th edition. Wallinford, Oxon: CABI International, 2008.

KLITZKE, C. F. Técnicas de Ionização. Electrospray (ESI). Espectrometria de massas:

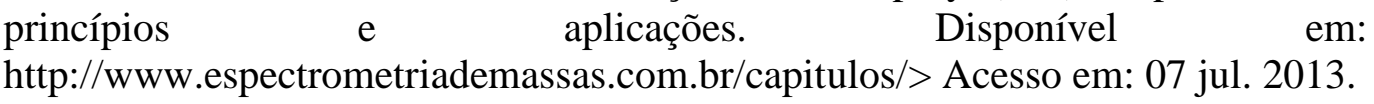

KOBAYASTI, L.; PIRES, A. P. Levantamento de fungos em sementes de trigo. Pesquisa Agropecuária Tropical, v. 41, n. 4, p. 572-578, 2011.

KOKALIS-BURELLE, N.; PORTER, D. M.; RODRIGUEZ-KABANA, R.; SMITH, D. H.; SUBRAHMANYAM, P. Compendium of peanut diseases. 2. ed. St. Paul: The American Phytopathological Society, 1997. 94 p.

KONSTANTINOVA, P.; BONANTS, P.; VAN GENT-PELZER, M.; VAN DER ZOUWEN, P.; VAN DEN BULA, R. Development of specific primers for detection and identification of Alternaria spp. in carrot material by PCR and comparison with blotter and plating assays. Mycological Research, v. 106, p. 23-33, 2002.

KOSIAK, B.; TORP, M.; SKJERVE, E.; ANDERSEN, B. Alternaria and Fusarium in Norwegian grains of reduced quality - a matched pair sample study. International Journal of Food Microbiology, v. 93, p. 51-62, 2004. 
KOSIAK, B.; TORP, M.; THRANE, U. The occurrence of Fusarium spp. in Norwegian grain - A survey. Cereal Research Communications, v. 25, p. 595-596, 1997.

KUIPER-GOODMAN, T. Prevention of human mycotoxicosis through risk assessment and risk management. In: MILLER, J. D.; TRENHOLM, H. L. (Ed.). Mycotoxins in grains. St Paul, Mn: Eagan Press, 1994. p. 439-470.

LACEY, J. Potencial hazards to animal and man from microorganisms in fodder and grain. Transactions of the British Mycological Society, v. 65, p. 171-184, 1975.

LACEY, J.; MAGAN, N. Fungi in cereal grains: their occurrence and water and temperature relationships. Developments in Food Science, v. 26, p. 77-118, 1991.

LACEY, J.; RAMAKRISHNA, N.; HAMER, A.; MAGAN, N.; MARFLEET, C. Grain fungi. In: DILIP, K.; ARORA, D. K.; MUKERJI, K. G.; MARTH, E. H. (Eds.). Handbook of Applied Mycology: foods and feeds. New York: Marcel Dekker, 1991. p. 121-77.

LAKHESAR, D. P. S.; BACKHOUSE, D.; KRISTIANSEN, P. Nutritional constraints on displacement of Fusarium pseudograminearum from cereal straw by antagonists. Biological Control, v. 55, p. 241-247, 2010.

LARGE, E. C. Growth stages in cereals illustration of the Feeks scales. Plant Pathology, v. 4, p. 22-24, 1954.

LEHMANN, L.; WAGNER, J.; METZLER, M. Estrogenic and clastogenic potential of the mycotoxin alternariol in cultured mammalian cells. Food and Chemistry Toxicology, v. 44, p. 398-408, 2006.

LEITÃO, M. F. Microbiologia de alimentos. In: ROITMAM, I.; TRAVASSOS, L. R.; AZEVEDO, J. L. (Ed.). Tratado de microbiologia. São Paulo: Manole, 1988. p. 1-81.

LESLIE, J. F.; SUMMERELL, B. A. The Fusarium laboratory manual. Lowa, Blackwell Publishing, 2006. 388 p.

LI, F.; YOSHIZAWA, T. Alternaria mycotoxins in weathered wheat from China. Journal of Agricultural and Food Chemistry, v. 48, p. 2920-2924, 2000.

LIMA, M. I. P. M. Métodos de amostragem e avaliação de giberela usados na Embrapa Trigo. Passo Fundo: Embrapa Trigo, 2002, 17 p. Disponível em: <http://www.cnpt.embrapa.br/biblio/p_do27.htm> Acesso em: 23 ago. 2012.

LIU, G.; QIAN, Y.; ZHANG, P.; DONG, W.; QI, Y.; GUO, H.T. Etiological role of Alternaria alternata in human esophageal cancer. Chinese Medical Journal, v. 105, p. 394400, 1992.

LOGRIECO, A.; BOtTAliCO, A.; MUlÉ, G.; MORETTI, A.; PERRONE, G. Epidemiology of toxigenic fungi and their associated mycotoxins for some Mediterranean crops. European Journal of Plant Pathology, v. 109, p. 645-667, 2003. 
LOGRIECO, A.; MORETTI, A.; SOLFRIZZO, M. Alternaria toxins and plant diseases: an overview of origin, occurrence and risks. World Mycotoxin Journal, v. 2, p. 129-140, 2009.

LUZ, W. C. Diagnose das doenças da cevada no Brasil. Passo Fundo, RS. Embrapa-CNPT. 1982. 24 p. (Circular Técnica, n. 2).

MACHADO, J. C. Controle de fitopatógenos associados a sementes. Informe Agropecuário, Belo Horizonte, v. 8, n. 91, p. 35-38, 1982.

MACHADO, J. C. Patologia de sementes: fundamentos e aplicações. Brasília: MEC-ESALFAEPE, 1988. $106 \mathrm{p}$.

MAGAN, N.; ALDRED, D.; MYLONA, K.; LAMBERT, R. J. W. Limiting mycotoxins in stored wheat. Food Additives and Contaminants, v. 27, n. 5, p. 644-650, 2010.

MAGAN, N.; LACEY, J. Effect of temperature and $\mathrm{pH}$ on water relations of field and storage fungi. Transactions of the British Mycological Society, v. 82, p. 71-81, 1984.

MALEKINEJAD, H.; SCHOEVERS, E. J.; DAEMEN, I. J.; ZIJLSTRA, C.; COLENBRANDER, B.; FINK-GREMMELS, J. Exposure of Oocytes to the Fusarium Toxins Zearalenone and Deoxynivalenol Causes Aneuploidy and Abnormal Embryo Development in Pigs. Biology of Reproduction, v. 77, p. 840-847, 2007.

MALLMANN, C. A.; DILKIN, P.; GIACOMINI, L. Z.; RAUBER, R. H. Critérios para seleção de um bom sequestrante para micotoxinas. In: CONFERÊNCIA APINCO 2006 DE CIÊNCIA E TECNOLOGIA AVÍCOLAS, 2006. Anais... 2006. p. 213-224.

MALLMANN. C. A.; DILKIN. P. Micotoxinas e micotoxicoses em suínos. Santa Maria: Editora Palotti, 2007. 240 p.

MANOVA, R.; MLADENOVA, R. Incidence of zearalenone and fumonisins in Bulgarian cereal production. Food Control, v. 20, p. 362-365, 2009.

MARKO, D., 2007. Mechanisms of the genotoxic effect of Alternaria toxins. In: Gesellschaft für Mykotoxin Forschung (Ed.), Proceedings of the 29th Mycotoxin Workshop. Germany: Stuttgart-Fellbach, May 14-16, 2007. p. 48.

MARINGONI, A. C. Doenças das crucíferas. In: KIMATI, H.; AMORIM, L.; BERGAMIN FILHO, A.; CAMARGO, L. E. A.; REZENDE, J. A. M. (Ed.). Manual de fitopatologia: doenças das plantas cultivadas. São Paulo: Ceres, 1997. v. 2, p. 315-324.

MARQUES, M. Validação interna dos métodos de determinação de deoxinivalenol e zearalenona por HPLC com purificação por colunas de imunoafinidade: pesquisa de deoxinivalenol e zearalenona em milhos e alimentos compostos para animais. 2007. Monografia (Licenciatura em Engenharia Química) - Departamento de Engenharia Química e Biológica, Instituto Superior Técnico, Lisboa, 2007.

MARQUES, M. F.; MARTINS, H. M.; COSTA, J. M.; BERNARDO, F. Co-occurrence of deoxynivalenol and zearalenone in crops marketed in Portugal. Food Additives and Contaminants: Part B, v. 1, n. 2, p. 130-133, 2008. 
MARTINS JÚNIOR, H. A. Estudo de determinação de resíduos de glifosato e ácido aminometilfosfônico (AMPA) em amostras de soja e água usando cromatografia líquida acoplada à espectrometria de massas em tandem com ionização por electrospray. 2005. 112 f. Dissertação (Mestrado em Ciências na Área de Tecnologia Nuclear - Materiais) - Instituto de pesquisas energéticas e nucleares - Universidade de São Paulo, São Paulo, SP, 2005.

MCMULLEN, M.; JONES, R.; GALLEMBERG, D. Scab of wheat and barley: a re-emerging disease of devastating impact. Plant Disease, v. 81, p. 1340-1348, 1997.

MELO DOS SANTOS, V.; DORNER, J. W.; CARREIRA, F. Isolation and toxigenicity of Aspergillus fumigatus from moldy silage. Mycopathologia, v. 156, p. 133-138, 2002.

MENDES, M. A. S.; SILVA, V. L.; DIANESE, J. C.; FERREIRA, M. A. S. V.; SANTOS, C. E. N.; GOMES NETO, E.; URBEN, A. F.; CASTRO, C. Fungos em plantas no Brasil. Brasília, DF: Embrapa Cenargen, 1998. 569 p.

MILLER, J. D. Fungi and mycotoxins in grains: implications for stored products research. Journal of Stored Products Research, v. 31, p. 1-16, 1995.

MIROCHA, C. J.; CHRISTENSEN, C. M. Oestrogenic mycotoxins synthesized by Fusarium. In: PURCHASE, I. F. H. (Ed.). Mycotoxins. Amsterdam: Elsevier, 1974. p. 129-148.

MONBALIU, S.; POUCKE, C. V.; DETAVERNIER, C.; DUMOULIN, F.; VAN DE VELDE, M.; SCHOETERS, E.; VAN DYCK, S.; AVERKIEVA, O.; VAN PETEGHEM, C.; SAEGER, S. Occurrence of mycotoxins in feed as analyzed by a multi-mycotoxin LCMS/MS Method. Journal of Agricultural and Food Chemistry, v. 58, p. 66-71, 2010.

MONDS, R. D.; CROMEY, G.; LAUREN, D. R.; DI MENNA, M.; MARSHALL, J. Fusarium gramineraum, $F$ cortaderiae and $F$ pseudogramineraum in New Zealand: Molecular phylogenetic analysis, mycotoxin chemotypes and co-existence of species. Mycological Research, v. 109, p. 410-420, 2005.

MONTEMURRO, N.; VISCONTI, A. Alternaria metabolites, chemical and biological data. In: CHELKOWSKI, J.; VISCONTI, A. (Ed.). Alternaria: Biology, plant diseases and metabolites. Elsevier, Amsterdam, 1992. p. 449-557.

MORGAVI, D. P.; RILEY, R. T. Fusarium and their toxins: mycology, occurrence, toxicity, control and economic impact. Animal Feed Science and Technology, v. 137, p. 199-200, 2007.

MOTTA, S.; SOARES, L. M. V. A method for the determination of two Alternaria toxins, alternariol and alternariol monomethyl ether, in tomato products. Brazilian Journal of Microbiology, v. 31, p. 315-320, 2000.

MÜLLER, H. M.; REIMANN, J.; SCHUMACHER, U.; SCHWADORF, K. Natural occurrence of Fusarium toxins in oats harvested during five years in an area of southwest Germany. Food Additives and Contaminants, v. 15, p. 801-806, 1998.

MÜLLER, M. E. H.; KORN, U. Alternaria mycotoxins in wheat e A 10 years survey in the Northeast of Germany. Food Control, v. 34, p. 191-197, 2013. 
MÜLlER, M. E. H.; STEIER, I.; KÖPPEN, R.; SIEGEL, D.; PROSKE, M.; KORN, U. Cocultivation of phytopathogenic Fusarium and Alternaria strains affects fungal growth and mycotoxin production. Journal of Applied Microbiology, v. 113, p. 874-887, 2012.

MUOTHOMI, J. W.; NDUNG'U, J. K.; GATHUMBI, J. K.; MUTITU, E. W.; WAGACHA, J.M. The occurrence of Fusarium species and mycotoxins in Kenyan wheat. Crop Protection, v. 27, p. 1215-1219, 2008.

MURRAY, G. M.; BRENNAN, J. P. Estimating disease losses to the Australian wheat industry. Australasian Plant Pathology, v. 38, p. 558-570, 2009.

NAGY, C. M.; FEJER, S. N.; BEREK, L.; MOLNAR, J.; VISKOLCZ, B. Hydrogen bondings in deoxynivalenol (DON) conformations - a density functional study. Journal of Molecular Structure, v. 726, p. 55-59, 2005.

NAKAI, V. K.; ROCHA, L. O.; GONÇALEZ, E.; FONSECA, H.; ORTEGA, E. M. M.; CORREA, B. Distribution of fungi and aflatoxins in a stored peanut variety. Food Chemistry, v. 106, n. 1, p. 285-290, 2008.

NAKATA, K.; TAKIMOTO, S. List of diseases of cultivated plants in Korea. Bulletin of Chosen Agricultural Experimental Station, v. 15, p. 1-140, 1928.

NATIONAL CENTER FOR BIOTECHNOLOGY INFORMATION. GeneBank. Disponível em: <http://blast.ncbi.nlm.nih.gov/Blast.cgi>. Acesso em: 06 jun. 2012.

NEERGAARD, P. Seed pathology. London: The MacMillan Press, 1979. v. 1, 839 p.

NELSON, P. E.; TOUSON, T. A.; MARASAS, W. F. O. Fusarium species: an illustrated manual for identification. Pennsylvania, University Press, 1983. 193 p.

NELSON. P. E. Taxonomy and biology of Fusarium moliniforme. Mycopathologia, v. 117, p. 29-36, 1992.

NETER, J.; KUTNER, M. K.; NACHTSHEIM, C. J.; WASSERMAN, W. Applied linear statistical models. 4th ed. Irwin: Chicago, 1996.

O’DONNELL, K.; KISTLER, H. C.; CIGELNIK, E.; PLOETZ, R. C. Multiple evolutionary origins of the fungus causing Panama disease of banana: Concordant evidence from nuclear and mitochondrial gene genealogies. Applied Biological Sciences, v. 94, p. 2044-2049, 1998.

O’DONNELL, K.; WARD, T. J.; GEISER, D. M.; KISTLER, H. C.; AOKI, T. Genealogical concordance between the mating type locus and seven other nuclear genes supports formal recognition of nine phylogenetically distinct species within the Fusarium graminearum clade. Fungal Genetics and Biology, v. 41, p. 600-623, 2004.

OLIVEIRA, M. S.; PRADO, G.; ABRANTES, F. M.; SANTOS, L. G.; VELOSO, T. Incidência de aflatoxinas, desoxinivalenol e zearalenona em produtos comercializados em cidades do estado de Minas Gerais no período de 1998-2000. Revista do Instituto Adolfo Lutz, v. 61, p. 1-6, 2002. 
OSBORNE, B. G. Mycotoxins and the cereal industry: a review. Journal of Food Technology, v. 17 , p. $1-9,1982$.

PANISSON, E.; REIS, E. M.; BOLLER, W. Quantificação de Danos Causados pela Giberela em Cereais de Inverno, na Safra 2000, em Passo Fundo, RS. Fitopatologia brasileira, v. 28, n. 2, 2003.

PATRIARCA, A.; AZCARATE, M. P.; TERMINIELlO, L.; PINTO, V. F. Mycotoxin production by Alternaria strains isolated from Argentinean wheat. International Journal of Food Microbiology, v. 119, p. 219-222, 2007.

PAVÓN, M. A.; GONZÁLEZ, I.; MARTÍN, R.; LACARRA, T. G. ITS-based detection and quantification of Alternaria spp. in raw and processed vegetables by real-time quantitative PCR. Food Microbiology, v. 32, p. 165-171, 2012.

PAVÓN, M. A.; GONZÁLEZ, I.; PEGELS, N.; MARTÍN, R.; GARCÍA, T. PCR detection and identification of Alternaria species-groups in processed foods based on the genetic marker Alt a 1. Food Control, v. 21, p. 1745-1756, 2010.

PERELLÓ, A. E.; MORENO, M.; SISTERNA, M. N. Alternaria infectoria species-group associated with black point of wheat in Argentina. Plant Pathology, v. 57, p. 379, 2008.

PERKOWSKI, J.; STACHOWIAK, J.; KIECANA, I.; GOLI`NSKI, P.; CHEŁKOWSKI, J. Natural occurrence of Fusarium mycotoxins in Polish cereals. Cereal Research Communications, v. 25, p. 379-380, 1997.

PESTKA, J. J. Deoxynivalenol: mechanisms of action, human exposure, and toxicological relevance. Archives of Toxicology, v. 84, p. 663-679, 2010.

PESTKA, J. J. Deoxynivalenol: Toxicity, mechanisms and animal health risks. Animal Feed Science and Technology, v. 137, p. 283-298, 2007.

PESTKA, J. J.; SMOLINSKI, T. A. Deoxynivalenol: toxicology and potential effects on humans. Journal of Toxicology and Environmental Health. Part B, v. 8, p. 39-69, 2005.

PESTKA, J. J.; ZHOU, H. R.; MOON, Y.; CHUNG, Y. J. Cellular and molecular mechanisms for immune modulation by deoxynivalenol and other trichothecenes: unraveling a paradox. Toxicology Letters, v. 153, p. 61-73, 2004.

PITT, J. I.; HOCKING, A. D. Fungi and food spoilage. 3rd ed. New York: Springer, 2009. $519 \mathrm{p}$.

PLACINTA, C. M., D’MELlO, J. P. F.; MACDONALD, A. M. C. A review of worldwide contamination of cereal grains and animal feed with Fusarium mycotoxins. Animal Feed Science and Technology, v. 78, p. 21-37, 1999.

POHLAND A. E. Mycotoxins in review. Food Additives \& Contaminants, v. 10, p. 17-28, 1993. 
POMERANZ, Y. Biochemical, functional and nutritive changes during storage. In: CHRISTENSEN, C.M. (Ed.). Storage of Cereal Grains and Their Products. $3^{\mathrm{a}}$ ed. St. Paul, Minnesota: American Association of Cereal Chemists, 1982. p. 145-217.

POZZI, C. R.; BRAGHINI, R.; ARCARO, J.; ZORZETE, P.; ISRAEL, A. L.; POZAR, I. O.; DENUCCI, S.; CORREA, B. Mycoflora and occurrence of alternariol and alternariol monomethyl ether in Brazilian sunflower from sowing to harvest. Journal of Agricultural and Food Chemistry, v. 53, p. 5824-5828, 2005.

POZZI, C. R.; CORRÊA, B.; GAMBALE, W.; PAULA, C. R.; CHACONRECHE, N. O.; MEIRELLES, M. C. A. Postharvest and stored corn in Brazil: mycoflora interation, abiotic factors and mycotoxin occurrence. Food Additives and Contaminants, v. 12, n. 3, p. 313-319. 1995.

PRIMEL, E. G. Aplicação de extração em fase solida e técnicas cromatográficas para determinação de herbicidas em águas de superfície e acompanhamento da degradação a campo e no laboratório. 2003. 170 f. Tese (Doutorado em Química Analítica) - Universidade Federal de Santa Maria, Santa Maria, 2003.

QUAGLIA, G. Ciencia y tecnología de la panificación. 2. ed. Zaragoza: Acribia, 1991. 485 p.

RAISTRICK, H.; STICKINGS, C. E.; THOMAS, R. Studies in the biochemistry of microorganisms. 90. Alternariol and alternariol monomethyl ether, metabolic products of Alternaria tenuis. Biochemistry Journal, v. 55, n. 3, p. 421-33, 1953.

RAMIREZ, L. M.; CHULZE, S.; MAGAN, N. Temperature and water activity effects on growth and temporal deoxynivalenol production by two Argentinean strains of Fusarium graminearum on irradiated wheat grain. International Journal of Food Microbiology, v. 106, p. 291-296, 2006.

RIBANI, M.; BOTTOLI, C. B. G.; COLLINS, C. H., JARDIM, I. C. S. F.; MELO, L. F. C. Validação em Métodos Cromatográficos e Eletroforéticos. Química Nova, v. 27, n. 5, p. 771$780,2004$.

RIDDELL, R. W. Permanent stained mycological preparations obtained by slid culture. Mycologia, v. 42, p. 265-270, 1950.

RIGBY, R. A.; STASINOPOULOS, D. M. Generalized additive models for location, scale and shape. Journal of the Royal Statistical Society: Series C, v. 54, n. 3, p. 507-554, 2005.

RODRIGUEZ-HERRERA, R.; WANISKA, R. D.; ROONEY, W. L. Antifungal proteins and grain mold resistance in sorghum with nonpigmented testa. Journal of Agricultural and Food Chemistry, v. 47, p. 4802-4806,1999.

ROSSETTO, C. A. V.; SILVA, O. F.; ARAÚJO, A. E. S. Influência da calagem, da época de colheita e da secagem na incidência de fungos e aflatoxinas em grãos de amendoim armazenados. Ciência Rural, v. 35, n. 2, p. 309-315, 2005.

SAMPIETRO, D. A.; MARI’N, P.; IGLESIAS, J.; PRESELLO, D. A.; VATTUONE, M. A.; CATALAN, C. A. N.; GONZALEZ JAEN, M. T. A molecular based strategy for rapid 
diagnosis of toxigenic Fusarium species associated to cereal grains from Argentina. Fungal biology, v. 114, p. 74-81, 2010.

SANCHIS, V.; MAGAN, N. Environmental conditions affecting mycotoxins. In: Mycotoxins in Food: Detection and Control (Ed.) MAGAN, N.; OLSEN, M. Oxford, UK: Woodhead Publishing Ltd, 2004. p. 174-189.

SANTIN, E. Mould growth and mycotoxin production. In: DIAZ, D. The micotoxin blue book. Nottingham, 2005. Cap. 5, p. 93-137.

SANTOS, S. M. O. Análise micológica e quantificação de zearalenona e deoxinivalenol em alimentos compostos para suínos. 2011. 148 f. Dissertação (Mestrado em Medicina Veterinária) - Universidade Lusófona de Humanidades e Tecnologias, Lisboa, 2011.

SANTOS, C. C. M.; LOPES, M. R. V.; KOSSEKI, S. Y. Ocorrência de aflatoxinas em amendoim e produtos de amendoim comercializados na região de São José de Rio Preto/SP. Revista do Instituto Adolfo Lutz, v. 60, n. 2, p. 153-157, 2001.

SCOTT, P. M. Analysis of agricultural commodities and foods for Alternaria mycotoxins. Journal of AOAC International, v. 84, p. 1809-1817, 2001.

SCOTT, P. M.; ZHAO, W.; FENG, S.; LAU, B. P. Alternaria toxins alternariol and alternariol monomethyl ether in grain foods in Canada. Mycotoxin Research, v. 28, n. 4, p. 261-266, 2012.

SCOZ, L. B.; ASTOLFI, P.; REARTES, D. S.; SCHMALE, D. G., MORAES, M. G.; DEL PONTE, E. M. Trichothecene mycotoxin genotypes of Fusarium graminearum sensu stricto and Fusarium meridionale in wheat from southern Brazil. Plant Pathology, v. 58, p. 344-351, 2009.

SECRETARIA DE AGRICULTURA, PECUÁRIA, IRRIGAÇÃO, REFORMA AGRÁRIA, PESCA E AQUICULTURA (SEAGRI). Cultura - Trigo. Disponível em: <http://www.seagri.ba.gov.br/Trigo.htm> Acesso em: 12 mar. 2012.

SIGMAALDRICH. Disponível em: www.sigmaaldrich.com. Acesso em: 12 mar. 2012.

SILLIKER, J. H.; ELLIOTT, R. P. Ecologia Microbiana de los Alimentos. Zaragoza: Acribia, 1980. p. 74-96.

SILVA, J. B.; POZZI. C. R.; MALlOZZI, M. A. B.; ORTEGA, E. M.; CORRÊA, B. Mycoflora and occurrence of Aflatoxin B1 and Fumonisin B1 during stored brazilian sorghum. Journal of Agricultural and Food Chemistry, v. 48, n. 9, p. 4352-4356, 2000.

SIMMONS, E. G. Alternaria. An identification manual. Utrecht: CBS Fungal Biodiversity Centre, 2007.

SM ALIMENTOS. Cultura: O Trigo. Disponível em: < http://www.smalimentos.com.br/site/> Acesso em: 24 jun. 2013.

SNIJDERS, C. H. A. The inheritance of resistance to head blight caused by Fusarium culmorum in winter wheat. Euphytica, v. 50, n. 1, p. 11-18, 1990. 
SOBROVA, P.; ADAM, V.; VASATKOVA, A.; BEKLOVA, M.; ZEMAN, L.; KIZEK, R. Deoxynivalenol and its toxicity. Interdisciplinary Toxicology, v. 3, n. 3, p. 94-99, 2010.

SOLEIMANY, F.; JINAP, S.; ABAS, F. Determination of mycotoxins in cereals by liquid chromatography tandem mass spectrometry. Food Chemistry, v. 130, p. 1055-1060, 2012.

SOLFRIZZO, M.; DE GIROLAMO, A.; VITTI, C.; TYLKOWSKA, K.; GRABARKIEWICZ-SZCZESNA, J.; SZOPINSKA, D.; DORNA, H. Toxigenic profile of Alternaria alternata and Alternaria radicina occurring on umbelliferous plants. Food Additives and Contaminants, v. 22, p. 302-308, 2005.

STANKOVIC, S.; LEVIC, J.; IVANOVIC, D.; KRNJAJA, V.; STANKOVIC, G.; TANCIC, $\mathrm{S}$. Fumonisin B1 and its co-occurrence with other fusariotoxins in naturally-contaminated wheat grain. Food Control, v. 23, p. 384-388, 2012.

STEYN, P. S.; VAN RENSBURG, S. J.;VAN DER WATT, J. J.; LÜBBEN A. Onyalai the possible involvement of a mycotoxin produced by Phoma sorghina in the aetiology. South African Medical Journal, 1975.

STRANDBERG, J. O. Alternaria species that attack vegetable crops: biology and options for disease management. In: CHELKOWSKI, J.; VISCONTI, A. (Ed.). Alternaria: biology, plant disease and metabolites. London: Elsevier, 1992. p.175-208.

TANAKA, M. A. S. Importância da utilização de sementes sadias. Informe Agropecuário, Belo Horizonte, v. 8, n. 91, p. 31-34, 1982.

TANAKA, M. A. S.; MACHADO, J. C. Patologia de sementes. Informe Agropecuário, Belo Horizonte, v. 11, n. 122, p. 40-46, 1985.

TANIWAKI, M. H.; SILVA, N. Fungos em alimentos: ocorrência e detecção. Campinas: ITAL, Núcleo de Microbiologia, 2001. 82 p.

THIEL, P. G.; MARASAS, W. F. O. SYDENHAM, G. S.; GELDERBLOM, W. C. A.; NIEUWENHUIS, J. J. Suevey of fumonisins production by Fusarium species. Applied and Environmental Microbiology, v. 57, p. 1089-1093, 1991.

THOMPSON, M.; ELLISON, S. L. R.; WOOD, R. Harmonized Guidelines for singlelaboratory validation of methods of analysis. Pure and Applied Chemistry, v. 74, p. 835-855, 2002.

THRANE, U.; HANSEN, U. Chemical and physiological characterization of taxa in the Fusarium sambucinum complex. Mycopathologia, v. 129, p. 183-190, 1995.

TIEMANN, U.; TOMEK, W.; SCHNEIDER, F.; MÜLLER, M.; PÖHLAND, R.; VANSELOW, J. The mycotoxins alternariol and alternariol methyl ether negatively affect progesterone synthesis in porcine granulosa cells in vitro. Toxicology Letters, v. 186, p. 139$145,2009$.

TROLLER, J. A.; BERNARD, D. T.; SCOTT, N. C. Measurement of water activity. In: SPECK, L. M. (Ed.). Compendium of Methods for the microbiological examination of foods. New York: American Public health Association, 1984. p. 124-34. 
TURNER, J. E.; JENNINGS, P. The effect of increasing humidity on Fusarium ear blight and grain quality. Cereal Research Communications, v. 25, p. 825-826, 1997.

TURNER, N. W.; SUBRAHMANYAM, S.; PILETSKY, S. A. Analytical Methods for determination of mycotoxins: A review. Analytica Chimica Acta, v. 632, p. 168-180, 2009.

TYLKOWSKA, K. Carrot seed-borne diseases caused by Alternaria species. In: CHELKOWSKI, J.; VISCONTI, A. (Eds.), Alternaria: Biology, plant diseases and metabolites. Amsterdam: Elsevier Scientific Publishers, 1992. p. 337-352.

UNITED STATES DEPARTMENT OF AGRICULTURE (USDA). World Agricultural Production. Nov, 2010 Disponível em: <http://www.pecad.fas.usda.gov/> Acesso em: 23 jul. 2011.

VEKIRU, E.; HAMETNER, C.; MITTERBAUER, R.; RECHTHALER, J.; ADAM, G.; SCHATZMAYR, G. Cleavage of Zearalenone by Trichosporon mycotoxinivorans to a Novel Nonestrogenic Metabolite. Applied and Environmental Microbiology, v. 76, n. 7, p. 23532359, 2010.

VISCONTI A.; SIBILIA A. Alternaria toxins. In: MILLER, J. D.; TRENHOLM, H. L. (Ed.). Mycotoxins in grain: compounds other than aflatoxin. St. Paul, M.N.: Eagan, 1994. p. 315336.

WAGACHA, J. M.; STEINER, U.; DEHNE, H.; ZUEHLKE, S.; SPITELLER, M.; MUTHOMI, J.; OERKE, E. Diversity in mycotoxins and fungal species infecting wheat in Nakuru District, Kenya. Journal of Phytopathology, v. 158, p. 527-535, 2010.

WARTH, B.; PARICH, A.; ATEHNKENG, J.; BANDYOPADHYAY, R.; SCHUHMACHER, R.; SULYOK, M.; KRSKA, R. Quantitation of mycotoxins in food and feed from burkina faso and Mozambique using a modern LC-MS/MS multitoxin method. Journal of Agricultural and Food Chemistry, n. 60, p. 9352-9363, 2012.

WIDESTRAND, J.; PETTERSSON, H. Effect of time, temperature and solvent on the stability of T-2 toxin, HT-2 toxin, deoxynivalenol and nivalenol calibrants. Food Additives and Contaminants, v. 18, p. 987-992, 2001.

WIKIPEDIA.

Disponível

em

<http://pt.wikipedia.org/wiki/Ficheiro:SaoPaulo_Municip_CapaoBonito.svg> Acesso em: 21 maio 2011.

WILSON, D. M.; ABRAMSON, D. Mycotoxins. In: "Storage of cereal grains and their products". American Association of Cereal Chemists. $4^{\text {th }}$ ed. St. Paul, MN: D. B. Sauer, 1992. p. 341-391.

WINDELS, C. E. Economic and social impacts of Fusarium head blight: changing farms and rural communities in the Northern Great Plains. Phytopathology, v. 90, p. 17-21, 2000.

WOODY, M. A.; CHU, F. S. Toxicology of Alternaria mycotoxins. In: CHELKOWSKI, J.; VISCONTI, A. (Ed.) Topics in secondary metabolism, v. 3, Alternaria: biology, plant Diseases and metabolites. London: Elsevier, 1992. p. 409-434. 
WU, F. Mycotoxin risk assessment for the purpose of setting international regulatory standards. Environmental Science and Technology, v. 38, p. 4049-4055, 2004.

XU, X. M.; NICHOLSON, P. Community ecology of fungal pathogens causing wheat head blight. Annual Review of Phytopathology, v. 47, p. 83-103, 2009.

ZINEDINE, A.; SORIANO, J. M.; MOLTO, J. C.; MANÊS, J. Review on the toxicity, occurrence, metabolism, detoxification, regulations and intake of zearalenone: An oestrogenic mycotoxin. Food and Chemical Toxicology, v. 45, p. 1-18, 2007.

ZORZETE, P.; REIS, T. A.; FELICIO, J. D.; BAQUIÃO, A. C.; MAKITOMO, P.; CORREA, B. Fungi, mycotoxins and phitoalexin in peanuts varieties, during plant growth in the Field, in Brazil. Food Chemistry. v. 129, p. 957-964, 2011.

ZUREIK, M.; NEULCK, C.; LEYNNART, B.; LIARD, R.; BAUSQUET, J.; NEUKIRAH, F. Sanitization to airborne mould and severity of asthma: cross sectional study from European Community respiratory health survey. British Medical Journal, v. 325, p. 411-414, 2002. 


\section{APÊNDICE A - Frequência de Isolamento Fúngico}

Tabela 12 - Frequência de isolamento de fungos, em grãos de trigo recém-colhidos nos municípios de Capão Bonito e Avaré.

\begin{tabular}{|c|c|c|c|c|c|c|}
\hline \multirow{4}{*}{ Patógenos } & \multicolumn{6}{|c|}{ Cultivar IAC 380 - Recém colhido } \\
\hline & \multicolumn{6}{|c|}{ \% Contaminação Fúngica } \\
\hline & \multicolumn{3}{|c|}{ Capão Bonito } & \multicolumn{3}{|c|}{ Avaré } \\
\hline & $\begin{array}{c}\text { Meio } \\
\text { DRBC }\end{array}$ & $\begin{array}{c}\text { Meio } \\
\text { DG } 18\end{array}$ & Média & $\begin{array}{c}\text { Meio } \\
\text { DRBC }\end{array}$ & $\begin{array}{c}\text { Meio } \\
\text { DG } 18\end{array}$ & Média \\
\hline GNC & 0,00 & 0,00 & 0,00 & 0,91 & 3,94 & 2,43 \\
\hline Alternaria spp. & 56,35 & 55,14 & 55,74 & 41,51 & 33,94 & 37,62 \\
\hline Epicoccum spp. & 9,39 & 18,18 & 13,79 & 38,00 & 27,57 & 32,79 \\
\hline Phoma spp. & 5,76 & 3,33 & 4,55 & 19,09 & 19,39 & 19,24 \\
\hline Cladosporium spp. & 2,78 & 10,30 & 6,54 & 9,39 & 28,18 & 18,79 \\
\hline Nigrospora spp. & 0,90 & 2,72 & 1,81 & 1,21 & 4,84 & 3,03 \\
\hline Drechslera spp. & 0,30 & 0,60 & 0,45 & 3,94 & 1,52 & 2,73 \\
\hline Bipolaris spp. & 1,21 & 0,90 & 1,06 & 3,50 & 1,60 & 2,55 \\
\hline Penicillium spp. & 0,60 & 0,00 & 0,30 & 0,00 & 0,61 & 0,31 \\
\hline Aspergillus spp. & 0,30 & 0,00 & 0,15 & 0,00 & 1,21 & 0,61 \\
\hline Fusarium spp. & 23,63 & 23,02 & 23,33 & 7,27 & 7,88 & 7,58 \\
\hline Acremonium spp. & 0,00 & 0,00 & 0,00 & 0,30 & 0,91 & 0,61 \\
\hline Mucor spp. & 0,00 & 0,00 & 0,00 & 0,00 & 0,61 & 0,31 \\
\hline Rhizopus spp. & 0,00 & 0,00 & 0,00 & 0,00 & 0,00 & 0,00 \\
\hline Pyrenophora spp. & 0,00 & 0,00 & 0,00 & 0,00 & 0,61 & 0,31 \\
\hline Helminthosporium spp. & 0,00 & 0,00 & 0,00 & 0,00 & 0,00 & 0,00 \\
\hline Monographella spp. & 0,30 & 0,00 & 0,15 & 0,00 & 0,00 & 0,00 \\
\hline Chaetomonium spp. & 0,00 & 0,00 & 0,00 & 0,00 & 0,00 & 0,00 \\
\hline Phomopsis spp. & 0,00 & 0,00 & 0,00 & 0,00 & 0,00 & 0,00 \\
\hline Curvularia spp. & 0,00 & 0,00 & 0,00 & 0,00 & 0,00 & 0,00 \\
\hline FNE & 0,30 & 0,30 & 0,30 & 0,00 & 0,30 & 0,15 \\
\hline
\end{tabular}

GNC: grãos não contaminados;

FNE: fungo não esporulado; 
Tabela A2 - Frequência de isolamento de fungos, em grãos de trigo dos municípios de Capão Bonito e Avaré, após 1 mês de armazenamento.

\begin{tabular}{|c|c|c|c|c|c|c|}
\hline \multirow{4}{*}{ Patógenos } & \multicolumn{6}{|c|}{ Cultivar IAC 380 - $1^{\circ}$ Mês de Armazenamento } \\
\hline & \multicolumn{6}{|c|}{ \% Contaminação Fúngica } \\
\hline & \multicolumn{3}{|c|}{ Capão Bonito } & \multicolumn{3}{|c|}{ Avaré } \\
\hline & $\begin{array}{c}\text { Meio } \\
\text { DRBC }\end{array}$ & $\begin{array}{c}\text { Meio } \\
\text { DG } 18\end{array}$ & Média & $\begin{array}{c}\text { Meio } \\
\text { DRBC }\end{array}$ & $\begin{array}{c}\text { Meio } \\
\text { DG } 18\end{array}$ & Média \\
\hline GNC & 11,52 & 21,82 & 16,67 & 7,27 & 29,69 & 18,48 \\
\hline Alternaria spp. & 45,15 & 40,60 & 42,61 & 36,36 & 34,85 & 35,65 \\
\hline Epicoccum spp. & 12,42 & 9,39 & 10,91 & 24,24 & 12,73 & 18,49 \\
\hline Phoma spp. & 7,27 & 2,42 & 4,85 & 11,82 & 11,21 & 11,52 \\
\hline Cladosporium spp. & 2,12 & 5,76 & 3,94 & 3,03 & 10,00 & 6,52 \\
\hline Nigrospora spp. & 1,21 & 3,03 & 2,12 & 0,91 & 2,12 & 1,52 \\
\hline Drechslera spp. & 0,00 & 0,61 & 0,31 & 3,40 & 1,21 & 2,31 \\
\hline Bipolaris spp. & 2,10 & 3,50 & 2,80 & 2,20 & 1,60 & 1,90 \\
\hline Penicillium spp. & 0,30 & 0,30 & 0,30 & 1,21 & 0,30 & 0,76 \\
\hline Aspergillus spp. & 0,60 & 0,91 & 0,76 & 0,91 & 0,60 & 0,76 \\
\hline Fusarium spp. & 25,50 & 21,50 & 23,75 & 7,90 & 6,97 & 7,44 \\
\hline Acremonium spp. & 0,60 & 0,00 & 0,30 & 0,00 & 0,61 & 0,31 \\
\hline Mucor spp. & 0,00 & 0,00 & 0,00 & 1,50 & 0,61 & 1,06 \\
\hline Rhizopus spp. & 0,00 & 0,00 & 0,00 & 0,00 & 0,00 & 0,00 \\
\hline Pyrenophora spp. & 1,20 & 0,00 & 0,60 & 0,00 & 0,61 & 0,31 \\
\hline Helminthosporium spp. & 0,00 & 0,00 & 0,00 & 0,90 & 0,00 & 0,45 \\
\hline Monographella spp. & 0,00 & 0,00 & 0,00 & 0,00 & 0,00 & 0,00 \\
\hline Chaetomonium spp. & 0,00 & 0,00 & 0,00 & 0,00 & 0,00 & 0,00 \\
\hline Phomopsis spp. & 0,00 & 0,00 & 0,00 & 0,00 & 0,91 & 0,46 \\
\hline Curvularia spp. & 0,60 & 0,00 & 0,30 & 1,20 & 0,00 & 0,60 \\
\hline FNE & 0,00 & 0,00 & 0,00 & 0,00 & 0,00 & 0,00 \\
\hline
\end{tabular}

GNC: grãos não contaminados;

FNE: fungo não esporulado; 
Tabela A3 - Frequência de isolamento de fungos, em grãos de trigo dos municípios de Capão Bonito e Avaré, após 2 meses de armazenamento.

\begin{tabular}{|c|c|c|c|c|c|c|}
\hline \multirow{4}{*}{ Patógenos } & \multicolumn{6}{|c|}{ Cultivar IAC 380 - $2^{\circ}$ Mês de Armazenamento } \\
\hline & \multicolumn{6}{|c|}{ \% Contaminação Fúngica } \\
\hline & \multicolumn{3}{|c|}{ Capão Bonito } & \multicolumn{3}{|c|}{ Avaré } \\
\hline & $\begin{array}{c}\text { Meio } \\
\text { DRBC }\end{array}$ & $\begin{array}{c}\text { Meio } \\
\text { DG } 18\end{array}$ & Média & $\begin{array}{c}\text { Meio } \\
\text { DRBC }\end{array}$ & $\begin{array}{c}\text { Meio } \\
\text { DG } 18\end{array}$ & Média \\
\hline GNC & 26,35 & 14,54 & 20,45 & 35,46 & 13,33 & 24,40 \\
\hline Alternaria spp. & 39,10 & 46,35 & 42,73 & 41,20 & 30,60 & 35,90 \\
\hline Epicoccum spp. & 13,33 & 14,84 & 14,09 & 9,01 & 20,00 & 14,51 \\
\hline Phoma spp. & 6,67 & 9,39 & 8,03 & 1,82 & 9,09 & 5,46 \\
\hline Cladosporium spp. & 1,52 & 6,96 & 4,24 & 0,91 & 16,06 & 8,49 \\
\hline Nigrospora spp. & 0,61 & 0,00 & 0,31 & 2,73 & 3,94 & 3,34 \\
\hline Drechslera spp. & 0,61 & 2,42 & 1,52 & 6,67 & 7,58 & 7,13 \\
\hline Bipolaris spp. & 0,60 & 1,40 & 1,00 & 0,98 & 3,80 & 2,39 \\
\hline Penicillium spp. & 1,52 & 0,00 & 0,76 & 0,91 & 0,61 & 0,76 \\
\hline Aspergillus spp. & 0,90 & 1,81 & 1,36 & 0,30 & 1,21 & 0,76 \\
\hline Fusarium spp. & 15,45 & 20,30 & 17,93 & 7,30 & 6,67 & 6,99 \\
\hline Acremonium spp. & 0,30 & 0,00 & 0,15 & 0,30 & 0,61 & 0,46 \\
\hline Mucor spp. & 0,00 & 0,00 & 0,00 & 0,00 & 0,00 & 0,00 \\
\hline Rhizopus spp. & 0,00 & 0,30 & 0,15 & 0,00 & 0,00 & 0,00 \\
\hline Pyrenophora spp. & 0,30 & 0,00 & 0,15 & 0,00 & 0,00 & 0,00 \\
\hline Helminthosporium spp. & 0,00 & 0,00 & 0,00 & 0,00 & 0,00 & 0,00 \\
\hline Monographella spp. & 1,20 & 0,00 & 0,60 & 0,00 & 0,00 & 0,00 \\
\hline Chaetomonium spp. & 0,00 & 0,00 & 0,00 & 0,00 & 0,00 & 0,00 \\
\hline Phomopsis spp. & 0,00 & 0,00 & 0,00 & 0,00 & 0,00 & 0,00 \\
\hline Curvularia spp. & 0,00 & 0,00 & 0,00 & 0,00 & 0,00 & 0,00 \\
\hline FNE & 0,30 & 0,00 & 0,15 & 0,30 & 0,00 & 0,15 \\
\hline
\end{tabular}


Tabela A4 - Frequência de isolamento de fungos, em grãos de trigo dos municípios de Capão Bonito e Avaré, após 3 meses de armazenamento.

\begin{tabular}{|c|c|c|c|c|c|c|}
\hline \multirow{4}{*}{ Patógenos } & \multicolumn{6}{|c|}{ Cultivar IAC 380 - $3^{\circ}$ Mês de Armazenamento } \\
\hline & \multicolumn{6}{|c|}{ \% Contaminação Fúngica } \\
\hline & \multicolumn{3}{|c|}{ Capão Bonito } & \multicolumn{3}{|c|}{ Avaré } \\
\hline & $\begin{array}{c}\text { Meio } \\
\text { DRBC }\end{array}$ & $\begin{array}{c}\text { Meio } \\
\text { DG } 18\end{array}$ & Média & $\begin{array}{c}\text { Meio } \\
\text { DRBC }\end{array}$ & $\begin{array}{c}\text { Meio } \\
\text { DG } 18\end{array}$ & Média \\
\hline GNC & 16,67 & 14,85 & 15,76 & 43,63 & 31,51 & 37,57 \\
\hline Alternaria spp. & 27,27 & 37,77 & 32,52 & 34,54 & 25,45 & 29,97 \\
\hline Epicoccum spp. & 16,67 & 13,33 & 15,00 & 10,30 & 14,84 & 12,57 \\
\hline Phoma spp. & 6,06 & 5,76 & 5,91 & 6,06 & 6,36 & 6,21 \\
\hline Cladosporium spp. & 2,72 & 7,27 & 5,00 & 1,21 & 3,64 & 2,43 \\
\hline Nigrospora spp. & 1,52 & 1,21 & 1,37 & 0,61 & 1,52 & 1,07 \\
\hline Drechslera spp. & 3,03 & 2,73 & 2,88 & 6,36 & 9,39 & 7,88 \\
\hline Bipolaris spp. & 0,90 & 0,56 & 0,73 & 1,20 & 0,60 & 0,90 \\
\hline Penicillium spp. & 2,12 & 0,61 & 1,37 & 1,21 & 1,52 & 1,37 \\
\hline Aspergillus spp. & 2,42 & 3,33 & 2,88 & 0,61 & 3,94 & 2,28 \\
\hline Fusarium spp. & 7,27 & 11,80 & 9,49 & 3,33 & 3,94 & 3,64 \\
\hline Acremonium spp. & 0,00 & 0,00 & 0,00 & 0,30 & 0,61 & 0,46 \\
\hline Mucor spp. & 0,00 & 0,00 & 0,00 & 0,00 & 0,00 & 0,00 \\
\hline Rhizopus spp. & 0,00 & 0,00 & 0,00 & 0,30 & 0,61 & 0,46 \\
\hline Pyrenophora spp. & 0,90 & 0,00 & 0,45 & 0,61 & 0,00 & 0,31 \\
\hline Helminthosporium spp. & 0,30 & 0,00 & 0,15 & 0,00 & 0,00 & 0,00 \\
\hline Monographella spp. & 0,00 & 0,00 & 0,00 & 0,00 & 0,00 & 0,00 \\
\hline Chaetomonium spp. & 0,00 & 0,00 & 0,00 & 0,00 & 0,00 & 0,00 \\
\hline Phomopsis spp. & 0,00 & 0,00 & 0,00 & 0,00 & 0,00 & 0,00 \\
\hline Curvularia spp. & 0,60 & 0,00 & 0,30 & 0,00 & 0,00 & 0,00 \\
\hline FNE & 0,30 & 0,60 & 0,45 & 0,30 & 0,00 & 0,15 \\
\hline
\end{tabular}

GNC: grãos não contaminados; 
Tabela A5 - Frequência de isolamento de fungos, em grãos de trigo dos municípios de Capão Bonito e Avaré, após 4 meses de armazenamento.

\begin{tabular}{|c|c|c|c|c|c|c|}
\hline \multirow{4}{*}{ Patógenos } & \multicolumn{6}{|c|}{ Cultivar IAC 380 - $4^{\circ}$ Mês de Armazenamento } \\
\hline & \multicolumn{6}{|c|}{ \% Contaminação Fúngica } \\
\hline & \multicolumn{3}{|c|}{ Capão Bonito } & \multicolumn{3}{|c|}{ Avaré } \\
\hline & $\begin{array}{c}\text { Meio } \\
\text { DRBC }\end{array}$ & $\begin{array}{c}\text { Meio } \\
\text { DG } 18\end{array}$ & Média & $\begin{array}{c}\text { Meio } \\
\text { DRBC }\end{array}$ & $\begin{array}{c}\text { Meio } \\
\text { DG } 18\end{array}$ & Média \\
\hline GNC & 41,51 & 40,91 & 41,21 & 38,77 & 34,54 & 36,66 \\
\hline Alternaria spp. & 33,34 & 32,42 & 32,88 & 24,54 & 26,36 & 25,43 \\
\hline Epicoccum spp. & 6,67 & 8,18 & 7,43 & 10,00 & 11,51 & 10,76 \\
\hline Phoma spp. & 6,67 & 8,48 & 7,58 & 5,45 & 9,09 & 7,27 \\
\hline Cladosporium spp. & 0,60 & 2,42 & 1,51 & 4,04 & 4,55 & 4,30 \\
\hline Nigrospora spp. & 1,21 & 0,91 & 1,06 & 2,12 & 1,82 & 1,97 \\
\hline Drechslera spp. & 4,84 & 2,73 & 3,79 & 6,99 & 8,48 & 7,74 \\
\hline Bipolaris spp. & 0,80 & 0,67 & 0,74 & 0,90 & 0,88 & 0,89 \\
\hline Penicillium spp. & 0,30 & 2,42 & 1,36 & 0,90 & 0,30 & 0,60 \\
\hline Aspergillus spp. & 1,21 & 3,03 & 2,12 & 0,61 & 1,20 & 0,91 \\
\hline Fusarium spp. & 6,36 & 3,94 & 5,15 & 2,72 & 1,82 & 2,27 \\
\hline Acremonium spp. & 0,61 & 0,00 & 0,31 & 0,60 & 0,30 & 0,45 \\
\hline Mucor spp. & 0,00 & 0,00 & 0,00 & 0,00 & 0,00 & 0,00 \\
\hline Rhizopus spp. & 0,00 & 0,00 & 0,00 & 0,00 & 0,00 & 0,00 \\
\hline Pyrenophora spp. & 0,00 & 0,00 & 0,00 & 0,61 & 0,61 & 0,61 \\
\hline Helminthosporium spp. & 0,00 & 0,00 & 0,00 & 0,00 & 0,00 & 0,00 \\
\hline Monographella spp. & 0,00 & 0,00 & 0,00 & 0,00 & 0,00 & 0,00 \\
\hline Chaetomonium spp. & 0,00 & 0,00 & 0,00 & 0,00 & 0,00 & 0,00 \\
\hline Phomopsis spp. & 0,00 & 0,00 & 0,00 & 0,00 & 0,00 & 0,00 \\
\hline Curvularia spp. & 0,00 & 0,00 & 0,00 & 0,00 & 0,00 & 0,00 \\
\hline FNE & 0,00 & 0,91 & 0,46 & 0,30 & 0,00 & 0,15 \\
\hline
\end{tabular}

GNC: grãos não contaminados;

FNE: fungo não esporulado; 
Tabela 13 - Frequência de isolamento de fungos, em grãos de trigo dos municípios de Capão Bonito e Avaré, após 5 meses de armazenamento.

\begin{tabular}{|c|c|c|c|c|c|c|}
\hline \multirow{4}{*}{ Patógenos } & \multicolumn{6}{|c|}{ Cultivar IAC 380 - $5^{\circ}$ Mês de Armazenamento } \\
\hline & \multicolumn{6}{|c|}{ \% Contaminação Fúngica } \\
\hline & \multicolumn{3}{|c|}{ Capão Bonito } & \multicolumn{3}{|c|}{ Avaré } \\
\hline & $\begin{array}{c}\text { Meio } \\
\text { DRBC }\end{array}$ & $\begin{array}{c}\text { Meio } \\
\text { DG } 18\end{array}$ & Média & $\begin{array}{c}\text { Meio } \\
\text { DRBC }\end{array}$ & $\begin{array}{c}\text { Meio } \\
\text { DG } 18\end{array}$ & Média \\
\hline GNC & 50,30 & 43,09 & 46,70 & 52,02 & 56,96 & 54,49 \\
\hline Alternaria spp. & 29,08 & 33,33 & 31,21 & 21,51 & 17,88 & 19,70 \\
\hline Epicoccum spp. & 7,60 & 7,27 & 7,44 & 8,50 & 8,18 & 8,34 \\
\hline Phoma spp. & 2,42 & 2,42 & 2,42 & 2,12 & 2,73 & 2,43 \\
\hline Cladosporium spp. & 0,61 & 2,73 & 1,67 & 2,36 & 3,03 & 2,70 \\
\hline Nigrospora spp. & 0,00 & 1,21 & 0,61 & 0,91 & 0,91 & 0,91 \\
\hline Drechslera spp. & 3,33 & 6,06 & 4,70 & 5,77 & 5,76 & 5,77 \\
\hline Bipolaris spp. & 0,00 & 0,60 & 0,30 & 0,45 & 0,70 & 0,58 \\
\hline Penicillium spp. & 1,21 & 1,21 & 1,21 & 1,21 & 3,94 & 2,58 \\
\hline Aspergillus spp. & 2,12 & 2,42 & 2,27 & 2,42 & 1,82 & 2,12 \\
\hline Fusarium spp. & 4,84 & 2,70 & 3,72 & 2,11 & 1,21 & 1,66 \\
\hline Acremonium spp. & 0,00 & 0,00 & 0,00 & 0,30 & 0,61 & 0,46 \\
\hline Mucor spp. & 0,00 & 0,00 & 0,00 & 0,00 & 0,30 & 0,15 \\
\hline Rhizopus spp. & 0,00 & 0,00 & 0,00 & 0,00 & 0,00 & 0,00 \\
\hline Pyrenophora spp. & 0,00 & 0,00 & 0,00 & 0,00 & 0,00 & 0,00 \\
\hline Helminthosporium spp. & 0,00 & 0,00 & 0,00 & 0,00 & 0,00 & 0,00 \\
\hline Monographella spp. & 0,00 & 0,00 & 0,00 & 0,00 & 0,00 & 0,00 \\
\hline Chaetomonium spp. & 0,00 & 0,00 & 0,00 & 0,00 & 0,00 & 0,00 \\
\hline Phomopsis spp. & 0,00 & 0,00 & 0,00 & 0,00 & 0,00 & 0,00 \\
\hline Curvularia spp. & 0,00 & 0,00 & 0,00 & 0,00 & 0,00 & 0,00 \\
\hline FNE & 0,00 & 0,00 & 0,00 & 0,91 & 0,00 & 0,46 \\
\hline
\end{tabular}


Tabela 14 - Frequência de isolamento de fungos, em grãos de trigo dos municípios de Capão Bonito e Avaré, após 6 meses de armazenamento.

\begin{tabular}{|c|c|c|c|c|c|c|}
\hline \multirow{4}{*}{ Patógenos } & \multicolumn{6}{|c|}{ Cultivar IAC 380 - $6^{\circ}$ Mês de Armazenamento } \\
\hline & \multicolumn{6}{|c|}{ \% Contaminação Fúngica } \\
\hline & \multicolumn{3}{|c|}{ Capão Bonito } & \multicolumn{3}{|c|}{ Avaré } \\
\hline & $\begin{array}{c}\text { Meio } \\
\text { DRBC }\end{array}$ & $\begin{array}{c}\text { Meio } \\
\text { DG } 18\end{array}$ & Média & $\begin{array}{c}\text { Meio } \\
\text { DRBC }\end{array}$ & $\begin{array}{c}\text { Meio } \\
\text { DG } 18\end{array}$ & Média \\
\hline GNC & 58,18 & 58,48 & 58,33 & 64,55 & 73,93 & 69,24 \\
\hline Alternaria spp. & 27,27 & 24,85 & 26,06 & 15,75 & 18,48 & 17,12 \\
\hline Epicoccum spp. & 5,45 & 6,07 & 5,76 & 4,55 & 4,85 & 4,70 \\
\hline Phoma spp. & 2,42 & 1,21 & 1,82 & 1,85 & 0,91 & 1,38 \\
\hline Cladosporium spp. & 1,52 & 2,12 & 1,82 & 2,42 & 0,00 & 1,21 \\
\hline Nigrospora spp. & 0,00 & 0,61 & 0,31 & 2,12 & 0,00 & 1,06 \\
\hline Drechslera spp. & 2,42 & 0,00 & 1,21 & 3,42 & 3,03 & 3,23 \\
\hline Bipolaris spp. & 0,30 & 0,30 & 0,30 & 0,60 & 0,00 & 0,30 \\
\hline Penicillium spp. & 0,61 & 2,42 & 1,52 & 2,73 & 0,00 & 1,37 \\
\hline Aspergillus spp. & 2,73 & 2,12 & 2,43 & 0,60 & 0,00 & 0,30 \\
\hline Fusarium spp. & 3,94 & 2,42 & 3,16 & 0,61 & 0,91 & 0,76 \\
\hline Acremonium spp. & 0,00 & 0,61 & 0,31 & 0,00 & 0,00 & 0,00 \\
\hline Mucor spp. & 0,30 & 0,30 & 0,30 & 0,00 & 0,00 & 0,00 \\
\hline Rhizopus spp. & 0,00 & 0,00 & 0,00 & 0,00 & 0,00 & 0,00 \\
\hline Pyrenophora spp. & 0,30 & 0,00 & 0,15 & 0,30 & 0,00 & 0,15 \\
\hline Helminthosporium spp. & 0,30 & 0,00 & 0,15 & 0,90 & 0,00 & 0,45 \\
\hline Monographella spp. & 0,00 & 0,00 & 0,00 & 0,00 & 0,00 & 0,00 \\
\hline Chaetomonium spp. & 0,61 & 0,00 & 0,31 & 0,00 & 0,00 & 0,00 \\
\hline Phomopsis spp. & 0,00 & 0,00 & 0,00 & 0,00 & 0,00 & 0,00 \\
\hline Curvularia spp. & 0,00 & 0,00 & 0,00 & 0,30 & 0,00 & 0,15 \\
\hline FNE & 0,00 & 0,00 & 0,00 & 0,00 & 0,00 & 0,00 \\
\hline
\end{tabular}




\section{APÊNDICE B - Curvas analíticas}

Figura B1 - Curva analítica para a quantificação de DON.

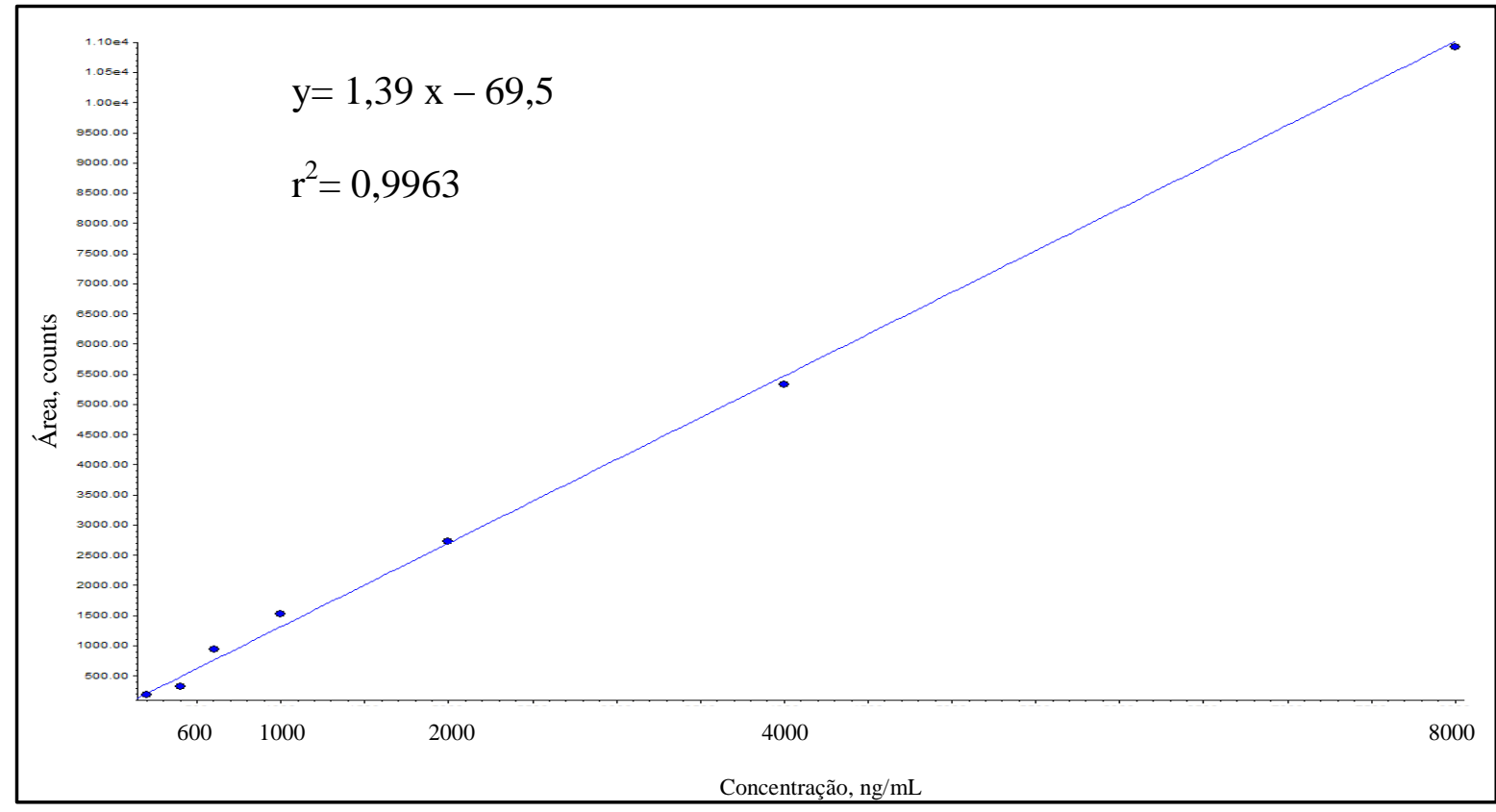

Figura B2 - Curva analítica para a quantificação de ZEA.

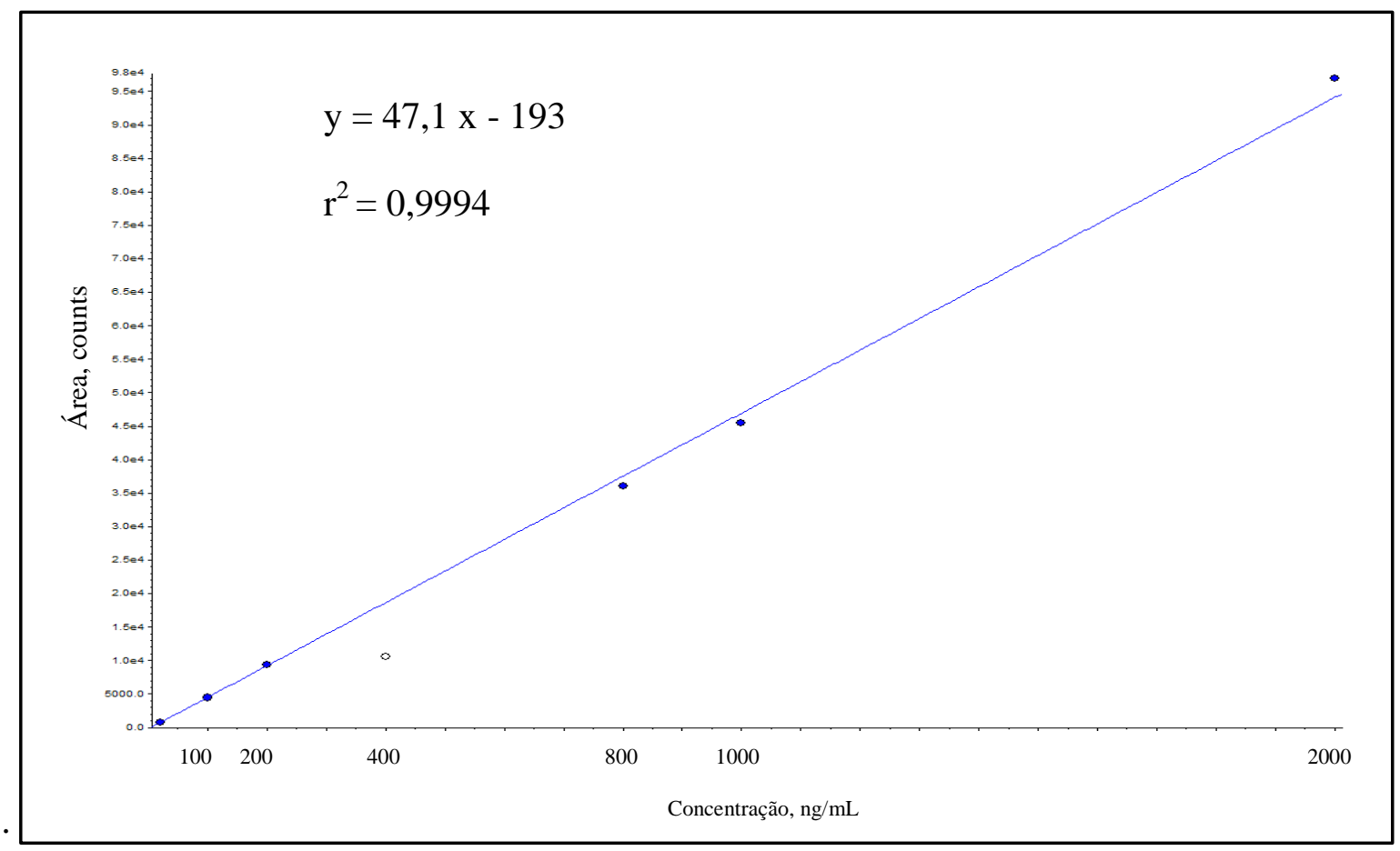


Figura B3 - Curva analítica para a quantificação de AOH.

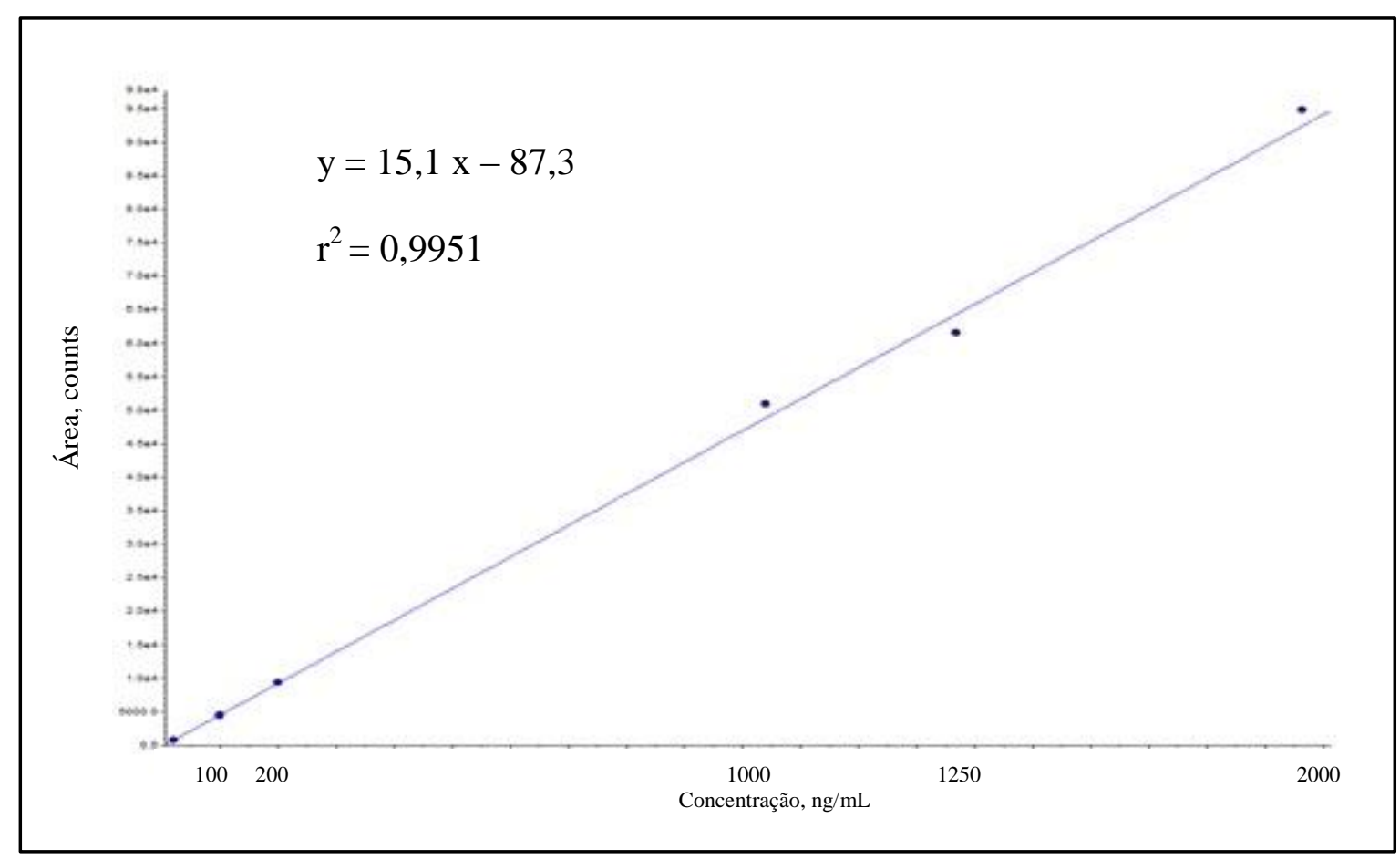




\section{APÊNDICE C - Análise Estatística}

Tabela C1 - Estatísticas descritivas para a variável crescimento de Fusarium spp.no trigo em porcentagem dos grãos contaminados (33 grãos analisados por amostra).

\begin{tabular}{|c|c|c|c|c|c|c|c|c|}
\hline Região & $\begin{array}{l}\text { Meses de } \\
\text { armazen. }\end{array}$ & $\begin{array}{l}\text { Meio de } \\
\text { cultura }\end{array}$ & Média & $\begin{array}{l}\text { Desvio } \\
\text { padrão }\end{array}$ & $\begin{array}{c}\text { Erro } \\
\text { padrão }\end{array}$ & Mínimo & Máximo & $\begin{array}{l}\% \text { de } \\
\text { zeros }\end{array}$ \\
\hline \multirow{7}{*}{ Capão } & 0 & \multirow{7}{*}{ DRBC } & 23,6 & 7,3 & 2,3 & 12,1 & 33,3 & 0,0 \\
\hline & 1 & & 25,5 & 5,0 & 1,6 & 21,2 & 36,4 & 0,0 \\
\hline & 2 & & 15,5 & 4,2 & 1,3 & 9,1 & 21,2 & 0,0 \\
\hline & 3 & & 7,3 & 4,8 & 1,5 & 0,0 & 15,2 & 10,0 \\
\hline & 4 & & 6,4 & 5,0 & 1,6 & 0,0 & 15,2 & 20,0 \\
\hline & 5 & & 4,8 & 3,8 & 1,2 & 0,0 & 12,1 & 20,0 \\
\hline & 6 & & 3,9 & 4,1 & 1,3 & 0,0 & 12,1 & 30,0 \\
\hline \multirow{7}{*}{ Avaré } & 0 & \multirow{7}{*}{ DRBC } & 7,3 & 5,0 & 1,6 & 0,0 & 18,2 & 10,0 \\
\hline & 1 & & 7,9 & 4,1 & 1,3 & 0,0 & 12,1 & 10,0 \\
\hline & 2 & & 7,3 & 4,1 & 1,3 & 0,0 & 12,1 & 10,0 \\
\hline & 3 & & 3,3 & 3,0 & 1,0 & 0,0 & 9,1 & 30,0 \\
\hline & 4 & & 2,7 & 3,0 & 1,0 & 0,0 & 9,1 & 40,0 \\
\hline & 5 & & 2,1 & 2,9 & 0,9 & 0,0 & 9,1 & 50,0 \\
\hline & 6 & & 0,6 & 1,3 & 0,4 & 0,0 & 3,0 & 80,0 \\
\hline \multirow{7}{*}{ Capão } & 0 & \multirow{7}{*}{ DG 18} & 21,2 & 10,0 & 3,2 & 0,0 & 30,3 & 10,0 \\
\hline & 1 & & 21,5 & 3,6 & 1,1 & 15,2 & 27,3 & 0,0 \\
\hline & 2 & & 20,3 & 7,8 & 2,5 & 6,1 & 33,3 & 0,0 \\
\hline & 3 & & 11,8 & 3,6 & 1,1 & 6,1 & 18,2 & 0,0 \\
\hline & 4 & & 3,9 & 3,8 & 1,2 & 0,0 & 12,1 & 30,0 \\
\hline & 5 & & 2,7 & 3,0 & 1,0 & 0,0 & 9,1 & 40,0 \\
\hline & 6 & & 2,4 & 4,0 & 1,3 & 0,0 & 12,1 & 60,0 \\
\hline \multirow{7}{*}{ Avaré } & 0 & \multirow{7}{*}{ DG 18} & 7,9 & 5,2 & 1,6 & 0,0 & 15,2 & 20,0 \\
\hline & 1 & & 7,0 & 4,1 & 1,3 & 0,0 & 12,1 & 10,0 \\
\hline & 2 & & 6,7 & 4,0 & 1,3 & 0,0 & 12,1 & 10,0 \\
\hline & 3 & & 3,9 & 4,3 & 1,4 & 0,0 & 12,1 & 40,0 \\
\hline & 4 & & 1,8 & 2,6 & 0,8 & 0,0 & 6,1 & 60,0 \\
\hline & 5 & & 1,2 & 2,1 & 0,7 & 0,0 & 6,1 & 70,0 \\
\hline & 6 & & 0,9 & 1,5 & 0,5 & 0,0 & 3,0 & 70,0 \\
\hline
\end{tabular}


Tabela C2 - Estatísticas descritivas para a variável crescimento de Alternaria spp.no trigo em porcentagem dos grãos contaminados (33 grãos analisados por amostra).

\begin{tabular}{|c|c|c|c|c|c|c|c|}
\hline Região & $\begin{array}{l}\text { Meses de } \\
\text { armazen. }\end{array}$ & $\begin{array}{l}\text { Meio de } \\
\text { cultura }\end{array}$ & Média & $\begin{array}{c}\text { Desvio } \\
\text { padrão }\end{array}$ & $\begin{array}{c}\text { Erro } \\
\text { padrão }\end{array}$ & Mínimo & Máximo \\
\hline \multirow{7}{*}{ Capão } & 0 & \multirow{7}{*}{ DRBC } & 56,4 & 7,7 & 2,4 & 39,4 & 63,6 \\
\hline & 1 & & 45,2 & 9,8 & 3,1 & 30,3 & 60,6 \\
\hline & 2 & & 39,1 & 5,0 & 1,6 & 30,3 & 45,5 \\
\hline & 3 & & 27,3 & 7,3 & 2,3 & 18,2 & 39,4 \\
\hline & 4 & & 33,3 & 4,5 & 1,4 & 27,3 & 39,4 \\
\hline & 5 & & 29,1 & 11,4 & 3,6 & 9,1 & 45,5 \\
\hline & 6 & & 27,3 & 9,1 & 2,9 & 15,2 & 42,4 \\
\hline \multirow{7}{*}{ Avaré } & 0 & \multirow{7}{*}{ DRBC } & 41,5 & 6,4 & 2,0 & 30,3 & 51,5 \\
\hline & 1 & & 36,4 & 6,7 & 2,1 & 24,2 & 45,5 \\
\hline & 2 & & 41,2 & 4,6 & 1,4 & 33,3 & 48,5 \\
\hline & 3 & & 34,5 & 9,3 & 2,9 & 21,2 & 51,5 \\
\hline & 4 & & 24,5 & 6,3 & 2,0 & 18,2 & 36,4 \\
\hline & 5 & & 21,5 & 6,1 & 1,9 & 12,1 & 27,3 \\
\hline & 6 & & 15,8 & 5,5 & 1,7 & 9,1 & 27,3 \\
\hline \multirow{7}{*}{ Capão } & 0 & \multirow{7}{*}{ DG 18} & 55,2 & 7,5 & 2,4 & 42,4 & 66,7 \\
\hline & 1 & & 40,6 & 7,6 & 2,4 & 27,3 & 48,5 \\
\hline & 2 & & 46,4 & 12,0 & 3,8 & 27,3 & 60,6 \\
\hline & 3 & & 37,9 & 8,7 & 2,8 & 21,2 & 51,5 \\
\hline & 4 & & 32,4 & 16,8 & 5,3 & 3,0 & 69,7 \\
\hline & 5 & & 33,3 & 8,8 & 2,8 & 15,2 & 45,5 \\
\hline & 6 & & 24,8 & 7,9 & 2,5 & 9,1 & 33,3 \\
\hline \multirow{7}{*}{ Avaré } & 0 & \multirow{7}{*}{ DG 18} & 33,9 & 12,6 & 4,0 & 15,2 & 51,5 \\
\hline & 1 & & 34,8 & 6,3 & 2,0 & 24,2 & 42,4 \\
\hline & 2 & & 30,6 & 6,1 & 1,9 & 21,2 & 39,4 \\
\hline & 3 & & 25,5 & 7,0 & 2,2 & 15,2 & 39,4 \\
\hline & 4 & & 26,4 & 4,1 & 1,3 & 21,2 & 33,3 \\
\hline & 5 & & 17,9 & 8,4 & 2,7 & 9,1 & 33,3 \\
\hline & 6 & & 18,5 & 5,4 & 1,7 & 12,1 & 27,3 \\
\hline
\end{tabular}


Tabela 15 - Estatísticas descritivas para a variável produção de DON em Capão Bonito em $\mu \mathrm{g} / \mathrm{Kg}$.

\begin{tabular}{cccccc}
\hline $\begin{array}{c}\text { Meses de } \\
\text { armazenamento }\end{array}$ & Média & $\begin{array}{c}\text { Desvio } \\
\text { padrão }\end{array}$ & $\begin{array}{c}\text { Erro } \\
\text { padrão }\end{array}$ & Mínimo & Máximo \\
\hline 0 & 1255 & 590 & 187 & 441 & 2470 \\
1 & 1693 & 662 & 209 & 811 & 2850 \\
2 & 1208 & 765 & 242 & 429 & 2660 \\
3 & 1319 & 502 & 159 & 581 & 2210 \\
4 & 605 & 278 & 88 & 251 & 1110 \\
5 & 331 & 124 & 39 & 210 & 566 \\
6 & 1557 & 794 & 251 & 612 & 2910 \\
\hline
\end{tabular}

Tabela C4 - Estatísticas descritivas para a variável atividade de água no trigo.

\begin{tabular}{ccccccc}
\hline Região & $\begin{array}{c}\text { Meses de } \\
\text { armazenamento }\end{array}$ & Média & $\begin{array}{c}\text { Desvio } \\
\text { padrão }\end{array}$ & $\begin{array}{c}\text { Erro } \\
\text { padrão }\end{array}$ & Mínimo & Máximo \\
\hline \multirow{4}{*}{ Capão } & 0 & 0,754 & 0,028 & 0,009 & 0,700 & 0,790 \\
& 1 & 0,672 & 0,034 & 0,011 & 0,610 & 0,720 \\
& 2 & 0,592 & 0,029 & 0,009 & 0,540 & 0,630 \\
& 3 & 0,581 & 0,019 & 0,006 & 0,560 & 0,610 \\
& 4 & 0,582 & 0,021 & 0,007 & 0,550 & 0,610 \\
& 5 & 0,543 & 0,022 & 0,007 & 0,510 & 0,570 \\
& 6 & 0,528 & 0,014 & 0,004 & 0,513 & 0,550 \\
\hline \multirow{2}{*}{ Avaré } & 0 & 0,616 & 0,033 & 0,011 & 0,570 & 0,660 \\
& 1 & 0,582 & 0,021 & 0,007 & 0,560 & 0,620 \\
& 2 & 0,577 & 0,025 & 0,008 & 0,550 & 0,620 \\
& 3 & 0,562 & 0,008 & 0,002 & 0,550 & 0,570 \\
& 4 & 0,549 & 0,021 & 0,007 & 0,521 & 0,580 \\
& 5 & 0,564 & 0,017 & 0,005 & 0,540 & 0,590 \\
& 6 & 0,541 & 0,023 & 0,007 & 0,520 & 0,590 \\
\hline
\end{tabular}


Tabela C5 - Valores médios das variáveis climatológicas nos 30 dias anteriores a cada coleta.

\begin{tabular}{|c|c|c|c|c|}
\hline \multirow{2}{*}{$\begin{array}{c}\text { Meses de } \\
\text { armazenamento }\end{array}$} & \multicolumn{2}{|c|}{ Capão } & \multicolumn{2}{|c|}{ Avaré } \\
\hline & $\begin{array}{c}\text { Precipitação } \\
(\mathbf{m m})\end{array}$ & $\begin{array}{c}\text { Temperatura } \\
\left({ }^{\circ} \mathrm{C}\right)\end{array}$ & $\begin{array}{c}\text { Precipitação } \\
\text { (mm) }\end{array}$ & $\begin{array}{c}\text { Temperatura } \\
\left({ }^{\circ} \mathrm{C}\right)\end{array}$ \\
\hline 0 & 1,22 & 20,86 & 0,23 & 20,72 \\
\hline 1 & 3,46 & 22,74 & 8,54 & 20,66 \\
\hline 2 & 5,54 & 21,83 & 3,06 & 21,43 \\
\hline 3 & 11,59 & 22,95 & 4,63 & 23,80 \\
\hline 4 & 8,73 & 23,11 & 8,87 & 22,36 \\
\hline 5 & 4,21 & 23,96 & 5,19 & 24,61 \\
\hline 6 & 5,21 & 25,03 & 1,46 & 22,61 \\
\hline
\end{tabular}

Tabela C6 - Estimativas e valores-p do ajuste do modelo de regressão binomial para a variável crescimento de Fusarium spp.

\begin{tabular}{cccccc}
\hline Variável & Nível & Estimativa & $\begin{array}{c}\text { Erro } \\
\text { padrão }\end{array}$ & Valor-p & $\begin{array}{c}\text { Exp. da } \\
\text { estimativa }\end{array}$ \\
\hline Intercepto & 1 & 0,037 & 0,110 & & \\
\hline $\begin{array}{c}\text { Meses } \\
\text { de }\end{array}$ & 2 & $-0,226$ & 0,116 & 1,037 \\
$\begin{array}{c}\text { armanamento } \\
\text { Região }\end{array}$ & 4 & $-0,942$ & 0,137 & 0,798 \\
& 5 & $-1,555$ & 0,166 & & 0,390 \\
& 6 & $-1,876$ & 0,187 & & 0,211 \\
& Capão & 1,166 & 0,087 & $<0,0001$ & 0,153 \\
\hline
\end{tabular}


Tabela 16 - Valores-p das variáveis não incluídas no modelo de regressão binomial para a variável crescimento de Fusarium spp.

\begin{tabular}{cc}
\hline Variável & Valor-p \\
\hline Meio de cultura & 0,531 \\
Atividade de água & 0,527 \\
Precipitação & 0,726 \\
Temperatura & 0,827 \\
\hline
\end{tabular}

Tabela C817 - Valores-p das comparações múltiplas no modelo de regressão binomial para a variável crescimento de Fusarium spp.

\begin{tabular}{|c|c|c|c|}
\hline \multicolumn{2}{|c|}{$\begin{array}{c}\text { Níveis de } \\
\text { comparação }\end{array}$} & \multirow{2}{*}{$\begin{array}{c}\text { Valor-p } \\
0,7403\end{array}$} & \multirow{2}{*}{$\begin{array}{c}\text { Conclusão } \\
=\end{array}$} \\
\hline 0 & 1 & & \\
\hline 1 & 2 & 0,0220 & $=$ \\
\hline 2 & 3 & $<0,0001$ & $>$ \\
\hline 3 & 4 & 0,0007 & $>$ \\
\hline 4 & 5 & 0,1492 & $=$ \\
\hline 5 & 6 & 0,1963 & $=$ \\
\hline
\end{tabular}


Tabela C9 - Estimativas e valores-p do ajuste do modelo de regressão binomial para a variável crescimento de Alternaria spp.

\begin{tabular}{|c|c|c|c|c|c|}
\hline Variável & Nível & Estimativa & $\begin{array}{c}\text { Erro } \\
\text { padrão }\end{array}$ & Valor-p & $\begin{array}{c}\text { Exp. da } \\
\text { estimativa }\end{array}$ \\
\hline Intercepto & & $-0,402$ & 0,087 & & 0,669 \\
\hline \multirow{6}{*}{$\begin{array}{c}\text { Meses } \\
\text { de } \\
\text { armazenamento }\end{array}$} & 1 & $-0,092$ & 0,114 & & 0,912 \\
\hline & 2 & $-0,078$ & 0,114 & & 0,925 \\
\hline & 3 & $-0,347$ & 0,117 & & 0,707 \\
\hline & 4 & $-0,575$ & 0,120 & & 0,563 \\
\hline & 5 & $-0,906$ & 0,127 & & 0,404 \\
\hline & 6 & $-1,078$ & 0,131 & & 0,340 \\
\hline Meio de cultura & DG 18 & $-0,200$ & 0,066 & & 0,819 \\
\hline Região & Capão & 0,593 & 0,121 & & 1,809 \\
\hline \multirow{6}{*}{$\begin{array}{l}\text { Interação meses e } \\
\text { região }\end{array}$} & 1 e Capão & $-0,427$ & 0,159 & \multirow{6}{*}{0,0029} & 0,653 \\
\hline & 2 e Capão & $-0,446$ & 0,159 & & 0,640 \\
\hline & 3 e Capão & $-0,612$ & 0,164 & & 0,542 \\
\hline & 4 e Capão & $-0,371$ & 0,166 & & 0,690 \\
\hline & 5 e Capão & $-0,116$ & 0,171 & & 0,891 \\
\hline & 6 e Capão & $-0,197$ & 0,177 & & 0,821 \\
\hline $\begin{array}{c}\text { Interação } \\
\text { cultura e região }\end{array}$ & $\begin{array}{l}\text { DG } 18 \text { e } \\
\text { Capão }\end{array}$ & 0,283 & 0,091 & 0,0018 & 1,326 \\
\hline
\end{tabular}

Tabela 18 - Valores-p das variáveis não incluídas no modelo de regressão binomial para a variável crescimento de Alternaria spp.

\begin{tabular}{cc}
\hline Variável & Valor-p \\
\hline Atividade de água & $>0,982$ \\
Precipitação em Capão & 0,587 \\
Temperatura em Capão & 0,650 \\
Precipitação em Avaré & 0,316 \\
Temperatura em Avaré & 0,064 \\
\hline
\end{tabular}


Tabela C11 - Valores-p das comparações múltiplas no modelo de regressão binomial para a variável crescimento de Alternaria spp.

\begin{tabular}{|c|c|c|c|c|c|c|}
\hline \multirow[t]{2}{*}{$\begin{array}{c}\text { Variável de } \\
\text { comparação }\end{array}$} & \multicolumn{2}{|c|}{$\begin{array}{c}\text { Níveis de } \\
\text { comparação }\end{array}$} & \multirow{2}{*}{$\begin{array}{c}\begin{array}{c}\text { Níveis var. } \\
\text { adicional }\end{array} \\
\text { Capão }\end{array}$} & \multirow{2}{*}{$\begin{array}{c}\text { Valor-p } \\
>\end{array}$} & \multirow{2}{*}{$\begin{array}{c}\begin{array}{c}\text { Valor-p } \\
\text { de referência }\end{array} \\
0,0083\end{array}$} & \multirow{2}{*}{$\begin{array}{r}\text { Conclusão } \\
<0,0001\end{array}$} \\
\hline & 0 & 1 & & & & \\
\hline \multirow{13}{*}{$\begin{array}{c}\text { Meses } \\
\text { de } \\
\text { armazenamento }\end{array}$} & 1 & 2 & Capão & $=$ & 0,0083 & 0,9563 \\
\hline & 2 & 3 & Capão & $>$ & 0,0083 & 0,0001 \\
\hline & 3 & 4 & Capão & $=$ & 0,0083 & 0,9058 \\
\hline & 4 & 5 & Capão & $=$ & 0,0083 & 0,5164 \\
\hline & 5 & 6 & Capão & $=$ & 0,0083 & 0,0383 \\
\hline & 0 & 1 & Avaré & $=$ & 0,0083 & 0,4233 \\
\hline & 1 & 2 & Avaré & $=$ & 0,0083 & 0,9092 \\
\hline & 2 & 3 & Avaré & $=$ & 0,0083 & 0,0222 \\
\hline & 3 & 4 & Avaré & $=$ & 0,0083 & 0,0647 \\
\hline & 4 & 5 & Avaré & $=$ & 0,0083 & 0,0122 \\
\hline & 5 & 6 & Avaré & $=$ & 0,0083 & 0,2268 \\
\hline & 0 & 3 & Avaré & $>$ & 0,0063 & 0,0030 \\
\hline & 3 & 6 & Avaré & $>$ & 0,0063 & $<0,0001$ \\
\hline \multirow{2}{*}{$\begin{array}{l}\text { Meio de } \\
\text { cultura }\end{array}$} & DRBC & DG18 & Capão & $=$ & 0,0250 & 0,1835 \\
\hline & DRBC & DG18 & Avaré & $>$ & 0,0250 & 0,0024 \\
\hline \multirow{14}{*}{ Região } & Capão & Avaré & DRBC t0 & $>$ & 0,0071 & $<0,0001$ \\
\hline & Capão & Avaré & DRBC $\mathrm{t} 1$ & $=$ & 0,0071 & 0,1729 \\
\hline & Capão & Avaré & $\mathrm{DRBC}$ t 2 & $=$ & 0,0071 & 0,2285 \\
\hline & Capão & Avaré & DRBC $\mathrm{t} 3$ & $=$ & 0,0071 & 0,8769 \\
\hline & Capão & Avaré & DRBC t4 & $=$ & 0,0071 & 0,0869 \\
\hline & Capão & Avaré & DRBC $\mathrm{t} 5$ & $>$ & 0,0071 & 0,0004 \\
\hline & Capão & Avaré & DRBC t6 & $>$ & 0,0071 & 0,0054 \\
\hline & Capão & Avaré & DG 18 t0 & $>$ & 0,0071 & $<0,0001$ \\
\hline & Capão & Avaré & DG $18 \mathrm{t} 1$ & $>$ & 0,0071 & 0,0002 \\
\hline & Capão & Avaré & DG $18 \mathrm{t} 2$ & $>$ & 0,0071 & 0,0004 \\
\hline & Capão & Avaré & DG $18 \mathrm{t} 3$ & $=$ & 0,0071 & 0,0390 \\
\hline & Capão & Avaré & DG $18 \mathrm{t} 4$ & $>$ & 0,0071 & 0,0001 \\
\hline & Capão & Avaré & DG 18 t5 & $>$ & 0,0071 & $<0,0001$ \\
\hline & Capão & Avaré & DG 18 t6 & $>$ & 0,0071 & $<0,0001$ \\
\hline
\end{tabular}


Tabela C12 - Estimativas e valores-p do ajuste do modelo de regressão gama para a variável produção de DON.

\begin{tabular}{cccccc}
\hline Variável & Nível & Estimativa & $\begin{array}{c}\text { Erro } \\
\text { padrão }\end{array}$ & Valor-p & $\begin{array}{c}\text { Exponencial } \\
\text { da } \\
\text { estimativa }\end{array}$ \\
\hline Intercepto & 1 & 0,300 & 0,139 & & \\
\hline $\begin{array}{c}\text { Meses } \\
\text { de }\end{array}$ & 2 & $-0,038$ & 0,139 & & 1,350 \\
armazenamento & 3 & 0,050 & 0,139 & & 0,963 \\
& 4 & $-0,729$ & 0,139 & & 1,051 \\
& 5 & $-1,332$ & 0,139 & & 0,482 \\
& 6 & 0,216 & 0,139 & & 0,264 \\
\hline
\end{tabular}

Tabela C13 - Valores-p das variáveis não incluídas no modelo de regressão gama para a variável produção de DON.

\begin{tabular}{cc}
\hline Variável & Valor-p \\
\hline Atividade de água & 0,627 \\
Fusarium spp. & 0,956 \\
Precipitação & 0,644 \\
Temperatura & 0,121 \\
\hline
\end{tabular}

Tabela C14 - Valores-p das comparações múltiplas no modelo de regressão gama para a variável produção de DON.

\begin{tabular}{cccc}
\hline \multicolumn{2}{c}{$\begin{array}{c}\text { Níveis de } \\
\text { comparação }\end{array}$} & Valor-p & Conclusão \\
\hline 0 & 1 & 0,0331 & $=$ \\
1 & 2 & 0,0166 & $=$ \\
2 & 3 & 0,5292 & $=$ \\
3 & 4 & $<0,0001$ & $>$ \\
4 & 5 & $<0,0001$ & $>$ \\
5 & 6 & $<0,0001$ & $<$ \\
\hline
\end{tabular}

